\title{
A medicalização de conflitos: consumo de ansiolíticos e antidepressivos em grupos populares
}

\author{
Reginaldo Teixeira Mendonça
}

Tese apresentada ao Programa de PósGraduação em Saúde Pública da Faculdade de Saúde Pública da Universidade de São Paulo para obtenção do título de Doutor em Saúde Pública.

Área de Concentração: Saúde MaternoInfantil

Orientador: Prof. Dr. Rubens de Camargo Ferreira Adorno

São Paulo

2009 
É expressamente proibida a comercialização deste documento tanto na sua forma impressa como eletrônica. Sua reprodução total ou parcial é permitida exclusivamente para fins acadêmicos e científicos, desde que na reprodução figure a identificação do autor, título, instituição e ano da tese. 


\section{AGRADECIMENTOS}

Primeiramente, faço um agradecimento ao CNPq (Conselho Nacional de Desenvolvimento Científico e Tecnológico) pela bolsa de doutorado.

Agradeço especialmente ao Prof. Dr. Rubens de Camargo Ferreira Adorno pelo companheirismo frente à pesquisa científica, e por ser um amigo.

Agradeço a todos os integrantes do Departamento de Saúde Materno-Infantil pela simpatia e companheirismo, em especial a Prof $f^{a}$. Dra. Maria da Penha Costa Vasconcellos. Além disso, agradeço pela amizade dos colegas de doutorado, principalmente à Ana Paula, e pelo apoio de minha família e minha companheira Jaqueline.

Tenho um agradecimento especial ao pessoal da farmácia do Centro Saúde Escola que me receberam com muita simpatia e gentileza, explicando como funcionava a farmácia. Além disso, agradeço ao pessoal do Núcleo de Saúde da Família em que estava na área de pesquisa que escolhi.

Agradeço a todos os moradores dos bairros em que pesquisei e a todas as pessoas que me receberam em suas casas.

Agradeço também ao Arquivo Público e Histórico de Ribeirão Preto por me possibilitar a consulta a seu acervo durante a realização da pesquisa de doutorado. 


\section{RESUMO}

\section{MENDONÇA, RT. A Medicalização de Conflitos: Consumo de Ansiolíticos e}

Antidepressivos em Grupos Populares. [Tese de Doutorado]. São Paulo: Faculdade de Saúde Pública da USP, 2009.

Esta pesquisa retrata uma experiência etnográfica sobre o consumo de medicamentos antidepressivos e ansiolíticos fornecidos por uma farmácia pública aos moradores de uma área formada por três bairros da cidade de Ribeirão Preto-SP. Esta área era formada por casas populares, casas luxuosas e por uma favela, sendo coberta pela Estratégia de Saúde da Família, com a exceção de uma parte das casas populares, a qual era formado pelas casas COHAB (Companhia Habitacional). $\mathrm{O}$ bairro com as casas luxuosas foi incluído somente na observação participante e na fotografia. Os motivos do consumo destes medicamentos, investigados com entrevistas abertas, observação participante, diário de campo e fotografia, são justificados através de uma remodelação e reorganização de espaços entre os moradores destes bairros, marcados por desigualdades sociais, de gênero e pela busca de diferenciação, numa hierarquia classificada entre o ideal e o indesejado através do curso de vida dos moradores. A seleção dos entrevistados foi realizada a partir dos dados da dispensação dos medicamentos psicoativos pela farmácia pública fornecedora, a qual também estava incluída na experiência etnográfica, tendo sido a dispensação dos medicamentos incluída na observação participante. $\mathrm{O}$ consumo de medicamentos psicoativos foi analisado a partir da ótica de seus consumidores, revelando que estariam contribuindo para perpetuar os papéis sociais frente à dinâmica social, como os relacionados ao gênero e à classe social. A pesquisa revela uma associação entre vida cotidiana e consumo de medicamentos psicoativos, destoante de um produzir saúde, esperado da relação entre serviços de saúde e população, e de uma associação entre doença e uso de medicamentos. Aprofundar questões sociais sobre o consumo de medicamentos em grupos populares poderá evitar seu uso abusivo com a função de produzir um corpo explorado quimicamente por se estender seus limites de produção, 
aprofundando e silenciando desigualdades sociais. O consumo de medicamentos psicoativos deve ser analisado com cautela, devendo seu consumo ser problematizado.

Palavras-chave: antropologia do medicamento, gênero, conflitos, antidepressivos, ansiolíticos, medicamentos psicoativos, grupos populares. 


\begin{abstract}
MENDONÇA, RT. The medicalization of conflict: consumption of anxiolytics and antidepressants in popular groups [Thesis]. São Paulo, Faculdade de Saúde Pública da USP, 2009.

This research shows an ethnographic experience on the use of antidepressant and anxiolytic medicines provided by a public pharmacy to the residents of an area formed by three sectors of the city of Ribeirão Preto-SP. This area was formed by popular houses, luxury houses and a shantytown, and covered by the Family Health Strategy, with the exception of part of the popular houses, which was formed by COHAB houses (Housing Company). The neighborhood with luxury houses was included only in a participant observation and in the photograph. The reasons for the use of these medicines, investigated with open interviews, participant observation, a field diary and photograph, are justified through a remodeling and reorganization of space between the residents of these neighborhoods, marked by social inequality, gender and the search for differentiation, in a classified hierarchy between the ideal and unwanted by the life's course of residents. The selection of interviewees was made from the data of the dispensing of psychoactive medicines by the provider public pharmacy, which was also included in the ethnographic experience, having been the dispensing of medicines included in participant observation. The use of psychoactive medicines has been examined from the perspective of their consumers, revealing that they were helping to perpetuate social roles in the social dynamics related to gender and social class. The research shows an association between daily life and use of psychoactive medicines, diverging from the production of health, which is waited in the relationship between health services and population, and diverging from an association between illness and medication use. Deepening social issues on the consumption of medicines in popular groups may prevent their abuse with the function of producing a body explored chemically because it has extended their limits of production, deepening and keeping quiet the social inequalities. The
\end{abstract}


consumption of psychoactive medicines should be examined with caution, their consumption should be problematized.

Key-words: anthropology of medicine, gender, conflicts, antidepressants, anxiolytics, psychoactive medicines, popular groups. 


\section{ÍNDICE}

1 APRESENTAÇÃO E OBJETIVOS 8

INTRODUÇÃO: PESQUISA SOCIAL QUALITATIVA E
MEDICAMENTOS

2.1 CONSUMO DE MEDICAMENTOS E MODELO BIOMÉDICO 13

2.2 CONSUMO DE MEDICAMENTOS COMO EXPERIÊNCIA E SUA POPULARIZAÇÃO 26

3 METODOLOGIA

4 RESULTADOS E DISCUSSÃO 51

4.1 LOCAL DA PESQUISA: A CIDADE DE RIBEIRÃO PRETO 51

4.1.1 A cidade medicalizada: serviços de saúde e consumo de medicamentos como ordenadores de espaços $\quad 58$

4.1.2 Do desenvolvimento agroindustrial ao comércio de $\begin{array}{ll}\text { produtos farmacêuticos } & 70\end{array}$

4.1.3 Medicamentos e a produção da distinção 79

4.2 FARMÁCIA PÚBLICA: AS FILAS DA MEDICALIZAÇÃO 92

4.2.1 Do público ao privado 109

4.3 CONSUMO DE MEDICAMENTOS ANTIDEPRESSIVOS E ANSIOLÍTICOS: GESTORES DE CONFLITOS 119

4.3.1 Iniciando em um campo de encruzilhadas $\quad 119$

4.3.2 Entre esquinas: lugar de julgamentos 134

4.3.3 Os espaços dos homens: das bordas ao centro do bairro antigo 160

4.3.4 Conflitos de gênero: a casa aberta à rua 179

4.3.5 Mudando de bairro, a casa dos sonhos 212

4.3.6 Aquisição da casa própria: $\mathrm{COHAB}$, a casa dos sonhos é igual a do vizinho 225

4.3.7 Quando a casa "cai": o conflito vira violência 266

5 CONSIDERAÇÕES FINAIS 276

6 REFERÊNCIAS 283

ANEXOS

Anexo 1 - Termo de Consentimento Livre e Esclarecido

296

Anexo 2 - Ofício de aprovação do projeto de pesquisa pelo Comitê de Ética em Pequisa da FSP-USP

Anexo 3 - Ofício de aprovação do projeto de pesquisa pelo Comitê de Ética em Pequisa do CSE-FMRP-USP 


\section{APRESENTAÇÃO E OBJETIVOS}

Procuro com este trabalho dar voz às concepções da população consumidora de medicamentos, contextualizando seu uso de acordo com a realidade sociocultural. Para uma problematização mais específica, escolhi dois grupos de medicamentos chamados de psicoativos: antidepressivos e ansiolíticos. Estes são medicamentos freqüentemente de uso contínuo, revelando a cronicidade dos tratamentos, apresentando um percurso que acompanha a vida das pessoas, criando itinerários terapêuticos em conjunto com esses medicamentos.

Escolhi a cidade de Ribeirão Preto, localizada no interior do Estado de São Paulo, como foco principal da análise sobre o uso de medicamentos. Como metodologia, utilizei a etnografia, como uma extensão da vivência e experiência nesta cidade, colhendo dados através de observação participante, entrevistas abertas e diário de campo. O foco da pesquisa foi analisar o consumo de medicamentos ansiolíticos e antidepressivos em moradores de regiões periféricas da cidade. Para isso, além de analisar a cidade em sua totalidade, centrei-me nos usuários desses medicamentos moradores de três bairros localizados em uma região periférica da cidade, próxima a drogarias privadas e a serviços públicos de saúde: um Núcleo de Saúde Mental, um Núcleo de Saúde da Família, um hospital de nível terciário e um Centro de Saúde com atenção secundária (lugar em que se localiza o posto de dispensação ${ }^{1}$ de medicamentos, chamado de farmácia).

1 Dispensação de medicamentos é definido por BRASIL (2001) como "o ato profissional farmacêutico de proporcionar um ou mais medicamentos a um paciente, geralmente como resposta à apresentação de uma receita elaborada por um profissional autorizado" em que o farmacêutico presta informações sobre os medicamentos, sobre seu uso considerado adequado. São destacadas informações importantes: "a ênfase no cumprimento da dosagem, a influência dos alimentos, a interação com outros medicamentos, o reconhecimento de reações adversas potenciais e as condições de conservação dos produtos." (BRASIL, 2001). 
A análise do consumo de medicamentos ansiolíticos e antidepressivos se pautou na investigação de conflitos, procurando configurar, a partir das concepções dos consumidores, os modos de uso e os porquês do consumo destes medicamentos, contextualizando o consumo de medicamentos com o cotidiano. Assim, integrei o meu dia-a-dia com os dos moradores dos bairros investigados.

O trabalho foi dividido em seis partes fundamentais: 1) consumo de medicamentos e sua ligação com pesquisas que utilizam abordagem qualitativa; 2) metodologia utilizada nesta pesquisa; 3 ) história contextualizada de Ribeirão Preto a partir dos serviços de dispensação de medicamentos; 4) o consumo de medicamentos a partir de um serviço de dispensação de medicamentos que abastece os bairros pesquisados; 5) análise dos bairros pesquisados e do consumo de medicamentos antidepressivos e ansiolíticos a partir das representações dadas pelos moradores; 6) considerações finais e apontamentos para futuras pesquisas.

A medicalização foi vista através de Ribeirão Preto, uma cidade do interior do Estado de São Paulo, marcada por seu desenvolvimento e sua transformação em pólo regional desde o início do século XX, seja pelo encontro da produção agrícola de café e sua interligação com o litoral através da estrada de ferro da Companhia Ferroviária Mojiana, seja pela encruzilhada de rodovias que a liga aos diferentes Estados, hoje se transformando em um centro de produção sucroalcooleira.

A cidade de Ribeirão Preto revela um passado ainda presente, notado através de uma arquitetura reveladora de seu passado e pelos nomes das ruas, como a Avenida do Café, que liga o centro da cidade e a rodoviária ao campus da Universidade de São Paulo (USP) e ao Hospital das Clínicas, simbolicamente um encontro entre desenvolvimento econômico e científico.

Procuro relacionar, no cotidiano de moradores de bairro populares, o consumo de medicamentos psicoativos com a presença de conflitos envolvendo os espaços internos de suas casas, o ambiente do trabalho e da rua e os conflitos decorrentes da relação entre esses espaços. Esses conflitos são permeados por diferenças e desigualdades entre grupos sociais, de gênero, intergeracionais e serviços de saúde e população. Desse modo, faço um percurso que vai desde a 
dispensação dos medicamentos até a casa de seus consumidores, contextualizando com a cidade e os bairros pesquisados.

Portanto, esta pesquisa tem como objetivo analisar o consumo de medicamentos antidepressivos e ansiolíticos a partir de sua relação com cotidiano e curso de vida de moradores de bairros populares da cidade de Ribeirão Preto. 


\section{INTRODUÇÃO: PESQUISA SOCIAL QUALITATIVA E MEDICAMENTOS}

O presente texto reflete sobre os medicamentos industrializados a partir de seus consumidores, nas diversidades de contextos socioculturais, revelando as contribuições da pesquisa social com abordagem qualitativa, entendida como experiência vivida entre pesquisador e pesquisado, elaborando um diálogo aprofundador sobre a realidade sociocultural do pesquisado ${ }^{2}$.

Procurei observar o consumo de medicamentos de forma contextualizada, a partir de interpretações diferenciadas às dadas pelos serviços de saúde, pelas prescrições médicas. O consumo de medicamentos foi visto por intermédio de sua interação com o social, pela relação entre consumidor e instituições ligadas ao campo da saúde, indo desde as pesquisas, produções de medicamentos e serviços de saúde até o uso dos medicamentos pela população.

Os estudos sobre o consumo de medicamentos geralmente se restringem aos estudos estatísticos e epidemiológicos, homogeneizando consumidores através de categorias como doença, idade, sexo, etc, não analisando particularidades do consumo e o cotidiano dos consumidores. No entanto, mostro como a pesquisa social qualitativa com medicamentos contribui para revelar estas particularidades relacionadas ao consumo dos medicamentos.

Ao unir pesquisa social e pesquisa qualitativa pode-se verificar, como GROULX (2008, p. 98), que a "pesquisa qualitativa introduz um novo sentido dos problemas; ela substitui a pesquisa dos fatores e determinantes pela compreensão dos

2 As informações contidas neste texto são contextualizadas a partir da cidade Ribeirão Preto-SP, onde fora realizada uma pesquisa de mestrado (MENDONÇA, 2005) e a presente pesquisa de doutorado. 
significados", produzindo variações que partem da comunidade e do usuário de serviços de saúde, não se concentrando no profissional e nas instituições de saúde, nos indicadores numéricos. A pesquisa social qualitativa procura, através da diversidade da vida social, destacar invisibilidades, silêncios, produzindo proximidades com o pesquisado (GROULX, 2008).

Contudo, segundo GROULX (2008), a pesquisa social, ao procurar resolver problemas sociais, pode fortalecer modelos ideológicos, não promovendo valorização e respeitabilidade às perspectivas sociais diversificadas. Assim, cautelosamente procurei, ao uni-la à pesquisa qualitativa, olhar criticamente os modelos ideológicos que estão ligados ao consumo de medicamentos e o desconhecimento destes modelos sobre os diferentes contextos socioculturais envolvidos, não fortalecendo as existentes hierarquias de poder entre serviços de saúde e população.

Estes modelos ideológicos podem acompanhar o pesquisador, impondo valores de sua classe social e concepções sobre saúde e doença, visto que a pesquisa se constitui pela interação entre pesquisado e pesquisador, pelo caminho construído no pesquisar (ADORNO, 1998). A interação pesquisador-pesquisado se forma pela criação/representação de tempos e lugares/espaços descritíveis, revelados, significantes e singulares. O pesquisado, seja individual ou social, ao se localizar no tempo e no espaço, representa seu percurso histórico-social revelador de subjetividade, que interage com a organização e estrutura social (REY, 2005).

Nesse sentido, a posição do pesquisador na estrutura social interfere na construção de seu estudo, como sua profissão (VÍCTORA e col., 2000), suas experiências vividas e subjetividades (REY, 2005). Por isso, a pesquisa qualitativa não se reduz à submissão e universalização dos instrumentos e técnicas (REY, 2005). A pesquisa se constitui como construção teórica em que o pesquisador questiona limites, possibilidades e participa da construção de seu objeto de estudo, produzindo aberturas para novos conhecimentos. Nesse sentido, vejo no medicamento objeto plural, que ao se relacionar com seu consumidor revela diversidades de questões silenciadas, ocultadas, atitudes e ações diferentes das propostas pelos serviços de 
saúde. Assim, ao adentrar em um caminho em que pacientes adquirem medicamentos antidepressivos e ansiolíticos, pude participar de uma caminhada que me pôs em alerta, ora em conflitos com o outro, ora com simpatia e concordância, produzindo um diálogo, uma intersubjetividade ao descobrir um Outro em mim e no Outro, levando-me a reelaboração de conceitos e perspectivas.

\section{1 CONSUMO DE MEDICAMENTOS E MODELO BIOMÉDICO}

Através do medicamento, modelos ideológicos se apresentam, revelando relações de poder e orientações sobre o cuidar a partir de serviços de saúde (VUCKVOVI e NICHTER, 1994; VAN DER GEEST e col., 1996). Acredita-se que esses modelos se interligam aos efeitos farmacológicos dos medicamentos, como os efeitos de sugestão decorrentes das relações prescritor/consumidor e pelas conotações promovidas pelo modelo biomédico ao provocar "verdades" e confiabilidade sobre os tratamentos, como se nota através do efeito placebo.

Inseridos aos efeitos farmacológicos dos medicamentos estão os "efeitos socioculturais" (MENDONÇA, 2005), caracterizados pelo itinerário terapêutico (desde os primeiros atos que levam ao consumo pelas pessoas, levando-as a escolher, avaliar, recusar ou aceitar) (ALVES e SOUZA,1999), (re)elaborando saberes sobre os medicamentos, desenvolvendo acordos e conflitos na presença de diferentes modos de tratamentos e substâncias medicamentosas, principalmente quando são incompatíveis ideologicamente com os modelos vigentes (como exemplo, as terapias de plantas medicinais, acupuntura, homeopáticos, etc.) (LAPLANTINE, 2004), destacando uma variedade de tratamentos questionadores do modelo biomédico vigente. 
É nessa diversidade de tratamentos que o modelo biomédico se funda, apoiado numa lógica cartesiana, objetivada e racionalizada na estatística, ignorando os saberes não incluídos nesse modelo, impondo-se como únicos verdadeiros e benéficos (OLIVEIRA, 1998a; LUZ, 2004).

Opondo-se a esta imposição, acredito que compreender e interpretar as representações sobre os medicamentos possibilita a abertura de diálogos entre população e serviço de saúde.

Nesse sentido, os medicamentos estão no ponto de interconexão entre diferentes saberes, entre o modelo biomédico representado pelo medicamento industrializado e alopático ${ }^{3}$ e outras formas de tratamento usadas pela população. Pode-se ver, de acordo com FOUCAULT (1984), que a partir do século XVIII este modelo se fundou através do corpo e passou a fazer parte de uma estratégia biopolítica: corpo observado, individualizado, racionalizado, disciplinado, normalizado através da união entre Estado e medicina. Quando se observa a evolução industrial e sua incorporação à mercantilização da Saúde e da Doença através de produtos feitos pela indústria farmacêutica, o modelo biomédico serve de apoio para subjugar tanto a Medicina quanto o Estado, principalmente quando se observa o seu consumo através de uma comunicação direta com a população, transformando a relação serviços de saúde/paciente em indústria farmacêutica/consumidores. Nesse sentido, os profissionais de saúde se distanciam do cuidar e se aproximam dos preceitos dos laboratórios farmacêuticos, restringindo-se aos efeitos dos medicamentos industrializados.

Nesse contexto, TESSER (2007) diz que os profissionais de saúde, com destaque para os médicos, passaram a dar crédito exagerado à técnica, ocorrendo o que ele chama "desresponsabilização" ética e epistemológica, o distanciamento da medicina do diálogo compartilhado com os pacientes sobre a cura, doença e saúde,

\footnotetext{
O termo alopático (ação contrária a doença, medicamento que combate a doença) está relacionado ao significado dado pela homeopatia (cura pelos semelhantes, organismo que combate a doença). O modelo biomédico adota a alopatia por se enquadrar em seus parâmetros como fragmentação do corpo, tratar a doença e não o doente como um todo, marcado por estratégia bio-política sobre a coletividade e pela produção de medicamentos em grande escala. Pode-se dizer que os medicamentos são uma espécie de especialização do modelo biomédico (LAPLANTINE, 2004).
} 
direcionando o saber médico, antes integrado à vida social, para um saber isolado nos centros de pesquisa, que homogeneiza pacientes através de dados estatísticos, centrando diálogos nas supostas verdades dos trabalhos científicos. Desse modo, os profissionais acabam reafirmando o modelo racional biomédico proposto desde a fabricação do medicamento, desconsiderando as perspectivas socioculturais. Acrescento que os profissionais de farmácia, ao reafirmarem o modelo biomédico através do medicamento, ratificam o caminho técnico em que os pacientes são submetidos desde a consulta médica. Contudo, é uma técnica que se populariza.

De acordo com BARROS (1983), o medicamento industrializado, ao se apresentar como um produto qualquer, leva os profissionais de saúde a popularizarem seu consumo, principalmente através do uso crônico. As prescrições de medicamentos e a venda nas farmácias passaram a ser, segundo este autor, momentos chaves nesta popularização. Através das prescrições médicas, o médico, além de poder racionalizar o tempo gasto nas consultas, mostra seu prestígio e poder sobre o paciente, reduzindo o tempo das consultas. Acrescento que esta mesma lógica se aplica na dispensação dos medicamentos em drogarias e farmácias, a qual se torna cada vez mais rápida e impessoal.

Analisar o medicamento industrializado a partir do modelo biomédico nos leva a contextualizar sobre questões anteriores a seu surgimento, como o nascimento da medicina social, os tratamentos para a coletividade (FOUCAULT, 1984), e o "nascimento da clínica" através da categorização de sinais e sintomas e da separação entre doença e doente durante os séculos XVII e XVIII (FOUCAULT, 1987), contribuindo para unir projeto capitalista, modelo biomédico e Estado, ao facilitar a visualização de suas interligações através de uma suposta ordem racionalizadora. Analisar os medicamentos sob esta perspectiva é também elaborar um recorte na trajetória histórica e social dos medicamentos. Como o processo de industrialização dos medicamentos se concentra a partir do século XX, manipulados pelo modelo biomédico, suas origens mais profundas são esquecidas, como a alquímica e química descritos por BACHELARD (1996). Para este autor, a racionalidade não se concretiza no pesquisar, levando o pensamento científico a buscá-la continuamente, 
revelando fracassos e esquecimentos sobre o pensar científico vinculado a subjetividade humana, às origens mágicas. Assim, como BACHELARD (1996), procuro olhar para o medicamento como um projeto racional não concluído, criando aberturas para criticá-lo e pensá-lo, evitando não olhá-lo como verdade infalível nos tratamentos de doenças. Além disso, ao ver o medicamento como objeto social, exploro a subjetividade embutida em seu consumo.

PIGNARRE (1999) diz que a descoberta de um novo medicamento envolve a anulação de qualquer subjetividade através dos testes contra-placebo. Estes testes são realizados para anular os efeitos placebos e nocebos que ocorrem durante os experimentos com seres humanos: são efeitos, que somente pelo fato de se estar tomando um suposto medicamento, já ocorrem no organismo, podendo ser danosos (nocebos) ou benéficos (placebo). Assim, possibilitariam apresentar o "verdadeiro" medicamento, aquele que "reage" por si no organismo, sem nenhuma subjetividade. Como demonstrado, na constituição ou pesquisa de medicamentos, já está anteposto o modelo racional/mecanicista, excluindo outros aspectos não contidos no modelo em questão. Com estes testes "se pretende saber se a molécula prescrita pode curar por más razões, ou seja, por razões que não se devem à sua ação farmacológicabiológica" (PIGNARRE, 1999, p. 26, grifos do autor). É através dos testes contraplacebo que os medicamentos industrializados questionam outras formas de tratamento, dizendo que somente com esta prova os verdadeiros medicamentos são produzidos.

O medicamento faz parte de um processo em que o social se comunica com o científico, criando uma polissemia diversificada pelos diferentes contextos socioculturais, pelos diferentes saberes no meio popular e acadêmico, diferentes linguagens, diferentes concepções sobre os medicamentos e sobre saúde e doença. É nesse momento que todos os testes realizados nos laboratórios em sua fabricação se dissolvem, pois é na aparência da caixa, dos comprimidos, das pomadas e nas injeções que os consumidores reais e humanos reafirmam as falhas do modelo aplicado. 
Contudo, esse caminho racionalizador é perseguido, sendo confirmado pelas formas consideradas "corretas" de consumo (maior eficácia e menores efeitos adversos possíveis: o Uso Racional de Medicamentos, uma dose certa, na hora certa e do modo certo, a um menor custo). Assim, o percurso desde o laboratório até chegar ao consumidor faz suscitar questionamentos sobre a elaboração e dispensação de medicamentos, verificando que é um caminho conflituoso, vigiado e falho ao anular a totalidade do ser humano, suas subjetividades e os diferentes contextos socioculturais. Pode-se afirmar a existência de condição autoritária e cartesiana em que se funda o modelo biomédico.

De acordo com FOUCAULT (1987), a partir do século XVIII o corpo é visto de forma fragmentada, em um processo de silenciamento do doente frente aos sinais das supostas partes doentes. É nesse contexto que diversos medicamentos vão surgir, divididos de acordo com as catalogações médicas. Assim, pode-se notar a existência de grupos farmacológicos de acordo com as partes do corpo e suas respectivas especialidades médicas (psicofármacos, gastrointestinais, imunizantes, farmacogenômico, etc), seguindo uma lógica de sub-especializações.

Através do consumo de medicamentos destacam-se estágios de desenvolvimento ou estágios de vida, idades, doenças, etapas de tratamentos, revelam-se especialidades médicas. São revelações que são trabalhadas pelo marketing dos laboratórios farmacêuticos, especificando e especializando táticas de propaganda, entrelaçando a história do paciente e do medicamento como meio de facilitação de consumo e venda, veiculando ideologias, hierarquias de poder sobre o doente (VAN DER GEEST e col., 1996). É também através do comportamento frente ao medicamento que os pacientes mostram sua realidade sociocultural, aceitando ou não o uso do medicamento, ora recebendo como objeto agradável, mágico, composto por tecnologias, ora reduzindo à cultura de consumo, colaborando no controle do corpo e a alienação social. O cuidar está freqüentemente reduzido aos produtos farmacêuticos (farmaceuticalização) (VAN DER GEEST e col., 1996), fazendo-os reafirmarem impessoalidades através de prescrições e vendas rápidas de medicamentos. 
Após a fabricação dos medicamentos há vários campos/lugares em que se pode pesquisar o medicamento. Como VAN DER GEEST e col. (1996) notam, o medicamento pronto se apresenta através da propaganda e marketing (televisão, rádio, outdoor, representantes de laboratórios, jornais e revistas científicas e populares), de sua distribuição (em hospitais, clínicas, postos de saúde, farmácias e drogarias ${ }^{4}$, entre outros), dispensados através de prescrição ou não.

As indústrias farmacêuticas produzem confrontos entre automedicação e uso através de prescrições médicas ao proporem suas propagandas incentivadoras de consumo, principalmente ao induzir o autocuidado e, conseqüentemente, a automedicação. As prescrições são na prática realizadas não só por médicos, mas outros profissionais de saúde e pessoas fora das instituições de saúde indicam ou receitam medicamentos. É conhecido nas drogarias e farmácias a ocorrência das indicações de medicamentos pelo farmacêutico e pelos balconistas. Em lugares com ausência de médico, outras pessoas ocupam o lugar de prescritor, e ocasionalmente a proximidade com os medicamentos colabora, como os donos de farmácia e drogarias (QUEIROZ, 1994).

A prescrição, ao revelar o medicamento, revela dados dos pacientes, às vezes somente pelo tipo de receita já se fazem deduções, como são as prescrições de medicamentos psicoativos que utilizam receituário especial, diferenciando-se pela cor e pelo formato de outras prescrições médicas. Na prescrição está a especialidade médica, destacada não só pelo carimbo médico, mas pela correspondência a determinados medicamentos. Além disso, as prescrições ou o consumo revelam às vezes a relação profissionais da saúde/laboratório farmacêutico. Tanto médicos quanto trabalhadores de farmácias e drogarias estão envoltos por conflitos de interesses. Os laboratórios farmacêuticos interferem tanto na prescrição médica quanto no momento em que os medicamentos são dispensados nas farmácias e

4 De acordo com BRASIL (1973), possuem conceitos diferentes: farmácia é um "estabelecimento de manipulação de fórmulas magistrais e oficinais, de comércio de drogas, medicamentos, insumos farmacêuticos e correlatos, compreendendo o de dispensação e o de atendimento privativo de unidade hospitalar ou de qualquer outra equivalente de assistência médica", enquanto drogaria é o "estabelecimento de dispensação e comércio de drogas, medicamentos, insumos farmacêuticos e correlatos em suas embalagens originais". 
drogarias. O consumo está assim direcionado para a lucratividade. É comum os balconistas e farmacêuticos oferecerem trocas de medicamentos, geralmente utilizando o preço mais baixo como forma de convencimento, mas que lhes dão maiores margens de lucros.

O profissional farmacêutico é visto como referência nas representações da população sobre os medicamentos, pois é ele que acompanha desde o processo de fabricação até a dispensação e venda. Assim, o farmacêutico se alia ao sistema capitalista ao se mostrar como vendedor nas drogarias e farmácias. São nas farmácias e drogarias que a dispensação ocorre de maneira impessoal e rápida, sendo exigida na atualidade pelos próprios clientes. Essa impessoalidade pode ser notada nas mudanças dos donos de farmácias e drogarias, sendo antes aplicado um sentido pessoal, como falar o nome da farmácia e de seu dono em seguida, ou o próprio dono ganhar em sua assinatura o nome de "farmacêutico" ou "da farmácia". É comum vermos as referências pessoais serem substituídas pelas grandes redes de farmácias e drogarias, reduzindo as relações entre dono de farmácia e cliente aos preços dos medicamentos. DUPUY e KARSENTY (1979), em pesquisa realizada na França do começo da década de 1970, já alertava sobre o uso da ciência como comércio pelo farmacêutico:

"Todos estes são princípios conformes com uma certa imagem popular do farmacêutico, notável, homem de ciência junto ao público. Devemos reconhecer que, o menos na cidade, a realidade é muito menos lisonjeira e que a profissão de farmacêutico se aproximou de modo sensível, como alguns puderam afirmar cruamente, da profissão de comerciante. Instalemo-nos em uma grande farmácia de zona urbana e observemos o que ocorre. Veremos os clientes desfilarem quase que sem interrupção. A maior parte apresenta uma receita à pessoa de bata branca que está atrás do balcão, a qual se limita a ir buscar os produtos prescritos no armário, repete a posologia indicada pelo médico, embrulha as embalagens em um saco de papel e as fatura. Poucas palavras são trocadas". (DUPUY e KARSENTY, 1979, p.47).

Há conflitos invisíveis entre laboratórios que excluem o paciente como doente e o revela como comprador, fazendo as táticas de venda das drogarias e farmácias ao utilizarem em suas portas as propagandas de menores preços, dos medicamentos a preço de custo. VAN DER GEEST e col. (1996) colocam a 
necessidade de estudos enfocados na diferença de dispensação de medicamentos no setor público e privado, informal e formal, realçando o aspecto comercial. Pode-se notar que os estudos de medicamentos não devem se reduzir a relação medicamento/ paciente, mas a relação medicamento/consumidor, pois este recorte estaria anulando analisar o medicamento como objeto social.

Nota-se que os estudos de medicamentos se concentram na relação objetivada e unidirecional, indo dos serviços de saúde à população, como se esta não tivesse autonomia. Os medicamentos se mostram plurais, fazendo parte de um processo de medicalização da sociedade em que se destaca a diversidade dos modos de uso, diferentes das normas dos serviços de saúde. O consumo se torna particularizado de acordo com o contexto sociocultural, influenciado pelo gênero, classe social, velhice, doença, saúde. Os profissionais de saúde também podem, de acordo com estas influências, induzirem o uso de medicamentos, não correspondendo a tratamentos sobre doenças, mas de concepções sobre o que supõem ser doença. Através dos medicamentos, surgem conflitos entre sociedade e os serviços de saúde, o que faz um único medicamento possuir várias representações e modos de uso.

Nesse contexto, a pesquisa social qualitativa, que enfoca consumidores de medicamentos, passa por preocupações como a definição do local e das pessoas de maneira contextualizada. O pesquisador deve ter autocrítica e reflexão sobre sua posição social, que se destaca não só por seu habitus, do modo de falar, vestir, nos gestos e gostos (THIOLLENT, 1981; BOURDIEU, 1998), mas do lugar estratégico que ele representa, como serviço de saúde e Universidade, pois os conflitos surgidos entre posição do pesquisador e do pesquisado, pelas diferenças socioculturais, precisam ser enfocados como ponto de análise e não de silenciamento. Estes conflitos podem se estender para os significados históricos dos medicamentos, do confronto entre comércio e terapêutica.

Em estudo de revisão que relaciona antropologia e consumo de medicamentos, VUCKVOVI e NICHTER (1994) concluíram que: a) os medicamentos são um veículo de ideologias, competindo com outras formas de tratamento; b) ao tomar um medicamento transformam-se concepções sobre saúde e 
doença, cuidado, revelando idéias do que é normal e desejável, entre os valores sociais e políticos impostos ao corpo (bio-política); c) as percepções dos indivíduos sobre sintomas de doença orientam o consumo de medicamentos, e muitos sintomas podem ser vistos como não medicáveis; d) o tempo de uso e a percepção sobre os efeitos dos medicamentos podem orientar o modo que se toma, aumentando ou diminuindo a dose ou recusando o uso; e) são os contextos sociais que definirão as terapias aceitas entre suas várias formas; f) questões econômicas interferem no modo de uso e na aceitação dos medicamentos.

Nesse contexto, observei em minha dissertação (MENDONÇA, 2005) que o uso de medicamentos pode ser modificado de acordo com a experiência com os tratamentos e influenciado pelas percepções dos usuários e do prescritor. Como exemplo, referi-me às concepções dos profissionais sobre a velhice, confundindo-a com doença, elevando o número de prescrições. E o tipo de doença pode também interferir no modo como os tratamentos serão seguidos, como nas doenças crônicas. A pesquisa de mestrado serviu de parâmetro para o doutorado, contribuindo para a mesma perspectiva, mas com maior aproximação com a vida cotidiana dos consumidores de medicamentos, e analisando, além dos benzodiazepínicos ou ansiolíticos, os antidepressivos, não se restringindo aos serviços de saúde, mas expandindo para o dia-a-dia dos consumidores.

Os modos de consumo são norteados de acordo com uma época em conjunto com as definições sobre o corpo, sua produção e a correspondência frente às pressões sociais. Ser disciplinado com horários de trabalho, a quantidade de trabalho, as extensões das jornadas de trabalho, o uso da automedicação como alternativa para evitar dispêndio de tempo, fixando uma produtividade mais elevada, se relacionam ao consumo de medicamentos, cujo modo não é estático, pois corresponde à dinâmica sociocultural em que estamos envolvidos. Desse modo, o percurso histórico e social de cada consumidor particulariza o modo de uso de medicamentos, destacando questões relacionadas ao gênero, à realidade socioeconômica, aos efeitos farmacológicos do medicamento, à vida cotidiana, à família, à velhice, à experiência com outros tratamentos e outros medicamentos e doenças. 
Os efeitos dos medicamentos não são farmacologicamente previsíveis, podendo serem a qualquer momento relatados efeitos que fazem com que determinados medicamentos sejam retirados do mercado, o que é reafirmado pela vigilância aos medicamentos (farmacovigilância), analisando os possíveis efeitos adversos ou qualquer problema não previstos durante os ensaios clínicos ${ }^{5}$, nos estudos sobre medicamentos. Portanto, os medicamentos passam por processo de reavaliação farmacológica quando já inseridos na sociedade. Esta, além de contextualizar os medicamentos, também avalia seus efeitos, problematizando a diversidade de contextos socioculturais e dos modos de cuidar do corpo.

Desse modo, percebo que não seria a "racionalidade" do consumidor de medicamento que estaria sendo considerada, mas sua factibilidade para seguir os preceitos do modelo biomédico. A imposição do modelo biomédico polariza os saberes populares dos acadêmicos, contribuída por desigualdades socioeconômicas em que a proximidade norteará a compreensão dos discursos (BOLTANSKI, 1984). Assim, a pesquisa social com consumidores de medicamentos procura, como OLIVEIRA (1998b) destaca através da antropologia, enxergar o Outro "de dentro", entendendo a diversidade de contextos socioculturais e respeitando-o, desvinculando olhares com ares de piedade e de fixação de subalternidades, promovendo uma interação envolvendo respeito mútuo pelas diferenças.

O consumo de medicamentos não se restringe ao tratamento de doenças, podendo corresponder à exigência de um processo de produção intensificado, ajudando a preparar o corpo para suportar as extensões dos trabalhos. Assim, os medicamentos acompanham lógicas de dominação através de representações dadas pela população, como mostrou ILLICH (1975), através da iatrogenia, o direcionamento de problemas de ordem social para os serviços de saúde, ao induzir passividade e aumento do limiar da dor e elevar a exploração capitalista e alienações sociais, fazendo o indivíduo perder sua autonomia, levando a evitar reivindicações e

5 Segundo BRASIL (2008), as pesquisas dividem seqüencialmente em pré-clínicas (realizadas com animais para medir os níveis de toxicidade) e clínicas. Estas dividem-se em: estudos de farmacologia em voluntários sadios (fase I), estudos terapêuticos ou profiláticos de exploração em pacientes (fase II) e estudos confirmatórios (fase III) e os ensaios pós-comercialização (fase IV). 
conflitos sociais. O processo saúde/doença perde significado frente a supostas categorias medicáveis, definindo tratamentos para crianças, maternidade, velhice, homens e mulheres.

Nesse contexto, GIOVANNI (1980), em pesquisa realizada no interior do Estado de São Paulo no final da década de 1970, com médicos e famílias, mostrou como o consumo de medicamentos não está diretamente relacionada ao surgimento e tratamento de doenças, mas às relações de produção capitalista. A busca de padrões de consumo produz criação de necessidades através de profissionais da saúde (como exemplo, o autor cita médicos e farmacêuticos), ao internalizar ou naturalizar o consumo de medicamentos. GIOVANNI (1980) destaca a diferença de consumo de medicamentos entre as classes sociais tanto por prescrições médicas como por automedicação, sendo esta maior entre os grupos populares e aquelas entre a população mais rica financeiramente.

Tanto a profissão médica como a farmacêutica transitam entre significados duais e com ações privilegiadas no comércio da área da saúde. As duas profissões tiveram um eixo comum em suas origens, unida em seus "pais", como o da Medicina (Hipocrátes, 450 A.C) e o da Farmácia (Galeno, 131 D.C), ambos diagnosticando e compondo remédios para dispensar. A divisão ocorreu em função do domínio do fabricar e do prescrever os medicamentos. Os farmacêuticos passaram a ter duas ações simultâneas - vender e compor - sendo freqüentemente separados, como podese observar na diferença entre drogarias, laboratórios e farmácias. De acordo com POURCHET-CAMPOS (1966), essas diferenças são marcadas na medicina quanto à aproximação com os tratamentos, como os médicos chamados de pharmaceutae que tratavam com medicamentos na/da Grécia antiga e os que tratavam com incisões cirúrgicas. Além disso, segundo esta autora, as pessoas que colhiam vegetais (rhyzotomei do grego ou herbarti do latim) se distinguiam de quem os preparavam (pharmacopoei). Além dessas referências nominais, referiam-se, segundo a autora, aos indivíduos que não eram vinculados aos médicos, como os vendedores ambulantes (circulatores e sellularii), e os que possuíam os mercados ou lojas de venda, chamados de pharmacopolei e requisitados pelos médicos (pharmaceutae). 
Assim, POURCHET-CAMPOS (1966, p. 11), além de definir um momento em que ocorre a separação entre médicos e farmacêuticos, sugere um questionamento que se responde com a observação sobre nossa sociedade: “Abrindo um parênteses, é lícito indagar: qual teria sido o real antepassado do farmacêutico: os pharmacopolei ou os pharmacopoei que antecederam cronologicamente?".

Nessa perspectiva, LOYOLA (1984), em Nova Iguaçu-RJ, identificou dois tipos de farmacêuticos em seu trabalho, o "farmacêutico-comerciante" e o "farmacêutico-terapeuta". O primeiro está voltado para o maior ganho financeiro de capital, com as farmácias localizadas na região central da cidade, com maior contato com a medicina oficial (com médicos e vários laboratórios farmacêuticos). $\mathrm{O}$ "farmacêutico-terapeuta", de acordo com LOYOLA (1984), por estar mais próximo dos grupos populares, não culpa os integrantes dessas por suas doenças, explicandoas como conseqüências das condições climáticas e, sobretudo, da má qualidade de vida relacionada às dificuldades econômicas e sociais. Além disso, o "farmacêuticoterapeuta" é visto como integrador do conhecimento científico com o popular. No entanto, segundo LOYOLA (1984), as pressões da indústria farmacêutica e o controle da saúde por órgãos públicos ou privados levam o farmacêutico-terapeuta ou tradicional a se restringir como um simples comerciante, perdendo sua função de assistente à saúde da população, fazendo com que perca seu lugar para o "farmacêutico-comerciante". Observei (MENDONÇA, 2005) que mulheres consumidoras de benzodiazepínicos viam o farmacêutico profissional como restrito à ação comercial, afirmando que nas farmácias e drogarias mais antigas promoviam maior proximidade e explicações sobre os medicamentos.

Lembro que o conceito de farmácia é diferente do conceito de drogaria. O conceito de farmácia se relaciona ao sentido de produção artesanal, o que lhe dá um sentido histórico mais longínquo, quando se diz drogarias está já relacionando ao sentido industrial do medicamento, pois nesta não há manipulação de medicamentos. GIOVANNI (1980) diz que ocorreu uma intensificação do consumo de medicamentos industrializados a partir do século XX, fazendo com que as farmácias tradicionais dessem lugar às modernas drogarias, muitas sem um farmacêutico. 
Assim, o medicamento feito pela pessoa do farmacêutico passou a ser representado por uma indústria ou laboratório. Segundo PIGNARRE (1999), o preparador de medicamentos já não está submisso às requisições médicas, ele serve ao grande complexo industrial.

Estudar o medicamento pela confluência de saberes significa unir ciências, não separando o biológico do social e do cultural, colocando o objeto de estudo medicamento como interdisciplinar (híbrido) (SEVALHO, 2003), localizando/percorrendo caminhos desde sua fabricação e sua relação com os consumidores, o que se pode definir como uma espécie de trajeto sócio-antropofarmacológico. A pesquisa social qualitativa com consumidores de medicamentos envolve este trajeto, o que faz do pesquisador o formador de um cômpito, ponto de interconexão histórico-social entre pesquisador, medicamentos e seus consumidores. Desse modo, o consumo de medicamentos é visto como construção sociocultural, fazendo a união de saberes, anulando barreiras entre sociedade e ciência, não reduzindo o seu consumo a questões imediatas como o tratamento de doentes. Podese verificar que muitos tratamentos são transformados pelos laboratórios farmacêuticos em medicamentos, com nomes alheios à população antes conhecedora do remédio, agora transformado em medicamento com marca, nome científico, nome genérico e, muitas vezes, patenteados (OLIVEIRA, 1998a).

Vale lembrar que os medicamentos também possuem um percurso desde a sua primeira fabricação e descoberta. As pesquisas que deram origem aos benzodiazepínicos na década de 1950 resultaram na mudança de tratamentos para diversas doenças e orientaram um mercado consumidor via serviços de saúde que não previa os efeitos colaterais desses medicamentos com seu uso crônico, como a dependência (MENDONÇA, 2005). Os antidepressivos seguem o mesmo caminho, sendo os primeiros medicamentos inventados também na década de 1950, sendo a depressão naquela época ainda considerada um problema raro, chegando seus fabricantes a duvidarem de uma boa projeção comercial do primeiro antidepressivo, a imipramina, contudo, atualmente os antidepressivos estão entre os medicamentos mais prescritos em todo o mundo, com destaque para a fluoxetina, considerada a 
“droga da felicidade” (AGUIAR, 2004). Antidepressivos e ansiolíticos possuem acelerado crescimento do consumo, levando a estarem entre os medicamentos mais consumidos na atualidade. Sua inserção no mercado e a busca de novos medicamentos dessas classes foram sendo ampliados, assim como seu mercado consumidor. Paralelamente ao caminho que os medicamentos percorrem no organismo, ocorre um trajeto sócio-histórico dos mesmos que revela diferentes discursos do usuário, do prescritor, do cuidador, do dispensador. Pesquisar medicamentos é também analisar esses percursos.

\subsection{CONSUMO DE MEDICAMENTOS COMO EXPERIÊNCIA E SUA POPULARIZAÇÃO}

Os medicamentos, além de estarem relacionados aos tratamentos e prevenções de doenças no âmbito social, são inseridos em microcosmos, de experiências particulares, individuais, familiares, dos diferentes grupos sociais. Podese compreender os sentidos dados aos medicamentos comparando os significados dados à palavra "doença" em inglês - illness, disease, sickness - descritos por KLEINMAN (1988). De acordo com este autor, o médico transforma o que o paciente diz em termos técnicos, assim como os pacientes também traduzem os termos médicos para a sua própria linguagem e contexto social. A doença (disease), para os médicos, é descrita através de seu aprendizado acadêmico, formal, técnico, enquanto a doença (illness) para o paciente refere ou categoriza seus sintomas e incapacidades de acordo com o contexto sociocultural, tornando explicável para o grupo social ao qual pertence. Nesse sentido, o paciente transforma disease em illness e o médico transforma illness em disease. Além desses dois termos, a doença, quando ganha conotação social, é vista como sickness, quando a doença se apresenta no plano macrossocial (político, econômico e institucional), isto é, compartilhada e 
organizada tanto pelo médico como pelo paciente. Entre os significados dados à doença está o medicamento, ora procurando objetivá-la, ora subjetivando-a, dependendo das imposições ideológicas e relações de poder.

Através do medicamento a doença se socializa (VAN DER GEEST e WHYTE, 2003), se concretiza em illness e sickness. Os medicamentos contribuem para a explicação/compreensão da doença e suas causas. Assim, muitos pacientes começam a explanar sobre suas doenças a partir dos medicamentos que usam ou usaram, ou, quando não querem revelá-la, são ausentados da percepção (exemplo, doenças com conotações sociais moralizantes e com preconceitos). De acordo com VAN DER GEEST e WHYTE (2003), esta situação leva muitos medicamentos a se tornarem popularizados (como exemplo, citam os antibióticos utilizados contra doenças venéreas, sendo dissimulados pelo usuário, mas propagados pela coletividade).

Alguns medicamentos podem tanto ser popularizados através de uma relação de poder, de conhecimento do consumidor, como de silêncio quando querem evitar estereótipos ou estigmas. Notei (MENDONÇA, 2005) que os calmantes benzodiazepínicos, além de serem indicados e emprestados a vizinhos, amigos e parentes, são também escondidos de vizinhos e dos patrões por medo dos preconceitos oriundos do uso desses medicamentos. Não é incomum ver nos consultórios médicos os pacientes abaixarem o tom de voz quando tratam de algumas doenças que possuem relação moral ou com a honra. Nas drogarias e farmácias notase que o pedido de informação sobre tratamentos ou de medicamentos, muitos já popularizados, para a automedicação, ocorre às vezes por vergonha de irem ao médico. Nessa perspectiva, é possível ver pessoas pedindo medicamentos ginecológicos e para impotência, hemorróidas, contracepção, entre outros, de forma sigilosa, nas drogarias e farmácias. Pode-se acrescentar o medo de irem ao médico ou a disponibilidade de tempo, devido às pressões do trabalho, à dedicação ao acúmulo financeiro, às pressões de parceiros ou familiares (BOLTANSKI, 1984).

$\mathrm{O}$ consumo de medicamentos industrializados se popularizou e se contextualizou após as descobertas dos antibióticos no século XX, sendo marcado 
por imposição etnocêntrica sobre outras terapias (VAN DER GEEST e WHYTE, 2003). Os pacientes exigem a prescrição ao profissional médico, servindo como parâmetro para avaliação, e os médicos que não prescrevem medicamentos podem ser vistos com desconfiança. Os tratamentos se fixam assim através de medicamentos industrializados, marcados pelas grandes corporações industriais. Nota-se que os efeitos colaterais dos medicamentos são pouco enfatizados frentes aos efeitos terapêuticos, principalmente quando não são notados sintomaticamente pelo consumidor, como a dependência medicamentosa e a facilitação de outras doenças com o uso crônico.

As concepções sobre os medicamentos, interferindo no modo como serão utilizados, acompanham noções simbólicas como a cor do comprimido ou de líquidos, a aparência da embalagem, na apresentação, a condição de ser um lançamento, entre outros. FERREIRA (1998) relata que os anticoncepcionais podem ser vistos como uma espécie de barreira mecânica, os anti-hipertensivos quando associados a diuréticos são considerados bons para os rins por fazer urinar, confundese quantidade com qualidade do tratamento, as injeções por provocarem dor são consideradas melhores do que comprimidos e xaropes, a coloração é confundida com eficácia. Lembro que estas preferências são transformadas em lucratividade nas farmácias e drogarias. Pode-se citar o exemplo das injeções, que ao possuírem efeitos relativamente mais rápidos quando comparadas aos comprimidos, fazendo os sintomas do cliente desaparecerem em um menor tempo, colaboram para a fama das drogarias que as indicam ou dos médicos prescritores.

Lembro de alguns diálogos existentes com clientes mais idosos sobre as injeções e sua popularização, como a existência de curiosos, que tinham em suas casas seringas para aplicarem em seus conhecidos, muitas vezes usadas como símbolo de poder, de um conhecimento que provoca distinção. Essa situação se revela pela concorrência pelo mercado entre as drogarias e farmácias e outros profissionais ligados à saúde com médicos, religiosos (QUEIROZ, 1994). Não se pode descartar os esquecimentos, a compreensão de que já tomou o suficiente, mesmo sendo diferente do prescrito, seja por considerar nocivo à saúde, por se 
sentirem melhor, por desconfiarem do tratamento, ou por não quererem se mostrar doentes. O medicamento envolve série de ações singulares voltadas para a terapêutica tanto no âmbito popular como nos serviços de saúde oficializados.

A disease pode levar o medicamento prescrito pelos serviços de saúde como individualizado enquanto sickness, ao ser conhecida socialmente, também populariza os tratamentos medicamentosos relacionados, como os medicamentos para gripes, resfriados, difundidos no cotidiano. Dentro das farmácias e drogarias ocorrem as diferenciações entre disease e sickness. Alguns medicamentos como os psicoativos (psicotrópicos) são comprados somente com receita médica, mas outros medicamentos, que deveriam ser vendidos somente com a apresentação de receita médica, os de tarja vermelha, são popularmente vendidos livremente nas farmácias e drogarias, sendo geralmente indicados entre a população. Outros medicamentos, acompanhando esta lógica, são os de venda livre, ficando geralmente expostos para os compradores para livremente pegarem (como exemplo, em comparação como os de venda com prescrição médica, os chamados medicamentos éticos, existem os chamados OTCs - Over the Counter - como alguns fortificantes, alguns produtos fitoterápicos, antiácidos, purgantes, antitérmicos, colírios). É bom lembrar que todos esses medicamentos possuem efeitos colaterais. As farmácias e drogarias fazem assim analogias referentes à sua gestão e localização em seus espaços ao que é individual e ao coletivo, ao público e ao privado, ao fechado e ao aberto.

Essas analogias também são encontradas no espaço doméstico. $\mathrm{O}$ uso do medicamento é manipulado pela vida cotidiana, podendo se relacionar ao espaço doméstico e ao público, ao individual e ao coletivo, seguindo uma lógica cultural (FAINZANG, 2003). De acordo com esta autora, em sua pesquisa realizada na França, o medicamento não se restringe ao doente, interagindo com os outros moradores do lar. O medicamento pode ser gerenciado por uma percepção através do espaço social em que os pacientes se encontram. Por um lado, quando o medicamento é visto por uma perspectiva coletiva, ele é indicado aos outros membros da família, sugerindo que compre na farmácia ou que o médico receite e, mesmo durante as consultas, acompanhantes de pacientes podem contribuir para a 
popularização de tratamentos medicamentosos. Por outro lado, na gestão individual do medicamento, os pacientes restringem-se ao diálogo com o médico. Os medicamentos são adaptados dentro de uma lógica individual e coletiva, aceitando ou recusando o uso de acordo com a prescrição médica, sendo interferida pelas concepções sobre o medicamento, a saúde e a doença (FAINZANG, 2003).

FAINZANG (2003) mostra como os medicamentos são organizados no espaço doméstico, sendo administrados, indicados, conservados, guardados. A autora notou que os protestantes franceses, possuindo uma lógica mais individualizada na gestão do medicamento, os guardavam em espaços mais reservados, como o quarto de dormir. Enquanto, os católicos franceses centrados em uma lógica mais coletiva, guardavam seus medicamentos em lugares em que toda a família tinha acesso, como o banheiro e cozinha. A autora ainda destaca que os medicamentos são separados por pessoas e também por doenças, sendo divididos em caixas, sacos, sacolas, gavetas. A casa se transforma numa extensão do corpo, dentro de seu próprio espaço privado, do espaço doméstico, ocorrendo uma divisão mais íntima, mais privada e organizando os medicamentos segundo as concepções de seus moradores, indo do espaço mais íntimo ao mais familiar ou coletivo da casa, existindo uma analogia, no plano simbólico, entre o corpo e a casa, sendo o medicamento intermediário entre estes espaços.

O lugar de guardar os medicamentos pode também estar relacionado à estrutura da família, como exemplo, guardar os medicamentos em cima da geladeira, facilitando o lembrar para tomá-los e para evitar que crianças não consigam pegá-los, ou mesmo, guardados dentro de armários fechados quando não mais os utilizam. E quando se tem uma pessoa acamada, muitos medicamentos ficam junto à cama do doente.

As drogarias e farmácias acompanham esta mesma lógica, ocorrendo divisões entre os medicamentos, os de venda livre na área externa ao balcão, a que os clientes têm fácil acesso, e os de venda controlada em prateleiras atrás do balcão ou, no caso dos medicamentos psicoativos, em armários fechados com chave. Na compra de um medicamento, este pode ser personificado, colaborando para sua divisão no espaço 
doméstico, sendo etiquetados com símbolos pela farmácia ou drogaria ou escritos o nome do usuário e o modo de uso na embalagem do medicamento pelos funcionários da farmácia ou drogaria. Também, além de variar o estoque de acordo com a doença, ele é aumentado de acordo com sua gravidade, fazendo um vaivém constante aos serviços de saúde e à farmácia ou à drogaria.

Em se tratando de uma sociedade que vê no medicamento o principal meio para a cura de suas doenças, as concepções sobre estes podem interferir no modo de seu uso. Contudo, essas concepções são trabalhadas pelos comerciantes de medicamentos, como nas drogarias, relacionando essas concepções a suas lucratividades, suprindo as carências farmacológicas dos clientes. Podem acontecer diferentes mecanismos lucrativos, como a venda de medicamentos sem exigência de prescrições médicas, como as vitaminas, os fortificantes, alguns medicamentos para dor, etc. Não é incomum pessoas, ao sentirem sintomas de doença ou mal-estares, irem às drogarias e voltarem com vários medicamentos, preenchendo os espaços vazios das caixas e gavetas. Nota-se que muitos doentes crônicos, por já terem experiências com diversos tratamentos, procuram diretamente as drogarias, sem passar por avaliações médicas.

Lembro que na venda de medicamentos pode ocorrer divisão de acordo com a classe social do cliente, enfatizando a separação entre medicamentos considerados similares, genéricos e de referência. De acordo com BRASIL (1999), esta divisão se refere à igualdade de substâncias ou princípio ativo, concentração, forma de apresentação, via de administração, modo de usar, indicação, servindo de parâmetro para os similares e genéricos o medicamento de referência (medicamento inovador com eficácia, segurança e qualidade comprovada cientificamente), devendo o genérico ser equivalente quantitativo e qualitativamente relativo à absorção e eliminação da substância no organismo humano, tendo em sua identificação a denominação do princípio ativo em lugar do nome de fantasia, possuindo embalagens padronizadas para serem identificados.

No entanto, quando se trata de sua relação com o mercado consumidor, notase várias diferenças: os similares se apresentam como mais baratos para os clientes, 
mas geralmente dão aos vendedores maiores lucros por serem comprados com preços bem inferiores aos de venda, sendo geralmente dadas aos balconistas comissões sobre a venda destes medicamentos (GIOVANNI, 1980). Devido ao baixo custo, esses medicamentos são comprados por governantes e distribuídos para a população, incentivando a sua compra quando necessária.

Nesse sentido, a compra de um medicamento pode às vezes se restringir ao preço e não à qualidade, dependendo do capital cultural e econômico (BOLTANSKI, 1984): um paciente rico, com plano de saúde privado, geralmente com capital cultural e econômico que contribuirá para o encontro de linguagens afins com um serviço de saúde em que o médico prescreverá um medicamento de marca (referência), o qual será exigido na hora da compra. A negociação com o cliente de grupos populares muitas vezes ocorre pelo preço, o vendedor de medicamentos vem logo com o mais barato, um medicamento similar, dizendo que "é igual ao outro e bem mais barato, o mesmo efeito", fazendo permuta das prescrições médicas ou indicando diretamente aos clientes.

Pude verificar que na cidade de Ribeirão Preto-SP as diferenças entre classes sociais estão co-relacionadas com os estoques de medicamentos e a estrutura física das drogarias. As drogarias dos bairros populares, além de possuírem relativamente em seus estoques uma maior concentração de medicamentos similares, possuem estrutura mais simples quando comparadas às drogarias do centro da cidade, que possuem climatização com ar condicionado, balança eletrônica, maiores estoques de medicamentos de referência. As drogarias periféricas se aproximam dos postos públicos de dispensação quanto aos estoques de similares.

O consumo de medicamentos está relacionado com desde as propagandas feitas pela indústria farmacêutica, pelos profissionais e serviços de saúde até as relações pessoais do dia-a-dia, fazendo o contexto cultural colaborar com a aceitação ou recusa dos medicamentos. Cultura pode ser compreendida a partir dos estudos de GEERTZ (1989), definindo-a como sistema dinâmico simbólico, construída pelo ser humano à medida que é também construído por ela, colaborando para interpretar e ser interpretado. Nesse sentido, a cultura é compreendida através do aprofundamento, 
somente depois de inserido nessa dinâmica que se pode interpretar os significados culturais de gestos, de ações, modos de comportar, etc. Assim, GEERTZ (1989) estabelece cultura como uma teia que faz e se prende a ela, identificando e permitindo aos indivíduos e a determinado grupo interpretar suas experiências e coordenar suas ações. O consumo de medicamentos alcança conflitos interculturais, como o ocorrido entre população indígena e não indígena, sendo o medicamento objeto de poder que produz diferenças e encontros interculturais contextualizados pelo local, crença e valores, emergindo conflitos, recusas e aceitações do medicamento (DIEHL e RECH, 2004). As noções sobre tratamentos são variáveis, seguindo diferentes interpretações de acordo com o contexto sociocultural, como as definições de doença que devem buscar um tratamento médico ou um tratamento de uma benzedeira (OLIVEIRA, 1998a). LAPLANTINE (2004) evidencia modelos históricos e popularizados de interpretar os tratamentos: os tratamentos mágicoreligiosos, o uso de adição ou subtração de substâncias, os tratamentos que procuram “ensinar" o organismo a se defender (exemplo, homeopatia), os que se resumem à relação substância/doença (exemplo, alopatia), os tratamentos que procuram acalmar ou sedar e outros que são concebidos como excitativos.

Nesse sentido, o consumo de medicamentos é visto como construção sociocultural, sendo avaliado e interpretado à medida que é inserido na sociedade. $\mathrm{O}$ medicamento é compreendido de maneira particular pelos diferentes atores e grupos sociais, envolvendo conflitos entre concepções quando imposto de forma autoritária, principalmente frente à existência de diversidade de tratamentos de doenças. De acordo com LANGDON (1996), a doença é vista como uma experiência heterogênea: é interpretada de diferentes formas pelas pessoas que circunvizinham o doente e o que pode ser doença para uma cultura não é para outra. LANGDON (1996) nos diz que o processo terapêutico não é um simples consenso, constitui-se através de seqüência de decisões e negociações, pois os sintomas e sinais da doença são ambíguos. As experiências com doença são refletidas como poder que contribui nas escolhas de tratamentos. Os usuários mais antigos de determinados medicamentos prestam conselhos e respondem aos questionamentos de futuros 
consumidores. Acrescenta-se que os profissionais considerados mais experientes, com maior tempo de serviço e titulação acadêmica, podem ser preferidos pelos consumidores ou pacientes.

A partir da pesquisa social qualitativa se exerce uma postura relativista, partindo dos consumidores, suas representações sobre os medicamentos, evitando um etnocentrismo acadêmico e autoritário frente à diversidade de medicamentos e interpretações existentes na sociedade. Compreender o consumo nos diferentes contextos socioculturais é analisar respostas a este etnocentrismo, que procura racionalizar e normatizar comportamentos e atitudes referentes aos medicamentos. Assim, mesmo reféns de um olhar, de um ouvir (feito da interação, interlocução, do diálogo entre pesquisador e pesquisado), já academicamente disciplinado, mas que (a)nota diferenças, semelhanças, conflitos e faz o cotidiano ressurgir como expressão sociocultural frente a sua diversidade de contextos (OLIVEIRA, 1998b) em que consumidores de medicamentos estão envoltos, a relação pesquisador-pesquisado pode criar um "ambiente" de análise em que se inclui autocrítica frente às diferenças.

Segundo OLIVEIRA (1998b), as observações reveladas na escrita do pesquisador são influenciadas pela posição que ocupa (acadêmico e social), por isso, o ver o outro a partir de interações com o pesquisador deve ser questionado ou problematizado no interpretar e no compreender das anotações e observações, que ganham sentido a partir da memória do pesquisador durante a escrita. É através desta que se revelam maneiras de pensar e agir diferentes, mostrando que anteposto ao julgamento sobre a racionalidade do outro há um processo de dominação intercultural: “O processo de dominação (...) não se dá apenas pela força ou pelo peso das tecnologias criadas pelo mundo industrial, dá-se também (...) pela hegemonia do discurso ocidental, de raiz européia" (OLIVEIRA, 1998b, p. 175).

SOARES (1997), ao fazer revisão sobre os estudos sobre medicamento e sua relação com o meio social, coloca que o medicamento, ao se apresentar como ambivalente por ser ao mesmo tempo substância química, mercadoria de consumo e símbolo complexo, vai além do dualismo das conotações positivas e negativas. Nesse sentido, a autora sugere que as pesquisas sobre medicamentos partam da análise 
dessas ambivalências, nas contradições e conflitos resultantes das diferentes percepções e concepções individuais e coletivas sobre os medicamentos nos diferentes contextos envoltos por representações sobre doenças, saúde, tratamentos, corpo e relação entre profissionais de saúde e consumidores de medicamentos.

O consumo de medicamentos não se reduz à relação prescrição médica e sua aquisição e uso, envolve caminhos complexos, permeados por concepções e representações sobre o medicamento moldados pela diversidade de contextos socioculturais, fazendo parte de um diálogo educativo entre serviços de saúde e população. Pode-se referir a um consumo heterogêneo, a variações que respondem às imposições dos serviços de saúde. Portanto, compreender e interpretar o consumo de medicamentos a partir de seus consumidores colabora para refletir sobre os serviços de saúde e o modelo biomédico.

Olhar o medicamento como objeto interdisciplinar é posicioná-lo como construção histórico-social dinâmica, ganhando novas formas de uso ao serem os medicamentos ciclicamente aferidos pelas ciências e reavaliados individual e socialmente. Através dos medicamentos ocorrem explanações sobre os modos de cuidar das doenças, revelando conflitos de saber inter e intra usuários de medicamentos e profissionais de saúde, sugerindo modos de consumo.

Portanto, pesquisar consumidores de medicamentos está além da aplicação de questionários fechados que acompanham a lógica do modelo biomédico. Deve-se ser cauteloso para não substituir reflexão sobre o consumo de medicamentos por coerção padronizadora. Nesse sentido, as diferentes profissões associadas ao consumo nos serviços de saúde devem interagir de forma dialógica entre si e com a população. $O$ medicamento funciona como fio que une profissões e a comunidade.

Observo que a procura por racionalidade do modelo biomédico não se reduz ao espaço laboratorial, ela tenta percorrer desde as pesquisas na descoberta de um novo medicamento até o meio social, reafirmando sua trajetória que se vê meio a conflitos desencadeados por sensibilidades e subjetividades. Também na relação do consumidor de medicamentos com os prescritores, seja em hospitais ou em seu meio sociocultural, o medicamento carrega outros sentidos além de uma substância que se 
comunica somente com a doença, o consumidor se mostra como sujeito sensível. Quando se questiona as ações autoritárias da medicina ocidental ou oficial com o uso de medicamentos, estou também me referindo à preservação de práticas etnocêntricas, que se relacionam com a imposição do modelo biomédico e de seus medicamentos frente aos tratamentos populares e religiosos. Não é apenas um medicamento que adentra o corpo, é um modelo, perseguido e reavaliado desde a elaboração nos laboratórios farmacêuticos e que corresponde socialmente ao sistema capitalista.

O medicamento percorre vários percursos envolvendo desde as pessoas que circunvizinham o usuário até profissionais de saúde. Os efeitos farmacológicos dos medicamentos, ao se tornarem descritíveis, revelam a mercantilização da saúde, fazendo parte de uma comunicação entre profissional de saúde, indústria farmacêutica e população consumidora. O consumo de medicamentos, ao se localizar acima das questões financeiras dos consumidores, como objeto subjetivado, torna-se peça chave nas explorações capitalistas, sendo colaborado pelas incertezas dos efeitos farmacológicos. Assim, quando se prescreve ou vende um medicamento, as falas objetivadas e os efeitos matematizados são destacados, porém deixando uma espécie de janela para os efeitos imprevisíveis, resguardando as insatisfações. A própria vida com sua ambivalência, dinâmica e pluralidade se transforma em um negócio, que simula uma objetividade para o ganho e destaca a subjetividade e a perplexidade para as perdas, para a morte e o sofrimento. Nesse sentido, pode-se verificar o silêncio dos consumidores e dos profissionais de saúde frente ao medicamento, reafirmando sua ação como mágica, inquestionável. 


\section{METODOLOGIA}

Esta pesquisa visa à utilização da abordagem qualitativa e ao uso da etnografia como base metodológica para seu desenvolvimento. Para isso, a coleta de dados está diretamente relacionada à minha inserção no ambiente pesquisado, à observação participante, contribuindo para aprofundar o conhecimento sobre as atividades de campo realizadas na cidade de Ribeirão Preto, Estado de São Paulo. Como esta pesquisa procura estudar as concepções de moradores de bairros populares sobre medicamentos antidepressivos e ansiolíticos alopáticos, buscou-se encaminhar a coleta de dados através de entrevistas abertas e observação participante nos locais escolhidos para desenvolver a pesquisa.

A entrevista é um momento de encontro entre pesquisado e pesquisador que se estende para este como objeto de análise, formando uma memória no entrevistar, por isso é tão importante o próprio entrevistador ser o pesquisador e transcritor das entrevistas, retornando a seus detalhes, gestos, expressões, situações e locais em que foi realizada a entrevista. Desse modo, ROMANELLI (1998) diz que entrevistado e entrevistador são mediadores do desconhecido, de um encontro intersubjetivo que ambos contribuem para que os fatos aparentemente comuns, invisíveis, sejam problematizados, e por isso o "outro" deve parecer estranho ao pesquisador, aflorando os fatos investigados, acontecimentos esquecidos e naturalizados:

“Já quanto à entrevista, é necessário considerá-la como processo e não apenas como produto da pesquisa empírica, o que envolve duas dimensões. A primeira refere-se à sua realização, instância de fluxo e de troca de experiência entre pesquisador e nativo em uma relação face à face, em que a alteridade entre ambos é condição e pressuposto para que o processo de comunicação ocorra. A segunda dimensão da entrevista está relacionada a seus resultados, vale dizer, à construção de fatos etnográficos" (ROMANELLI, 1998, p.125, grifo do autor). 
A observação participante procura descrever um evento, um grupo de pessoas ou um indivíduo em determinado contexto, descrevendo uma problemática anteriormente definida (VÍCTORIA e col., 2000). Segundo estes autores, a observação participante deve analisar o ambiente (localização, espaço interno e externo, relação entre pessoas e o espaço, transformações ao longo do tempo), os comportamentos pessoais (posturas, normas, aparências), a linguagem utilizada (tom de voz, gestos), os relacionamentos interpessoais envolvendo também o próprio pesquisador, a seqüência com que ocorrem os eventos observados e os momentos das ocorrências. Diferente do que ocorre na pesquisa participante, o pesquisador na observação participante não tem o objetivo de transformar a realidade vivenciada.

A contribuição da etnografia é vista a partir do reconhecimento de que compreender e explicar a realidade dos informantes deve partir do contexto social em que atuam (VÍCTORIA e col., 2000), e procurei compreender, a partir do contexto, o bairro, o local de moradia, o ponto de vista, as concepções de consumidores de medicamentos psicoativos (ansiolíticos e antidepressivos alopáticos), atendidos em serviços públicos de saúde.

A pesquisa etnográfica remete à diversidade e complementaridade dos dados obtidos através de: registros escritos (agenda pessoal, diário de campo e fichário básico), observacionais e discursivos (VÍCTORIA e col., 2000). Desse modo, é necessário que se tenha um planejamento antes de começar a pesquisa, pois o pesquisar deve ser aceito pelos possíveis entrevistados ${ }^{6}$. A esta consideração, na pesquisa etnográfica, o pesquisador deve estabelecer relação de proximidade e confiança com os informantes, baseada em princípios éticos, tendo uma relação de alteridade, como FONSECA (2000) diz:

"Trata-se, portanto, de comunicação e é neste quadro que inscrevemos esta reflexão sobre a alteridade. É preciso que tomemos certa distância em relação a esse outro, para nos comunicarmos com ele. Sem reconhecer e admitir a diferença, não há diálogo. Ao mesmo tempo, deve-se evitar a projeção desse outro para fora de nossa esfera; se ficar muito distanciado, a comunicação

6 Respeitando os preceitos éticos, foi utilizado Termo de Consentimento Livre e Esclarecido aos entrevistados para permissão da pesquisa. 
torna-se impossível. A alteridade se constrói na tensão entre esses dois pólos - o muito próximo que se confunde consigo mesmo e o muito distante que se apresenta como uma espécie inteiramente nova, de uma cultura irredutível àquela do pesquisador". (FONSECA, 2000, p. 211).

Escolhi bairro de grupos populares e suas interfaces com outros bairros próximos da cidade de Ribeirão Preto-SP atendidos pela Estratégia Saúde da Família e pelo Núcleo de Saúde Mental (NSM) do Centro de Saúde Escola (CSE) da Faculdade de Medicina de Ribeirão Preto da Universidade de São Paulo (FMRP USP $)^{7}$, chamado também de CSE - Cuiabá, pertencente ao Distrito Oeste. Fiz uma pesquisa de campo onde participei do contexto local em que vivem os consumidores e as consumidoras de medicamentos ansiolíticos e antidepressivos.

Busquei aprofundar as seguintes questões: 1) acrescentar ao consumo de calmantes (ansiolíticos) alopáticos o consumo de antidepressivos, devido ao fato de a maioria das pessoas entrevistadas em pesquisa realizada anteriormente terem referido que consumiam os dois medicamentos; 2) utilizar entrevistas abertas pautadas na biografia do entrevistado, ao observar que o consumo de medicamentos ansiolíticos e antidepressivos está relacionado com a seqüência de acontecimentos em suas vidas e não com uma etapa determinada, levando-me a entrevistar homens e mulheres adultos, não só idosos como fiz no mestrado e, por isso; 3) utilizar a análise do curso de vida, pois compreendo que são os eventos que ocorrem durante o curso da vida juntamente com as concepções sobre saúde e doença que coordenam o uso dos medicamentos; 4) analisar outros contextos envolvendo diferentes especialidades médicas, pois observei que o consumo se inicia também fora da prescrição psiquiátrica; 5) realização do trabalho no campo, que também possibilitará verificar o impacto da Estratégia de Saúde da Família.

Almejei aprofundar a abordagem qualitativa ao projetar um trabalho com a contribuição da etnografia e com entrevistas abertas que valorizassem o curso de vida do entrevistado e sua relação com o consumo de medicamentos. Nesse sentido,

Destaco que a pesquisa que desenvolvi no mestrado foi realizada com mulheres idosas que freqüentavam o citado Núcleo de Saúde Mental da FMRP-USP, e as entrevistas foram realizadas no próprio NSM com mulheres atendidas pela psiquiatria (MENDONÇA, 2005). 
estabeleci que iria buscar antes a relevância dos depoimentos, dos relatos de história de vida, a partir de um contexto de trabalho e registro etnográfico realizado no campo de pesquisa, o que não determinaria necessariamente um número de entrevistas a serem realizadas. O contexto do campo possibilitaria inclusive o uso das entrevistas incidentais e as aproximações sucessivas buscando captar eventos, circunstâncias e diálogos. Assim, o número de entrevistados foi relativo ao local, à quantidade de pessoas que moram na área escolhida.

De acordo com GEERTZ (1989), o trabalho etnográfico é a busca de significados através de uma "descrição densa" que parte da idéia de que a "cultura" se erige através dos significados construídos pelo próprio ser humano. Por isso, procurei aprofundar significados com minha presença, indo a campo de pesquisa: indo além do nível de análise que proporciona a realização de entrevistas, interagindo com o desconhecido para uma melhor interpretação, interagindo minha vivência na cidade e no bairro onde morei com a vivência de um Outro sob a perspectiva do consumo de medicamentos antidepressivos e ansiolíticos.

Utilizei as entrevistas sob a perspectiva das histórias de vida (método biográfico), que foram gravadas e transcritas ${ }^{8}$. As entrevistas centraram na vida cotidiana do pesquisado e de eventos que ocorreram durante sua vida que estariam relacionados com o consumo de medicamentos psicoativos (antidepressivos e ansiolíticos). Nota-se na etnografia que sua produção está organizada por um saber, que se utiliza de uma série de técnicas dentro do campo de pesquisa, nem sempre isolada de outras técnicas de pesquisa (ATKINSON e HAMMERSLEY, 1994). Além disso, a pesquisa etnográfica deve possibilitar aberturas para ser revisitada e questionada, encontrando novas perspectivas, novos olhares permitindo novas abordagens (PEIRANO, 1995).

8 Será utilizado o termo de Consentimento Livre e Esclarecido de acordo com a resolução 196/96 para ter a permissão de serem entrevistadas, esclarecendo aos possíveis entrevistados as questões envolvidas na pesquisa e seus objetivos. $\mathrm{O}$ termo inclui as seguintes explicações do pesquisador ao entrevistado sobre a pesquisa: justificativa e os objetivos da pesquisa; procedimentos que serão utilizados e propósitos, incluindo a identificação dos procedimentos que são experimentais; desconfortos e riscos esperados; benefícios que poderão ser obtidos, e procedimentos alternativos que possam ser vantajosos para o indivíduo. 
Desse modo, me apoiei na biografia do entrevistado partindo do consumo de medicamentos psicoativos, contribuindo na ênfase da relação tempo/espaço, o percurso ou curso de suas vidas, os sentimentos dados aos acontecimentos e seus significados (BRIOSCHI e TRIGO, 1987). A partir dos acontecimentos e vivência dos entrevistados (e, por isso, a análise das entrevistas é diacrônica) procuro aprofundar as relações entre o uso de medicamentos, a condição de gênero e o envelhecimento, este como processo do curso da vida (DEBERT, 1994), contextualizados com os serviços de saúde e o local de moradia.

Pretendi assim observar o espaço dos informantes e suas relações de sociabilidades nesse espaço, os comportamentos, os gestos, a linguagem, sua trajetória através do tempo (mostrando o presente, passado e os desejos ao futuro), entre outros. Além disso, todas as questões foram apoiadas também por pesquisa de referencial bibliográfico na área de gênero, grupos populares, curso de vida, para possibilitar a análise teórica das observações, registros e entrevistas feitos em campo, pois o referencial bibliográfico, os informantes e o pesquisador estão em um constante diálogo dentro de uma pesquisa etnográfica.

A história de vida do entrevistado pode também ser compreendida como relatos de sua vida restrita ao sujeito, exigindo entrevistas detalhadas, percorrendo desde o nascimento do entrevistado até a atualidade, entretanto, ao aprofundar sobre o sujeito, o pesquisador pode desconhecer a estrutura social em que o entrevistado está envolvido. Nesse sentido, as entrevistas aqui procuraram descrever antes do curso ou trajetória de vida, os acontecimentos envolvendo o consumo de medicamentos psicoativos, seus consumidores e a estrutura social, o que leva a distanciar de um conceito de história de vida que se pauta somente na biografia, na história do sujeito, unicamente em sua história, no curso de suas vidas, no seu envelhecer (BOURDIEU, 1996), por isso a biografia é aqui temática e socializada.

Porém, utilizo o mesmo caminho utilizado nas entrevistas que buscam relatos de vida, que são também chamados de história de vida. Pois, segundo VÍCTORA e col. (2000), a história de vida, além de recuperar as experiências, acolhe mitos, tradições e crenças, sendo realizada ao longo de vários encontros e baseada na 
memória do informante, fazendo desenvolver interação entre o pesquisador e o informante, nutrindo relação de confiança e valorização da pesquisa. Desse modo, ao procurar analisar o consumo de medicamentos psicoativos através da trajetória de vida e sua relação com a estrutura social, pode-se apoiar na descrição de relato de vida realizada por BRIOSCHI e TRIGO (1987, p. 634): “Os relatos de vida têm sido uma fonte bastante rica para os estudos sobre trajetória de vida e mobilidade social, apreendendo as relações estabelecidas pelos indivíduos durante sua vida e indicando o sentido histórico e a dinâmica das relações sociais."

Complementando a observação participante e os relatos de vida acrescentei o uso da fotografia, unindo o texto à imagem. A união entre o olhar fotográfico com a etnografia contribuiu para que a fotografia não se tornasse somente recortes de imagens, mas sua contextualização com estrutura social e história de vida, relacionando tempo e espaço físico. Assim, fotografei os ambientes dos bairros que descrevem suas condições socioeconômicas, como vista panorâmica da pequena favela, conjunto de casas de forma que não as identificassem, praças públicas e feiras, fachadas de bares e armazéns, as fachadas dos prédios, salas ou ambientes de espera de pacientes para requererem os serviços de saúde (retirar medicamentos no CSE, sala de espera de atendimento nos Núcleos de Saúde da Família).

Inseri imagens que confrontam e se comunicam com a relatos de vida das pessoas entrevistadas, numa observação participante, mostrando a interação entre memória do passado, as tradições e as mudanças socioculturais em um processo em que o novo e o velho estão presentes, seja na pessoa, no indivíduo, nas moradias, no modo ou estilo de vida, na formação dos bairros das cidades, na arquitetura das casas e prédios públicos, nas mudanças ocorridas no corpo físico das pessoas e dos espaços. Procurei revelar diversidades de modos de vida, de olhares, da realidade, como nos diz ANDRADE (2002, p. 18): “as imagens 'dialogam' com a realidade e com a representação dessa realidade - as imagens também são observações estéticas e documentais da realidade".

A contextualização das imagens fotográficas não se resume a si própria, as imagens não param na fotografia, possui diversos olhares, seja de quem a tira seja de 
quem a olha. $\mathrm{O}$ encontro das cenas a serem possivelmente fotografadas não está ausente de conflitos e sensibilidades, muitas situações podem se recusar a serem fotografadas por sensibilizar o fotógrafo, evitando elevar o sofrimento do outro como espetáculo (SONTAG, 2003). A pesquisa etnográfica, ao ser vista como exercício envolvendo a interação entre sujeito e objeto, entre pesquisador e pesquisado, considerando suas singularidades, é também fruto de um processo temporal gerador de conflitos e questionamentos que leva as técnicas de pesquisa a interagir com realidades diferentes (ADORNO e CASTRO, 1994). Nesse sentido, a fotografia é um recurso a mais para contextualizar diferenças, experiências e contrastes de perspectivas revelados no campo, colaborando para revelar as diversas projeções sociais, do encontro entre tempos diferentes simbolicamente representados.

A fotografia é vista aqui como auxiliadora da observação participante, ordenando dados e fragmentos da realidade observada (ANDRADE, 2002), pois a descrição da realidade socioeconômica através do olhar do pesquisador possivelmente é melhor fundamentada com o apoio de imagens fotográficas dessa realidade, interagindo visão do observador e do observado. As fotografias fazem parte de um consentimento, levando a contextualizar imagens fotográficas com o modo de vida dos moradores dos bairros, sua realidade social, relacionando partes visíveis reveladas no corpo, na moradia, no bairro com partes invisíveis da história de vida das pessoas entrevistadas como sofrimento psíquico, as dificuldades relacionadas ao corpo e à estrutura social. Comunico imagens com escrita, verificando como os medicamentos ansiolíticos e antidepressivos estão intercalados na realidade social. No Termo de Consentimento Livre e Esclarecido consta o pedido para a realização de fotografia e acrescentei que antes de tirar qualquer fotografia referente ao ambiente doméstico dos entrevistados e a partes de seus corpos foi pedida permissão, sendo a decisão respeitada, evitando que o sofrimento sobreponha parâmetro ético e o seu mau uso fora dos objetivos da pesquisa (CAROSO, 2004), por isso procuro não identificar pessoas através das fotos.

Segundo BITTENCOURT (1998), as imagens fotográficas ampliam compreensões e clareza a respeito do campo pesquisado quando problematizadas 
com o texto, revelando, além dos fatos narrados, experiências humanas, as situações não verbais, expressões faciais, movimentos, lugares, memórias:

"Por meio de eventos imagéticos, os sujeitos do encontro etnográfico recriam uma realidade negociada cuja congruência é estabelecida por um laço significativo entre as experiências vividas e o universo da representação. Se o encontro etnográfico consiste em um relato de experiências vividas e compartilhadas, fotografias como meios e produtos dessa experiência fornecem pronunciamentos visuais dos atores sociais e do etnógrafo ao recriar um universo de sentido." (BITTENCOURT, 1998, p. 205).

As fotografias somam-se à observação participante, contribuindo para interpretar e compreender o universo pesquisado. Além disso, pode-se completar que as imagens fazem parte dos relatos de vida ou história de vida, como bem ilustra QUEIROZ (1983, p. 173):

"Não basta o pesquisador consignar os depoimentos obtidos; soltos nada significam. É preciso que anote cuidadosamente tudo quanto sabe a respeito do depoente, de sua vida, profissão, nível social, ambiente em que vive, para que a opinião dele se situe dentro de determinado contexto e queira dizer qualquer coisa. Também as condições em que se realizou a entrevista devem ser relatadas."

Foram escolhidos dois pontos iniciais para o encaminhamento da pesquisa, o percurso relacionado à aquisição de medicamentos nos serviços de saúde (dispensação de medicamentos em uma farmácia do serviço público de saúde para os bairros pesquisados) e a contextualização do consumo a partir das concepções dos usuários.

$\mathrm{Na}$ área do Distrito Oeste, haviam 4 núcleos de saúde da família, que iniciaram suas atividades a partir de 1999 no município de Ribeirão Preto, sendo direcionados a uma população estimada na época de 20.000 pessoas, e que eram ligados ao Centro de Saúde Escola Sumarezinho (CSE). Nesta área o desenvolvimento de pesquisas dentro dos Núcleos de Saúde da Família (NSFs) tornou-se referência, apresentando em 200358 projetos de pesquisa (CACCIABAVA, 2004).

De acordo com o relatório de atividades do Centro de Atenção Primária da Faculdade de Medicina de Ribeirão Preto da Universidade de São Paulo, de 2007 
(disponível em: <www.fmrp.usp.br/cap>), o CSE e os NSFs possibilitam o desenvolvimento de projetos de pesquisa, extensão e ensino na Universidade, participando principalmente as unidades de ensino e seus cursos do campus da Universidade de São Paulo em Ribeirão Preto: cursos de Fisioterapia, Fonoaudiologia, Informática Biomédica, Medicina, Nutrição,Terapia Ocupacional, Enfermagem, Odontologia, Farmácia, Psicologia, Educação. Relacionando-se a estes cursos, observa-se a inserção de pesquisa de iniciação científica e de pós-graduação (especialização, mestrado e doutorado). Segundo este relatório, pretende-se expandir os NSFs, cobrindo áreas antes não cobertas como os bairros Jardim Paiva, Portal do Alto e Eugênio Mendes Lopes. O serviço ambulatorial do Núcleo de Saúde Mental possibilita assistência a cerca de 140.000 pessoas, possuindo em 2007 cerca de 1.300 pacientes. Observaram-se os seguintes dados sobre as atividades desenvolvidas pelo CSE em uma área de cobertura com cerca de 150.000 pessoas: 108.009 (pronto atendimento em Clínica Médica de 74.801 mais 33.208 em Pediatria), atendimento básico de 26.548 pessoas, 738 procedimentos cirúrgicos. Além destes atendimentos, fez-se um total de 28.993 atendimentos especializados (ortopedia, cardiologia, saúde do trabalhador, dermatologia, psiquiatria, endocrinologia, etc). De acordo com os dados relativos às atividades assistenciais, em 2007 haviam 3.808 famílias cadastradas pelos núcleos de saúde da família.

Acrescento que o projeto de pesquisa foi aprovado por dois Comitês de Ética em Pesquisa (ver documentos em anexos), o primeiro pelo comitê do local em que seria desenvolvida a pesquisa (Comitê de Ética em Pesquisa do Centro de Saúde Escola da Faculdade de Medicina de Ribeirão Preto da Universidade de São Paulo) e pelo Comitê de Ética da Faculdade de Saúde Pública da Universidade de São Paulo.

Através da farmácia do Centro de Saúde Escola (farmácia pública) verificouse pelo sistema informatizado a existência de vinte e nove pessoas adultas que utilizaram os dois medicamentos (antidepressivos e ansiolíticos) entre junho de 2006 a junho de 2007 e que pertenciam à área de cobertura do Núcleo de Saúde da Família que foi investigada. Dessas pessoas, foram encontradas vinte e quatro pessoas adultas acima de 18 anos, não tendo sido encontradas as demais, sendo relatado por alguns 
moradores que já haviam mudado ou que haviam falecido. E alguns dos possíveis entrevistados não quiseram assinar o termo de consentimento, mas concederam a entrevista, sendo aqui incluídos apenas na observação participante, mesmo dizendo que poderiam relatar o que disseram. Um homem que estava na lista também disse que nunca havia tomado os medicamentos psicoativos. Enfim, foram incluídas quinze entrevistas realizadas nessa área.

As entrevistas realizadas na área das casas luxuosas também não foram inseridas, ficando restrita à observação participante. Em relação à área do conjunto habitacional (COHAB - Companhia Habitacional), foi incluída somente uma parte do bairro, a qual era vista pelos próprios moradores como uma das três subdivisões, que interligava com as outras áreas pesquisadas. $\mathrm{Na}$ parte da $\mathrm{COHAB}$, foram entrevistadas oito pessoas, sendo uma mulher não contida na listagem da farmácia, que era de doze pessoas. As pessoas não incluídas nas entrevistas foram quatro mulheres e um homem: duas mulheres que não foram encontradas em suas casas, uma não quis conceder a entrevista e outra mulher que havia concedido a entrevista por um buraco com um cano na parede (não assinando o termo de consentimento), e o homem não foi encontrado.

Então, são de 23 entrevistados (15 moradores da área de abrangência do núcleo de saúde da família e 8 moradores da área do bairro de casas COHAB) que construo os acontecimentos individuais e coletivos envolvidos com o consumo de medicamentos psicoativos, criando através da relação tempo e espaço a problemática de vidas relacionadas aos medicamentos. A análise das entrevistas se organiza como construção desta problemática, relatando acontecimentos que se interagem através da fala dos entrevistados, preservando a singularidade de cada um destes. Foram entrevistados cinco homens com idades entre 30 e 52 anos de idade. As mulheres variaram de 25 anos a 76 anos, sendo quatro com idade acima de 60 anos.

A análise de dados almeja a interpretação, a busca de sentidos, ir além das aparências, buscar as mensagens ou representações dos entrevistados, assim como a implementação de críticas, notar as contradições, as dinâmicas envolvidas nos processos históricos. Na pesquisa etnográfica, os dados não fazem parte apenas de 
um fragmento, de etapas da pesquisa, são constantemente construídos através de uma relação dialógica entre o observador (pesquisador) e o observado.

A partir de janeiro de 2007 até abril de 2008, convivi com a população local, conversando, freqüentando os lugares considerados públicos como os bares, lanchonetes, supermercados, mercearias, padarias, farmácias, serviços de saúde. A proximidade com a população faz com que as diferenças sejam dialogadas, o que leva a pesquisa a ser questionado. A pesquisa no posto de dispensação da CSE foi realizada mais intensamente durante os meses de maio a julho de 2007.

Foram colhidos dados do serviço público de assistência farmacêutica ${ }^{9}$ do Centro de Saúde Escola (CSE) da Faculdade de Medicina de Ribeirão Preto da Universidade de São Paulo (FMRP - USP) do Distrito Oeste, chamado de CSE Sumarezinho ou CSE - Cuiabá, de pacientes consumidores de medicamentos ansiolíticos e antidepressivos alopáticos. $\mathrm{Na}$ farmácia foram colhidas informações sobre os pacientes, descrevendo o serviço realizado (observação participante). No banco de dados de dispensação de medicamentos, separei os consumidores adultos de medicamentos ansiolíticos e antidepressivos alopáticos. Depois, anotei endereços e locais em que foram atendidos pelos serviços médicos públicos do CSE. Utilizei como material os computadores (dados eletrônicos) de dispensação de medicamentos psicoativos (ansiolíticos e antidepressivos), que tinham informações sobre os pacientes e informações prestadas pelos trabalhadores do serviço. Os pacientes foram selecionados a partir do local de moradia, pertencentes à área de um Núcleo de Saúde da Família. Além disso, foram selecionados os pacientes pertencentes a um bairro que fazia divisa com a área do Núcleo. Foram selecionados pacientes de uma parte desse bairro que ficava próxima a área de cobertura do Núcleo, promovendo um

9 A Resolução do Conselho Nacional de Saúde de número 338, de 06 de maio de 2004, define Assistência Farmacêutica: "Conjunto de ações voltadas à promoção, proteção e recuperação da saúde, tanto individual como coletiva, tendo o medicamento como insumo essencial e visando ao acesso e ao seu uso racional. Este conjunto envolve a pesquisa, o desenvolvimento e a produção de medicamentos e insumos, bem como a sua seleção, programação, aquisição, distribuição, dispensação, garantia da qualidade dos produtos e serviços, acompanhamento e avaliação de sua utilização, na perspectiva da obtenção de resultados concretos e da melhoria da qualidade de vida da população". 
enriquecimento da pesquisa à medida que promovia maior diversidade dos consumidores dos medicamentos.

Nos dados fornecidos pelo sistema informatizado da farmácia, pode-se contar com separação dos usuários por sexo, idade, endereço da residência. Foram separados os pacientes que consumiam os dois grupos de medicamentos. Com isso, foram escolhidos os bairros para a pesquisa. Além disso, tornou-se possível observar outro serviço de saúde, o Núcleo de Saúde da Família que atendia parte dos bairros da pesquisa.

A observação participante realizada na farmácia possibilitou a interação e a análise tanto de seu ambiente e funcionamento interno quanto externo, interagindo com os funcionários e os pacientes usuários do serviço. Foi anotado e descrito como a dispensação ocorria através da visão do lado interno para o externo da farmácia, relatando através de diário de campo os diálogos realizados com os funcionários da farmácia, também como os pacientes eram vistos e como o processo de entrega de medicamentos era realizado. Do lado externo para o lado interno da farmácia pode-se verificar como os pacientes suportavam o tempo de espera na fila e como foi realizada a dispensação dos medicamentos. Além disso, durante a análise do lado externo da farmácia, fiquei na fila de espera da dispensação dos medicamentos pelos funcionários da farmácia conversando com os usuários do serviço, anotando os comentários considerados pertinentes para o desenvolvimento da pesquisa. Foi também realizado um trabalho fotográfico do ambiente em que ocorria a dispensação de medicamentos. Assim, pode-se anotar tanto o ambiente estrutural da dispensação de medicamentos como a subjetividade envolvida.

Depois de colhidos os dados dos pacientes na farmácia, a fim de selecioná-los para serem entrevistados, visitei os bairros e os pacientes consumidores de medicamentos ansiolíticos e antidepressivos, pedindo autorização para realização da pesquisa. Além disso, observei o funcionamento dos serviços relacionados à Estratégia de Saúde da Família através de observação participante. Foram feitas visitas em quatro Núcleos de Saúde da Família ligados ao Centro de Saúde Escola Sumarezinho (CSE). No distrito, pela diversidade de moradores, dentre quatro 
núcleos, escolhi a área de um Núcleo de Saúde da Família. Assim, foram definidos os bairros e as pessoas que foram entrevistadas.

Assim, a partir dos dados fornecidos pela farmácia foi possível escolher a área de abrangência de um dos Núcleos de Saúde da Família (NSF). Desse modo, depois de escolhido o NSF, foi realizada a primeira inserção no campo de pesquisa no sentido de bairro, analisando como a população usuária via este NSF como prestador de serviço. Durante a estada no NSF foi possível verificar como o processo de medicalização se inseria nos bairros através dos medicamentos prescritos. Inicialmente, foi feita uma pequena excursão com os agentes comunitários de saúde, analisando quais os seus principais papéis nos bairros, assim como os inumeráveis alunos que passam semanalmente dos diversos cursos do Campus da Universidade de São Paulo de Ribeirão Preto, como os da medicina, fisioterapia, farmácia, odontologia, psicologia, entre outros. Em seguida, depois de analisadas as possíveis dificuldades da inserção nos bairros e nas residências dos usuários de serviços, as incursões nos bairros cobertos por esse NSF foram realizadas de forma individual pelo pesquisador. Os bairros abrangidos por este Núcleo de Saúde da Família envolviam uma diversidade de condições econômicas, indo desde o ambiente formado por favelas ao ambiente formado por casas luxuosas.

Colhi informações prestadas pelos trabalhadores da Estratégia de Saúde da Família dos bairros escolhidos: conversando com os agentes comunitários de saúde e outros profissionais dos Núcleos de Saúde da Família, convivendo com os moradores da área pesquisada. Neste contexto, colhi informações sobre a estrutura dos bairros, o ambiente das casas, os olhares, sendo de forma escrita e fotográfica. Os bairros eram formados por quatro ambientes característicos: favela, casas de antigos moradores, casas do conjunto habitacional (COHAB) e por casas novas e luxuosas. Estas diferenças das casas não se caracterizavam como linhas delineadoras de bairros.

Assim, passei a ir às casas das pessoas selecionadas para a realização das entrevistas, observando o ambiente em que estavam inseridas e como este estava relacionado ao uso de medicamentos antidepressivos e ansiolíticos. Entrevistei pacientes que residiam nos bairros inseridos na pesquisa e que haviam obtido, no 
posto de dispensação ou "farmácia" (como é chamado), medicamentos antidepressivos e ansiolíticos. Durante a inserção no campo nesses bairros, pode-se conhecer, através da observação participante, entrevistas e do uso de imagens fotográficas, o cotidiano de seus moradores, revelando diferenças e semelhanças, colaborando para problematizar o consumo de medicamentos psicoativos e sua relação com serviços de saúde, condições socioculturais, curso de vida, analisando os conflitos envolvidos neste consumo. Além disso, complementando uma análise mais local da cidade de Ribeirão Preto, fiz um percurso que também englobou a cidade como um todo em relação à dispensação de medicamentos pelas drogarias. 


\section{RESULTADOS E DISCUSSÃO}

\subsection{LOCAL DA PESQUISA: A CIDADE DE RIBEIRÃO PRETO}

A cidade de Ribeirão Preto-SP é perpassada pelo discurso desenvolvimentista, servindo como modelo almejado por uma ótica voltada ao sentido de progresso econômico, que nem sempre está acompanhado de qualidade de vida e benefício social.

Assim, esta cidade foi fundada por uma perspectiva que relaciona religião e local de morada de uma população. Nesse sentido, o surgimento da cidade começa com demarcação de terras doadas para a construção da capela de São Sebastião, o santo dos fazendeiros, em 1856, marcando a religião e agropecuária como central em seu desenvolvimento. Contudo, segundo SILVA (2006), a cidade de Ribeirão Preto só ganhou um impulso do crescimento urbano a partir do final do século XIX.

Pode-se notar através das fotografias seguintes a convivência entre passado religioso (atrás da imagem do São Sebastião) e o presente urbano (na frente da imagem do santo), com a verticalização da cidade e o comércio intenso. 

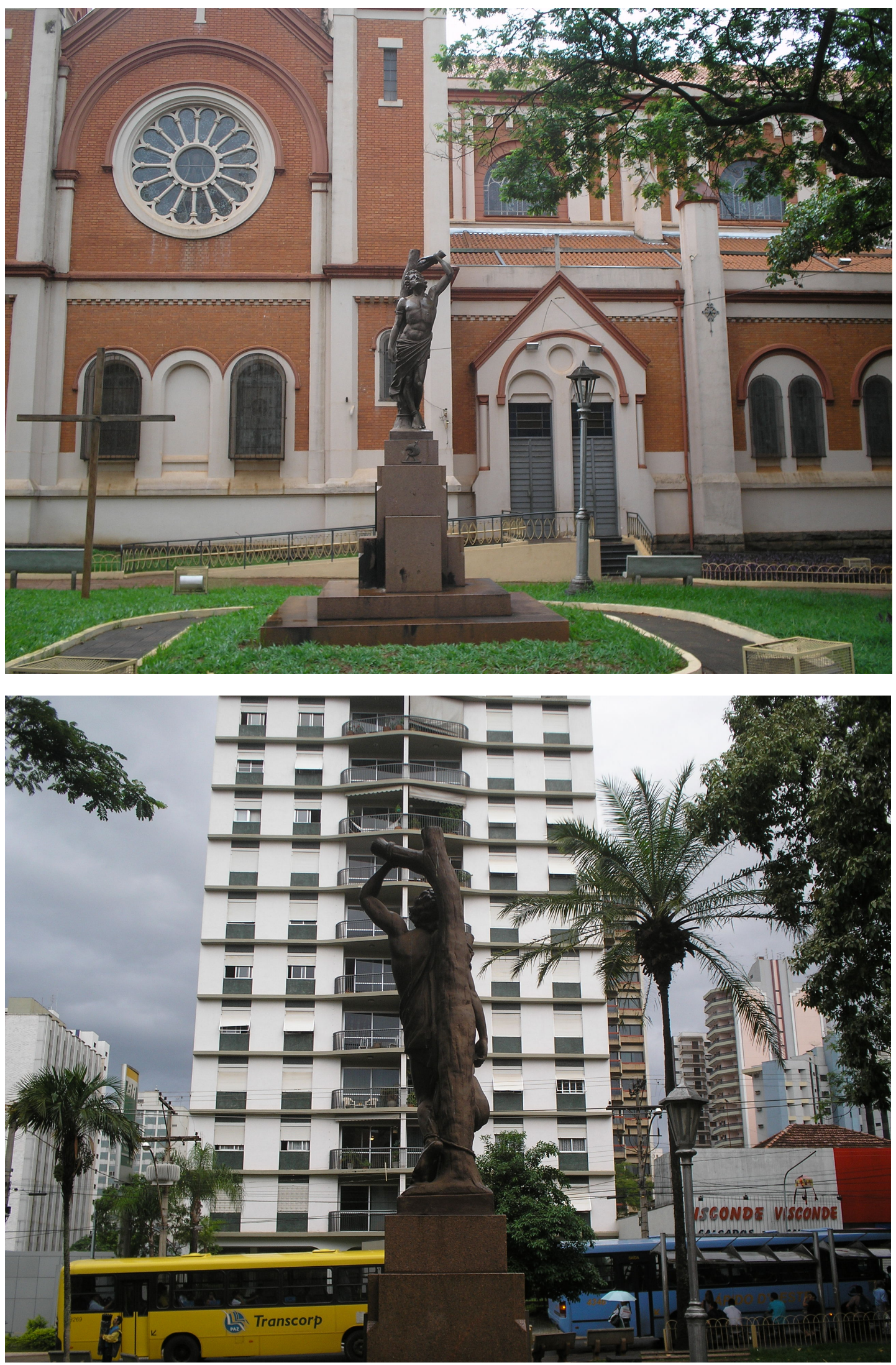
A cidade de Ribeirão Preto é contextualizada primeiramente pela produção de café e em seguida pela produção de cana-de-açúcar. Com a produção de café pode-se verificar a origem do campus da Universidade de São Paulo, onde está localizado o chamado Museu do Café (fotos seguintes).
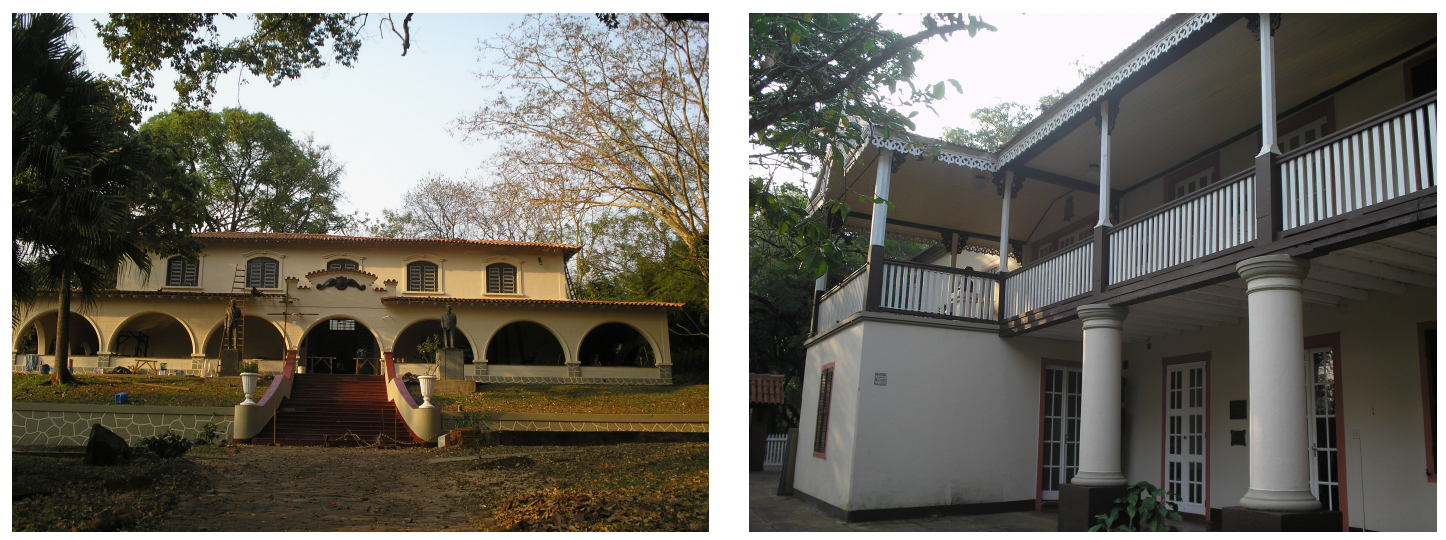

De acordo com SILVA (2006), o desenvolvimento urbano da cidade de Ribeirão Preto pode ser definido por quatro fases: 1) produção de café que propiciou as primeiras obras e a categorização da vila em cidade, propiciando um processo de migração, principalmente de europeus italianos, juntando aos nativos, negros libertos e trabalhadores vindos de Minas Gerais, reforçados pelos transportes da ferrovia que chegava à Ribeirão Preto pela Companhia Ferroviária Mojiana, unindo o porto de Santos a Ribeirão Preto (de acordo com MIZUTANI (2002), no ano 1904 78\% da população era formada por estrangeiros e a produção de café estava centrada nas mãos de poucos fazendeiros). Portanto, a produção de café está na origem da cidade, assim como as obras voltadas para organização sanitária da cidade, como a construção de hospitais, controle de epidemias, construção de cemitérios para "leprosos", etc; 2) a segunda fase, definida a partir da Primeira Guerra Mundial, é marcada pelo desenvolvimento de bairros operários, marcando um processo de distinções e construção de prédios comerciais; 3) a terceira fase foi marcada pelo asfaltamento da rodovia Anhangüera em 1948, ligando Ribeirão Preto a Campinas, e pelo surgimento de indústrias de base tecnológica e pela fundação em 1951 do 
campus da Universidade de São Paulo (USP), favorecendo o aumento de mão-deobra especializada e de alto custo; 4) a formação de um parque agroindustrial em decorrência do plantio de cana-de-açúcar a partir da década de 1980, com aumento do trabalho sazonal, facilitou a formação de favelas, ao mesmo tempo em que ocorria a verticalização da cidade e construção de shopping em busca de mercado consumidor, criando uma nova arquitetura para o consumo de mercadorias.

Pode-se dizer que existe na cidade um processo de luta para melhores condições de trabalho que está relacionado ao percurso histórico-social da cidade de Ribeirão Preto. Se a imigração européia propiciou a concorrência com os antigos moradores (como os nativos e mineiros), ela persiste como forma de distinção na formação dos bairros, não se distanciando das teorias raciais que valorizavam os brancos europeus como referência aos outros grupos sociais. Assim, ser considerado “de fora", de outro lugar possui uma representação com conotações preconceituosas, que pregava a perfeição humana quanto mais próxima estivesse do branco europeu. Além disso, as novas facetas do desenvolvimento técnico-científico do século XX contribuíram, através das teorias eugênicas em conjunto com medidas sanitárias, para a segregação social, o surgimento de diferentes grupos sociais ou famílias que contextualizaram uma suposta homogeneidade dos moradores de uma cidade ou bairros, levando à segregação e ao afastamento de pessoas que não condiziam com o modelo eugênico para a periferia da cidade (DIWAN, 2007).

De acordo com PIRES (2004), descrevendo dados do IBGE (Instituto Brasileiro de Geografia e Estatística) do censo de 2000, Ribeirão Preto continha uma população de 504.923 (o censo de 2007 a população foi de 547.417) e com predominância urbana (mais de 99,5\%), e o município de Ribeirão Preto estava entre os $0,4 \%$ dos mais ricos do Brasil e com Índice de Desenvolvimento Humano Municipal (IDH-M, medida que relaciona renda, esperança de vida ao nascer e alfabetização), em vigésimo - primeiro no país.

A cidade de ribeirão Preto possui uma grande oferta de bens e serviços no setor terciário. PIRES (2004) destaca que o maior desenvolvimento econômico em Ribeirão Preto foi concentrado a partir da década de 1950. O clima, a qualidade do 
solo e capacidade para a utilização de técnicas sofisticadas utilizadas na agricultura contribuiu para que a cidade se tornasse o que chamavam de "Califórnia Brasileira".

A partir de 1970, a Região Administrativa de Ribeirão se destacava como uma das regiões com maior desenvolvimento agroindustrial com destaque para os produtos oriundos da cana-de-açúcar, laranja, soja. PIRES (2004) observou que a concentração de renda em Ribeirão Preto ser maior do que as cidades que circunvizinham contribuiu para o desenvolvimento do setor terciário da cidade, principalmente os relativos ao comércio atacadista, à educação, e à saúde. Em relação à saúde e à educação, o autor observou que a existência da Faculdade de Medicina da Universidade de São Paulo encadeou uma rede de comércio e serviços de apoio, como laboratórios, clínicas, venda de equipamentos, indústrias especializadas, servindo para propiciar o desenvolvimento econômico e para atrair pessoas de todo o país, estimulando o comércio e os serviços locais, evidenciando o consumo e a produção de produtos médico-odontológicos e farmacêuticos, sendo facilitados pelo desenvolvimento de pesquisas e serviços em decorrência da existência de mão-de-obra especializada.

Os incentivos ao setor terciário e sua relação com a educação e a saúde são demonstrados desde a fundação da primeira Faculdade de Farmácia e Odontologia do Estado na década de 1930, atraindo público consumidor, assim como a fundação da Faculdade de Medicina de Ribeirão Preto da Universidade de São Paulo, em 1952, a primeira do interior paulista, levando a cidade a tornar-se um centro de referência na área médica, em pesquisa, atendimento médico e educação (PIRES, 2004).

Acrescento que a mercantilização do ensino através do aumento do número de faculdades privadas possibilitou a Ribeirão Preto se tornar um pólo educacional para estudantes de várias partes do país, com destaque para a área de saúde como os três cursos de Medicina existentes na cidade, ministrados pela UNAERP (Universidade de Ribeirão Preto), pela Faculdade Barão de Mauá e pela Universidade de São Paulo.

Como aponta PIRES (2004), a cidade de Ribeirão Preto possuía no ano 2000 a maior densidade médico/habitante no Estado e a quarta posição em todo o país, 
tratando de uma rede com 1.929 leitos distribuídos em 23 centros de saúde e 63 unidades ambulatoriais e 9 hospitais, atendendo região e todo o país.

PIRES (2004) diz que, apesar de em 2000 a renda per capita média da cidade estar acima em $22 \%$ da média do Estado, ainda prevalecem situações de pobreza e desigualdades socioeconômicas, com o aumento do número de favelas e de pessoas em situações de pobreza, possuindo uma das regiões com maiores concentrações de renda.

As favelas, com grande concentração de migrantes em busca de trabalho, aumentaram na década de 1990. De acordo com PIRES (2004), no ano de 2001, Ribeirão Preto possuía 32 favelas cadastradas, com 4.600 domicílios.

Assim, a cidade de Ribeirão Preto é marcada por um sentido de progresso, aliando ciência e desenvolvimento econômico, enfatizando um contraste entre busca de mercado consumidor e desigualdade no acesso aos bens de consumo, como se pode observar através das fotos seguintes. 


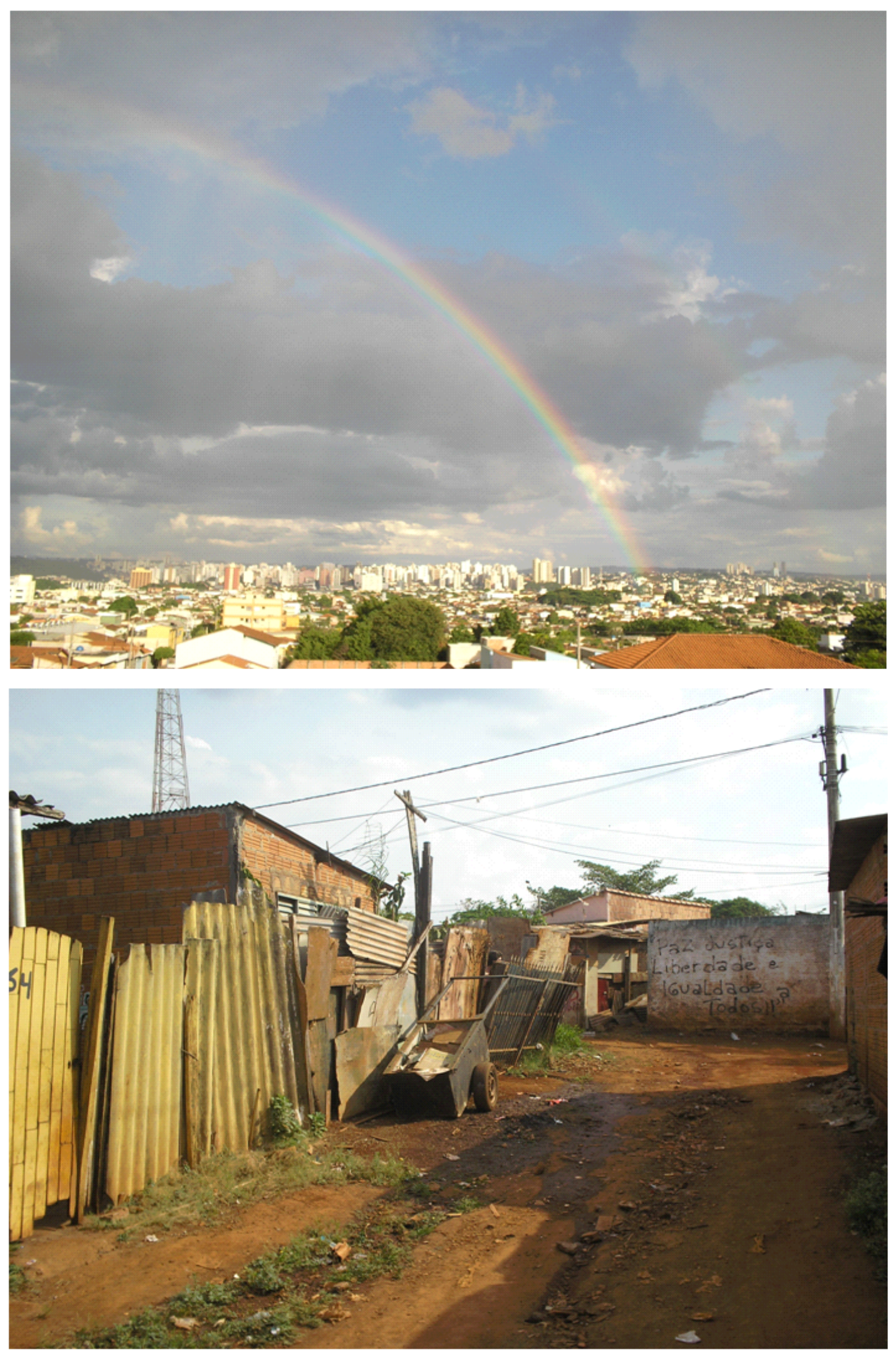


4.1.1 A cidade medicalizada: serviços de saúde e consumo de medicamentos como ordenadores de espaços

Observei que os serviços de saúde e o consumo de medicamentos colaboram na constituição da organização espacial de cidades. A cidade de Ribeirão Preto mostrou-se dividida espacialmente em relação aos serviços aqui analisados, relacionados aos comércios de medicamentos. Através dos significados dados aos medicamentos, pude concluir que os serviços de saúde, como Centro de Saúde, hospital, farmácia e drogarias contribuem para remodelar e estruturar bairros, sendo uma das justificativas de alguns moradores de morarem em bairros vizinhos a estes serviços. Estes serviços são contextualizados como modelo de progresso ditado pela união entre ciência e ganhos financeiros, levando a migração para esta cidade tanto de outras cidades do próprio Estado de São Paulo como de outros Estados.

Portanto, analisar o espaço geográfico através da medicalização da sociedade, da inserção de serviços de saúde, contribui para orientar políticas públicas e divisões de áreas voltadas para a melhoria de qualidade de vida da população, prevenindo o consumo desordenado de produtos farmacêuticos e serviços médico-hospitalares, contribuindo para pensar novas divisões administrativas relativas ao campo da saúde como a Estratégia de Saúde da Família. ADORNO (1999) mostra como a partir do século XIX a cidade produziu parâmetros contraditórios, por um lado construiu-se um novo estilo de vida, pelas facilidades do consumo, e por outro lado, intensificaram-se as diferenças e desigualdades ao revelar as condições precárias de vida impostas à população pobre. O urbano, segundo ADORNO (1999, p. 18), é lugar de negociação e conflito, "é um território de hierarquias, diferenças e desigualdades" produtor de dinâmicas, de transformações. A cidade se constrói como espaço de polarização, onde a "compra" por qualidade de vida está associada à 
aquisição e freqüência aos lugares considerados protegidos, indo desde lugares de lazer, comerciais (lojas, clínicas, hipermercados, aeroportos) até o tipo de casa habitada (exemplo, cercada com cerca elétrica), lugares interligados por circuitos particularizados (ADORNO, 1999), lugares que reservam medidas de segurança privada e que promovem a definição de qualidade de vida como objeto de consumo a ser comprado.

As comparações entre as cidades são comuns, geralmente é enfatizada a cidade como uma estrutura de aparência, onde poucos têm acesso aos espaços internos dessa aparência, seja devido ao capital simbólico (BOURDIEU, 2007), seja pelo processo de afastamento de moradores desses lugares. Enfim, é uma aparência pautada em um sentido de progresso, os edifícios, hospitais, casas luxuosas, shoppings, hipermercados. Uma aparência que contextualiza frases como "moro aqui porque aqui tem tudo", apesar das dificuldades de acesso a esse "tudo", que está relacionado aos bens de consumo.

De acordo com CONRAD (2007), medicalização consiste em definir um problema baseado em conhecimentos médicos-científicos, usando linguagem própria para descrevê-lo, usando parâmetros médicos para tratar os problemas identificados. De acordo com este autor, medicalização ocorre como parte da interação médicopaciente, tratando desde o indivíduo até um grupo social. A medicalização envolve a relação ciência-sociedade, relacionando com questões como gênero, velhice, sexualidade, normatização. A ciência nem sempre passa pelos serviços de saúde para chegar à sociedade, a mídia é uma grande colaboradora nesse processo. Assim, a medicalização é uma forma de difusão dos conhecimentos considerados científicos, sendo colaborada pelos serviços de saúde. Os medicamentos são parte do processo de medicalização e, ao serem consideradas tecnologias produzidas ou reelaboradas, para questionar o seu papel no processo de medicalização, deve-se perguntar: "quem os produz?".

Nesse sentido, pode-se encontrar a indústria farmacêutica como grande difusora da medicalização. Compreendo aqui por medicalização como um processo cíclico, envolvendo produção de medicamento e sociedade, sendo entremeado pelos 
serviços de saúde. A medicalização é assim um processo de difusão de conhecimentos médico-científicos.

Assim, a educação dos usuários sobre os riscos à saúde que os medicamentos podem provocar é primordial. Aqui, pode-se remeter a BOLTANSKI (1984), ao dizer que as diferenças sociais e de conhecimentos não permitem que a comunicação entre serviços de saúde e população seja efetiva, sendo que um não compreende o outro. Nesse sentido, compreender o consumo de medicamentos através da ótica de seus consumidores significa aproximar de conhecimentos alheios à ciência, é produzir autonomia e consciência sobre o consumo de medicamentos. A difusão dos conhecimentos está assim relacionada à estrutura social, sendo que as diferenças socioculturais levam a diferentes modos de consumo de medicamentos, que se distanciam do modelo imposto pela ciência relativa ao modo de ser consumido. Nesse sentido, analisar a cidade a partir dos locais de dispensação de medicamentos possibilita questionar desigualdades relativas ao consumo de medicamentos e sua associação com diferenças sociais. $\mathrm{O}$ acesso aos medicamentos com qualidade é uma questão debatida na Política Nacional de Medicamentos (BRASIL, 2001), porém não se debate a associação entre distribuição espacial e o número de serviços de dispensação de medicamentos, sejam eles públicos ou privados.

Remontando a um breve percurso da associação entre desenvolvimento das cidades e serviços de saúde, observei que a disposição dos serviços de saúde nas cidades foi uma questão continuamente debatida em conjunto com a preocupação de acesso pela população, principalmente em relação aos grupos populares. Estes, sendo acusadas dos considerados males existentes nas cidades (doenças, criminalidade e atraso econômico), foram chamadas no fim do século XIX e início do XX, de acordo com CHALHOUB (1996), de classes perigosas, o que justificou a fabricação de ordens que as disciplinassem e afastassem para as periferias das cidades. As partes centrais da cidade não são mais um lugar fixo para estes moradores constituírem suas casas, passando a ser lugares de passagem, em que o trânsito de pessoas e de carros são permissíveis em função de uma lógica para o consumo. 
Os conflitos são marcados por relações de poder em que o corpo se inclui, ora criando um habitus, como BOURDIEU (1999, 2007) nos coloca, algo que nos identifica, caracteriza no modo de vestir, falar, sentar, comer, inseridos em nosso corpo, um habitus de classe, visível pelo capital cultural, econômico e social, orientando lugares que freqüentamos, nossos interesses, nossa compreensão, levando a identificações, categorizações sobre o outro. Habitus se transforma como um marcador que vai além das condições econômicas, pois leva a identificação da origem sociocultural de pessoas. Habitus são vistos e criados pelas divisões que estão marcadas pelo fim do asfalto entre bairros e pelos modos de vida. É nesse mundo marcado pela diferença que as relações de poder se organizam, que uns se posicionam e se impõem sobre os outros, de um sexo e grupo social sobre outro. Como CERTEAU (2005) alerta, as seduções provocadas pelas estruturas de poder levam a ver a cidade como uma fachada encantadora e idealizada, esquecendo do mundo cotidiano dos afastados das vantagens que as relações de poder proporcionam, provocando enganos e esquecimentos. Assim, procurei adentrar espaços esquecidos como lugar de autonomia social e lembrados por imposições de uma ordem que favorece ora a determinado grupo social, ora a determinado sexo, analisando as relações com o consumo dos medicamentos antidepressivos e ansiolíticos.

Nesse sentido, o medicamento interage com um corpo que perpassa por diferentes conotações e possibilidades de investigações, como PORTER (1992) enumera: 1) O corpo como condição humana, o nascimento, reprodução e morte e sua aquisição de significados biológicos e transcendental, ganhando sentido de duração em anos ou fazendo parte da eternidade. O corpo é ora representado como processo, ora como transgressão. Um corpo morto pode ser representado desde um percurso contado em dias até uma simbologia preservada na memória. Como exemplo, o corpo de Cristo pregado na cruz promove inúmeras representações passadas à sociedade, como a associação entre sofrimento e recompensa, entre vítima e acusação, como servidão monoteísta e não resistências às explorações de outrem, como exposição de sofrimentos como justificativa do direito de terem prazeres, etc; 
2) O corpo possui uma forma valorizada, questionada, sugerida, condenada. O tipo de um corpo possui sentido histórico construído, pode-se verificar através de pinturas e descrições literárias que o corpo possui variações ideais representadas por uma época; 3) $\mathrm{O}$ corpo possui uma anatomia representada pela interconexão entre o mundo exterior e interior, um corpo para o outro e um corpo para si. O corpo se divide para revelar gracejos específicos, são os significados dados aos seios, aos braços, ao colo, à pele, ao coração, à cabeça, à barriga, ao pênis, à vulva, ao sangue, às secreções e excreções, às mudanças ocorridas pela doença ou pela idade, etc; 4) $\mathrm{O}$ corpo é parte comunicante com a mente e a alma, fazendo parte de sistemas de valores e julgamentos, orientadas por divisões que explanam sobre os sentidos históricos dados aos tratamentos e às doenças; 5) História do sexo, do gênero, do feminino, do masculino; 6) O corpo possui uma dimensão política, um corpo político que impõe comportamentos e modelos de corpos; 7) Corpo que se organiza através de gostos, de vestuários, tabus, desejos, posturas, moralidades, cosméticos.

As análises históricas encontram o processo saúde/doença através de diferentes caminhos, como o percorrido por historiadores da medicina, da farmácia, da doença, etc. São percursos que deságuam no corpo, fazendo deste plural. Assim, quando descrevo um sentido histórico dos medicamentos, estou comunicando com o corpo, que apresenta características integradas ao social, ao cultural, ao habitus, ao sexo, ao gênero, à velhice, à doença e à saúde. Cada pessoa que entrevistei tem uma voz que o representa, que se coaduna com seus sintomas, com o "nervoso", com suas tristezas, decepções, carências, insatisfações, etc, representadas no corpo. O corpo visto através de sua interação com medicamentos, corpo medicado, não é olhado pela separação entre mente e corpo ou natureza e cultural. O corpo é colocado além de um processo saúde/doença e se arraiga às imposições sociais, adquirindo aparências construídas na interação biológico-social-cultural, corpo disciplinado, controlado, obediente, que se veste, que possui posturas aceitáveis socialmente, corpo que também resiste, questiona, que discrimina e é discriminado. Procuro destacar os diversos aspectos socioculturais e biológicos relacionados ao corpo medicado, 
distanciando do reducionismo entre efeitos farmacológicos dos medicamentos e corpo biológico.

Assim, existe um deslocamento simbólico que contribui para a identificação da pessoa com o lugar em que mora, aparecendo por um habitus, a apresentação dos modos de vestir, falar, olhar, sentar, comer, ver, etc, inseridos no corpo através dos diferentes grupos sociais em que somos produtores de e produzidos por representações identificadoras (BOURDIEU, 2007). Freqüentar lugares em que as mesmas pessoas passaram por situações semelhantes durante seu percurso de vida é promover identificações, e perambular por lugares alheios a estes percursos é ser notado como um outro não incluído, freqüentemente banhado em olhares que discriminam, segregam. Ao tratar de espaços, analisamos trajetórias socioculturais que incluem um habitus formado pela classe social, pelo capital cultural e econômico das pessoas, levando a sermos identificados não somente como consumidores, mas a partir do que consumimos e de como fazemos uso, construindo espaços de distinções.

As preocupações sobre saúde pública estiveram sempre presentes na elaboração dos planos administrativos das cidades, contudo foram integradas somente a um sentido benéfico, faltando crítica sobre as ações relacionadas à saúde. Os serviços de saúde, além de produzirem melhorias na saúde da população, podem criar uma situação oposta, iatrogênica, os malefícios que os serviços de saúde podem causar (ILLICH, 1975). Os serviços de saúde podem contribuir no condicionamento de comportamentos facilitadores de explorações, impondo desejos de determinados grupos sociais sobre outros, como inserção de uma disciplina sobre o corpo, mantendo-o saudável e produtivo, e colaborando na formulação de manuais de boas normas geralmente dualistas, impondo uma suposta verdade considerada científica. Desse modo, a cidade funciona como estratégia de poder, fazendo dos ares fétidos produzidos pelos esgotos a céu aberto serem mais questionados do que a poluição atmosférica causada pelo gás carbônico e pela poluição sonora.

De acordo com PECHMAN (1991), cidade se diferencia de urbano ao se revelar por sua materialidade, enquanto o urbano significa um sistema abstrato de 
representação, sistema de idéias e ruptura ao mundo medieval místico, sagrado. O urbano a partir do século XVIII se destaca como um novo campo de poder e de dominação, oferecendo sentido ao espaço através das relações socioculturais, fundadas na oposição entre campo e cidade, pobre e rico, racional e irracional, atraso e progresso, tradicional e moderno. É através do urbano que surgiram diferentes disciplinas (como exemplo, a estatística e medicina social), para a manutenção do poder e do controle, impondo normas e ordens baseadas em um suposto saber científico (PECHMAN, 1991).

A cidade se constitui através de uma ordem racional, hierárquica, em que estão presentes conflitos entre poder e resistência, transparecendo imagens de confrontos entre bairros populares e condomínios luxuosos, entre mansões e favelas, entre shopping-center e mercado informal, etc. É através da cidade contemporânea que se pode visualizar o espetáculo do poder, as fachadas impregnadas de suntuosidade reveladas na verticalização das moradias e prédios comerciais, dos movimentos de carros, de transeuntes preocupados com seus empregos, fazendo-nos esquecer, como CERTEAU (2005) diz, da vida cotidiana, das respostas à imposição das estratégias de poder, de normas a serem seguidas, resistências, das artimanhas e adaptações inusitadas utilizadas pelos grupos populares para sobreviverem. E a partir de FOUCAULT (1984) notei como os serviços de saúde se relacionam com as estratégias de poder que regem a cidade, definindo espaços, comportamentos, modos de vida, aparência e performances do corpo.

As estratégias de poder estão relacionadas com o conceito de grupos populares, o que supõe fixar essas estratégias em determinado período histórico, não devendo descartar o processo dinâmico em que está envolvido. Nesse sentido, faz-se necessário responder como este conceito de Poder é formado e o que permite sua transformação ou permanência, apesar da existência de conflitos em sua elaboração. O conceito de Poder (FOUCAULT, 1988) comunica com o conceito de habitus (BOURDIEU, 2007), ambos impondo normas através de um universo relacional envolvendo conflitos e divergências, impondo comportamentos ditos normais e aceitados socialmente. O Poder está diretamente relacionado à Resistência, gerando 
assim conflitos, revelando desde a violência à coerção social. Assim, quando refiro a grupos populares estou me referindo às relações de poder e resistência.

Desse modo, se um conceito social muda é porque as relações de poder (ou o Poder em sentido totalizador) envolvendo esse conceito também mudaram, podendo estas relações serem imperceptíveis, ou somente destacadas suas formas terminais, como a dominação e efeitos de um grupo social sobre o outro (FOUCAULT, 1988). O Poder é a "multiplicidade de correlações de força imanentes ao domínio" marcadas por contradições abarcando desde questões socioeconômicas aos conflitos reveladores de hegemonias, sendo afirmado e transformado em cadeias interligadas na sociedade (FOUCAULT, 1988, p. 88-89). O Poder não ignora conflitos e resistências, se reproduz através dele em sua ação reprodutora de dominações para o controle. Portanto, o consumo de medicamentos está ligado às relações de poder, contribuindo para localizar pontos onde essas relações ocorrem, onde o Poder se apresenta com mais consistência e susceptibilidade.

A medicalização de conflitos é condizente com o tratamento de insatisfações, provocando exigências que vão além dos limites do corpo. De acordo com DUARTE (1986), as insatisfações sociais dos grupos populares (chamada pelo autor de classes trabalhadoras) são reveladas aos médicos através dos diversos significados dados ao "nervoso", perturbações culturalmente determinadas a partir de alterações baseadas em um estado normal, e são diagnosticadas como doenças, entre elas as mentais, podendo levar a prescrições de medicamentos. Os limites do corpo são subjetivados nos significados dados ao "nervoso".

As dificuldades financeiras levam a cimentar diversos contextos moldadores de conflito em que os medicamentos assumem o papel de silenciador, pois nem sempre a união entre homem e mulher se detém à ajuda mútua. Tomar o medicamento, além de deixar o corpo disciplinado, faz dormir e acordar na hora certa e com tranqüilidade, controlado, pronto para suportar e evitar desavenças. O controle do corpo, envolvido por imposições sociais, leva ao orgulho de suportar todas as normas sociais determinadas, mesmo sendo parte de contextos envolvendo agressões e violências, levando a se considerar normal e parte da coletividade. 
De acordo com FOUCAULT (1988), a resistência se revela como adversário em vários pontos, apresentando-se nas relações de poder, sendo também pontos móveis e transitórios, promovendo rompimentos e remodelamentos que vão desde o institucional, o social, até o individual. Assim, são resistências, no plural, que estão correlacionadas no poder, presas ao seu campo estratégico, mas que "são casos únicos: possíveis, necessários, improváveis, espontâneos, selvagens, solitários, planejadas, arrastadas, violentas, irreconciliáveis, prontas ao compromisso, interessadas ou fadadas ao sacrifício" (FOUCAULT, 1988, p. 91). Retirar qualquer agressividade ou insatisfações através do consumo de medicamentos seria produzir o oposto de resistência, o oposto de revolta, o presente de dependência química e ausência de autonomia.

Não se pode esquecer que o conceito de Poder também é diverso nas diferentes culturas. CLASTRES (2003), estudando os índios na América do Sul na década de 60, mostra que o Poder pode se desvincular da dominação à medida que a sociedade se organiza para desmembrar o sistema comando-obediência do Estado. Assim, a sociedade indígena é vista como sem Estado, o chefe indígena representa a coletividade, mas não lhe está vinculada uma obediência inquestionável, o chefe pode ser abandonado caso não detenha o domínio da palavra, o oposto de violência, e dê segurança ao grupo. Entretanto, para CLASTRES (2003), a população indígena é representada para o mundo ocidental como pertencente a uma etapa anterior de seu desenvolvimento, ignorando seus modos de vida, isto é, mostrando-se evolucionista e etnocêntrica. Não se pode negar que a busca de uma ocidentalização da sociedade brasileira é revelada nas relações diretas com o mundo europeu. Não é difícil verificar que a medicina oficial e o Estado procuraram no decorrer da história brasileira anular outras formas de tratamento de doenças.

A estrutura objetiva e o pensamento seguem uma mesma ação, mas destaco viés no habitus, nos limites do que é incorporado e aceito: os momentos das revoltas, das insatisfações. O que é, em partes, acolhido por BOURDIEU (1999, p.22), ao dizer que a "luta cognitiva" sempre tem seu lugar, a se rebelar contra a realidade imposta, seja através da existência de "interpretações antagônicas, oferecendo aos 
dominados uma possibilidade de resistência contra o efeito de imposição simbólica" ao impor-lhes a exigência de seu papel de dominador, cumpridor com suas obrigações, que é apoiado por homens, mulheres e instituições como família, igreja, Estado, Escola. Por isso, qualquer mudança deve prever a compreensão do universo relacional entre classes sociais, entre homens e mulheres, a minar as condições que tornam possíveis a incorporação das estruturas do poder institucional, social e individual, e objetiva e subjetivamente, revelando os limites biológicos, culturais e sociais. Portanto, a sociedade considera determinados grupos sociais como perigosos, que se desviou das normas impostas ao fazer "leituras" divergentes de quem detém o poder na sociedade (VELHO, 1974): o desviante passa a ser o problema, e não o que ele questiona.

Ampliando o uso da palavra qüiproquó utilizada por CERTEAU (2005) para caracterizar as enganações produzidas por um poder sobre a vida popular, produzindo controle e disciplina, relaciono a um sentido direto com o consumo de medicamentos. De acordo com o Dicionário Houaiss, qüiproquó era um livro contido nas farmácias com a função de substituir e indicar as substâncias prescritas pelos médicos quando não se encontravam na farmácia, sendo freqüente o equívoco e a produção do oposto desejado: o envenenamento. Analisei se o consumo de medicamentos antidepressivos e ansiolíticos pertence a estes equívocos, perguntando se a medicalização de conflitos sociais não estaria administrando venenos com aparência de medicamentos, fazendo remeter a uma seqüência histórica de medicalização de grupos sociais afastados da estrutura de poder, como atitudes que ao basearem em modelos conotados como perfeitos, produzem discriminações e preconceitos, como ações baseadas na eugenia.

Incluir os serviços de saúde como moldadores dos espaços, das divisões contidas na cidade é refletir sobre o urbano como estratégia de poder. Nesse sentido, pode-se analisar desde os espaços criados para isolar pessoas com doenças transmissíveis até pessoas antes consideradas perigosas, como mendigos, idosos, portadores de transtornos mentais, etc. Concepções diferentes sobre o processo saúde/doença modificam os espaços, como os contidos na reforma psiquiátrica que 
possibilitou a abertura de manicômios que isolavam seus moradores do convívio social, silenciando os questionamentos sobre as estruturas sociais vigentes, produtoras de transtornos mentais e afastamento (exclusão) social. Do mesmo modo, as descobertas de novos medicamentos possibilitaram reorganizar espaços, evitando a existência de colônias de pessoas portadoras de tuberculose, de hanseníase. A doença, ao não respeitar fronteiras, além de manipular espaços, manipula trânsitos de pessoas, evitando que seja transportada de uma região para outra através do corpo doente.

CZERESNIA e RIBEIRO (2000) demonstram como a existência de doenças transmissíveis levou a objetivação dos espaços, criando termos como doença epidêmica e endêmica. Assim, uma pergunta médica se torna essencial durante os diagnósticos clínicos: em que lugares o paciente andou. A associação entre doença e espaço geográfico se torna tão fixa que leva a condenação, como a associação da região norte do Brasil com malária, do nordeste com desnutrição, o centro-oeste com febre amarela, o sudeste com violência, a estrutura do corpo humano às doenças transmissíveis. Além disso, associa-se a periferia das cidades como causadoras de poluição do meio ambiente, de serem violentas, ocorrendo individualização de culpas, não possibilitando interdependências sociais e espaciais e reafirmando preconceitos e discriminações. CZERESNIA e RIBEIRO (2000) baseando em SANTOS (2004) nos dizem como a globalização levou a um maior deslocamento do ser humano, expondo maior visualidade das desigualdades e diferenças socioeconômicas, uma vida direcionada para o consumo imediato e pela degradação ambiental. O espaço de acordo com SANTOS (2004) é visto como meio técnicocientífico-informacional, uma técnica que transforma a natureza, estruturados pelos processos econômicos e sociais. Portanto, através da interação entre ser humano e espaço, promove-se uma dinâmica que faz tanto um como outro se modificarem dinamicamente.

A cidade já não se resume numa relação centro/periferia, dividi-se por focos de poder e resistência. O centro representa só mais um poder, que pode ser simulado em diferentes partes da cidade. Um shopping-center, um hospital, um centro 
comercial pode configurar um novo bairro. A igreja, antes vista como ponto central, hoje se perde para os aglomerados de lojas comerciais. A cidade medieval, com seus palácios cercados por muralhas, remete às novas casas da população abastada, cheias de apetrechos tecnológicos como cercas elétricas, câmeras, interfones e os guardas noturnos, com suas motocicletas apitando preventivos durante toda a noite. São as novas configurações dos bairros elitizados, com ruas largas, casas de muros altos, trancando a sociedade fora de seus espaços. As casas mais pobres, apertadas, receptivas, transparentes, são ironicamente vigiadas como um perigo, fazendo o bairro tremer quando a polícia passa, como uma metáfora da extensão dos muros, câmeras e cercas elétricas daquelas casas luxuosas. Algumas casas de bairros populares, quando se afeiçoam com os ditames elitizados, improvisam com um buraco na parede, servindo para o medidor de eletricidade olhar o relógio e para simular um interfone. Através destes buracos improvisados, iniciei algumas de minhas entrevistas, tentando apalpar um diálogo cheio de receio. Como exemplo, pode-se ver esses "interfones improvisados" nas casas da COHAB, como mostram as fotos seguintes.
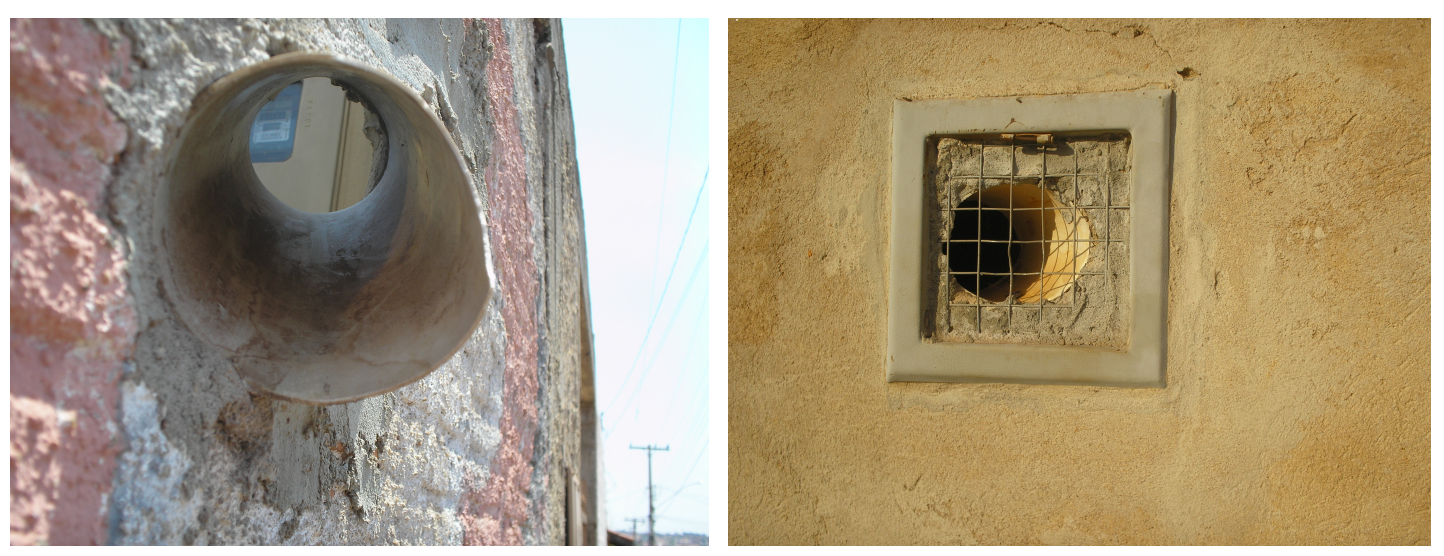
4.1.2 Do desenvolvimento agroindustrial ao comércio de produtos farmacêuticos

A cidade de Ribeirão Preto é considerada pólo do desenvolvimento econômico do que chamam de "oeste paulista" (regionalmente o município fica localizado na parte nordeste do Estado de São Paulo), a qualidade da terra e a grande produção de laranjas, cana-de-açúcar e seus derivados fizeram da região um destaque nacional.

Localização geográfica de Ribeirão Preto:

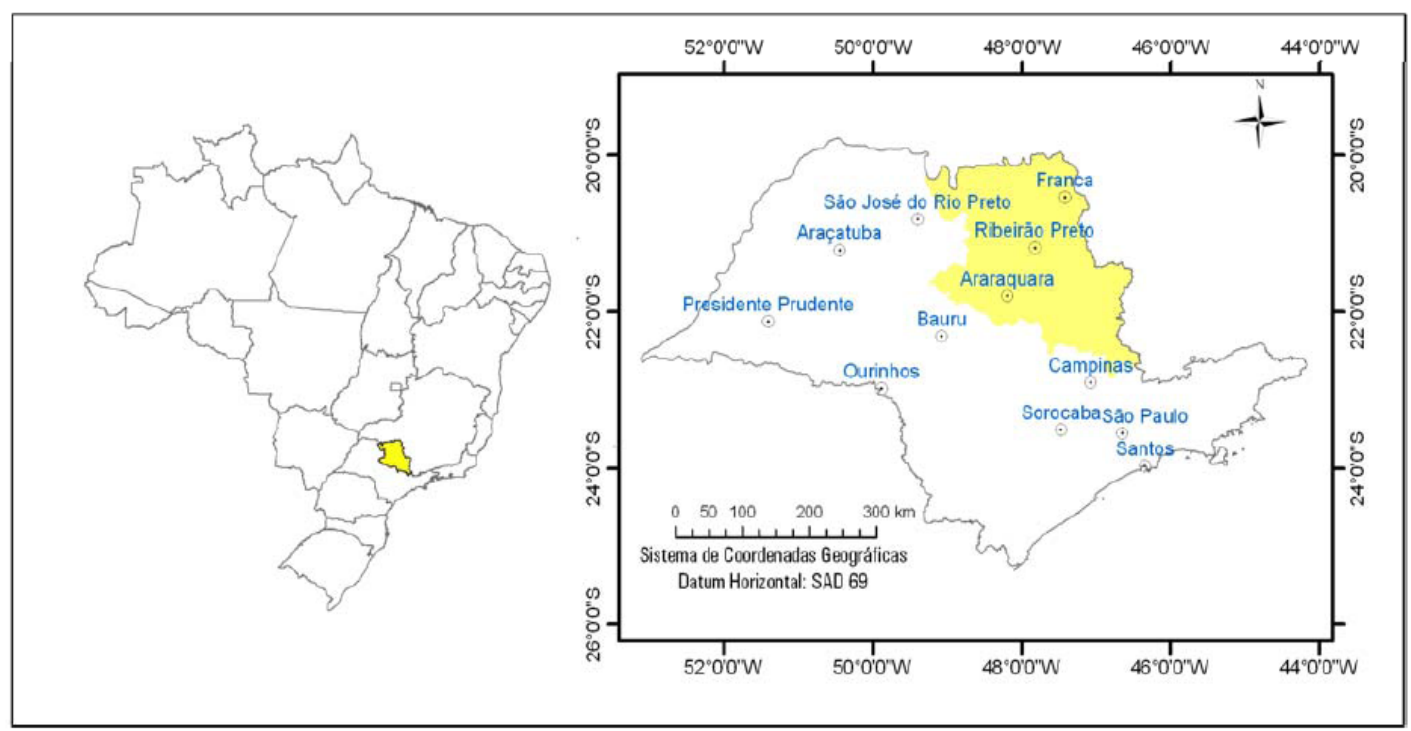

Fonte: QUARTAROLI e col. (2006)

A cidade de Ribeirão Preto tornou-se central frente a uma região que engloba outras cidades menores que a circunvizinham. Além disso, o Hospital das Clínicas, localizado em Ribeirão Preto, é considerado referência nacional em muitos 
tratamentos e pelo elevado número de pesquisas quando comparado com outros centros de pesquisa médico-hospitalares.

Assim, a cidade, ao se tornar destaque como opção ao desenvolvimento econômico e científico, faz com que cidades vizinhas se tornem muito próximas em termos de mercado consumidor. São os visitantes dos shopping-centers: a cidade torna-se ponto de encontro e de consumo. Ocorre a busca por melhores trabalhos e condições de vida de uma população vinda de outros Estados brasileiros e do interior do próprio Estado de São Paulo, assim como o trânsito de estudantes de graduação e pós-graduação, principalmente na área de saúde, pela concentração de cursos nessa área se concentram na Universidade de São Paulo e em outras instituições de ensino. E também são os inúmeros tratamentos médico-hospitares que fazem a cidade ser escolhida pela população nacional e do Estado na busca de tratamentos de doenças.

Nesse sentido, focalizei como o mercado farmacêutico se estrutura através dos serviços de saúde como hospitais, centros de saúde, clínicas particulares, farmácias e drogarias. Este mercado pode ser relacionado com a expansão da população que se direciona para a cidade como ponto central do consumo de mercadorias: Ribeirão Preto possui na atualidade mais de quinhentos mil habitantes, mas a microrregião (composta por Ribeirão Preto e mais 15 municípios que circunvizinham) possui cerca de um milhão de habitantes. Este mercado é também reflexo dos que SANTOS (2004) chama de meio técnico-científico-informacional, o espaço é ordenado pelas ações crescentes da ciência, da tecnologia e da informação.

Nesse sentido, ELIAS (2003), tendo como referência o trabalho de SANTOS (2004), revela como a região de Ribeirão Preto se torna palco de um espaço globalizado através do complexo agroindustrial sucroalcooleiro, levando a divisões territoriais, ao deslocamento de mão-de-obra considerada volante, utilizadas de acordo com o ciclo de plantação e colheita, contribuindo para o desenvolvimento do comércio, serviços e indústria, destacando Ribeirão Preto principalmente pela produção de cana-de-açúcar e pela produção de combustível. Portanto, Ribeirão Preto está marcada pelo uso de tecnologias e técnicas para a produção de mercadorias e manipulação da vida social, levando ao desenvolvimento de comércio 
voltado para a mão-de-obra utilizada na produção, de um complexo industrial que transforma a matéria-prima e produz maquinarias e equipamentos para produção e mudanças do espaço, induzindo a movimentação e construção de mecanismos para a escoação de mercadorias, descobertas científicas para este fim.

Assim, todo este mecanismo voltado para a produção passa a ordenar a vida cotidiana da população envolvida, seja através da transformação do ambiente, geralmente marcado pela poluição atmosférica, pela fumaça dos carros e das queimadas das canas, fazendo elevar o número de doenças respiratórias, seja pelos sintomas de doenças provocadas pelo mercado de trabalho competitivo, seja pelas rupturas entre pessoas com os lugares quando são levadas a se deslocarem e a esquecerem toda uma vida passada, seja pelos afastamentos (exclusões) sociais quando não estão adaptados às novas normas e ordens do mercado de trabalho.

Apesar de meu estudo centrar no consumo de medicamentos antidepressivos e ansiolíticos a partir dos serviços públicos de dispensação de medicamentos, observei a importância da relação público/privado no consumo de medicamentos. Desse modo, enfatizei a medicalização da sociedade (consumo de serviços e produtos relacionados à saúde e com a medicina oficial) também através das drogarias: uma espécie de drogalização da sociedade que contribui na representação do consumo de produtos farmacêuticos independentemente dos serviços médicos (farmaceuticalização). É importante enfatizar que o consumo de medicamentos é construído numa relação entre o público e o privado pela indústria farmacêutica.

O comércio de medicamentos, em Ribeirão Preto, possui uma disposição espacial de acordo com os bairros das cidades. Na parte central e em suas proximidades estão várias drogarias, lugares geralmente marcados por alto fluxo de pessoas e por bairros residenciais abastados, revelando que o consumo de medicamentos se aproxima mais de uma relação comercial do que a promoção de saúde, prevenção e tratamento de doenças. De acordo com CALIL JÚNIOR (2003), no centro de Ribeirão Preto ocorreu, desde sua fundação, imposições socioeconômicas que levaram a três processos relacionados à estruturação da cidade: 1) substituição do centro como uso residencial pelo uso comercial, criando novos 
aspectos visuais como as fachadas comerciais, vitrines, lojas especializadas, estacionamentos, etc; 2) diversificação do comércio e sua relação com o transporte ferroviário; 3) Separação entre local para o comércio de luxo e para o comércio popular. Acredito que estes processos podem ser inferidos para grande parte das cidades brasileiras.

É dentre esses processos que também se nota a particularização do comércio de medicamentos presentes nas inúmeras drogarias e farmácias. As drogarias estão espacialmente distribuídas de acordo com as disposições socioeconômicas. Destacam-se dois tipos de drogarias: as de bairro e as do centro, diferentes tanto em sua estrutura física como na forma que seus funcionários se apresentam e pelos medicamentos comercializados. Os funcionários das drogarias também contribuem nesta diferenciação, sendo escolhidas as drogarias centrais como lugar almejado para o trabalho por serem consideradas mais respeitadas e com maiores possibilidades de ter um melhor salário quando comparadas com as drogarias periféricas, dos bairros. A diferenciação das drogarias de bairros com as centrais não é uma diferenciação que provoca olhares diferentes quando se trata de normas a serem seguidas, observei que a distância do centro possibilitava a estas drogarias ganharem uma nova roupagem que não seria permitida em outro lugar, vendendo produtos considerados proibidos no centro, como os relacionados ao gênero alimentício, e com falta de espaço para aplicar injeções. As drogarias da região central de Ribeirão Preto são destacadas pelo seu número elevado de estabelecimentos, pela sua apresentação que destaca as ofertas de descontos nos medicamentos revelando a competitividade por clientes.

Nas regiões centrais, a quantidade de drogarias é tamanha que se pode notar entre uma esquina e outras várias drogarias, entre poucos quarteirões a existência de mais de uma drogaria que fica aberta por vinte e quatro horas. Além disso, verifiquei que no centro estavam presentes as grandes redes de drogarias da cidade, estando às vezes duas drogarias concorrentes uma ao lado da outra ou que numa aproximação de cerca de cem metros possui três lojas da mesma rede, sendo às vezes uma em frente à outra. As drogarias, procurando concorrer e buscar locais de grande fluxo de carros e pessoas, se localizam na região central e nas principais avenidas da cidade, 
juntamente com bancos, clínicas e laboratórios clínicos particulares, como na avenida 9 de Julho, o que condiz com CALIL JUNIOR (2003), ao notar que os eixos comerciais se expandem pelas redondezas das principais ruas ou avenidas com alta concentração de comércio.

Geralmente, as drogarias nesse local estão marcadas pela presença excessiva de propagandas e de frases que marcam o consumo de medicamentos na atual sociedade como: "longevidade", "qualidade de vida", "menor preço", "cobrimos oferta", "economize até 70\%", etc. Além disso, algumas drogarias aproveitam a mudança do perfil epidemiológico fazendo propagandas específicas para a população idosa, como a presença de cartazes sugerindo que ali o idoso é bem visto, alegre e terá economia especial quando comprarem seus produtos. São nessas drogarias que os transeuntes dizem encontrar todos os seus medicamentos, lugares que buscam aproximação com as pessoas de maior poder econômico. Diferentemente, nos bairros mais pobres, nas drogarias está presente uma pequena variedade de medicamentos, concentrando-se principalmente nos medicamentos de menor custo, mas que dão uma maior margem de lucro (como os similares).

Assim, a cidade possui uma dinâmica histórica ligada ao comércio privado de medicamentos. Pode-se relacionar o deslocamento das drogarias da proximidade com outros serviços de saúde para os locais com alto fluxo de pessoas a uma alta automedicação ou farmaceutização da sociedade. Pode-se notar que o fato de Ribeirão Preto ser considerado desde a sua fundação um pólo de desenvolvimento regional, fato que contribui para o desenvolvimento do comércio no centro, abertos pelos trilhos das estradas de ferro e interligação com outras cidades por rodovias, fez dessa cidade em si um "carrefour" ou, na tradução da palavra francesa, uma encruzilhada, contribuindo para o desenvolvimento de diversas universidades, de um centro comercial em que consumidores de cidades vizinhas participam do consumo de serviços médicos e de medicamentos.

Segundo CALIL JÚNIOR (2003), Ribeirão Preto assumiu e reafirmou o papel de pólo regional em três momentos: em 1920 Ribeirão Preto assumiu o papel de pólo regional com sua produção de café e seu escoamento através da Estrada de Ferro 
Mogiana; em 1950 a formação de rede rodoviária que ligou o interior paulista e ao Estado de Minas Gerais; e a partir de 1970 a implantação do complexo sucroalcooleiro. A cidade, desde sua fundação, esteve ligada ao processo capitalista e progressista da sociedade européia, pois nas lavouras de café estava presente a população em sua maioria italiana e em minoria pelos nativos, descendentes de escravos e mineiros. Na nova configuração, fruto desse novo suposto desenvolvimento, estão presentes estes e outros (goianos, paranaenses, baianos, etc.).

A nova configuração do setor farmacêutico relacionada às drogarias, em constante ligação com a estrutura da cidade, como a concentração comercial do centro ou o sentido de bairro com enfoque de população também consumidora, propicia um processo de distinção de classes sociais. Nesta população, pode-se notar a formação de um mercado constituído de lojas específicas com enfoque propagandista. Pode citar os tipos tradicionais de comércios locais como as mercearias, os botecos, os pequenos bares, os lugares de venda de lanches e as chamadas drogarias de bairro. Além disso, notei o começo de uma nova configuração, a expansão das grandes redes de supermercados e drogarias para a parte periférica da cidade ou em bairros, como as drogarias localizadas no espaço dos hipermercados $\mathrm{e}$ as redes de drogarias, fazendo os pequenos comerciantes localizados nessas regiões da cidade se preocuparem com a concorrência.

No entanto, também verifiquei a formação de uma nova estrutura das drogarias na parte central de Ribeirão Preto e nos bairros com concentração de população aparentemente com maior poder aquisitivo: são as drogarias que se proclamam especializadas em tratamentos de alto custo. Nessas drogarias, foi possível verificar estruturação diferente do atendimento ao cliente, com a permanência de portas fechadas, devendo-se tocar uma campainha para entrar, sendo que o cliente senta em uma cadeira confortável e a/o atendente o recebe. É importante notar que essas drogarias nem sempre se acompanham de assistência farmacêutica apropriada, mas de luxo diferenciado no atendimento como enfoque estratégico para a venda, como disse um dos gerentes. Em outra drogaria, observei a existência de uma pequena sala de recepção em que fica à disposição uma televisão 
de tela plana e alguns sofás confortáveis. Outro fator notado nessas drogarias é a anulação do balcão como divisória dos produtos e do comprador, o cliente se senta como se tivesse entrado numa espécie de mostruário medicamentoso, e o antigo balconista se transforma em atendente. Os produtos estão também modificados quanto à estratégia comercial e do público selecionado, e apesar se dizerem mantenedores de um estoque diversificado para todo tipo de patologia, direcionam o atendimento para pacientes em uso de tratamentos onerosos, como os antineoplásicos, e que tratam em clínicas particulares. Outro tipo de drogaria especializada, mas com porte menor do que as anteriores são as drogarias com enfoque nos pacientes diabéticos, com uma linha relacionada aos produtos nutricionais específicos e medicamentosos. Elas são pequenas drogarias e se dizem portadoras de atendimento com maior proximidade com os pacientes, podendo, até em horários em que estão fechadas atender os clientes conhecidos.

Um novo formato de drogaria que notei foi a associação entre hospital privado e drogaria, fazendo em si propaganda para os hospitais a que estão ligados e aos convênios médicos relacionados a seus serviços prestados, enfatizando o desconto especial em medicamentos prescritos por seus médicos. Este desconto faz com que essas drogarias sejam muitas vezes temidas por outras drogarias. A aparência interna é de uma drogaria comum mas, diferentemente das drogarias de rede, apresentam poucos produtos para fora do balcão e quase não vendem medicamentos similares, restringindo-se aos de referência e alguns genéricos, o que mostra uma relação intensa entre laboratórios farmacêuticos e prescritores.

Nessas drogarias, nota-se aparência externa diferente das grandes redes localizadas no centro, com ausência de propagandas, de folhetos e cartazes. Nas drogarias ditas especializadas pode-se também verificar poucas propagandas de descontos, a negociação sobre o medicamento é realizado de forma especializada, individualizada por seus vendedores.

Como BOURDIEU (2007) retrata, a aparência, os gestos e as posturas relacionadas ao habitus, modo como a sociedade se mostra, pode notar que o vestuário dos funcionários muda de acordo com a drogaria e o meio em que está 
inserida. Nas localizadas em setores mais ricos observa-se um uniforme e uma aparência mais exigida por suas organizações, diferente do que se nota nas drogarias de bairros populares, em que o próprio proprietário geralmente é quem recebe os clientes, quase todos já conhecidos.

Por um lado, a dicotomia entre bairro/centro e sua relação com as drogarias é também reflexo da população que circunvizinha. Por outro lado, pode-se notar pontos relacionados à medicalização como um todo, porém não se pode esquecer as particularidades de cada bairro. Dentre os pontos considerados que abrangem toda a cidade, pode-se notar a enorme quantidade de serviços médicos e a sua popularização, como os cursos desenvolvidos pelo campus da Universidade de São Paulo (USP) em Ribeirão Preto, considerado centro de pesquisa e referência na área médica com grande impacto sobre os meios de comunicação, desde os científicos aos populares como a televisão, revistas revelando serviços e produtos da medicina (descobertas, pesquisas e publicidade através de artigos científicos, jornais impressos, programas de televisão e revista) e outras diversas faculdades: medicina, fisioterapia, enfermagem, nutrição, farmácia, odontologia, física médica, terapia ocupacional, entre outros cursos.

É bom lembrar que o campus da USP é ocorrido de um desmembramento de uma fazenda de café e que o ponto primordial foi a sua transformação em $1934 \mathrm{em}$ Escola Prática de Agricultura e a criação da cidade universitária, mas que preserva o velho, a tradição do trabalho e os novos prédios como o do Hospital das Clínicas, fruto de molde fáustico (as tecnologias e o progresso científico suplantam o ser humano) (SIBILIA, 2003). De acordo com CALIL JUNIOR (2003), a polarização da cidade é também conseqüência deste campus e do surgimento de três shoppingcenter e hipermercados. De acordo com este autor, programa como o pró-álcool contribuiu para o desenvolvimento desse comércio e aumento da população. E a mecanização da colheita de cana de açúcar contribuiu para o desemprego na cidade e queda do crescimento populacional depois de 1990 e para a população tornar-se quase em sua totalidade urbana $(99,6 \%)$, sendo que, do total da população economicamente ativa, apenas $3 \%$ trabalhavam na agricultura, enquanto $83,1 \%$ no 
comércio e serviços e 13,9\% na indústria. De 1980 a 2000 verificou que a COHAB RP (Companhia Habitacional de Ribeirão Preto) contribui para a expansão da cidade.

HOCHMAN (1998) revela como o Estado de São Paulo, desde o início do século XX, esteve expressivo nas imposições políticas que serviram para desencadear o processo de medicalização. Desse modo, pode-se verificar a migração em busca de cura de doenças para regiões que se desenvolveram no aspecto que condiz às estruturas médico-hospitalares. As caminhadas por migrantes em busca de tratamentos não são restritas aos dias de hoje. As investidas através de uma política sanitarista no Brasil contribuíram para dividir o país em sertão, quase sempre visto como cheio de doenças, fracassos e pobreza, e no progresso que pregava a região sudeste, principalmente por São Paulo e pelo litoral (HOCHMAN, 1998). Dizer sobre migração para o Estado de São Paulo não se relaciona a uma migração somente baseada na busca de trabalho, mas a uma busca pela proximidade com a ciência, com serviços de saúde que possibilitem os melhores tratamentos. Nesse sentido, a cidade de Ribeirão Preto se destacou, podendo-se ver as inúmeras pessoas que ali chegam para fazerem cursos de pós-graduação, graduação e para tratarem suas doenças por ser ali um lugar de referencia nacional.

Ao mesmo tempo em que se criavam divisões entre sertão e litoral, as divisões como urbano e rural, entre centro e periferia, entre interior e capital, marcas de uma separação dualista que acompanha o desenvolvimento científico, marcador de discriminações e distinções, seja pelo acesso aos carros de luxos, casas, seja pelo acesso às tecnologias relacionadas ao setor saúde. São posições dualistas que colocam o processo de medicalização a se confundir com o progresso científico, misturando consumo com qualidade de vida. Contudo, segundo HOCHMAN (1998), as divisões geográficas são problematizadas em decorrência de as doenças contagiosas não respeitarem estas divisões, colaborando para as definições de políticas no âmbito nacional relativas à vigilância sanitária e epidemiológica. As doenças, quando analisadas como definidoras de regiões, como a febre amarela e a malária, produzem significados preconceituosos, relacionando à pobreza e à falta de "progresso". A periferia, rural, sertão, ganha conotações que, ao serem relacionadas 
com pobreza, leva a ser chamada também de regiões doentes, em que seus moradores são considerados culpados, levando a não problematizar os conflitos envolvendo desigualdades sociais. Essas divisões entre regiões também são aproximadas das diferenças entre os moradores, criando fronteiras imaginárias entre ruas (exemplo, ruas de asfalto e de terra), entre bairros, entre os sexos, entre casas, entre classes sociais, entre serviços de saúde. Nesse sentido, quando se diz sobre descentralização dos serviços de saúde, deve-se também contextualizar as inumeráveis fronteiras que são socialmente criadas, sejam elas expressas através do corpo e de suas aparências, de seu habitus, sejam elas criadas a partir das desigualdades socioculturais. Nesse sentido, os moradores dos bairros entrevistados foram enfáticos em dizerem que um dos principais motivos de morarem ali eram os serviços de saúde ali disponíveis, sejam os relativos ao Centro de Saúde Escola (CSE), sejam os relativos ao Hospital das Clínicas da USP, sendo a localização dos bairros entre os dois serviços.

\subsubsection{Medicamentos e a produção da distinção}

Foi possível observar como os serviços de saúde e o consumo de medicamentos contribuem na organização dos espaços de uma cidade. Além disso, pode-se aprofundar sobre uma questão atualmente destacada: a dependência ao plantio de cana-de-açúcar e as transformações das cidades.

As divisões entre serviços de saúde refletem os diferentes grupos sociais de uma cidade. Entre as divisões contemporâneas pode-se fazer referência ao que ELIAS e SCOTSON (2000) diz sobre o que são "estabelecidos" e "outsiders", uma relação de distinção envolvendo privilégios historicamente construídos de um grupo social em relação ao outro, o que é reafirmado constantemente pela estigmatização dos "outsiders" como inferiores. 
Imiscuído aos transtornos financeiros, pode-se observar uma rivalidade que ocorreu entre os moradores de duas partes dos bairros pesquisados, chamada por muitos moradores de "guerra das favelas". Os moradores considerados antigos, referindo-se a um "nós", ao esteriotiparem os grupos envolvidos na "guerra" como "gente ruim, que não é de confiança", taxando-os como "eles", se diziam como "gente boa", diferenciada. Esta rivalidade foi justificada como motivo para o consumo de medicamentos antidepressivos e ansiolíticos, devido ao medo da violência e a morte de seus moradores. Alguns moradores disseram que o principal motivo da "guerra" foi por causa de um tênis, um perfume e drogas, levando aos atritos entre as duas comunidades, desencadeando mortes.

A "guerra" não se restringiu aos poucos moradores envolvidos, toda pessoa moradora das partes em "guerra" sofreu um processo de identificação. Os preconceitos são referidos ao habitus, numa união entre lugar de origem, cor e relacionados ao trabalho e ao tipo de lazer. E os diferentes grupos procuraram definir uma hierarquia de perfeição, um estágio que definisse um sentido moral acima do outro. As relações de poder entre grupos sociais reafirmam diferenças que vão desde a aparência física até questões socioculturais como o vestuário, alimentação, modos de vida, etc, como explica ELIAS e SCOTSON (2000):

"Esse problema coloca prontamente em foco o longo processo durante o qual os grupos humanos se desenvolveram em diferentes partes da Terra, adaptaram-se a condições físicas diferentes e, mais tarde, após longos períodos de isolamento, entraram em contato uns com os outros, não raro como conquistadores e conquistados e, portanto, dentro de uma mesma sociedade, como estabelecidos e outsiders" (ELIAS e SCOTSON, 2000, p. 46).

Como VIANA (2007) diz, mesmo em um ambiente, como no Brasil colonial, em que a miscigenação era vista ora como produto que fortalece o povo e adapta-o ao meio ambiente, ora como enfraquecimento moral e psíquico, gerando um racismo biologizante, há o preconceito baseado na ancestralidade e do lugar social ocupado. Segundo esta autora, entre os séculos XVII e XVIII surgiram confrarias ou irmandades cristãs dos que se denominavam pardos, que procuravam dar sentido de positividade e diferenciação aos mulatos, considerados impuros e posicionados em 
um vazio entre as raças. Assim, os pardos estabeleciam limites, fronteiras em relação aos não incluídos nas irmandades, sendo fronteiras simbólicas reafirmadas pela instituição de preceitos morais e de honra, evitando serem confundidos com os mulatos, considerados ociosos, sem honra, não confiáveis. O uso da palavra "pardo" no lugar de "mulato" ou "mestiço" levava a uma barreira simbólica, visto que até os descendentes de africanos nascidos no Brasil poderiam ser classificados pelos registros paroquiais como pardos. Foi através de irmandades religiosas que alguns pardos possibilitaram a descrição de tipo ideal miscigenado, positivado, aproximando dos ideais morais impostos pela igreja e pela elite. Do mesmo modo, notei, na periferia de Ribeirão Preto, que as pessoas ligadas a uma religião se diziam diferenciados do restante da população local. Porém, mais exigentes do que as irmandades descritas por VIANA (2007): "Em outras palavras, ser membro de uma irmandade não excluía a possibilidade de estar nos calundus, de portar uma bolsa de mandinga junto ao corpo, nem tampouco de manter uma relação de veneração afetivizada com os santos de devoção" (VIANA, 2007, p. 102). Estar associado tanto a uma irmandade religiosa do passado quanto às igrejas de hoje, além de possibilitar prestígios sociais, aproxima das propostas dos poderes sócio-políticos.

A população, quanto mais distante do ideal europeu, mais impura e contra o progresso da nação fora considerada nesse período. A mestiçagem tornava o país, segundo alguns dos principais intelectuais do final do século XIX e início do XX, como entrave ao desenvolvimento, fazendo supor que estaríamos salvos com o branqueamento da raça (DIWAN, 2007). Nesse contexto, a sexualidade aviva-se nas discussões, ora aplaudida por fazer o encontro entre diferentes raças e promovendo a anulação de conflitos, ora visto como o fracasso nacional relativo ao desenvolvimento social e econômico.

Igualmente, observei que quando se diz "lá também tem gente boa, não é só ruim não", ou que "ele é um preto bom", ou :"tudo ali não presta", estão construindo um tipo ideal de pessoa, fazendo surgir grupos sociais que se dizem enquadrarem nestes ideais. Esses tipos são moldados também pelos conflitos de gênero e classe social. Assim, as igrejas protestantes têm sobre a periferia papel essencial na 
produção de diferenças, fabricando "iguais", aliados aos preceitos de honra, de um bom marido, filho e esposa.

A ascendência se torna relevante nos diálogos feitos com a proximidade européia pelas pessoas de pele branca. Segundo VIANA (2007), aparência física e sangue são conotativos de divisões e que no século XIV, filhos de judeus e mouros com espanhóis e portugueses não podiam assumir cargos públicos e quando eram admitidos em cargos considerados importantes, o seu posto era questionado, e quando aceitos, deveriam provar feitos de bravura. Os considerados "sangue sujo" eram freqüentemente excluídos, evitando uma possível ascensão social e mantendo uma estrutura social vigente mesmo quando libertos. Assim, "o estigma do 'sangue mulato' disseminou-se pelo corpo social entre os séculos XVII e XVIII, quando mulatos e mulatas passaram a ser freqüentemente identificados como desordeiros, soberbos ou inadequados para as posições sociais que eventualmente ocupassem" (VIANA, 2007, p. 123). Ser pardo significava possuir uma simbologia tanto na aparência com um novo vestuário, quando mais honrados e purificados e perfeitos, acarretados e mantidos pelos prestígios sociais, o pardo conseguia não mais ser um mulato, sinônimos transformavam-se em antônimos, garantindo a "pureza do sangue" através dos benefícios sociais. A relação entre pardo e mulato no período colonial através das irmandades contribui para se pensar, além dos papéis de igrejas nas periferias das cidades, se as políticas afirmativas não estariam afirmando discriminações frente aos não inseridos em um sistema que deveria diminuir desigualdades sociais e no percurso histórico e social de cada pessoa. E se não estaria sendo reafirmado um tipo ideal construído historicamente por instituições que valorizavam os ideais europeus, produzindo desigualdades sociais e discriminações aos não inseridos, produzindo novas fronteiras.

Como MARTINS (1997) relata, o termo "fronteira" não se resume aos espaços geográficos, pois são os limites que separam diferentes grupos sociais, marcados por confrontos, conflitos e descobertas, lugar simbólico em que poder e resistência estão presentes, marcados por derrotas, vitórias e transformações. $\mathrm{Na}$ fronteira as diferenças se tornam nítidas, o Outro é notoriamente visto, revisto. A 
fronteira representa os limites históricos do humano, divisões entre culturas, visões de mundo, espaços, barbáries (MARTINS, 1997). Este autor mostra como a luta por territórios, na segunda metade do século XX, entre indígenas, grileiros, posseiros, pequenos e grandes proprietários de terras constroem fronteiras, que favorecem os que pela proximidade dialogam com a possibilidade única do progresso, pelo desenvolvimento econômico, e com os poderes envolvidos, inclusive com a Universidade, que focaliza os registros sobre a fala destes, esquecendo dos subjugados. Do mesmo modo, quando analisei o consumo de medicamentos, observei que os registros da relação entre medicamento e sociedade ficaram restritos aos serviços de saúde, esquecendo do cotidiano e das particularidades do consumidor frente ao seu dia-a-dia. E o consumo de medicamentos está envolvido nos conflitos nas fronteiras, surgidos também nas relações de gênero, de classe social, de modo de vida. São nas fronteiras que as contradições e conflitos surgirão, promovendo acordos e desacordos, encontros e desencontros envolvidos pela dinâmica entre poder e resistência. Portanto, trata-se de mais um ambiente de fronteira, o que denomino de fronteiras no urbano, conflitos que separam grupos sociais e transparecem divisões da cidade, fronteiras que produzem e são produzidas pelo habitus. A divisa de uma favela com outros bairros ou um pequeno grupo social que distingue de uma suposta lógica que o condena pode representar uma fronteira. A fronteira torna-se lugar de encontro e desencontro entre os bairros, diferenciando os que vêm de fora, os dali, os do norte, os mineiros, os goianos, ora unindo-os pelo olhar de um outro, ora distinguindo-os entre si.

Trato da fronteira em outro contexto do descrito por MARTINS (1997), abordando os desdobramentos das fronteiras, a permanência de conflitos, não conseguindo ver a anulação total da fronteira como a descrita por MARTINS (1997): "A fronteira só deixa de existir quando o conflito desaparece, quando os tempos se fundem, quando a alteridade original e mortal dá lugar à alteridade política, quando o outro se torna parte antagônica do nós" (MARTINS, 1997, p. 151, grifos do autor). Acredito que ocorrem domínios, coerções que simulam homogeneidade, passividade, controle, mas não a anulação dos conflitos, pois sempre dentro de um "nós" há um 
“eu", um outro que estrategicamente procura o poder. Assim, persistem conflitos provenientes de encontros culturais desde a chegada européia no Brasil. É no jogo contínuo entre Poder e Resistência que as fronteiras são redefinidas, moldadas, desmembradas, criadas, recriadas. Não somos totalmente dominados pelo Outro, no entanto, pode-se se formar um Nós mutável. É também neste "Nós" que os conflitos são preservados. A interação entre culturas não anula o surgimento de conflitos, eles são remodelados, formando novos atritos, novas fronteiras. Dominar o Outro é anular respostas, mas não o conflito, pois um suposto "dominado" pode silenciosamente dominar, mas modificado pelo Outro. Assim, no conflito há interação. São nas relações de gênero, classes sociais, entre gerações, entre modos de vida que os conflitos persistem.

MARTINS (1997), ao descrever fronteira como ambiente envolvendo pioneiros e expansionistas na transformação do espaço, das terras, pelas elites agrárias frente os indígenas e pequenos agricultores, nos diz que está presente o processo de modernização, transformação e criação do novo através do mercado e das relações sociais, que além dos deslocamentos da população aos novos territórios há um processo de transformação social, de mudanças de concepções e modos de vida. Ao tratar do urbano, acredito na existência similar deste processo de transformações espaciais e sociais, que persiste nos deslocamentos da cidade contemporânea em que se perde a limitação geográfica. A cidade caminha como pioneira relativa ao campo. Os bairros são construídos e remodelados, formando uma complexa rede de relações internamente e entre os bairros, entre centro e periferia, entre classes sociais e entre moderno, tradicional e contemporâneo. Freqüentemente, como encontrei, numa nova favela surgem pequenos grupos de pessoas facilitando a vinda de outros moradores, podendo ser parentes, amigos ou pessoas em situações e percursos de vida semelhantes ao que vieram primeiro, alguns até deslocados de outras favelas. Como MARTINS (1997) mostrou no campo, na cidade existem também os pioneiros e os expansionistas, os primeiros ordenados por uma lógica racional econômica e os segundos como ampliando e formando sistema de crenças, de vínculos e valores. 
Possui a cidade sentido progressista em que constantemente chegam produtos novos para serem consumidos, vendidos, em que se reafirma o mesmo sentido dado pelos primeiros ocidentais chegados ao Brasil: a imposição de uma suposta ordem voltada para a produção de mercadorias e exploração do meio ambiente e de populações subalternas, subjugadas, desde as primeiras invasões pelos considerados desbravadores, pelos expansionistas, partindo ruma ao além-mundo, não urbanizado, desconhecido pela lógica ocidental que transforma o barro em asfalto, a vegetação nativa em um complexo agroindustrial. A luta contra o campo ainda persiste no ambiente urbano.

Assim, vi na favela e em pequenos grupos de moradores a criação de galinhas, pequenas hortas, animais como cavalo, carneiro, etc, desconfigurados de seu ambiente rural e levando seus donos a criarem "ilhas rurais",

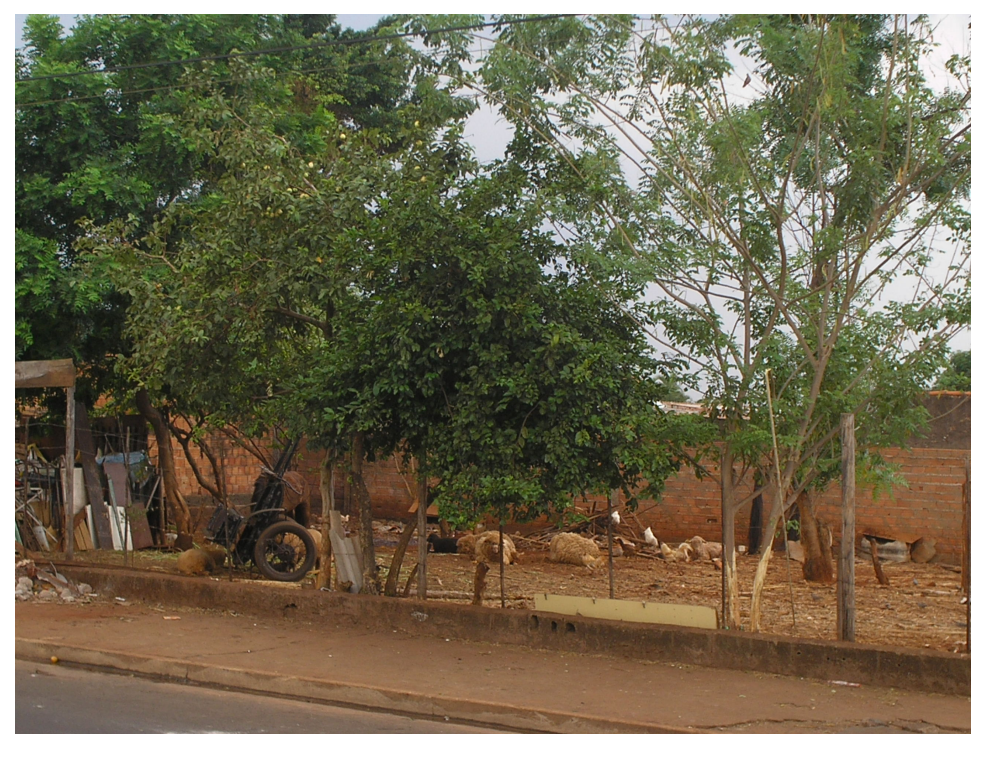
pequenos espaços que simulam uma pequena fazenda no meio da cidade. São

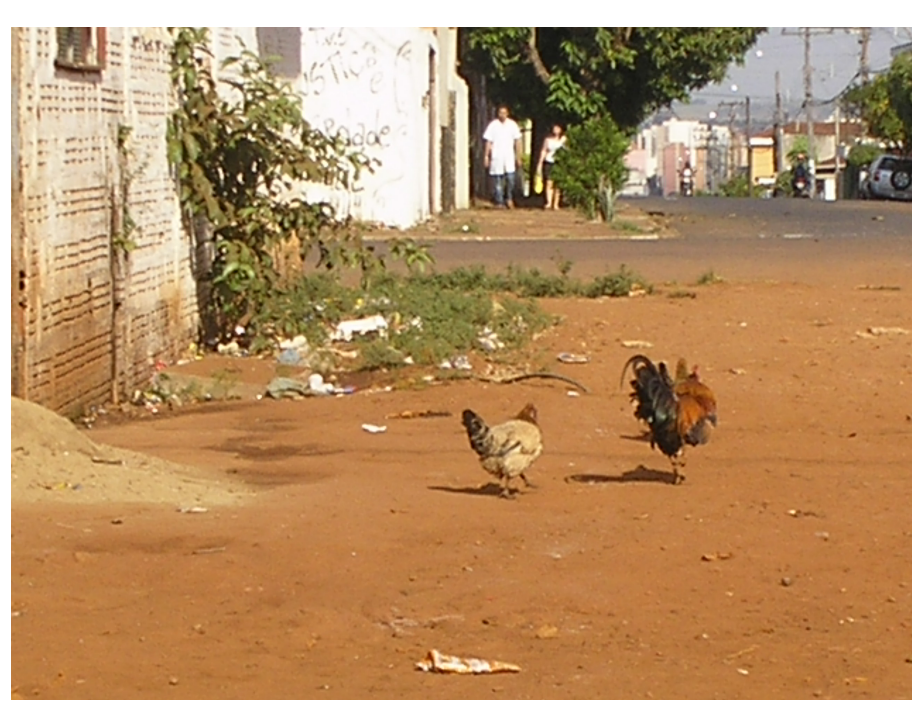
moradores que denotam à sua vida passada, lembrando de seus pais e avós, em proximidade com o meio rural (ver fotos ao lado).

Morar na cidade se torna ignorar a subsistência com a terra, ser além de produtor, um consumidor integral, saber que todos os 
produtos de que precisa para sobreviver estão em uma loja, uma mercearia, um shopping-center, um hipermercado.

O meio rural é metamorfoseado em fábrica, sua produção se torna também em série, por isso a sua mecanização: a terra deve dar contínua produção. Não somente as chaminés expelem fumaças em seu processo intensificado na produção de mercadorias, mas todo o campo queima, são as grandes extensões de plantações de cana-de-açúcar no entorno da cidade de Ribeirão Preto que são queimadas. O meio rural se urbaniza e os trabalhadores restringem a relação com a terra a um trabalho nos moldes do trabalho fabril (MARTINS, 1997). A totalidade em que a terra estava envolvida na produção de bens de consumo para a sobrevivência, exigindo flexibilidade pelas diversas tarefas que o campo exigia do trabalhador, resumiu-se a uma especialidade, cortador de cana-de-açúcar, concorrendo com as maquinarias feitas para ocuparem esta única função por ser considerada mais eficiente e barata. As pequenas fazendas ou sítios são transformados em grandes canaviais pertencentes aos donos de usinas sucroalcooleiras.

Como HOLANDA (1997) diz, a elite fazendeira tinha como morada o meio urbano. A cidade transformou-se em lugar almejado pelos agricultores, pois é na cidade que se possui um sistema de saúde, as tecnologias são recentes, tem energia elétrica, lugar prometido para os prazeres, a felicidade. A cidade se transforma em símbolo do progresso almejado, levando a polarização com o meio rural, que passa a ganhar conotação de lugar difícil para viver. O controle sobre a terra deixa de ser parte de uma coletividade e caminha para o monopólio de grandes empresas. Essa transformação do meio rural descaracteriza formas de resistência, como o uso de músicas caipiras para contar seus sofrimentos e possibilitar reflexões coletivas, rituais religiosos como festas do divino, santo reis (MARTINS, 1975), mudando para hábitos voltados para o urbano, inclusive os alimentos. Os alimentos são postos nas prateleiras dos supermercados e parecem perder seu elo com a terra e se ligam somente às fábricas. Por exemplo, o leite tirado da vaca que se ferve para beber, que faz queijo, requeijão, doce, etc, aparece como um "mistério" em uma caixa escrita “esterilizado". Do mesmo modo, os medicamentos perdem seu caráter manual, do 
uso de plantas medicinais, para ganhar uma nova aparência através dos comprimidos, injeções, supositórios, industrializados.

O urbano seria aqui uma configuração de uma lógica baseada no capital e na modernização, na imposição progressista, que afasta os considerados indesejados para execução desta lógica. Assim, os bairros populares em que pesquisei são próximos ao ambiente rural e algumas famílias disseram terem chegado ali quando não existia nenhuma casa, só o campo. A favela é freqüentemente vista como inconveniente frente às transformações da cidade, os seus moradores parecem estar em uma espécie de interstício, uma espécie de vácuo entre passado e futuro progressista, são pontos que aproximam do que MAGNANI (2002) diz: são "pedaços", não sendo nem o espaço da rua, nem o da casa, é um outro lugar, o lugar do encontro dos conhecidos, dos "chegados", formando trajetos singulares compreendidos pelos "iguais", pelos inseridos.

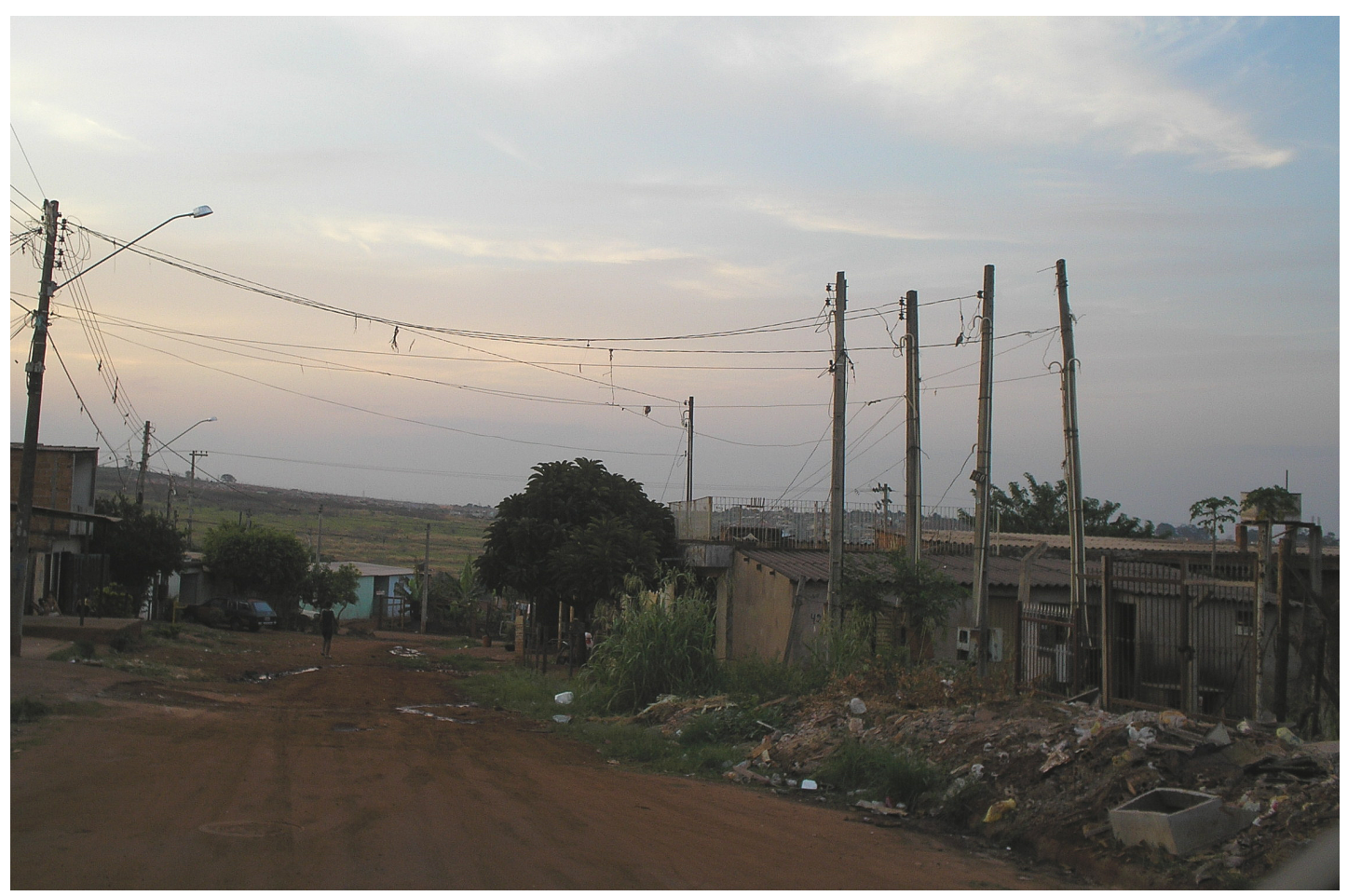


Do mesmo modo, visitei uma família de um pequeno grupo de moradores, cuja figura central é uma mulher idosa negra, que vivendo em seu terreno com filhos e netos e alguns ditos agregados, disse ter chegado ali quando "era ainda tudo fazenda". Esta família foi descrita pela população local como uma ameaça que a circunvizinhava, dizendo que ali era um "foco" de tráfico e que eram criminosos, com a exceção desta senhora. Próximo a esta família, que vive em um conjunto de casa simples e um pequeno campo de futebol, existe um prédio residencial e outras casas de moradores de maior poder aquisitivo, impondo a esta família o processo de modernização e afastamento social, sendo relatado que muitas pessoas querem comprar seu terreno, inclusive os construtores do prédio. Assim, a cidade se expande configurando grupos sociais, e é nesse ambiente de conflito que a Estratégia de Saúde da Família define seus territórios, sua área, desconhecendo muitas vezes interpretações além da espacial e do número de famílias cadastradas.

A diversidade de grupos sociais e percursos de vida, definindo identidades e modos de vida, constrói conflitos que se imiscuem com a doença e a saúde, geralmente, seguindo um padrão determinado pelos serviços de saúde. Um comprimido vai além de sua relação com a doença para o qual foi construído, ele representa todo um modelo representado pela medicina oficial. $O$ uso de medicamentos está envolto pelas redes sociais, pelos laços familiares e de amizade, marcando apoio ou resistência ao seu consumo, fazendo parte das fronteiras, dos conflitos existentes. Nesse sentido, a palavra "racionalização" e sua ação concreta como norma a ser seguida são importantes, pois racionalizar é, antes de tudo, induzir a anulação de conflitos. Desse modo, critico o termo "Uso Racional de Medicamentos", utilizados pelas políticas de saúde do Brasil (BRASIL, 2006), que é o consumo de acordo com o modelo biomédico, o uso do medicamento para uma doença em dose e hora apropriadas, sendo o seu oposto chamado de uso irracional, levando a não contextualizar o consumo de medicamentos com a vida de seus consumidores, transparecendo sentido de ordem dos serviços de saúde e não como parte de um processo dialógico e educativo. 
A busca por acesso aos serviços de saúde é também um confronto entre rural e urbano, entre o científico e o popular, entre medicina oficial e terapias baseadas em plantas medicinais. O que se fala de inclusão social estaria assim impondo uma lógica urbana e científica. Assim, as pessoas supostamente excluídas estariam ausentes em relação aos serviços de saúde, por isso dizemos afastamento e não exclusão, pois existe um distanciamento social e não uma ausência. Por um lado, afastados dos serviços de saúde por não terem acessos a estes, por outro lado, afastados dos trabalhos formais por não estarem adaptados ou disciplinados para estes, produzindo um sistema de distanciamento social que contribui para manter ou formar estilos de vida não integrados ao poder. Também, o afastamento é produto da resistência frente às coerções sociais, procurando no urbano a adaptação ao seu estilo de vida, ao seu curso de vida, aos ambientes sociais em que se constituiu. Resistência e poder estarão em contínuo conflito, criando fronteiras e divisões espaciais, e somente produzirão aceitação ou dominação de condições sociais quando homogeneizar grupos sociais e gerar silenciamento dos conflitos, mas não a sua eliminação, pois poderão ser resgatados tanto pelo poder como pela resistência no processo de dominação e hegemonia. Assim, a relação entre poder e resistência promove identificações inter e intragrupos sociais, esclarecendo habitus, levando a divergência e aproximações. Neste contexto, um policial provocará representações diferenciadas entre moradores de um bairro elitizado e de um bairro popular quando transitarem por suas ruas. A dominação de um grupo sobre o outro, não simplesmente uma coerção, uma imposição, é uma conquista histórica e social sobre o outro, uma espécie de sedução que envolve o controle sobre o corpo.

Os cuidados com o corpo são historicamente construídos de acordo com as relações de poder. Como demonstra MARQUESE (2004) sobre o período escravista, os compradores de escravos avaliavam seus corpos, seus dentes, suas canelas, seus músculos e sua destreza para possuí-los e, em seguida, procuravam ter um sistema vigilante que condizia com a maior lucratividade produzida pelo escravo, preocupando com um sistema coercitivo produtor de elo entre dono e sua propriedade. Durante o período escravista, o surgimento de manuais para saúde e de 
médicos e práticos que trabalhavam para evitarem doenças e agravos à saúde dos escravos não significou que existia uma preocupação com a pessoa do escravo, mas com a sua produção, levando-o a ser abandonado quando doente e dispendioso.

As explorações do trabalho escravo condicionam um comportamento que ainda prevalece, o trabalho bem executado e servil é adquirido à medida que os trabalhadores admitem a servidão e vantagens, condicionados por sutilezas que simulam relações familiares, de amizade, em que o serviço é realizado sem a existência de um pagamento financeiro, por isso, as relações de compadres e comadres entre proprietários das fazendas e seus funcionários. Assim, as relações entre escravo e seus donos representavam também relações de amizade, parentesco, evitando fugas e produzindo conformismo.

O limite da exploração sobre o corpo torna-se o limite da vida. Sobre o corpo do escravo é empreendida norma disciplinar, força física e humor, o escravo deve ser feliz, ter vontade de trabalhar. Assim, o suicídio é temido por seus donos. O que se supõe é que lógicas de poder sobre o outro são constantemente aplicadas, levando-as a se apresentarem como se fossem naturalizadas, imperceptíveis. Pode-se observar que o trabalhador de hoje passa por um mesmo julgamento, que vai desde sua estrutura física até seu humor, através de entrevistas, exames médicos de admissão, produzindo um falso cuidado sobre a pessoa, dissimulação do poder. Não é incomum escutarmos que a falta de um sorriso no rosto impossibilita bons empregos, além de questões relacionadas à estética e ao habitus do trabalhador.

Desse modo, de acordo com MARQUESE (2004), a relação entre escravo e seu "dono" possui uma falsa harmonia, pois a produção escrava está acima da vida dos escravos, sendo a saúde destes valorizada para a maior lucratividade. Assim, quando considerados dispendiosos, seja pela idade avançada ou por doenças, eram abandonados. MARQUESE (2004) diz que este estado de exploração sobre o escravo brasileiro foi reafirmado por laços sociais entre seus donos, no qual manuais fornecidos pelos governos sobre o cuidado com o escravo eram seguidos, catalogando os escravos e fabricando uma aparência amigável, sem conflitos, impendido confrontos colaborados por pequenas concessões ou "benefícios", como a 
alforria de alguns, utilizadas com o intuito de estender a exploração sobre outros. Além disso, os libertos se comprometiam com a manutenção do sistema escravocrata como forma de agradecimento aos ex-donos e pela distinção que adquiriam quando comparados aos não-libertos. A alforria, funcionando com uma espécie de demissão, fez-se cada vez mais freqüente à medida que aumentavam as despesas com o escravo, favorecendo um processo de afastamento social destes trabalhadores. $\mathrm{O}$ cuidado com os escravos se elevaria ao ponto de existir uma enfermaria específica.

Hoje se pode supor que ser consumidor de mercadorias simula uma equivalência à dignidade, honra, qualidade de vida, felicidade, saúde, ao bem-estar, fazendo nortear o significado de estar incluído nos "elevados" preceitos morais da sociedade. O limiar da vida se define entre o produzir e o consumir, sendo os medicamentos utilizados, além de um produto para o tratamento de doenças, como norteador desta definição. Os medicamentos colaboram para o projeto imaginário de descobrir a medida certa, supostamente alcançada quando o corpo conseguir produzir o máximo possível por um maior tempo, ser um corpo lucrativo. Os medicamentos revelam-se como objetos para aferir o corpo no processo de produção e consumo de mercadorias e a doença significa resposta e sinal de desajuste. Ora, se persiste a relação entre exploradores e explorados, pode-se verificar aparências na relação escravo/dono, mantendo os prêmios a alguns para sustentar a exploração e anular conflitos, contribuindo para julgamentos e distinções favorecedoras para alcançar o ponto máximo da produção. E para ampliar a produção, o consumo de medicamentos manipula os limites do corpo.

Medicamentos antidepressivos e ansiolíticos: apaziguar conflitos e fronteiras, além do tratar doenças. Essas fronteiras podem estar relacionadas ao corpo, às insatisfações com o próprio corpo, geralmente de uma origem preconceituosa que dita um modelo ideal. O consumo de medicamentos é visto como uma busca de ideais que não se restringem a associação medicamento-doença, um medicamento para uma doença específica. Em relação a este ponto, FOUCAULT (1987) nos diz sobre a fragmentação do corpo pela medicina ocidental, especializando o olhar sobre as partes do corpo, separando a doença do doente. Assim, era definido uma redução 
da associação medicamento-corpo-sociedade para uma medicamento-doença-doente, precisamente restrita a simples associação do medicamento a doença, sendo o doente pouco ouvido, sentido no processo de cuidar. Além disso, o medicamento vai além do corpo doente, ele molda quimicamente o corpo sadio. Este reducionismo medicamentoso faz com que se esqueça de percursos sócio-históricos dos consumidores de medicamentos, sendo considerados doentes ou não.

Nessa perspectiva, a medicina oficial é utilizada nas relações conflituosas entre grupos sociais, ora para dissimular diferenças, ora para agravá-las. Pode-se contar as inúmeras cirurgias plásticas em busca de um ideal de beleza, os inúmeros medicamentos utilizados no dia-a-dia para evitar aparências de derrota, de tristeza, de falta de vigor e força. Assim, o consumo de medicamentos antidepressivos e ansiolíticos é analisado através dos conflitos existentes na sociedade e, não especificamente, sob uma ótica que resume os medicamentos ao tratamento de doenças.

\subsection{FARMÁCIA PÚBLICA: AS FILAS DA MEDICALIZAÇÃO}

"Olha, um dia eu vim aqui, eu faço crochê, tava com uma dor, tal de bursite, sei lá, a médica perguntou o que eu era acostumada a tomar, eu falei, nem pôs a mão em mim. Ora, eu pra perder um tempão, pra ela fazer isso, é melhor a gente ir direto à farmácia e comprar o remédio e pronto. Eu não tenho tempo. O bom é que aqui a gente pega o remédio no posto" (mulher esperando a dispensação de medicamentos).

O posto de dispensação é referido como uma farmácia pública, porém, concordando com a definição de farmácia, o posto não se assemelha, pois não manipula fórmulas e comercializa medicamentos, porém ocorre uma aproximação com o de drogaria que, apesar de não ocorrer a comercialização dos medicamentos, 
ocorre a dispensação de produtos industrializados em suas embalagens originais (BRASIL, 1973). Mas, devido ao caráter popular e histórico que possui o termo farmácia, preferi chamar o posto de farmácia pública, como é chamado pelos usuários e profissionais da saúde.

A análise sobre a farmácia centrou-se pela vivência de dois olhares: um de fora para dentro da farmácia, outro de dentro para fora, procurando observar sob duas perspectivas: a dos dispensadores de medicamentos e a dos consumidores. Vou tratar

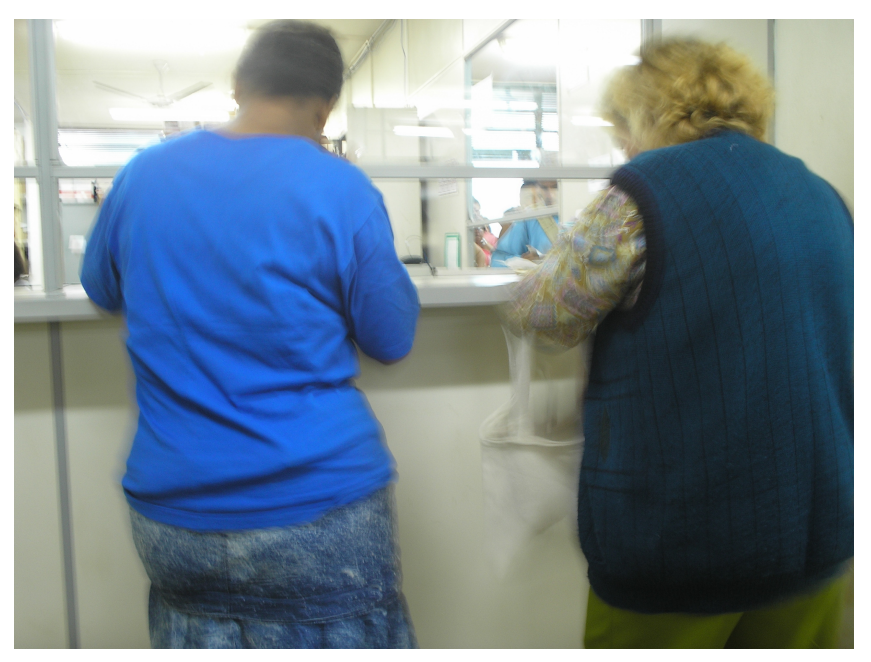
do encontro desses dois olhares, dessas duas perspectivas. Assim, fiquei nos arredores da farmácia e, na fila para pegar os medicamentos, pus-me como participante-pesquisador. Pude observar que muitas histórias, acontecimentos, são ditos na fila; uma vida pode ser ali contada, reclamada. Além disso, observei o não dito, os olhares, os ódios, rancores, amizades. A vida das pessoas se tornava transparente, sendo a fila um ponto de encontro, dizendo sobre os acontecimentos do dia-a-dia.

Quando eu dizia que estava fazendo uma pesquisa sobre o consumo de medicamentos, logo as reclamações surgiam, sobre o tempo de demora, os conflitos com o pessoal da dispensação, a exigência de um atendimento cada vez mais rápido: "embaça demais, não tenho tempo, tenho que ir ao hospital, tenho a criança, aquela mulher (dispensadora) conversa demais, Deus me livre”. A farmácia era aqui vista somente como um lugar para adquirir

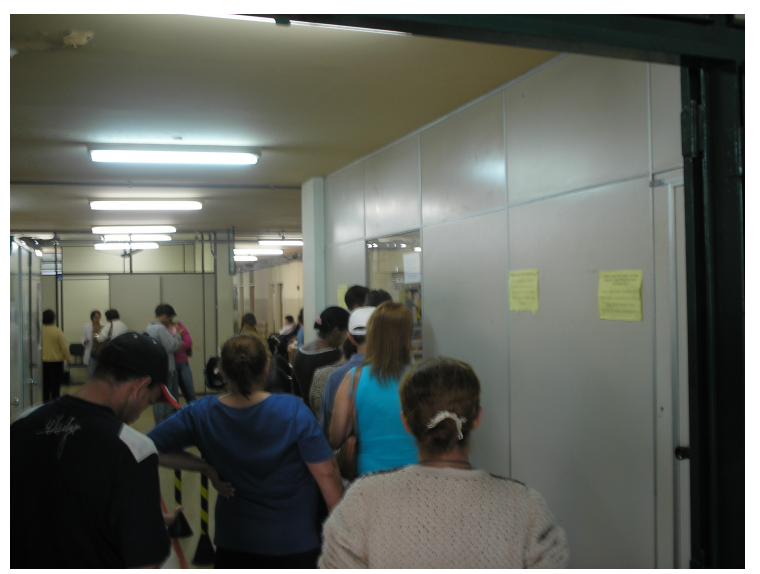


os medicamentos prescritos, não sendo vista como espaço para adquirir informações sobre os medicamentos ou lugar de educação em saúde, ocorrendo rupturas nos diálogos. Por um lado, estavam os funcionários apressados, vistos através dos vidros, por outro a exigência de rapidez por parte dos usuários do serviço, impedindo que ocorresse um diálogo efetivo, em um espaço restrito, geralmente completado por dois auxiliares de farmácia, com um estoque de mercadorias e um farmacêutico, que oscila suas funções entre burocracia e dispensação.

$\mathrm{Na}$ fila as diferenças são reveladas, mostrando a diversidade do público que vai ali para buscar seus medicamentos. São olhares divergentes, desiguais, diferentes

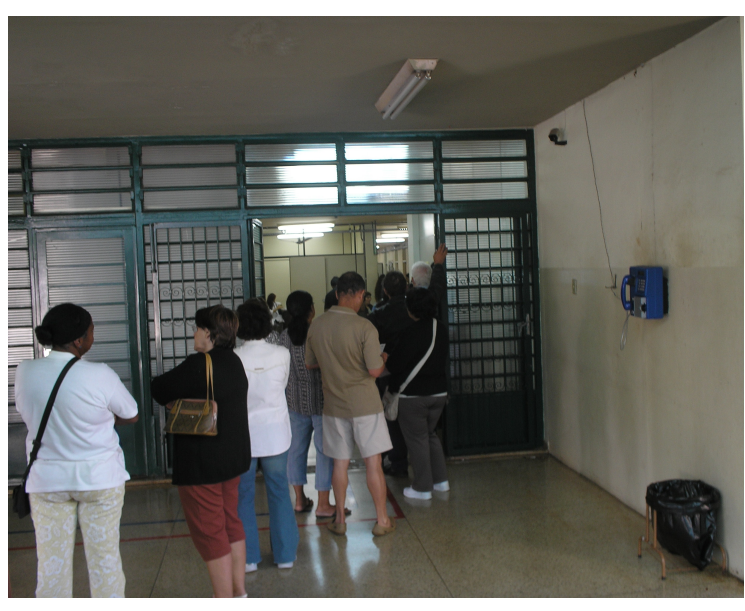
que são distribuídos pelos corredores do Centro de Saúde Escola da Faculdade de Medicina de Ribeirão Preto da Universidade de São Paulo, olhares que não são ouvidos, problematizados frente ao consumo de medicamentos, ficando restritos às ordens dos serviços de saúde. Na fila as pessoas mostram as agressões de sua vida cotidiana, a pressa de voltar para o trabalho ou de cuidar de suas casas, as mulheres preocupadas em cuidar de seus filhos, de seus maridos, preocupadas em fazer as refeições diárias da casa, de ficar à espera de filhos e maridos. Na fila a velhice ganha aspecto de doença, disputas entre idosos e doentes por quem deve ter preferência, uma disputa pelo sofrimento, marcando discursos que transparecem um curso de vida dramático: "ele colocou a velhinha para passar na frente e pegar os remédios para ele”, disse um dispensador. A fila parece ter uma vida própria: a fila fica calma, nervosa, apressada, inquieta, sem controle. A fila ri, diverte, é o lugar em que causos são contados, lugar de identificação, encontro e desencontro; as pessoas fazem amizade, falam de seus problemas durante a espera do medicamento. A fila não acaba, é eterna, como disse um funcionário da farmácia. A fila manda, quando o dispensador está só, ele pede autorização para ir ao banheiro. A fila grita e fica 
apavorada: "pacientes gritam na fila por falta de remédios e deixa os outros apavorados".

$\mathrm{Na}$ fila, os consumidores de medicamentos ansiolíticos e antidepressivos são muitas vezes identificados, facilitando um diálogo entre estes, em que avaliam os medicamentos, o tempo de uso e seus efeitos, revelando a relação do uso com a vida cotidiana, como uma senhora que me disse que usava porque seu filho havia morrido. Os diferentes usos dos medicamentos são ditos na fila. Como exemplo, lembro de uma mulher que disse ter parado de tomar os antidepressivos, mas que resolveu voltar porque estava com muita vontade de agredir seu filho depois que o marido morreu. Os medicamentos são tomados de acordo com as concepções dos pacientes. Desse modo, pude observar duas senhoras que questionavam quantos comprimidos por dia seria melhor usar e qual deles era melhor, pois já tinham utilizado vários medicamentos. Nesse sentido, os consumidores de medicamentos de uso contínuo devem merecer uma atenção que valorize não só o curso de vida, mais o curso dos tratamentos na vida dos usuários.

Alguns pacientes ditos nervosos são olhados como se fossem pacientes psiquiátricos: a fila reprime. Os pacientes psiquiátricos são também identificados pelos trabalhadores da farmácia. E muitos declaram na fila seus problemas de saúde, relatando sua vida particular para justificar os tratamentos. Uma senhora, que tomava medicamentos antidepressivos e ansiolíticos, começou a enumerar as "tragédias" de sua vida: as dificuldades do pai que tinha vindo da Itália, de sua filha que era esquizofrênica, que seu sogro tinha AVC e que era sua cuidadora, do genro que morreu de acidente.

A fila pode ser um lugar em que as insatisfações sociais somadas a doenças podem vir à tona, revelando um conflito entre serviço de saúde e população usuária, agravando a falta de comunicação, de diálogo. Pude observar, quando o sistema de informação da farmácia estava com problemas, fazendo com que a dispensação se tornasse mais lenta, a fila se mostrando agressiva, exigindo maior rapidez. Em um desses dias, quando cheguei à farmácia, um dos funcionários veio me dizer que um paciente tinha agredido seu colega de trabalho da farmácia e que " $a$ coisa teve feia, a 
direção teve que descer, o povo tava muito nervoso". A este respeito, a fila, ao ser considerada um ponto de encontro, pode ser comparada com os botecos descritos por CHALHOUB (1986), ao demonstrar que nesses locais surgiam conflitos decorrentes das diferenças entre os freqüentadores, sendo reflexo das desigualdades sociais, levando a somar insatisfações através desse encontro de divergências, onde as diferenças são notadas.

Nesse sentido, os problemas sociais são transferidos para os medicamentos, sua falta e a demora em adquiri-lo somam-se com o cotidiano cheio de dificuldades econômicas e sociais. Como a relação farmácia/população está envolta de relações de poder e resistência, uma população que se encontra em condições subalternas nem sempre consegue através do diálogo provocar uma mudança, pois este diálogo já havia se tornado distante pelo silenciamento. O direito nem sempre é exigido através das normas burocráticas, mas através do grito, da voz ativa e imediata, o que faz os serviços de saúde funcionarem como um favor, e não como um direito ( $\mathrm{COHN}$, 2006), e quem está próximo desse grito é quem sofre as conseqüências da busca por mudanças da população, revelando que as reações ao poder são também reações imediatas. É o funcionário da farmácia que se torna o culpado de não ter o medicamento, pela demora para recebê-lo, e não o sistema de saúde. Contudo, as reclamações dos pacientes surtem efeitos, os funcionários da farmácia disseram que eles são considerados "reclamões" frente à diretoria, esta os culpando pela qualidade dos serviços prestados à população. Assim, os funcionários ficam entre dois conflitos: pacientes versus funcionários e direção versus funcionários.

A dispensação de medicamentos não é vista como um encontro entre ciência e população, e para ser efetivado deve ser dialogado, compreendido por seus representantes. Os conflitos entre funcionário e direção podem se estender para outras farmácias públicas, questionando que as outras farmácias não querem pedir medicamentos porque não querem ter trabalho, só querem "bater carimbo" dizendo para os pacientes que não tem medicamentos.

A individualização da culpa revela os conflitos entre população e funcionários da farmácia, facilitando julgamentos como este, de um funcionário: "se 
ele tivesse realmente com problema de tiróide ele não tinha ficado um mês sem pegar a receita”, “ os pacientes são como um rebanho, onde um vai o outro vai atrás".

Em meio a todo o alvoroço de um sistema de saúde que pouco possibilita críticas, ocorre o inesperado, a acusação por parte dos pacientes de erro de dispensação de medicamentos, culpando o pessoal da farmácia. Surge a necessidade de encontrar o culpado antes de avaliar todo o sistema de dispensação. Nessa perspectiva, os comentários aparecem: paciente tomou errado, entregou errado, prescreveu errado. As acusações e defesas tornam-se claras: a farmácia fica de prontidão para a defesa. $\mathrm{O}$ medo de errarem fica ainda mais contundente. $\mathrm{O}$ erro é visto como imediato e não como uma construção. Quando o erro na dispensação voltou-se para a farmácia, surgiu um divisor de águas entre farmacêuticos e auxiliares para questionar o erro.

As explicações na hora da dispensação valorizam a cor dos medicamentos, embalagens. Foi comum as pessoas pegarem os medicamentos na farmácia para outras pessoas, para filhos, netos, maridos, esposas, etc., para pagar a vizinha que tinha emprestado os medicamentos. Apesar de todos os conflitos existentes entre farmácia e população, os funcionários da farmácia revelaram uma função afetiva da farmácia. As informações sobre os medicamentos são repassadas para os usuários em uma situação em que se impõe pressa e agilidade, fazendo elevar o tom de voz dos funcionários, colocando um discurso que acompanha o desespero. Contudo, observei que nas drogarias da cidade a rapidez do atendimento é também é muito valorizada. As informações sobre os medicamentos se restringem a um sentido comercial, a agilidade e rapidez na venda são requeridas por suporem que irá agradar os clientes.

Em um lugar que os medicamentos podem transformar em moeda de troca, ser emprestados pelos vizinhos, sendo que alguns pacientes só vão para pegar na farmácia pública para pagar outras pessoas que emprestaram. Outras pessoas insistem para pegarem medicamentos na farmácia, mas os funcionários dizem que é só com receita, pois é freqüente as pessoas irem sem a receita ou com esta vencida, ocorrendo resistência para irem ao médico, preferindo ir diretamente à farmácia. Os 
dispensadores reclamam que é muito tumultuado, que deveriam separar algumas áreas para ter uma dispensação mais especializada, como os pacientes da saúde mental. Os pacientes do Núcleo de Saúde Mental, que fica a poucos metros do Centro de Saúde, adquirem suas medicações através da farmácia. Desse modo, a dispensação de medicamentos psicoativos como os ansiolíticos e antidepressivos é vista como trabalhosa. Desse modo, a medicina curativa, de que a população foi alvo, torna-se transparente nas filas da farmácia, sendo os medicamentos vistos como uma opção ao imediato, esquecendo de um processo de educação em saúde em que estilos de vida são reavaliados. Assim, pude observar que alguns medicamentos são muito prescritos, como os antidepressivos, os ansiolíticos, antiinflamatórios, protetores gástricos, antibióticos, antitérmicos e analgésicos.

Às vezes, algumas pessoas tomam grande quantidade de medicamentos, as explicações são tumultuadas, o que pode levar a confusão do usuário de medicamentos, principalmente se as informações são repassadas para outras pessoas, como os que pegam os medicamentos para outrem. As informações somente faladas não são suficientes, pois os medicamentos podem
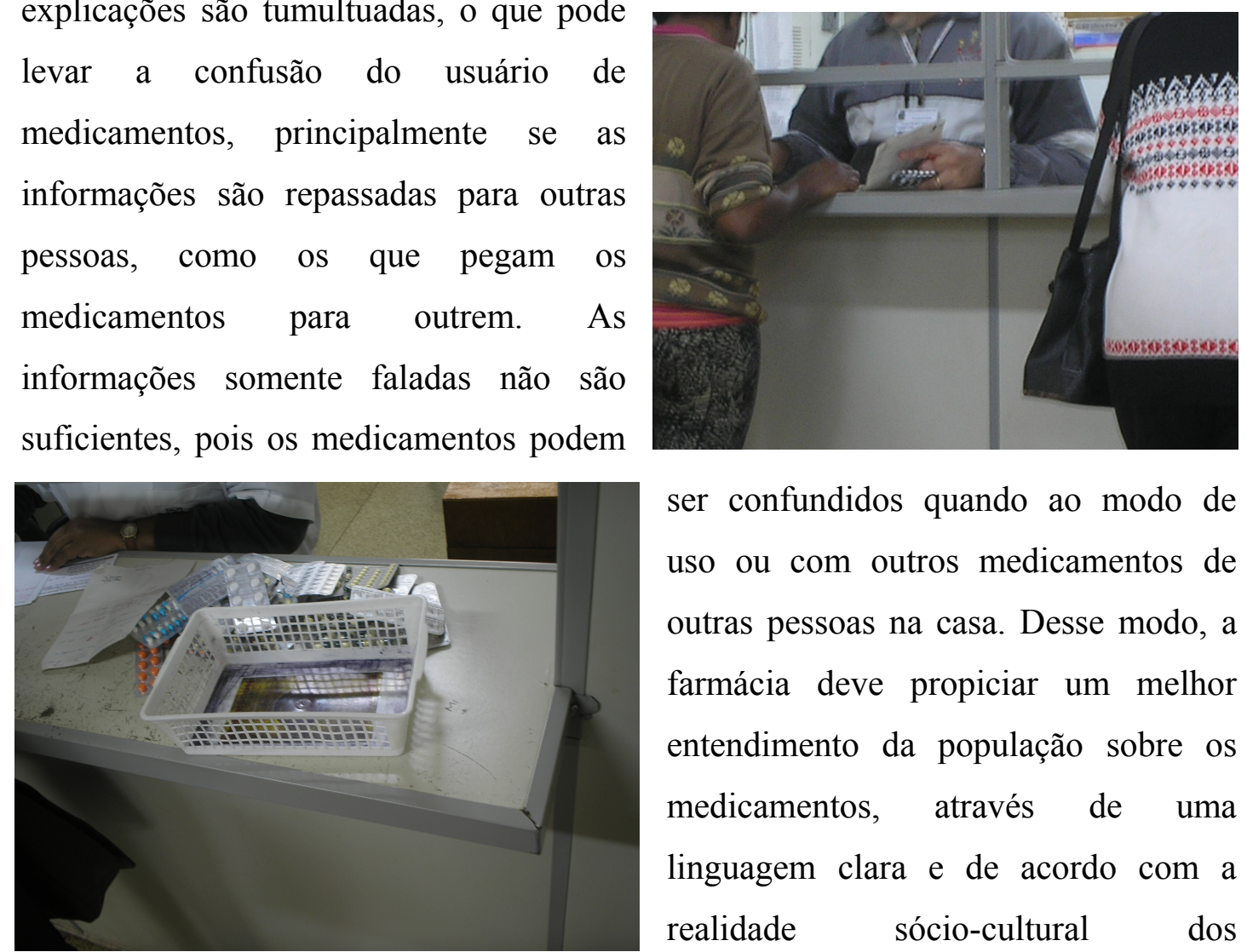

ser confundidos quando ao modo de uso ou com outros medicamentos de outras pessoas na casa. Desse modo, a farmácia deve propiciar um melhor entendimento da população sobre os medicamentos, através de uma linguagem clara e de acordo com a realidade sócio-cultural dos consumidores. Além disso, programas de educação popular em saúde devem ser priorizados, contribuindo pra ocorrer um processo educativo cíclico: entre paciente e 
médico, entre médico e outros profissionais ligados ao medicamento (odontólogos, enfermeiros, auxiliares de farmácia, dispensadores, etc), entre paciente e farmácia e entre paciente e programas que valorizam o contexto sociocultural em que o paciente está inserido, como os trabalhadores da Estratégia de Saúde da Família. Dessa maneira, podem-se evitar erros de prescrição e dispensação, como também orientar pacientes para que os tratamentos sejam realizados da melhor forma possível e que beneficie os pacientes, promovendo reciprocidade entre serviços de saúde e população e autonomia dos pacientes.

Desse modo, ao serem impostos aos pacientes uma racionalização do tempo das consultas e da dispensação de medicamentos, implicando um processo em que não ocorre um diálogo efetivo, a relação medicamento-paciente torna-se mais preponderante, isto é, os pacientes restringem o consumo de medicamento a suas experiências com os medicamentos e com o processo saúde-doença. Assim, como mostrei em minha dissertação de mestrado (MENDONÇA, 2005), as pacientes utilizam os medicamentos a partir de experiências que vão adquirindo com o uso dos medicamentos, através de informações parciais dos serviços de saúde mais a de conhecidos que transmitem os efeitos dos medicamentos no corpo. O cotidiano e a experiência com os medicamentos passam a ordenar o modo de uso, reafirmando o autoritarismo científico e sua impotência frente à resistência dos consumidores. Nesse sentido, as políticas que procuram humanizar os serviços de saúde devem focalizar ações sobre o uso de medicamentos, como a prescrição e dispensação, facilitando um processo educativo e dialógico.

Pude observar a diferença de compreensão sobre os medicamentos, como a relação de anti-hipertensivo com calmantes (ansiolíticos), dizendo que toma este para pressão, e que não agüentar a pressão devido à morte de seu marido era motivo para tomar anti-hipertensivo.

Os usuários dos serviços da farmácia aplicam um sentido de movimento a suas vidas, frases como "se parar o bicho pega", preocupações quanto ao medo de perderem seus empregos, ou, quando autônomos, de terem menores ganhos. $\mathrm{O}$ movimento constante é aclamado como medo da velhice, da lentidão, revelando que 
a disciplina do movimento do corpo possibilita a sua sobrevivência, e quando esse movimento é questionado surge a necessidade de uso de medicamentos. A doença, na fila, é vista como uma falta de movimento, chegando a chamar os funcionários da farmácia de doentes quando são considerados lentos: "olha lá a lentidão, parece que tá doente”, “anda logo que eu tenho o que fazer”.

Apesar do modelo impessoal, pelo estresse provocado na farmácia pela quantidade de pessoas que freqüentam a fila, foi possível observar a persistência de relações de amizade, ocorrendo os desabafos, de suas vidas pessoais, das trocas de receitas de comida. Como disse um funcionário, "eu gosto de trabalhar aqui porque a fila não acaba, tenho sempre o que fazer”. Alguns pacientes são chamados de "pepinos", são vistos como desobedientes, que não seguem as regras determinadas pelo serviço de saúde. Assim, entre o pegar o medicamento na prateleira e o entregar ao paciente surgem alguns comentários sobre os pacientes, sobre o modo como ele lida com os medicamentos, ou comentários sobre suas próprias vidas, ou de outros funcionários, são segundos de desabafos. A pequena espera se transforma às vezes em uma grande conversa que confronta com a rapidez da dispensação. Comentários como este sobre os pacientes: "ele pega 160 comprimidos de diazepam... eu acho que o médico prescreve para ficar livre dele, ele vem quase todo o dia aqui”.

Muitos pacientes vão primeiramente à farmácia em busca dos medicamentos, dizendo que já sabem o que tomar, questionando o porquê de ir ao médico. E os pacientes, quando vão à drogaria supõem que o dinheiro é o suficiente para adquirir os medicamentos, levando, possivelmente, a ver a drogaria restrita a uma relação comercial: "ah, se o meu remédio é barato eu não venho buscar, compro, é muito tempo aqui.",

A grande quantidade de pessoas que adquirem seus medicamentos na farmácia é justificada pelos funcionários como fruto de ações políticas, dizendo que as outras farmácias da prefeitura não estão inseridas em serviços que têm atendimento médico, fazendo com que os pacientes não as prefiram para pegarem a medicação. Um funcionário me disse que a informatização do sistema de dispensação permitiu que ocorresse um policiamento sobre a dispensação, pois antes 
da informatização os pacientes pegavam os medicamentos em várias farmácias da prefeitura. Outro comentário foi sobre alguns pacientes: "tem paciente que gosta da fila, fala do governo, ontem foi uma rizaiada, pacientes gostam de fila, principalmente os aposentados, vêm aqui porque não pagam passagem e tem aqueles que fazem também uma espécie de economia no bairro, sabem que se pegarem aqui os medicamentos, irá sobrar na farmácia de seu bairro”. Os funcionários da farmácia revelam os atritos com o público, transmitindo a culpa pela sobrecarga de trabalho.

O sistema informatizado permite que ocorra controle sobre o número de medicamentos dispensados, fazendo com que o dispensador observe e diga: " $o$ paciente está mentindo, ele disse que os medicamentos acabaram, mas não era para ter acabado". Os conflitos são mostrados e evidencia o distanciamento de um diálogo pautado na confiança, pois o uso incorreto não foi questionado, ocorrendo somente um julgamento sobre o paciente, supondo que este estaria o enganando. As desconfianças são acentuadas quando se trata de medicamentos psicoativos, como os ansiolíticos e antidepressivos.

Os comentários sobre os pacientes continuam, "às vezes vem paciente aqui com dois meses sem pegar os medicamentos e dai quer pegar o atraso, levar tudo”, mostrando que os pacientes têm uma relação da quantidade do tratamento mais do que com a prescrição. Os funcionários relatam que os pacientes começam a fazer o tratamento e depois que melhoram param de tomar os medicamentos, mas de repente chegam à farmácia desesperados pedindo os medicamentos porque não retornaram à consulta: "o paciente transfere a culpa, mas agora é de emergência, me culpam dizendo que eu deixei a mãe dela passar mal por falta de remédio, ora, é ela que deixa e agora vem desesperada querendo até levar o remédio atrasado, sem consultar de novo... toma remédio igual comida, só no dia que está com fome”. De acordo com uma classificação dualista de um funcionário da farmácia, existem dois tipos de pacientes: os que têm medo de ficar sem os medicamentos e levam todos os medicamentos prescritos, tem medo de perder o direito, e os que "jogam limpo" e escolhem os laboratórios dos fabricantes, os medicamentos que vão tomar, levando 
somente estes. É possível notar que em muitas casas os pacientes mostram uma espécie de estoque de medicamentos, ou vão à farmácia quando precisam do medicamento para si ou para emprestar para algum conhecido, como disse um funcionário da farmácia:

"Tem paciente que vive só de emergência, não fala pro médico que não toma o remédio prescrito, dai a pressão não abaixa, ai o médico prescreve um monte de remédios. Ai quando ele chega à farmácia, eu puxo a ficha dele e vejo que ele pega um tanto de remédio. É também aquele paciente que eu acho que tem medo de não pegar o medicamento mesmo não tomando, pois acha que quando ele precisar ele não vai receber."

Os funcionários da farmácia disseram que os médicos podem fazer um falso diagnóstico, pois os pacientes não falam para o médico que não estão tomando os medicamentos. Desse modo, muitos pacientes justificam que não estão tomando os medicamentos por não terem tempo de irem à consulta e pegarem os medicamentos na farmácia. Alguns casos são relatados: “aqui tem aqueles pacientes que ficam dois meses sem pegar a medicação ou quando vem está ruim, a gente vê que foi a igreja que disse que estava curado".

Os conflitos entre população e serviços de saúde são visíveis, por um lado, os pacientes dizem que os funcionários da farmácia não entregaram medicamentos que deviam e por isso vieram antes, por outro, os funcionários dizem que "tem paciente que quer ganhar os medicamentos no grito, começa a gritar na fila, oh, não querem entregar o meu remédio, paciente quer ganhar com conversa, embromar", e dizendo que os pacientes freqüentemente vêm à fila para tumultuar, com medo de perder o direito ao medicamento, contando que entregam medicamentos para três meses e depois de pouco mais de um mês vem para pegar os medicamentos novamente.

A distância social entre serviços de saúde e população é vista através de situações em que a população permite um diálogo, como a descrita por um funcionário: "o marido veio aqui e trouxe umas dez caixinhas de sinvastatina e dizendo que a mulher dele não estava tomando direito e que ele trouxe só um pouco para ela não desconfiar". Disseram também que às vezes os pacientes só querem pegar alguns porque os outros fazem mal, que tem outros medicamentos em casa que substituem o prescrito. 
Desse modo, sugiro que seja melhor analisado como os medicamentos são tomados pelos pacientes, devendo as diferenças entre número de medicamentos dispensados e o consumido pelo pacientes serem problematizadas de forma que o paciente possa dizer o acontecido, devendo essa problematização ter o apoio de profissionais que vivenciam a vida cotidiana dos pacientes, permitindo assim que ocorram economias relativas ao consumo de medicamentos e que os tratamentos sejam realizados para que os pacientes tenham uma melhor qualidade de vida.

As diferenças de uso de medicamento frente à prescrição são refletidas nos conflitos entre funcionários de farmácia e população, impedindo que ocorra um diálogo, levando a conflitos e culpabilidade mútua: "ele veio aqui e me disse se eu não desse o medicamento ele iria passar mal, não teria como porque ele estava sem receita, dai ele insistiu e queria somente para o final de semana".

Em relação ao atendimento individualizado entre farmacêutico e paciente, me foi informado que a sua ocorrência era dificultada pela evasão dos pacientes, que queriam somente "pegar" os medicamentos e irem para suas casas, não queriam conversar sobre os medicamentos. Pode-se assim notar que o uso de medicamento se baseia em normas, como se tivesse uma correspondência perfeita entre medicamento e corpo, em que este não fosse dinâmico e o medicamento previsse a diversidade de efeitos que adquire fora dos laboratórios, na sociedade, fosse perfeito, não sendo necessário ser reavaliado. Acompanhando a variedade de efeitos que os medicamentos podem ter sobre um corpo idiossincrático, temos os diferentes modos de uso de acordo com as concepções dos consumidores, como um dos funcionários disse: "a população briga pelo remédio, fala que não pode ficar sem, mas vem com receita vencida, empresta ou medicam os outros, usa do jeito que quer".

Não usar os medicamentos como foram prescritos revela-se como resistência a submeter aos tratamentos. A prescrição médica possui um poder simbólico, levando o paciente a não falar sobre como seu tratamento está sendo feito, restringindo a relação farmácia-paciente à aquisição dos medicamentos, como relatado na farmácia: "se o paciente usa e melhora ele não quer ir ao médico, pois o que ele quer é o remédio, que é mais importante para ele”. Pode-se notar que existe 
um reducionismo aos medicamentos, o médico passa a funcionar como útil porque prescreve os medicamentos, a farmácia porque os dispensa, levando o paciente a ter uma trajetória dentro dos serviços de saúde em função dos medicamentos, sua saúde ou tratamento se restringe a ele.

“A vida não pode parar”, os movimentos do corpo devem ser constantes, caso o dispensador dedique algum tempo para explicar sobre os medicamentos, a fila reclama, pede para seja desenrolado. Como exemplo, as pessoas da fila começaram a reclamar do dispensador porque ele "parou" para explicar sobre os medicamentos para uma paciente idosa que não conseguia entender o modo de uso. Muitos pacientes não querem pegar a fila, dizendo, como é o caso de uma senhora que estava muito irritada, que não iria para a fila porque já teria ido à outra farmácia e lá não tinha a medicação.

Para um paciente "passar na frente", ele tem que passar por uma espécie de teste, tem que convencer que está muito doente, além de ter o aval da fila, tem que ter o dos funcionários da farmácia. $\mathrm{O}$ aval para passar na frente é posto como momento de conflito e concordância entre funcionários e pacientes: uma senhora perguntou para a farmácia "olha moço, eu posso ter um atendimento especial, eu tô com filho doente, lá, tá fraquinho, tem que ficar escorando ele”, o dispensador disse "só se o pessoal da fila autorizar, a fila é única". Outro exemplo, era de uma mulher que disse que tinha artrose e estava com muita dor, mas não teve a permissão para passar na frente, não convenceu, disse que tinha dor nas pernas e não agüentava ficar na fila. Esta senhora criticou o seu médico por este reduzir seus problemas ao coração, dizendo que agora não era somente o coração, era o estômago, que tinha tomado muito antiinflamatório.

A fila é também definida a partir da classe social, "a fila é para pobre", contudo uma senhora me disse em voz baixa: "oh, eu pego remédio pra mim e para minha filha, ela não mora comigo mais mora num condomínio fechado, maior luxo, mas eu pego remédio pra ela aqui." $\mathrm{Na}$ fila, as relações de poder e resistência são evidenciadas, como a posição de vítima da família e da sociedade, dizendo que estavam doentes e não tinha ninguém por eles, porém, com uma conversa mais 
próxima, muitas pessoas que tinham relatado seus sofrimentos passavam a falar de pessoas que os ajudavam. Nesse sentido, o idoso soma os significados dados à doença aos de velhice, como disse um senhor, que os idosos deveriam ter um atendimento preferencial e que deveria ser implantado um sistema de senha igual ao da "Caixa Econômica Federal". Assim, pode-se notar a relação direta entre serviço de saúde como busca por racionalidade do tempo dos serviços. A doença se transforma em um poder de imposição de vontades, por outro lado muitos idosos ficam sentados em bancos enquanto outras pessoas ficam na fila para eles.

Uma senhora que diz ser umbandista e vidente quis me impor sua vontade para que eu pegasse os medicamentos, dizendo que eu poderia entrar na farmácia porque eu tinha autorização: "eu sou é forte, minha filha morreu, meus irmãos e meus pais, meu santo é forte, se você tivesse buscado o remédio pra mim eu iria te ajudar, você é infeliz com mulher”. Os medicamentos ansiolíticos e antidepressivos são às vezes exaltados na fila, como uma senhora disse sobre os antidepressivos: "olha, eu venho aqui pegar aquele remédio pra me levar às alturas... foi depois que minha filha casou, a vida tá dificil".

Existe falta de interação entre os médicos e a farmácia, sendo prescritos medicamentos que não tem na farmácia, mostrando tanto a ausência de diálogo entre médicos com os pacientes e a farmácia.

Ao procurar conversar com os integrantes da fila, uma senhora fez uma analogia ao substituir a palavra "conversa" por "fila" e disse: "essa fila vai longe". O sentido dado ao corpo saudável como capaz de executar movimentos foi comum na fila. Os medicamentos eram vistos como colaboradores do movimento do corpo: “o carro é movido à gasolina, eu a remédio, estou entrevada das pernas por isso tenho 81 anos, se tivesse boa das pernas teria 18”. O movimento é aqui relacionado à capacidade de trabalho e o cumprimento de seus papéis sociais: "tenho que trabalha se não fico nervosa, eu já tive ruim dos nervos, um olho fechava ou deixava de escutar, trabalhei demais, mas venci, todo mundo tá criado”. A gravidez, ao ser entendida como perda de agilidade física, torna-se um motivo para reclamarem que deveriam ter direito à fila preferencial: a fila possui um conflito de gênero. 
A morte é vista como perda total dos movimentos do corpo, sendo rebatida por uma senhora essa idéia, quando surgiu: "se morrer for descansar eu prefiro viver cansada, é bom ficar cansada, assim a gente consegue dormir melhor". Os medicamentos se tornam um controlador de movimentos, o medicamento faz com que não ocorra a paralisação dos movimentos do corpo, a morte. A doença é vista como conseqüência de um excesso de movimento: "meu coração dói, acho que foi o serviço demais". Movimento, saúde, trabalho e moral se unem, o medicamento é aqui um ordenador dessa união. A quantidade de trabalho está condicionada pela moral, "dar conta do recado social", de criar a família, é um limite moral. A perda da saúde e o "não dar conta" de executar um trabalho podem assim significar perda da moral. O medicamento posiciona o paciente na "corda bamba": muitos possuem medo de dizer que tomam bastantes medicamentos, como exemplo, uma senhora pegou uma sacola de medicamentos e me disse: "tenho que tomar muitos remédios, mas eu não tomo, só pego um pouco porque tem gente que além de não tomar leva pra casa”. A saúde assim nem sempre é vista como direito universal, mas como fruto das relações de poder existentes na sociedade, admitir estar doente pode significar parar de resistir às pressões sociais.

Como os papéis são destacados na fila, os julgamentos também o são, ora avaliando se alguém deve passar na frente, ora questionando o papel de determinadas pessoas, como foi o que um senhor fez sobre uma mãe que gritava com seu filho: "ela faz isso é só pra fazer graça pros outros, é só bater pra valer e depois é só dar uma olhada que a criança treme de medo e te obedece".

A atuação dos serviços de saúde é questionada pela população através da não ocorrência de resultados esperados em relação aos medicamentos: "os remédios não me fizeram bem, tiraram o meu apetite, agora tou fraco, sem apetite... um mal fazendo outro"; "o povo de Ribeirão parece que tá tudo doente, toda vez que venho tá essa fila enorme”.

A fila pode ser vista como lugar estratégico para troca de experiências sobre os medicamentos que tomam, sobre seus efeitos, sendo questionados os modos de consumo prescritos pelos médicos, servindo para fazer comparações entre duas 
receitas, como exemplo, uma senhora aconselha a outra a trocar o antidepressivo amitriptilina pela fluoxetina, dizendo que a amitriptilina lhe dava muito sono. Esta senhora disse que conhecia vários tratamentos porque tinha tido várias doenças e foi citando outros medicamentos. Os questionamentos sobre os tratamentos podem ser destacados com o que uma mulher me disse: "oh, moço, um dia eu tava com fibromialgia, disse o médico dai, eu perguntei pro médico se era problema nos nervos, dai eu num tomei remédio nenhum, eu coloquei a cabeça no travesseiro e vi o que me preocupava, resolvi esquecer. Ora, eu com essa idade (60 anos) vou ficar me entupindo de remédio?" Outro comentário pode ser notado em outra fala: "o meu pai toma marevan, eu só dou a metade e não falo pro médico, pois se dê do jeito deles a gente passa mal, até morre”.

Os questionamentos sobre as prescrições são comuns, a fila é um lugar de comparação. Comentários de que os médicos prescreviam uma quantidade e utilizavam de outra forma era comum, dizendo que também não tinham muito tempo para ficarem indo em retorno e que só iam quando entendiam que precisavam dos medicamentos.

Ao mesmo tempo em que a farmácia é questionada, é elogiada, comparando com outros serviços, que já tinham ido a outras e nenhuma era igual àquela farmácia. Ao redor da farmácia tinham algumas salas de atendimento médico, sendo também elogiados e criticados. Existiu uma projeção para escolha de determinados profissionais, geralmente embasadas no currículo do profissional, como uma mulher que disse que só queria ser atendida pelo médico professor e não pelo médico aluno, “aquele garoto não sabe de nada”. Os outros serviços somam-se ao da farmácia: "aqui precisa melhorar é tudo, você acredita que um dia cheguei cedo aqui e fui sair só às nove da noite”.

Nessas filas, as pessoas carregam suas vidas, suas casas, dizendo além dos tratamentos, comentários sobre as pessoas que a circunvizinham. Os medicamentos antidepressivos e ansiolíticos freqüentemente fazem parte de um assunto: como o fato de uma mulher dizer que não parava de tomar o antidepressivo por medo de engordar; de que fulano está ouvindo vozes, mas o marido agressivo não deixa 
procurar tratamento e de que ninguém denuncia; o falar das angústias, o de "ter uma bola que sobe e desce, arranhando, pressionando a garganta e o peito”; a análise sobre os efeitos dos medicamentos, como dos antidepressivos, que "este de agora (fluoxetina) me dá azia, mas o outro me deixava meio passada (amitriptilina)”.

Os medicamentos são vistos como controladores dos movimentos do corpo, do ritmo, uma senhora disse que sua filha tomava o antidepressivo sertralina, que tinha obsessão, e era por causa desse "mundo acelerado".

Parece-me que a relação com o sofrimento como promotor de futuras recompensas é idealizado pelos grupos populares. As doenças se tornam desajustadoras do tempo, todo o sofrimento social vinculado a exploração de seu corpo como produtor de trabalho, ao não ser recompensado nos momentos em que somam a doença a sua vida, o sentimento de impotência surge, estar doente é sentirse sofredor levando a "verem" sua condição mais próxima, as horas parecem que não passam, alguns minutos eternizam o sofrimento: "com a doença o tempo demora mais a passar, por isso a fila fica ainda mais demorada”, "o que a gente doente pode fazer é só esperar". Uma senhora com um cabelo bem dividido ao meio, um caminho que ligava sua fronte às costas, revelando que o caminho da vida pode significar o fim quando já não conseguia andar: "Oh, eu morri, tive um aneurisma que me matou, depois de nove meses comecei a voltar os movimentos, fiquei toda enroscada, depois de quatro anos eu ando pra todo lado, comecei no quintal, depois ao redor do quarteirão e agora para todo lado".

Em um contexto tumultuado, com telefone tocando, dispensadores e farmacêuticos em um espaço restrito, em que um deve dar passagem para o outro, uma fila que grita, agride, chora, lamenta pela falta de medicamentos. No entanto, a comunicação entre dispensadores e população persiste, são explicações rápidas, principalmente sobre o modo de uso e a dosagem dos medicamentos. Enquanto as tecnologias não chegam aos pacientes em forma de medicamentos, a organização administrativa da farmácia fica sua refém, assim quando o sistema informatizado não funciona, as justificativas não são aceitas: o paciente pede rapidez, toda a sua espera para a consulta faz com que as horas se tornassem mais "lentas", o paciente deixa de 
estar paciente, o estopim chega à farmácia, a sua última etapa no centro de saúde. Os dispensadores ficam irritados, as discussões começam. A farmácia procura soluções para um atendimento mais rápido, os usuários deixam suas respostas, como se vê na foto seguinte.

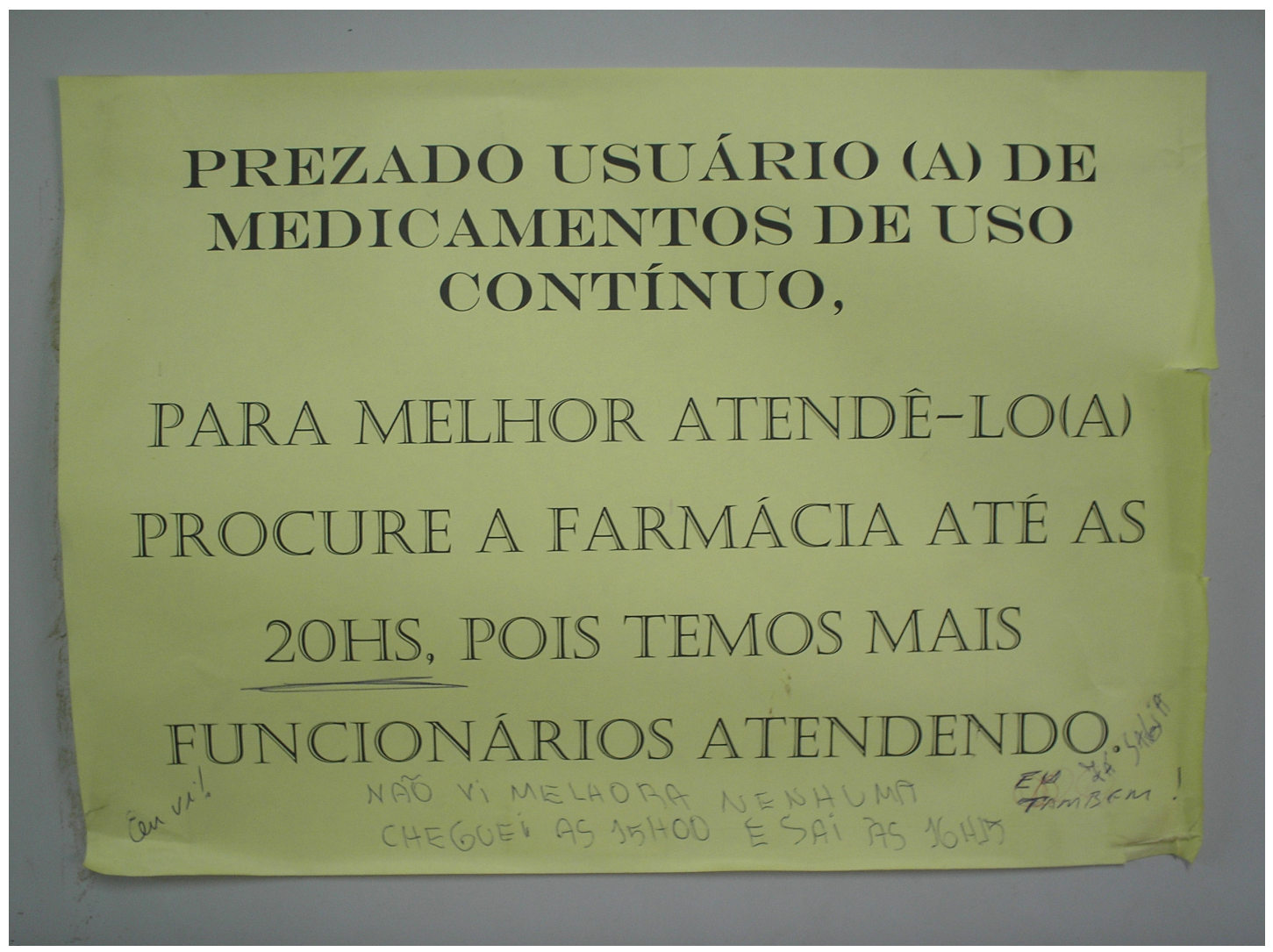

\subsubsection{Do público ao privado}

Os conflitos entre ciência e população estão presentes também na parte interna da farmácia, entre os funcionários da farmácia: entre auxiliares de farmácia e farmacêuticos. Ocorre uma competição pelo saber, os auxiliares, não sendo farmacêuticos, dizem que experiência conta muito e que na escola não se aprende 
tudo, questionam a função dos farmacêuticos quando não querem ficar frente a frente com os pacientes, dispensar os medicamentos. Os farmacêuticos são avaliados pelos dispensadores. O farmacêutico que fica dispensando é visto como um ajudante, dizem que o que não fica não ajuda, e às vezes atrapalha. Alguns auxiliares, por já terem trabalhado anteriormente em drogarias, fazem comparação com a farmácia, de que na drogaria a produção é valorizada, paga-se um preço pelo seu trabalho, e que ali a fila só reclama, não existe recompensa pelo esforço. Porém, dizem que os empregos nas drogarias não são tão garantidos porque se as vendas caem, correm o risco de perderem o emprego.

Observei comparações e diferenças entre as drogarias da cidade de Ribeirão Preto-SP e a farmácia pública pesquisada. Nas drogarias, a relação comercial da assistência farmacêutica sobrepõe as outras relações à medida que a venda de medicamentos é a garantia do estabelecimento de saúde, e os funcionários da drogaria geralmente possuem uma cota determinada para venda, sendo distribuídas entre os diferentes medicamentos e divididos entre as categorias de genéricos, similares e de referência. Essa divisão acompanha a lucratividade dos laboratórios farmacêuticos, o que leva o processo de troca de um medicamento por outro no ato da venda, pois mesmo sendo vendido a um menor preço, a margem de lucro pode ser maior. Nessa perspectiva, como geralmente os similares e genéricos possuem maiores margens de lucro, a cota de venda sobre esses produtos são mais rigorosas, recebendo prêmios seus melhores vendedores. O bom farmacêutico transforma-se em bom vendedor, aproximando-se de um balconista ou auxiliar.

Os farmacêuticos que ficam no balcão, como dizem os auxiliares e balconistas, que participam das vendas, são os melhores. Aqueles farmacêuticos que ficam cuidando da parte administrativa da farmácia são questionados, criticados. A dispensação de medicamentos não é vista como um processo educativo sobre os medicamentos e é restrita a um sentido mecânico de pegar os medicamentos nas prateleiras e a sua venda.

Os balconistas considerados mais experientes dizem que os funcionários de hoje são apenas catadores de medicamentos, não são vendedores, não sabem indicar 
os medicamentos, principalmente os que são mais lucrativos. Os auxiliares e balconistas dividiram o profissional farmacêutico: os que ficam longe e os que ficam próximos aos pacientes, estes se aproximam deles e aqueles são chamados de administradores.

Os auxiliares e os balconistas das drogarias parecem aproximar-se quanto aos atritos com os farmacêuticos, principalmente relativo à competição entre saberes. Os comentários entre experiência e diploma universitário são comuns: "eu não troco os meus 15 anos de farmácia pelo diploma dele”. A competição para venda pode ser notada nas pressões do mercado de trabalho. Em Ribeirão Preto, foi possível observar que alunos do curso de farmácia já trabalhavam nas drogarias. Os farmacêuticos às vezes admitem não terem experiência, valorizando a capacidade de venda do balconista, tendo este um salário equiparado ao do farmacêutico.

As intrigas estão relacionadas aos estudos, o diploma, ao provocar silenciamento e hierarquia, provoca conflitos, rejeição, resistência, como disse um auxiliar de farmácia: "aqui não pode tomar decisão, a decisão são dos farmacêuticos". Enquanto nas drogarias o farmacêutico que é um bom vendedor pode ser temido por conseguir ter maiores vendas, não deixando o balconista vender, na farmácia pública o sentido de ajudante do farmacêutico é requerido. Os auxiliares reclamam que alguns farmacêuticos dizem que se precisarem é para chamar. Assim, a assistência farmacêutica fica restrita a alguns casos requeridos, não sendo um efetivo vínculo com a população, pois é constantemente no momento da dispensação que as informações devem ser sempre prestadas, desenvolvendo relação de confiança e interação sociocultural, analisando a prescrição médica, observando as interações medicamentosas, dosagens, os modos de uso, etc. Os farmacêuticos são freqüentemente vistos como símbolos científicos facilitadores do consumo, o conhecimento científico é direcionado para os maiores ganhos.

Nas drogarias e farmácias nota-se a formação de uma hierarquia. Na farmácia do centro de saúde se resume aos farmacêuticos e auxiliares, enquanto nas drogarias a hierarquia pode ganhar outras direções ao existirem muitos funcionários. Além disso, as drogarias do centro, geralmente pertencentes a uma rede de drogarias, 
podem ganhar novas configurações, que vão desde o vestuário até a disposição dos funcionários. O farmacêutico pode às vezes ser diferenciado por seu vestuário, pela roupa personalizada.

Os balconistas podem ser divididos em atendente um, dois, etc. Além desses, existe a presença de uma nova especialidade, a perfumista, podendo ser uma pessoa que trabalha no caixa que passa também a ser responsável pela venda dos produtos da perfumaria. E existe o encarregado, um gerente da loja (como é chamada a drogaria), que simula o papel de dono, podendo variar desde um balconista, perfumista ao próprio farmacêutico. O encarregado tem uma posição que impõe ordens à drogaria de uma rede, promovendo atritos, sendo intensificados de acordo com a disposição dos cargos e as relações de poder, como exemplo um balconista pode se tornar um encarregado e ao impor ordens ao farmacêutico este pode se sentir incomodado com a hierarquia. Na farmácia pública, é destacado que a pessoa fica para sempre naquela função para que foi contratado. Na drogaria, pode ocorrer uma disposição relativa ao sexo. As mulheres geralmente trabalham no caixa e na seção de perfumaria, enquanto os homens cuidam dos negócios, das vendas. Porém, nota-se que esta disposição está mudando, existindo hoje mulheres balconistas. Desse modo, muitas mulheres preferem que somente outras mulheres apliquem injeções.

A relação entre público e privado está inserida no consumo de medicamentos. Um dos bairros que pesquisei possuía uma drogaria, que por ficar longe das redes de drogarias e próxima a uma população com menor poder aquisitivo, orientava suas vendas para os medicamentos similares. Em minhas visitas a esta drogaria, pude observar que muitas pessoas iam comprar seus medicamentos dizendo que na farmácia pública estava em falta. Como na farmácia pública a dispensação se baseia no menor custo, nos medicamentos similares e genéricos, a drogaria possuía uma concentração na venda desses medicamentos. A farmácia estava direcionando a venda para esses produtos. Nesse sentido, as drogarias localizadas nos bairros populares são postas como drogarias que vendem bastantes medicamentos similares. O consumo de medicamentos revela desigualdades sociais. 
As drogarias de bairro ou "farmácia de bairro", geralmente mais antigas na cidade, cujo dono tem experiência em vendas e indicações de medicamentos, estão perdendo espaço para as redes de drogaria, também devido à concorrência de preços. Contudo, seus donos são vistos como experientes vendedores, sabedores dos medicamentos que dão maior margem de lucro, diferenciando dos novos balconistas, muitos chamados para trabalharem em outras drogarias consideradas maiores, como as de rede. Assim, no meu dia-a-dia nos bairros pude ver entregadores de medicamentos em suas motocicletas, sendo adquiridos pelos moradores possivelmente via telefone, mostrando que a venda de medicamentos caminha para uma maior impessoalidade.

No entanto, quando a venda ocorre no estabelecimento, apresenta um cenário de concorrência entre os vendedores. Como observei, os balconistas jovens são criticados pelos mais velhos, estes dizem que aqueles não sabem vender, não sabem indicar, que são apenas catadores de medicamentos nas prateleiras das drogarias. Em uma das drogarias um balconista me disse que havia aprendido a profissão de balconista limpando o chão e as prateleiras da drogaria, e que somente depois de alguns anos que conseguiu passar para o balcão, mas naquele momento já não mais ocorria isto.

Notei que muitos balconistas mais jovens tiveram um passado voltado para outros tipos de trabalho centrados em vendas, como o ser vendedor em loja de eletrodoméstico, shopping, supermercado. Os balconistas mais velhos são tidos como especialistas em vendas, uma espécie de professor que ensina os mais jovens a serem vendedores de medicamentos, incluindo também os farmacêuticos. Alguns desses balconistas dizem que estão treinando os farmacêuticos para vender. A experiência com vendas de medicamentos questiona o "diploma" do farmacêutico à medida que os medicamentos se resumem ao comércio. Os novos balconistas são analisados a partir de suas práticas em vendas, tornando-se, com a aquisição de experiência, um especialista em vendas de medicamentos, importando em primeiro plano a técnica de venda, como estar sempre sorrindo e passar segurança, saber indicar os medicamentos com maiores margens de lucros sem se prejudicar, isto é, vender o 
máximo que se pode sem provocar danos à saúde do consumidor de medicamentos, principalmente os sintomas agudos.

Os medicamentos de venda livre, que não são tarjados, são bastante indicados por serem considerados erroneamente menos nocivos. Essa lógica de venda é também aplicada com os medicamentos com venda sob prescrição médica, contribuindo para a automedicação. Acredito que esta relação com o comércio da drogaria contribua nas atitudes da população de requerer seus medicamentos sem receitas médicas na farmácia do centro de saúde. Tanto no setor privado como no público pude perceber pacientes irritados por não terem conseguido medicamentos ansiolíticos e antidepressivos, que são dispensados com a retenção de receitas.

A farmácia pública não se distância da privada em termos de exigência do público para adquirir os medicamentos, ambos exigem rapidez. $\mathrm{O}$ farmacêutico perde sua função de educador que produz um diálogo com o usuário de medicamentos para a de rapidez e precisão na entrega dos medicamentos. As pessoas se mecanizam, se coisificam, já não são mais os produtos que estão em uma esteira, são as pessoas que passam, devendo os dispensadores abastecê-las de medicamentos, e caso se perca o ritmo, ocorrem pressões por parte das pessoas que estão à espera. É com a intenção de serem abastecidos de medicamentos que pude observar que a venda ocorria para alguns clientes na drogaria na forma de kit, sendo distribuídos como um conjunto de medicamentos para viagem (exemplo, antiácidos, antiinflamatórios, antitérmicos, antibióticos, relaxantes musculares, antialérgicos, etc), kit para festa (antiácidos, remédios para dor de cabeça, antitérmicos, etc), kits para situações de estresse (calmantes, antidepressivos, estimulantes, vitaminas, etc). Aqui o uso preventivo, o medo da doença ou mal-estar são gestados pela compra de medicamentos e a formação de um estoque em suas casas. Do mesmo modo, como já mostrei, os pacientes formam estoque, às vezes pegando medicamentos em mais de um serviço de saúde, como o de duas cidades.

A correspondência a um modelo de rapidez ocorre também quando os pacientes ou, como são chamados nas drogarias, clientes, vão à farmácia ou drogaria e ficam questionando ou pedindo informações sobre os medicamentos. São 
considerados inconvenientes, impedidores do movimento dos ganhos nas drogarias, do movimento da fila, da engrenagem do sistema de dispensação. Contudo, como a assistência farmacêutica se especializou em algumas doenças, fornecendo atendimentos diferenciados, como os pacientes de doenças crônicas e idosos, a drogaria também se especializa nos clientes chamados de especiais, aqueles que todo mês compram seus tratamentos crônicos. Pode-se afirmar que através de táticas de vendas se observam nas drogarias cartazes com descontos especiais para idosos, em determinados medicamentos, etc. Nas drogarias pode-se acrescentar a presença de um cartão de fidelidade, permitindo rastrear o que o cliente está consumido, fornecendo descontos e orientando vendas.

É importante destacar o processo de medicalização através das drogarias e farmácias, sendo contribuído pelo tipo de formação que os profissionais de saúde possuem, geralmente valorizando o mercado de trabalho e ganhos individuais mais do que a relação humana entre profissionais de saúde e sociedade. A descoberta dos diferentes modos de usos dos medicamentos faz parte de um processo interativo entre profissional e população, envolvendo confiança mútua e diálogo. Na drogaria, pode-se observar que mulheres utilizavam anticoncepcionais para cólica, como disse uma mulher que sua amiga a tinha indicado o anticoncepcional certo para a cólica; um homem que me disse que utilizava o anti-hipertensivo para controlar a sua pressão, que ela deveria estar no nível certo, por isso quando a pressão estivesse baixa, sentindo sonolência, ele também tomava o medicamento; pessoas que só utilizam a metade dos comprimidos prescritos; pessoas que tomam os medicamentos em menor tempo supondo que se curariam mais rápido. A prescrição médica deve ser uma orientação para promover educação, não devendo ser vista como um bilhete de ordem pelo qual os pacientes são avaliados como bons ou ruins, que aderem ou não aos tratamentos, corretos ou errados, pacientes considerados rebeldes, resistentes ao tratamento.

A farmácia pública mostrou-se fragmentada com o restante dos serviços de saúde, os pacientes pareciam não fazer parte de um diálogo envolvendo os diferentes profissionais de saúde (médicos, enfermeiros, odontólogos, farmacêuticos, etc). Os 
pacientes recebem uma prescrição que nem sempre é a desejada, mas imposta como uma ordem e, em seguida, a farmácia reafirma esta ordem, enfatizando o modo de uso dos medicamentos. O paciente resiste, pressiona, é o dualismo entre paciente e serviços de saúde estruturando uma relação que deveria ser pautada no diálogo e na troca de conhecimentos e não na procura de um culpado, ora sendo o governo, ora os dispensadores, ora os usuários dos serviços, ora os médicos, etc.

As disputas entre farmacêuticos e balconistas também foram observadas por BARETA (2007) no município de Campina Grande do Sul-PR, notando que os balconistas diziam que os farmacêuticos possuíam um diploma, um conhecimento científico, incompatível com seus anos de experiência e com a realidade da dispensação, e que os farmacêuticos estavam mais relacionados a questões burocráticas, como preencher os requisitos relacionados a fiscalização do Conselho de Farmácia e da Vigilância Sanitária, enquanto os farmacêuticos diziam que deviam estar presentes tanto para cumprir as normas legais que exigem sua presença como para atender as eventualidades de alguém requerer seu atendimento. As disputas proporcionam divisões a partir da venda, por isso um diz não interferir na venda do outro. Assim, os farmacêuticos também reconhecem o valor da prática dos balconistas e auxiliares: um auxiliar da farmácia me disse que alguns farmacêuticos não atendem porque se dizem não terem prática, que aquilo era para os auxiliares.

A divisão entre prática e teoria persiste fora da faculdade, sendo um das justificativas na separação dos trabalhos. Desse modo, a venda de medicamentos psicoativos, como os ansiolíticos e antidepressivos, por ser entendida como uma venda burocrática, que possui uma legislação específica que regula sua dispensação, geralmente se torna uma obrigação do farmacêutico, tendo este que passar a controlar o estoque desta medicação. Estes medicamentos ficam retidos em armário de psicotrópicos, de cuja chave o farmacêutico é o detentor. Observei que muitos farmacêuticos restringem suas atividades a este armário, que é historicamente muito enfatizado pela Vigilância Sanitária e pelo Conselho de Farmácia, levando o farmacêutico a se reduzir a esta preocupação, e os medicamentos psicoativos ganham 
uma conotação de responsabilidade do farmacêutico, esquecendo de outros medicamentos.

Nas drogarias, os farmacêuticos são freqüentemente vistos como dispendiosos pelos balconistas, pois não são considerados bons vendedores. Os farmacêuticos às vezes são considerados um entrave para as vendas, pois podem impedir o consumo desordenado de medicamentos, a automedicação, as indicações dos balconistas. É nesse jogo de disputa que o farmacêutico resolve se tornar um vendedor, competir, ganhando elogios ao utilizar seus conhecimentos em prol da venda de medicamentos. O farmacêutico passa a ser requerido pelo balconista para afirmar suas "verdades" quando o cliente duvida, o cliente deve confiar nos medicamentos e para isso: "vou chamar o farmacêutico". O diploma se mercantiliza.

No passado, a ausência de fiscalização sobre as drogarias e farmácias propiciou que o farmacêutico ficasse ausente desses estabelecimentos, facilitando aos balconistas a venda de medicamentos não centrada em bases científicas, mas no empirismo. Muitos donos de farmácias e drogarias às vezes nem queriam um farmacêutico presente, "só quero para assinar"; a responsabilidade técnica do farmacêutico se reduzira a sua assinatura para o funcionamento "legal" desses estabelecimentos enquanto a responsabilidade para com a população era substituída pelo sentido comercial dos medicamentos. Contudo, hoje a maior fiscalização sobre as drogarias e farmácias não é suficiente para impedir a restrição do consumo dos medicamentos ao comércio; as pressões do mercado de trabalho induzem os farmacêuticos e balconistas a se preocuparem cada vez mais com o número de vendas de medicamentos. De acordo com BARETA (2007), o profissional farmacêutico passa por um processo de redefinição de seus papéis, devendo voltar sua prática a partir dos pacientes, devendo a venda dos medicamentos ser problematizada: "Ao falar-se da farmácia, o farmacêutico abre espaço para a atuação de agentes leigos, permitindo, ao longo da história que se construiu a partir da metade do século XX, a transferência do saber farmacêutico para o agente leigo, em sua relação com o paciente, legitimando esta relação, já que o saber, como 
instrumento simbólico de poder, é instrumento de integração social" (BARETA, 2007, p. 47).

O farmacêutico deve buscar interagir não só como a população em si, mas com os auxiliares e balconistas, contribuindo para a realização de um processo educativo. Como se pode observar, o consumo de medicamentos envolve uma grande diversidade de profissionais de saúde, indo desde pessoas com curso superior até os considerados práticos, que aprendem a comercializar os medicamentos com suas experiências que vão adquirindo nas farmácias e drogarias. Desse modo, sugiro que os balconistas e auxiliares sejam melhor qualificados, se transformem em uma profissão definida a partir de conhecimentos científicos.

O consumo de medicamentos envolve um percurso histórico e social que está marcado pela diferença no modo de sua produção, correspondendo ao papel do farmacêutico frente à sociedade. Como BARETA (2007) diz, o fato do farmacêutico antes preparar os medicamentos, ele recebia maior prestígio do que hoje, pois era ele quem demonstrava o domínio do conhecimento sobre os medicamentos em uma produção personalizada em um número restrito de medicamentos, contudo, a partir da metade do século XX, ocorre a industrialização dos medicamentos e a projeção de uma produção impessoal, refletindo na dispensação dos medicamentos.

O consumo de medicamentos está envolvido por aspectos simbólicos, além dos científicos, com as diferentes concepções sobre os medicamentos. Assim, pude observar que muitos pacientes não acreditam na impessoalidade do atendimento, preferindo as pessoas que eram consideradas socialmente mais próximas, não querendo o conhecimento científico do farmacêutico em lugar da simpatia existente com o auxiliar ou balconista de farmácia e drogarias: "eu quero falar com o balconista”. Um atendimento na farmácia ou drogaria envolve um encontro sociocultural, os profissionais relacionados ao uso de medicamentos devem envolver um processo dialógico em que um aprenda com o outro.

As preocupações relacionadas à estrutura da farmácia do Centro de Saúde Escola (CSE) se reduziram ao tempo e não à qualidade das informações e da interação com a população, levando ao distanciamento do farmacêutico e dos 
auxiliares de farmácia de um processo educativo e de humanização em saúde relacionado à promoção de saúde. A mudança do modelo informatizado revelou que a rapidez da dispensação é considerada preponderante para o modelo curativo, pois a rapidez da dispensação não somou a informação, mas a rapidez com que a fila deve seguir. O sistema de atenção farmacêutica se reduz a doenças especificas e não ao medicamento em sua relação com a sociedade. A assistência farmacêutica muitas vezes reduz o medicamento à doença, esquecendo que os medicamentos são interpretados pelos consumidores em diferentes contextos não necessariamente envolvendo a doença, reelaborando conhecimentos de acordo com o contexto sociocultural e promovendo um consumo distanciado dos preceitos científicos. Além disso, a assistência farmacêutica deve ser incluída em uma relação interdisciplinar envolvendo os diferentes profissionais, como médicos, balconistas e auxiliares de farmácia, enfermeiros, auxiliares e técnicos de enfermagem, etc, refletindo sobre as necessidades e o uso de medicamentos.

\subsection{CONSUMO DE MEDICAMENTOS ANTIDEPRESSIVOS E ANSIOLÍTICOS: GESTORES DE CONFLITOS}

\subsubsection{Iniciando em um campo de encruzilhadas}

O trabalho de campo me pareceu como a possibilidade de interpretar e compreender tanto o outro como minha pessoa através do encontro de trajetórias, colaborando para a reflexão sobre minha pessoa à medida que penso sobre o outro. Nesse sentido, é também um trabalho de autocrítica que revela muitos medos existentes entre os profissionais de saúde, medo do desconhecido, mas que é 
ilusoriamente imaginado como íntimo, vestido, detalhado: são os preconceitos sobre o outro. O medo que se dissimula de defesa para ofender, para dizer ao outro que ele significa perigo, dificultando o diálogo. Procuro assim privilegiar o diálogo, compreendido como a principal função do pesquisador ao interagir com o outro, produzindo reflexões, aproximação com a realidade. Mencionar o outro sem uma interação é cair em uma transcrição distorcida, autoritária sob a ótica do pesquisador, somada a uma infinidade de referências bibliográficas descontextualizadas com a realidade local vista. Contudo, tento pegar as migalhas de uma pequena inserção para construir um texto, são em pequenas palavras como um "oi", "um bom dia", que fui cerzindo o diálogo, cada ponto, cada aparência interagindo com realidades diferentes, ora mais próximas, ora mais distantes, ora harmônicas, ora conflituosas: com o tempo interagi vivências, apesar de vivências curtas, menos de um ano e meio. Se fosse uma criança, estaria ainda engatinhando.

O diálogo produzido e minhas observações não estão ausentes de recortes, como o relacionado à interação através de uma maior vivência com o outro que favorece o diálogo à medida que aprofunda compreensões e interpretações (GEERTZ, 1989), ou de ampliação do estudo sobre os esquecimentos, pelo espaço academicamente circunscrito (CERTEAU, 2005). Assim, analisar a relação do consumo de medicamentos com a sociedade é problematizar os diferentes contextos socioculturais através da proximidade com os usuários, verificando detalhes no modo de usar.

Não escolhi caminhar pela suposta e ingênua homogeneidade em que grupos sociais vivem, observei a diversidade. O trabalho fez um trajeto de encontro entre a minha pessoa e a dos pesquisados, sendo visto socialmente e individualmente através das entrevistas. Quando passei inicialmente pelas ruas de um dos bairros, somente andando a passos lentos, os conflitos não eram observáveis, a população mostrava-se homogênea, sem intrigas, ódios, desconfortos. No entanto, com o passar dos dias, ruas, as casas, os bares, já não possuíam o mesmo sentido impessoal de antes, os pontos indefinidos começados por "um(a)" se transformaram em definidos iniciados por “a(o)". Com a convivência, os bairros ficaram pessoais e cada vez mais se 
caracterizando por encontros e desencontros ora casuais ora determinados. Ao mesmo tempo em que minha relação com os bairros se estruturou entre pontos previamente determinados através da lista de pessoas que entrevistei em suas casas, para a realização de entrevistas e pelos encontros não programados surgidos no meu dia-a-dia, observei que os moradores dos bairros também possuíam seus caminhos imprevistos e programados, como o cumprimento das visitas aos parentes, a freqüência à igreja, ao boteco, ao serviço de saúde, à farmácia.

Assim, a pesquisa em si procurou fazer estes dois caminhos se encontrarem, o do pesquisador e do pesquisado. Pode-se dizer que saber compreender estes diferentes caminhos é um dos primeiros passos na entrada do pesquisador em seu campo, possibilitando visualizar alguns encontros e desencontros, observar o porquê de um grupo de homens irem ao mesmo bar todos os dias, de pessoas não freqüentarem determinada área do bairro, do porquê de algumas pessoas irem somente a determinadas casas. Essa interação de caminhos favoreceu localizar os primeiros conflitos. Desse modo, palavras inicialmente não ditas, com o tempo, com a interação e a confiança, passaram a ser faladas, as necessidades que pareciam coletivas passaram a ser singularizadas, o consumo dos medicamentos psicoativos (restrinjo aqui aos ansiolíticos e antidepressivos) já não se restringia à doença, mas incluía o cotidiano de cada trajetória, cada curso de vida. Uma aparência enganosamente tão nítida, possuindo até aval científico registrado nos prontuários médicos, perdia-se a cada nova conversa, a cada nova realidade revelada.

O encontro de caminhos me levou a problematizar diferenças e semelhanças entre os pesquisados, marcadas pelo confronto entre um "eu" e um "nós". O que era considerado local, semelhante, estava inserido em uma complexa dinâmica, ser um “eu" e ser um "nós" simultaneamente, todavia um "eu" e um "nós" que podia ser plural e singular. Um "eu" inserido em um "nós" que a cada novo encontro se mostravam diferentes. Assim, localizava-me entre um olhar não tão distante que não conseguia ver diferenças e não tão muito próximo que ficava ofuscado, revelando relações de poder e de resistência, formação de um caminho tortuoso e conflituoso. Nesse caminho pude deparar com minha condição de deslocado, simplório a uma 
realidade geralmente vista como homogênea através das configurações midiáticas, equívocos sobre o Outro desconhecido para mim. As evidências já nem comentadas pela população se mostraram a mim como um segredo, revelações descobertas à medida que interagia com outros universos, outros caminhos. E, no mesmo sentido, muitas vezes me vi como um mistério a ser desvendado, notei que era tão pesquisado quanto pesquisava, e questionamentos, fofocas e intrigas surgiram nesse descobrir e ser descoberto, fazendo-me refletir sobre minha posição, o que representava para a população pesquisada e os efeitos desta representação.

Desse modo, as minhas idas e vindas do Estado de Goiás para a cidade de Ribeirão Preto ganharam outras conotações, antes uma simples viagem cansativa, depois um encontro de frustrações, alegrias e saudades, como uma pessoa me disse no ônibus: "não agüento mais de saudade da comida de minha mulher, fiquei aqui três meses trabalhando, não agüentei”. Eram pessoas semelhantes as que eu encontrei no campo da pesquisa, pessoas que vieram de outros Estados como Minas Gerais, Goiás, Rio Grande do Norte, Ceará, Bahia, em condições diferentes à minha, mas fazendo um mesmo percurso, pessoas que se separam dos chamados "da terra", os que nasceram em Ribeirão Preto. Eram pessoas que iam para estudar, trabalhar, ora com condições econômicas que permitiam possuírem casas luxuosas, ora com dificuldades socioeconômicas que as levaram a residir em pequenos barracos feitos de papelão, pedaços de madeira, arame e parcialmente telhado. Estes eram geralmente abertos ao vento, aos olhares, mas barrados pelas imposições dos donos, aqueles cercados com muros altos, com cercas elétricas, com o silêncio que percorria a rua e pelo apito dos vigilantes que passavam com suas motos.

Busquei analisar o consumo de medicamentos antidepressivos e ansiolíticos, observando que o modo de uso não está só ligado às superficialidades generalizadas dos diferentes contextos socioculturais, mas à proximidade com os usuários, exigindo que adentrasse os diferentes contextos para visualizar singularidades, dialogando com o outro. Era nesse diálogo que transparecia minha trajetória de vida ao se fundir com outras, levando-me a escolher caminhos a serem percorridos, fabricando um encontro inusitado entre pesquisador e pesquisado. Nesse sentido, o 
local geográfico de onde vim, minha formação, meus trabalhos, minha origem rural ou urbana e a perspectiva teórica que utilizei para desenvolver a pesquisa, entre outros, são importantes. O encontro entre trajetórias de vida pode assim envolver amizades, conflitos, recusa, aversão, etc., pode haver julgamentos.

Nessa perspectiva, o trabalho de observação participante acompanha o curso da vida e não se esgota, não se limita a um tempo, mas ao tempo de vida. Caso, hoje voltasse lá, encontraria um "outro" universo para ser pesquisado, "outros" encontros e desencontros. A observação participante participa da dinâmica social e cultural. Admitir a condição de infinitude da pesquisa é perceber que a vida resiste aos enquadramentos, às formatações, às divisas de territórios, campos, em que o pesquisador defende como dele, provocando o questionar poderes. $\mathrm{O}$ trabalho de campo necessita de objetividade para o estudo, mas sendo parte da vida do pesquisador, é um recorte que deve ser analisado de forma interdisciplinar, em ligação de saberes, interagindo o percurso sócio-histórico da humanidade através da comunicação entre indivíduo, espécie e sociedade, assim como do passado, presente e futuro, reconhecendo incertezas, contradições e a dinâmica do conhecimento (MORIN, 2005). Assim, a cada passo que dou, construo uma estrada, que é minha, porém compartilhada, a cada movimento esta estrada forma outra. Seria uma ingenuidade pensar que se voltar ao campo de pesquisa hoje, encontraria o mesmo de antes, a própria pessoa do pesquisador já não é a mesma, formará um novo diálogo, um novo conflito, uma nova fusão. PEIRANO (1995, p. 45) esclarece sobre estas questões levantadas acima, sobre a pesquisa etnográfica e a construção da experiência do pesquisador ao interagir com o pesquisado: "a pesquisa depende, entre ouras coisas, da biografia do pesquisador, das opções teóricas da disciplina em determinado momento, do contexto histórico mais amplo e, não menos, das imprevisíveis situações que se configuram no dia-a-dia local da pesquisa". 
Desse modo, começo a descrever pela minha inserção no campo da pesquisa, demonstrando como um único ponto visual pode interferir em todo o percurso criado pela pesquisa, ponto que se soma ao passado do pesquisador. Quando mudei para as proximidades do Centro de Saúde Escola e dos bairros que iria pesquisar, pude através de minha casa ter um campo visual que revelaria diversidade que iria se repetir, fazendo-me lembrar das similaridades já ocorridas em minha vida, contribuindo para refletir sobre o ambiente pesquisado. Encontrei um confronto demonstrador de diferentes conflitos: rural versus urbano, masculino versus feminino, pobreza versus riqueza, centro versus periferia.

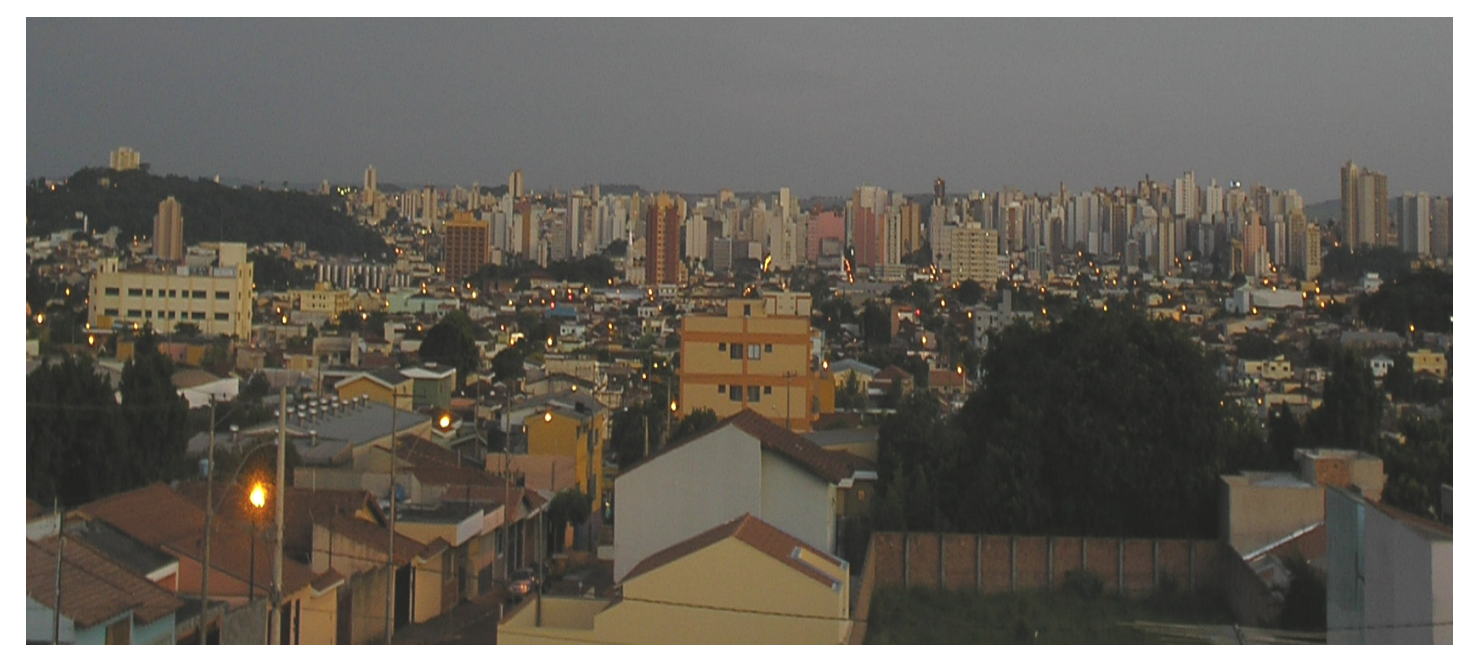

Ao lado de minha casa, tinha uma casa com cerca elétrica sobre o muro, as crianças brincando, as reuniões familiares aos finais de semana. Do outro lado, uma espécie de "pequena fazenda", como mostra a foto seguinte, dois lotes cheios de plantações frutíferas divididos pela rua asfaltada, com a presença de um senhor nos finais de tarde que cuidava das plantas, não deixando perder o laço entre o urbano e o rural. 


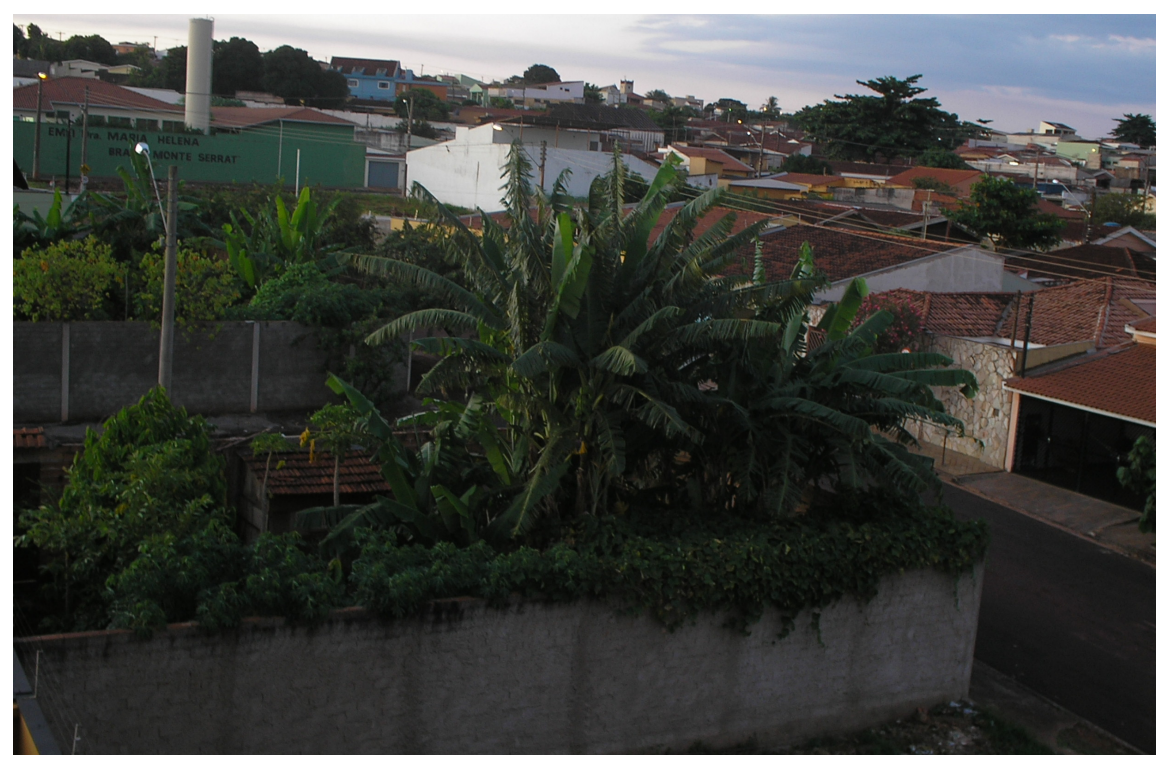

Tive também a presença de outro vizinho, um gentil informante. Era uma pessoa solitária, vivendo com o seu trabalho de catador de papel, uma pessoa que antes já tinha feito um percurso inverso ao meu, tratando-me por "goiano", conversando sobre suas “andanças” por Goiás, as cidades, os cabarés que freqüentou, os fazendeiros com quem trabalhou, do dinheiro que tinha ganhado e do pesar de ter gastado tudo, do se culpar: "é cabeça ruim, goiano, por isso tô assim".

É quando acordo, saio pela porta da frente e encontro meu vizinho, rindo e falando "eh goiano", dizendo às vezes que está com ressaca da bebida no dia anterior, sempre me chamando para "tomar uma, goiano", uma cerveja acompanhada de um som de violão, das músicas que cantava no final da tarde, sempre recordando uma mulher enamorada em sua estada em Goiás, "ela era boa demais, eh Marinalva" (todos os nomes utilizados nesta pesquisa são fictícios), rindo e dizendo "vou voltar pra Goiás, Goiás é bão demais". O meu vizinho ficava às vezes muito triste, dizendo que estava com a cabeça ruim, que a vida não prestava, preocupado com o dinheiro que tinha gastado e se culpando por começar mais um dia sem dinheiro, entretanto, orgulhosamente dizendo que não precisava de ninguém: "oh, goiano, as pessoas vem aqui e me dá comida, eu jogo pros meus gatinhos, falam dos gatos, esses gatos, é um inferno, mas dou de comida pra eles, o bichinho não pode passar fome". Contudo, 
depois de alguns meses me perguntou: "você tem um dinheiro ai para...", parou a frase e me disse rindo, que o dinheiro estava difícil. A sua casa era uma construção inacabada e abandonada, acabada de construir por ele com remendos de papelão e pedaços de madeira, deixando o vento ainda fluir da rua. $\mathrm{O}$ vizinho mostrava os desgastes do tempo, seus dentes carcomidos pelas dificuldades sociais, reclamando, às vezes, de dores pelo corpo. O meu vizinho não morava simplesmente em uma casa, morava em um território estabelecido como seu, representado pela necessidade de sobrevivência, e não por uma escritura, ou qualquer papel que simbolizava relação direto com Estado e seus poderes. Lamentava por não ter aprendido uma reza de seu pai baiano para se proteger, dizendo que dava certo mesmo, "a gente rezava $e$ sumia".

Quando perguntei sobre os outros catadores de materiais para reciclagem, criticou-os e me disse que era diferente, que já tinha lugares estratégicos em que encontrava os papéis e me sugerindo, se eu tivesse papel branco, era para guardar para ele, que este papel é que valia dinheiro: "o papel branco" (gargalhava). Quando perguntava da favela, me dizia que não gostava deles, que não moraria lá, em sua casa teria mais privacidade. É com o vizinho que visualizei os primeiros conflitos, antes somente imaginados por meu olhar que rodeava minha casa, a vista para o

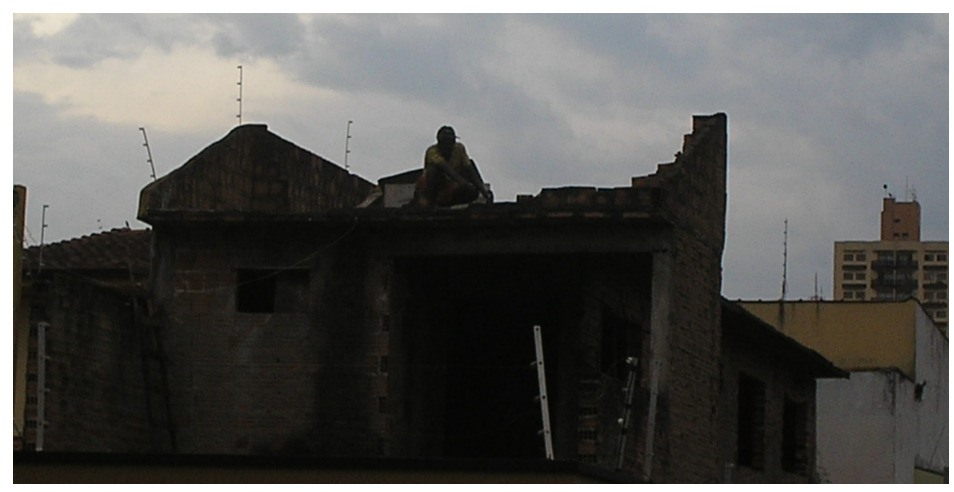
centro verticalizado da cidade, a vista para o Centro de Saúde Escola e para os lugares que iria adentrar. É com este vizinho que pude verificar o medo da aproximação e o choro do distanciamento, um abraço amigável de despedida. 
Do mesmo modo que meu olhar percorria o ambiente externo da minha casa (tanto vista para o centro da cidade quanto para o CSE), me fez ver sobre minha

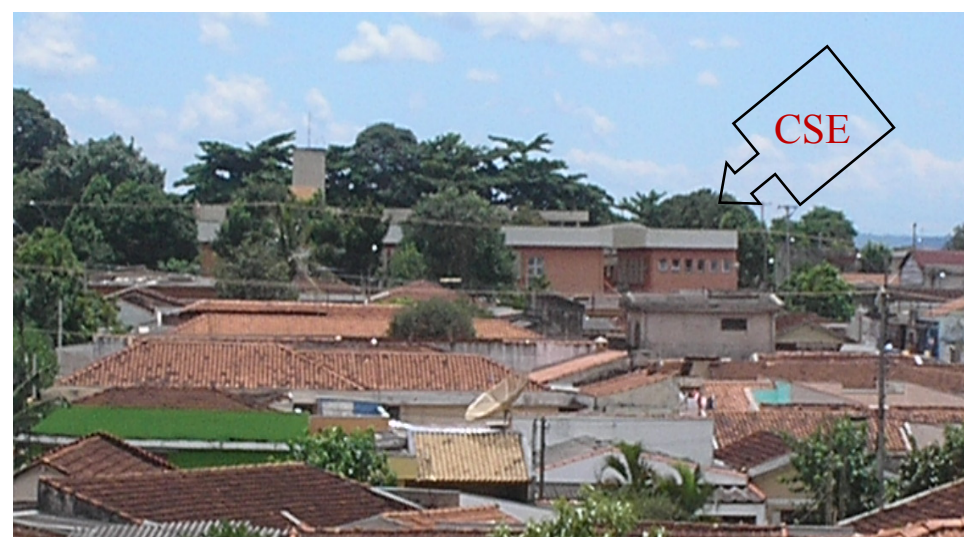
condição de morador de um pequeno prédio e meus vizinhos. Pude perceber que esses vizinhos se mostravam mais distantes do que alguns do lado de fora. Os vizinhos impunham suas impessoalidades, alguns vestidos com roupas brancas: são os profissionais da saúde, estudantes da Universidade de São Paulo (USP). Devido a residência ficar próxima ao campus da USP, muitos estudantes moravam ali perto, sendo comum notar através dos jalecos brancos os alunos dos cursos da área da saúde. As divergências estavam ali ao meu redor, não era uma visão incomum, sendo reveladas das diferentes formas, do encontro de diferentes trajetos de vida.

Assim, estava a minha pessoa possivelmente confundida com a Universidade, porém confusa quanto ao vestuário, visto que não usava um jaleco, não se dizia um profissional de saúde, mas um pesquisador sobre os medicamentos. Esta posição que imiscui profissional de saúde e Universidade leva-me a refletir sobre o que ambos fazem quando adentram os lares da população. Neste sentido, o ambiente que pesquisava já era imposto por uma série de pesquisas, como mostrei anteriormente sobre o número de pesquisas que eram desenvolvidas através do Centro de Saúde Escola (CSE) em conjunto com a USP, como exemplo, posso citar a minha própria pesquisa de mestrado, que tinha sido realizada no Núcleo de Saúde Mental. Além disso, devido a esta área fazer parte de um projeto de extensão da USP, vários alunos e professores faziam estágios e pesquisas. Eram questões que colaboraram para fazer um diálogo singular, como nos revela SILVA (2000, p. 117-118):

“O mito do pesquisador de campo como um 'fantasma' (destituído de sua classe, sexo, cor, opiniões etc.), que não afeta e não é afetado pelo cotidiano que compartilha com seus interlocutores, ou ainda como um herói da simpatia 
e da paciência, cuja missão é 'humanizar' o outro, esquecendo-se de que ele também deve ser 'humanizado' em suas fraquezas e omissões, parece agora exigir novas versões em que o pesquisador encontre um papel mais equilibrado e mais condizente com a situação real da investigação. Afinal de contas, 'nativos de carne e osso', exigem 'antropólogos de carne e osso', pois é nessa condição que ambos se aproximam e fazem aproximar as culturas ou os valores dos quais são representantes no diálogo etnográfico que estabelecem. Saber reconhecer em ambos essa humanidade é uma necessidade cada vez maior num mundo vazado por homogeneidades e diferenças."

Como já tinha percorrido um pequeno trajeto em direção à Farmácia do CSE, agora em diante daria continuidade a este percurso através da área escolhida para a pesquisa de campo. Foi com muito receio que parti de minha casa com o meu gravador, uma máquina fotográfica e um caderno de anotações. Como já tinha apresentado o projeto para o Núcleo de Saúde da Família, ratifiquei que iria pesquisar os consumidores dos medicamentos psicoativos ansiolíticos e antidepressivos de sua área de abrangência.

Inicialmente, compreendendo a Estratégia de Saúde da Família como meio de se aproximar da comunidade, buscando a integralidade da assistência à saúde, acreditando que a centralização na atenção primária seria suficiente para amenizar os conflitos encontrados entre os usuários dos serviços e a farmácia. Contudo, com o caminhar da pesquisa pude observar que por trás do modelo biomédico prevaleciam as relações de poder entre serviço de saúde e população. Observei assim que não era suficiente transformar ações em saúde de curativas para preventivas sem ocorrer mudanças nas relações de poder previamente estruturadas, que contribuem para a permanência de conflitos e desencontros. Desse modo, os conflitos encontrados nas filas da farmácia se estendiam pela comunidade, a falta de diálogo relativo ao consumo de medicamentos prevalecia.

Quando cheguei ao NSF procurei aproximar dos agentes comunitários de saúde, perguntando sobre a área de abrangência do núcleo, sua população e falei que iria visitar algumas pessoas e se predispuseram a ir comigo. Achei que facilitaria a minha inserção na comunidade, esquecendo que a área era composta por uma diversidade de moradores com diferentes condições socioeconômicas. Entretanto, 
afastei do Núcleo à medida que fui observando que em duas entrevistas iniciais que havia realizado com a presença de agente comunitário de saúde os entrevistados pareceram-me inibidos. Cheguei à decisão definitiva de afastar-me do Núcleo, prevenindo que minha pessoa não fosse confundida como pertencente ao serviço de saúde. Esta decisão foi firmada quando visitei uma casa com um dos agentes que logo foi embora, pedi para entrar a sua casa, era um casal de idosos casados recentemente, apresentei e expliquei sobre a pesquisa.

Foi uma entrevista agradável, o marido participando disse com orgulho que era ele que tinha feito o jantar e se eu aceitava, disse que não, dando continuidade a entrevista. Ela estava apressada para ir ao Centro de Saúde Escola (CSE) devido a uma consulta, resolvi acompanhá-la até o CSE. Assim, mesmo no CSE continuei a conversar com ela, contando-me sobre sua vida, seu casamento. No outro dia, passando pela frente de sua casa, seu marido me chamou e disse-me que não estava satisfeito comigo, que eu havia entrado em sua casa, e que ninguém do Núcleo de Saúde da Família havia entrado ainda e que havia perguntado ao Núcleo sobre minha pessoa e dos papéis que carregava e que o agente que tinha ido comigo a sua casa disse que não me conhecia e que também não sabia sobre os papéis que carregava. Logo em seguida, questionou a utilidade do Núcleo e falando que lá não se resolvia nada. E me ameaçou, dizendo que ali eles tinham sua própria justiça, que tinha até investigado onde morava. E proibiu sua mulher de participar da pesquisa, dizendo que era para retirar tudo que ela havia me falado. Procurei resolver o desentendimento e esclarecer novamente sobre a pesquisa, mostrando os papéis que carregava: o termo de consentimento para a pesquisa e que fazia anotações no caderno, relatando sobre a pesquisa. Ele me pediu: "você me dá a sua palavra que está falando a verdade". Com a continuação da conversa este senhor me disse que uma irmã da igreja tinha me visto conversando com sua esposa e que havia lhe dito que eu era o demônio em pessoa e que nós não estávamos falando somente de doença, que era para ter muito cuidado comigo, mas que agora estava achando que a irmã de igreja poderia estar fazendo intrigas, com veneno na língua. Passado alguns dias encontrei sua esposa pela rua e ela me disse que seu marido ficou com medo 
também porque ele tinha falado que temia não receber uma dívida de um homem morador da favela com quem eu já havia conversado.

Este episódio serviu como um alerta sobre a relação do Núcleo de Saúde da Família com a comunidade que aquele casal representava e o que minha pessoa refletia. Pude observar que os laços de confiança estavam abalados. Ao mesmo tempo em que o entrar na casa do casal significou uma maior proximidade, representou também grande desconfiança devido a ninguém ter ainda feito o que eu havia feito, como sentar em seu sofá e conversar sobre questões relacionadas à saúde e a sua vida diária. E o fato de ter acompanhado sua esposa ao serviço, sem a sua presença, aumentou ainda mais suas desconfianças, dizendo quando o encontrei pela segunda vez que sua esposa "não era boa da cabeça". Assim, pude lembrar sua fala durante o inicio da entrevista com sua esposa, ele me disse que ali tinha o tráfico e que era bom porque faziam justiça, que existia uma pessoa que organizava a comunidade: "são corretos, o pessoal do tráfico faz justiça, primeiro manda os meninos conversar, depois ele manda, dá ordem, se a pessoa não comprar e não pagar ele faz justiça também". Resolvido os "males" entendidos, encontrei-o depois e me tratou muito bem, porém, eu não quis mais voltar a sua casa, desse modo, não utilizo as falas dessa entrevista. Temi que ao retornar a sua casa poderia promover uma maior aproximação com o casal, mas aumentar as tensões entre minha pessoa e o Núcleo. Ser confundido como participante dos serviços de saúde representa um limite: o de não poder conversar algo além de doença, o silêncio sobre sua vida torna-se uma proibição defensiva. Nesse sentido, algumas casas não deixavam que os agentes entrassem em suas casas, ficando somente nas portas, nas garagens.

Este acontecimento envolvendo minha segunda entrevista tem alguns pontos relevantes, como a dificuldade dos serviços de saúde de terem um diálogo amigável com a população. Comecei a me questionar sobre este desacordo, que foi melhor esclarecido à medida que circulava em outras partes da área pesquisada. Então, a localização desses moradores e suas condições socioeconômicas foram preponderantes. O diálogo com o senhor mostrou-me que ele exercia o papel de defensor, foi ele que me chamou e proibiu sua esposa de continuar na pesquisa, 
colocando-a como incapaz de se defender. Além disso, a sua casa se localizava nas bordas da favela, numa rua asfaltada limítrofe da rua de terra da favela, lugar em que o senhor já havia morado. As ruas que circulavam a favela tiveram significados relevantes ao notar uma concentração de pessoas que utilizavam os medicamentos psicoativos. Estas ruas revelaram-me um primeiro conflito: a presença ou a ausência do Estado e do tráfico de drogas.

Desse modo, pelo fato de ser uma favela em processo de urbanização enquanto alguns moradores diziam que o "Estado é caro, quer dinheiro que a gente não tem", outros valorizavam as ações do Estado, mas reconhecendo os interesses políticos, demonstrando que as ações do Estado seriam uma troca, uma negociação não falada, mas que a urbanização somente ocorreria através dessa troca, dizendo que eles não pagariam a urbanização, mas a de outra parte "favelada" da cidade à medida que sua parte fosse urbanizada. Com a urbanização, fixaram a uma das vias de acesso à favela uma placa dizendo que ali seriam beneficiadas 369 famílias através da COHAB.

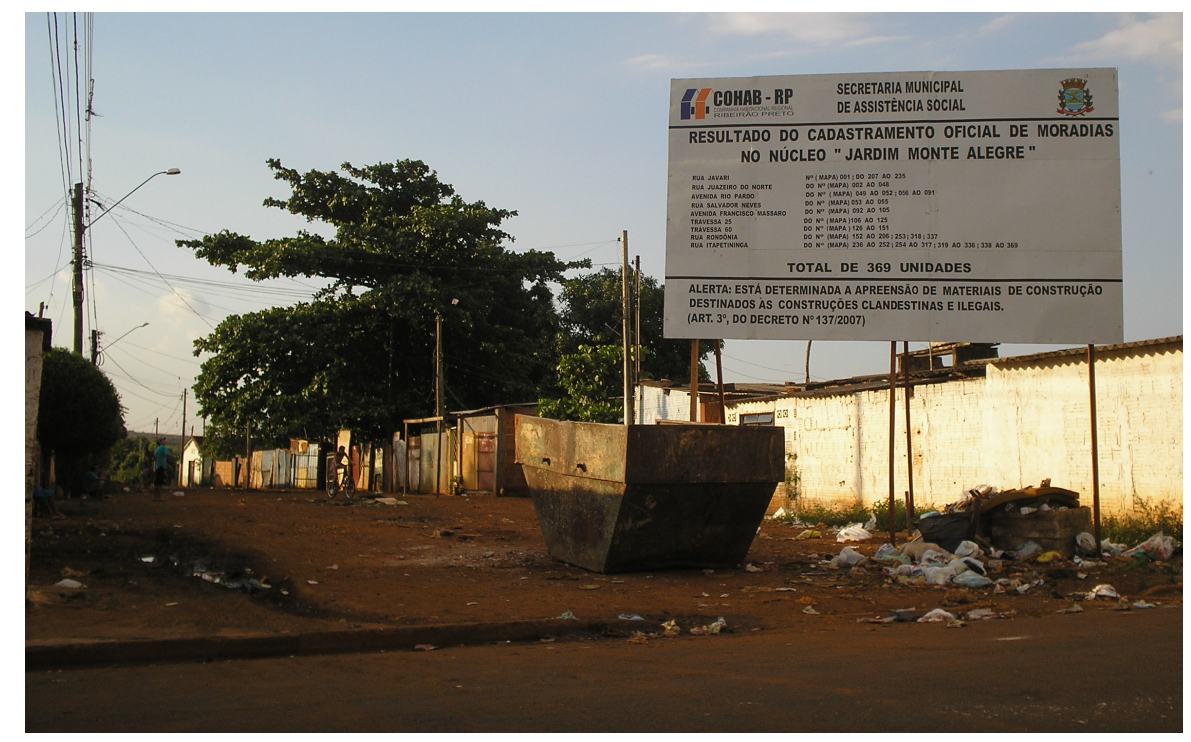

As ações do tráfico de drogas são consideradas inofensivas por muitos moradores quando comparadas com um passado cheio de atritos, entre "guerras" entre os traficantes, ocorrendo várias mortes, sendo uma das justificativas para o uso dos medicamentos pesquisados. Todavia, o papel dos traficantes foi lembrado também como um tempo bom, "em que ninguém roubava ninguém", "que tinha 
justiça". Nesse sentido, mesmo o tráfico não tendo o mesmo vigor de antes, compreendi porque o senhor que eu havia visitado dias antes tinha me ameaçado fazendo uso dos traficantes para impor sua vontade: confiava-se mais nos traficantes do que no Estado (e mesmo a minha posição estava mais perto do Estado, sendo visto como pertencente a uma instituição como a Universidade e a um serviço de saúde público).

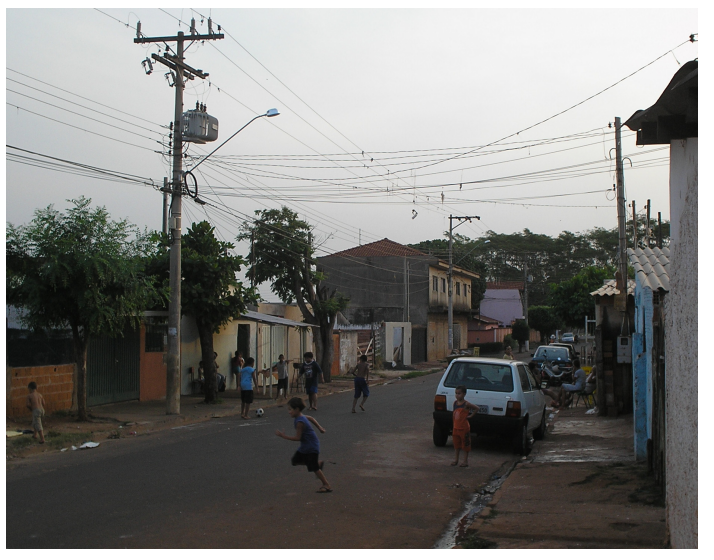

caminharem por essa rua exercerem diversos julgamentos, revelando fronteiras socioculturais. Assim, os olhares dirigidos à favela poderiam ser vistos como um espetáculo por estudantes, como um "lugar de perdição" e de um exemplo a não ser seguido por outros moradores não pertencentes à favela.

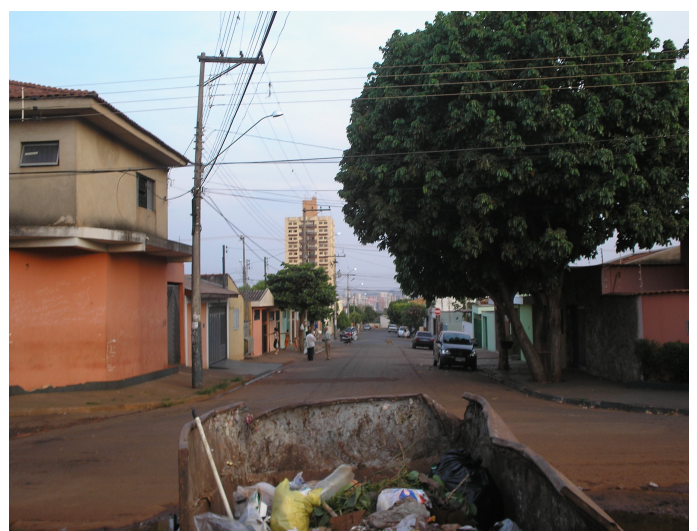

Compreendi esta rua como um lugar de fronteira, um ponto de conflito entre o mundo asfaltado, urbano com o mundo rural, de terra. Desse modo, as ruas que dividem a pequena favela com seus moradores serviam para outros moradores, estudantes e estagiários dos diferentes cursos de graduação ao

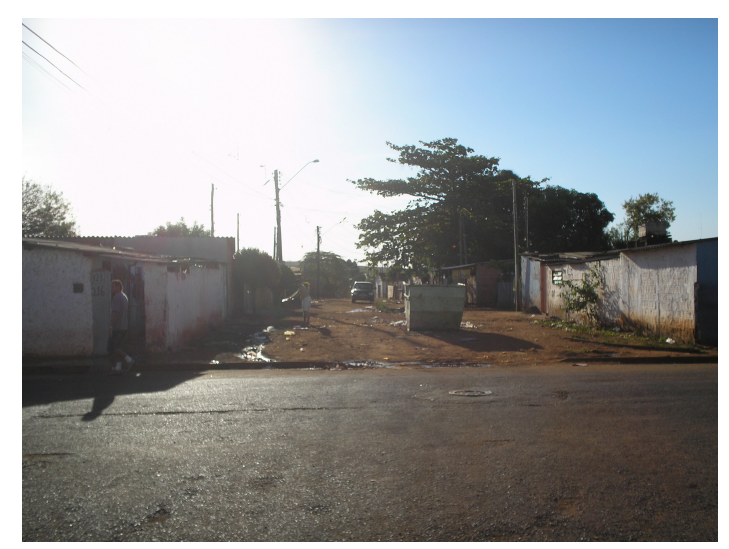

A favela era rodeada por diferenças, marcando uma diversidade de estilos de vida. O bairro ao qual pertencia estava caracterizado pela parte mais antiga, composta por moradores que geralmente se diziam ser daquele bairro ou da cidade de Ribeirão Preto, "os do lugar". 
As outras partes que faziam fronteira, o bairro de casas mais luxuosas e das casas da COHAB, eram separadas por uma avenida cada um, sendo que a avenida que separava o bairro das casas luxuosas era mais larga e possuía um canteiro central. Pode-se assim notar que ocorrera um alargamento das ruas limítrofes com a favela de acordo com as condições socioeconômicas.

A rua, ao longo da história, teve incursões para sua racionalização, procurando esvaziá-la, porém, nas bordas da favela isso não acontecia, sendo uma rua movimentada, com pessoas sentadas na porta de suas casas, com os bares abertos e as pessoas sentadas em cadeiras na calçada. De acordo com MAGNANI (1993, p. 46) a rua é um lugar importante para a etnografia, pois: "É a rua que resgata a experiência da diversidade, possibilitando a presença do forasteiro, o encontro entre desconhecidos, a troca entre diferentes, o reconhecimento dos semelhantes, a multiplicidade de usos de olhares - tudo num espaço público, e regulado por normas também públicas". Cada rua irá possuir particularidades, podendo ser categorizadas, classificadas de acordo com seu uso e forma. Como se pode observar nesta pesquisa, as ruas nos bairros urbanizados tendem a serem "mortas", vazias, separadas do espaço das casas, mas como MAGNANI (1993) diz, a rua guarda suas experiências, sendo aplicadas em diferentes locais da cidade, e as ruas preservam características socioculturais onde são identificadas pessoas, locais coletivos, indo desde um shopping a uma padaria. É este encontro e desencontro entre rua e casa, o público e o privado, que também descreverei como lócus de um conflito que se torna medicalizável. Inicialmente, tudo pode parecer familiar, por isso a necessidade de aprofundamento, não deixar que o senso comum ofusque o olhar e impeça de problematizar a realidade, em suas conexões com outros com toda a estrutura social (MAGNANI, 1993). Através da observação participante, trato do diálogo entre diferentes ruas, desde uma rua que quase não fala, até uma rua expressiva, pessoal, uma que se nega a calar e outra que se nega a falar, ruas que fazem além de espaço social, espaço de conexão entre diferenças. São ruas medicalizadas. 


\subsubsection{Entre esquinas: lugar de julgamentos}

Apesar de inicialmente a pesquisa de campo não ter feito esse percurso em torno da favela, ele foi se formando à medida que discutia o consumo dos medicamentos psicoativos e interagia com a população, levando-me a ter este caminho como modelo que estava seguindo desde o início da pesquisa, como a descrição que fiz do campo visual que tinha de minha casa, mas que coincidia com as modulações interativas entre população e estrutura urbana. Assim, o meu primeiro trecho iniciou entre a favela e os moradores de seu bairro considerados em sua maioria antigos moradores da cidade de Ribeirão Preto.

A rua aqui é assim analisada como espaço social, particularizado pelas pessoas que a freqüentam, não sendo a estrutura urbana apenas um cenário, mas pontos de comunicação com a sociedade (MAGNANI, 2002). Desse modo, as partes desses bairros ou os bairros inteiros são vistos como comunicantes com o restante da cidade, estruturas que se dialogam em conjunto com a população, revelando diversidade e diferenças socioculturais. Nesse sentido, meu caminho inicial realizado através da pesquisa se formou outro ao se unir com a população dos bairros, levandome a rever o percurso institucional que fiz através da Universidade e do serviço de saúde.

A rua que divide a favela da parte mais antiga do bairro apresenta-se enganosamente ao revelar lugar como se todos fossem compreendidos por serem conhecidos e por isso coletivamente donos da rua. Se olharmos somente os bons momentos de lazer, de diversão, de amizade, esta rua pode até ganhar aparência de um "pedaço", como diz MAGNANI (2002), lugar que possui um código de reconhecimento entre as pessoas suficiente para delimitar singularidades, existindo uma circulação que identifica e é identificada. Porém, se olharmos também a rua 
como ponto de encontro dos diferentes pode-se ver ali um lugar de conflito, lugar de tentativa de diálogo entre os diferentes, levando a notar as desigualdades socioculturais. Esta rua pode ser assim entendida como um "pedaço" de lazer, mas por alguns momentos, dissimulando os conflitos existentes. O "fora de casa", de acordo com MAGNANI (2002) pode ir além da vizinhança, podem se encontrar "pedaços" em diferentes lugares na cidade em que pessoas remetem a um mesmo estilo de vida, identificam-se como iguais, tendo um mesmo habitus, mas não construído na sua vizinhança. Supõe-se que outras pessoas vivendo nas mesmas condições em que encontrei nessa rua se imiscuíam mais do que outras pessoas. Assim, a rua aqui é um pedaço conflituoso, havendo semelhanças e diferenças, encontros e desencontros.

É pela visualização desses conflitos que esta pesquisa adquiriu uma nova construção, realizada pelo encontro entre pesquisador e pesquisado, entre todas as pessoas envolvidas no campo da pesquisa, analisando-o através de uma perspectiva relacional envolvendo homens e mulheres e seus cursos de vida. Desse modo, pude verificar fusões do distante, pessoas vindas de diferentes Estados do Brasil, como Minas Gerais, Rio Grande do Norte, Bahia, e que formaram um lugar de encontro, de semelhança, entretanto, um lugar ou ponto de disputa, de conflito sociocultural. Alguns moradores das favelas não se restringiam aos bares internos na favela, iam beber nos bares existentes nessa rua, jogar bilhar, freqüentar bailes. A rua torna-se lugar de relaxamento, transforma-se em remédio, como diz um rapaz que ao pedir uma dose de cachaça exclamou: "me dá uma farmacinha aí".

A relação entre favela e asfalto foi estudada por PICCOLO (2006) na cidade do Rio de Janeiro. De acordo com esta autora, a favela é vista como lugar esteticamente feio em oposição a um mundo asfaltado aceito como correto, normal para a cidade. Esta oposição fixa a favela como um lugar construído através da associação entre dificuldades econômicas e criminalidade, estigmatizando seus moradores como perigosos, criminosos, levando a ser vista como um lugar homogêneo, como explica a autora:

"Nessa (di)visão, que toma a violência como ponto de interseção da cidade, as favelas são vistas como homogêneas, símbolos da ilegalidade, fonte de 
muitos problemas e de insegurança; e o 'asfalto' também é visto homogeneamente, como símbolo da legalidade, da ordem, da solução e do medo. Medo esse que inclui ser 'tomado de assalto' pelos moradores das favelas. O contraste passa também por uma disputa de classe, de visões de mundo e estilos de vida." (PICCOLO, 2006, p. 336).

Assim, quando cheguei à favela pela primeira vez, poderia dizer que ali era um ambiente homogêneo de mulheres e crianças, foi somente com uma visita no crepúsculo do dia que pude ver os homens chegando: trabalhadores da construção civil, da zona rural, das plantações de cana, como vigilantes, etc.

Devido à "mancha" que o termo "favela" ganhou, PICCOLO (2006, p. 348) sugere que seja substituído pela categoria "comunidade" por esta ser notada como “estratégia discursiva para dirimir os conflitos, pois é nela que o Estado, ONGs e outras instituições podem atuar, através dos projetos sociais". Seria na comunidade que os benefícios sociais chegariam, enquanto na favela o Estado estaria por si ausente.

Ora, pode-se dizer que o Estado esteve sempre presente na favela, pois ele também é ordenador de uma sociedade que produz mecanismos geradores de condições propícias para o desenvolvimento de favelas. As políticas sociais também colaboram para a produção de desigualdade e favorecimento de determinados grupos sociais. Não estaríamos aqui produzindo uma espécie de perdão a este processo gerador de favela, que inclui toda a sociedade, dizendo que a favela só existe porque o Estado esteve ausente. Em minhas caminhadas por esta favela, pude ver ali os agentes comunitários de saúde e outros profissionais, pude ver policiais fazendo suas rondas, pude ver a vigilância epidemiológica combatendo o mosquito da dengue e dizendo que haviam feito um "arrastão" na favela contra o mosquito, retirando seus criadouros. As ações do Estado estavam ali presentes e mesmo assim não ouvi a referência ao termo "comunidade".

A favela de acordo com PICCOLO (2006) passou por diversas conotações relacionadas às dificuldades econômicas e suas conseqüências sobre a qualidade das moradias, da falta de estruturas com faltas de ruas e de esgoto, como lugar de refúgio para ladrões e traficantes. Porém, adoto o termo "favela" devido a este ser assim dito 
pelos próprios moradores, inclusive, ao relatarem sobre quando outro grupo entrou em confronto com a "favela", este também foi chamado de "favela" devido ao tipo de moradia ser de barracos, mesmo as pessoas deste grupo morando em uma propriedade particular. A favela passa por conotações relacionadas ao tipo de moradia, à falta de uma infra-estrutura com rede de esgoto, elétrica, desemprego, etc, mas homogeneizar o termo estaria correndo o risco de estar também homogeneizando os moradores, provocando equívocos nas interpretações sobre a favela.

A favela que pesquisei pode ser também erroneamente confundida com gueto, porém apresenta semelhanças. Pois, de acordo com a definição de gueto fornecida por WACQUANT (2004) partindo da sociedade norte-americana, o gueto apresenta determinadas características em consonância com a favela:

"Podem ser detectados nesse momento inaugural os quatro elementos que constituem o gueto, isto é, o estigma, o limite, o confinamento espacial e o encapsulamento institucional. O gueto é um meio sócio-organizacional que usa o espaço com o fim de conciliar dois objetivos antinômicos: maximizar os lucros materiais extraídos de um grupo visto como pervertido e perversor e minimizar o contato íntimo com seus membros, a fim de evitar a ameaça de corrosão simbólica e de contágio" (WACQUANT, 2004, p. 157, grifo do autor).

Apesar de seus moradores serem estigmatizados como perigosos, vivendo em uma determinada área, eles tem uma ação voluntária, sendo identificados como "moradores da favela" e do seu modo de vida, vivendo em uma área limite, porém não separada socialmente do restante da cidade, estando interligada, a favela não possui uma estrutura organizacional como os guetos, que também se fecham através de suas instituições. O que se pode sugerir é que a favela pretende ser um gueto, não como realmente um gueto é definido por WACQUANT (2004), violentamente fechado, segregando um grupo social étnico-racial. Na favela, os moradores formam laços de solidariedade voltada para sobrevivência, enquanto no gueto estes laços vão além dos fins econômicos, eles ocorrem também para preservar sua cultura e instituições próprias, como uma cidade paralela (WACQUANT, 2004). A favela aqui faz parte de um processo socioeconômico envolvendo afirmações de distinções, 
destacando aquelas que já são formadas pelas diferenças socioculturais, por isso a favela pretende ser gueto, pois ao mesmo tempo em que é impedida pelos laços entre os diferentes grupos sociais existentes no Brasil, é pretendida pelo processo de distinção, promovendo a separação, e enquanto as diferentes pessoas moradoras de uma favela que se encontram vindas de diversas partes do país querem preservar seus habitus, os moradores que circunvizinham a favela querem se distinguir destes. Em uma sociedade onde a maioria da população possui dificuldades econômicas, os muros e cercas elétricas levantados mudam de posição, são os mais abastados que se dizem diferentes e os valores culturais da maioria da população pobre são questionados, fazendo acirrar os conflitos entre estes e o destaque das diferenças socioculturais. A favela é aqui vista como construção histórico-social que permeia os discursos como justificativa entre os diferentes grupos sociais para um sobrepor o outro. A favela mostra-se como encontro da diversidade, como o encontro de diferentes famílias que vieram de várias regiões brasileiras.

A favela, como o gueto, é aqui compreendida como espaço de resistência às coerções de um grupo social sobre o outro, diferenciando-se pelo fato da favela estar submissa às mesmas instituições em que toda a cidade está sujeita. $\mathrm{O}$ gueto, como a favela, é uma forma de segregação social, ambos fazendo parte de políticas públicas que favorecem determinado grupo social frente aos demais, colaborando para formação de distinções apoiadas pelo Estado, como WACQUANT (2004, p. 158, grifo do autor) explica sobre o surgimento do gueto negro na sociedade norteamericana: “(...) uma forma muito peculiar de urbanização modificada por relações assimétricas de poder entre grupos etnoraciais: uma forma especial de violência coletiva concretizada no espaço urbano. (...) o gueto negro foi reconstruído de cima para baixo por meio de políticas públicas de habitação, renovação urbana e desenvolvimento econômico das periferias (...).”

WACQUANT (2004, p.159) diz que o significado de gueto não deve ser confundido com empobrecimento de classe trabalhadora, pois estão em "cápsulas étnicas dedicadas a manter um grupo excluído numa relação de subordinação separatista”. Porém, pode-se notar um processo que se assemelha, produzindo e 
reafirmando diferenças sociais, no entanto, aparentemente menos contundentes, mas que se pretendem chegar ao limite do corpo, da vida, sendo realizado quando se torna possível, dependendo das relações de poder e resistência. Aqui, o Estado está também presente, ora formando bairros, como os feitos pelas COHAB, o que chamo aqui de "cohabização", que se distancia do conceito de gueto devido aos estreitos laços que se tem entre os diferentes grupos sociais brasileiros, o que facilita laços sociais voltados para a exploração da força de trabalho de seus moradores. Estes laços não estão livres de conflitos, o que facilita a sua medicalização, pelo encontro de diferentes grupos sociais através dos serviços de saúde. Acredito que tanto os bairros feitos pela $\mathrm{COHAB}$ como a favela fazem parte de um processo segregacionista, porém separados por um processo de alienação inserido a seus moradores como espécie de destino, considerando-se insuficientes mais do que insatisfeitos.

As imposições de um estilo de vida não se restringem aos fatos momentâneos, são originadas de projeções sócio-históricas, construções de modelos e normas que interagem estrutura social com o corpo, formulando um tipo de personalidade. Para SIMMEL (1976), a sociedade, antes baseada no convívio interpessoal e em um ritmo mais lento como o da vida rural e das pequenas cidades, transformou-se para um oposto que o contrasta, com os excessos que as grandes cidades proporcionam à vida, que provocam tendências ao esgotamento do corpo e mudanças na personalidade. Os sentidos do corpo são esgotados, os estímulos são intensificados ao máximo e levando ao que o autor chama de atitude blasé, formando barreiras à sensibilidade e promovendo a racionalização da vida cotidiana, objetivando comportamentos e fazendo agirmos pautados no pensamento calculado, na intelectualidade que impede a ocorrência de interações sensíveis, quantificando a vida através de uma associação à quantidade de dinheiro, resumindo-se aos números:

"Os mesmos fatores que assim redundaram na exatidão e precisão minuciosa da forma de vida redundaram também em uma estrutura da mais alta impessoalidade; por outro lado, promoveram uma subjetividade altamente pessoal. Não há talvez fenômeno psíquico que tenha sido tão incondicionalmente reservado à metrópole quanto a atitude blasé. A atitude blasé resulta em primeiro lugar dos estímulos contrastantes que, em rápidas 
mudanças e compressão concentrada, são impostos aos nervos. Disto também parece originalmente jorrar a intensificação da intelectualidade metropolitana. (...). Uma vida em perseguição desregrada ao prazer torna uma pessoa blasé porque agita os nervos até seu ponto de mais forte reatividade por um tempo tão longo que eles finalmente cessam completamente de reagir. (SIMMEL, 1976, p. 15-16)."

A pessoa blasé é para SIMMEL (1976) sem reação por ser esgotada, impessoal, indiferente ao outro, as grandes cidades consomem os sentidos. Quando observo a favela e o modo como as pessoas lidam umas com as outras e os contrastes, vejo como lugar descritível, com as pessoas revelando suas identidades, sua condição histórica, um "lugar antropológico" em oposição a um "não-lugar" descrito por AUGÉ (1994), este, um lugar impessoal, não identificando o Outro como pessoa, não sendo localizável a partir deste lugar, geralmente marcado por encontros das diferenças e pelo comércio de mercadorias. Anoto os conflitos existentes entre estas duas esferas da cidade, a imposição dos "não-lugares" aos "lugares antropológicos", levando a construções de modos de vida voltados para o consumo, para a solidão, levando a uma construção simbólica de muros ao redor das pessoas, revelando somente sua estrutura, um conflito que é contundente aos moradores de grupos populares, e vejo a cidade indiferente aos sentimentos que SIMMEL (1976) expôs. Desse modo, vejo a favela como resistência ao indivíduo blasé, porém ocorre uma espécie de "blaseficação" quando a cidade chega à favela e impõe impessoalidades, toda a vida dos moradores organizada em uma vida que aflora sensibilidades, colaborando para a formação de redes de solidariedades e resistências que são enfraquecidas. Como vi, ocorrem resistências, porém para formar um sujeito blasé e transformar os resquícios de uma vida das pequenas cidades e da zona rural, os medicamentos psicoativos são colaboradores, pois toda a violência que grupos populares estão sujeitos não foi suficiente, busca-se extremidades opostas para formar uma atitude blasé, fazendo os efeitos dos medicamentos ansiolíticos e antidepressivos a outra extremidade, ocorrendo assim um esgotamento. A pessoa se torna insensível não apenas pelos efeitos dos medicamentos, mas pelo choque das extremidades que leva ao seu esgotamento. Os medicamentos são aqui vistos como auxílio a uma vida organizada sobre o intelecto, 
por isso, quando se tomam os medicamentos na condição de tratamento de conflitos, eles contribuem para impor um modo de vida predeterminado, originado das relações de poder e de seu caráter hegemônico. A favela torna-se não apenas um lugar de afastamento das relações de poder, mas de resistência a um estilo de vida não aceito, a favela é também um refúgio. A urbanização ou "cohabização" vão colaborar para uma atitude blasé, o que gera conflitos ao construir em seus moradores um novo modo de vida, e os medicamentos psicoativos colaborarão para esta construção ao se tornarem uma terapêutica para estes conflitos gerados. As filas da farmácia também são um lugar de "blaseficação", não só pelos medicamentos, mas pelos comportamentos que tanto a fila impõe como o modo como as informações são racionalizadas, em um tempo calculado.

Os conflitos são assim temporais, geracionais, tempos e movimentos diferentes serão causas de conflitos medicalizáveis. Movimentos contínuos, formando um curso de vida, trajeto particularizado que "junta" acontecimentos e memórias, irão confrontar com os movimentos rápidos que a cidade irá se pautar, do esvaziar-se, do consumir e ser consumido pelos desgastes envolvendo a cidade, do esquecimento. As alterações na relação tempo/espaço não são aqui somente originadas da inserção de tecnologias, da proximidade virtual, dos meios de transportes. A relação tempo/espaço se diferencia devido à exploração de um grupo social sobre o outro, de um modelo que coage e impõe ao outro um modo de vida que o leva aos extremos para sobreviver. São pessoas que tiveram que mudar de seus Estados, das pequenas cidades, do meio rural para ir morar em Ribeirão Preto em busca de melhores condições de vida, são tempos e espaços diferentes que se encontram e formam fronteiras medicalizáveis.

Os cursos de vida não são vistos como algo linear e como se velhice fosse uma etapa, analiso os trajetos histórico-sociais percorridos, por isso, os choques causados por movimentos dispares, não lineares. O corpo aqui não se degenera porque somente envelhece, é também explorado, o envelhecimento biológico somase ao curso de vida. 
O curso de vida é compreendido como processo desenvolvido pela trajetória percorrida no envelhecer, pelas experiências e diferenças de conhecimentos acumulados na dinâmica social e cultural, que faz do curso de vida um processo de “desinstitucionalização" da vida como uma divisão em etapas (BASSIT, 2000). O curso de vida passa de acordo com BASSIT (2000) a transformar qualquer acontecimento da vida a ser problematizado, analisando tanto as experiências passadas como os projetos para o futuro. Desse modo, os medicamentos transformam-se em foco para discussão sobre o corpo, não como dirigidos a uma determinada idade, mas orientados para o consumo e produção de valores relacionados ao corpo e ao controle dos conflitos gerados pela interação entre social, cultural e biológico. O corpo, ao distanciar-se como projeto de etapas institucionalizadas, que impunham disciplinas orientadas de acordo com a idade, torna-se manipulável segundo os desejos de quem o possui, passando a ditar-se quando se considera insuficiente (EHRENBERG, 1995), promovendo que o uso de medicamentos também seja autônomo ao moldar o corpo, e não reduzido às prescrições fornecidas pelos serviços de saúde. Os limites passam a ser o limite do corpo e não de idade.

O consumo de medicamentos antecipa estados considerados doentes, o uso passa a ser preventivo, mas não para as doenças diagnosticadas pelos serviços de saúde, mas pelas concepções sobre os estados do corpo de cada um. As tecnologias, aqui concentradas nos medicamentos, se inserem na relação da formação de um corpo, colaborando para particularizar sua construção. O corpo, ao ser inserido de tecnologias, perde o seu curso considerado natural e se posiciona como construção, como FEATHERTONE e HEPWORTH (2000, p.123), descrevem:

"Se considerarmos a relação entre os seres humanos e a natureza, então faz sentido não ver a tecnologia como um terceiro tempo separado, de certa forma fora da relação. Ao contrário, precisamos vê-la como uma relação na qual a natureza e a constituição humana corpórea transformam-se por meio da tecnologia, o que sugere que é melhor conceber a natureza, o corpo humano e a cultura como processos. Pela tecnologia, os seres humanos podem não só desenvolver modelos de conhecimento teórico e prático que permitem controlar e dominar a natureza e também nossos próprios corpos, mas o processo de transformação é também um processo que envolve a fabricação. 
Ou seja, não se deve considerar a tecnologia simplesmente como um conjunto de ferramentas ou técnicas para o domínio mais eficiente da natureza, mas como uma abertura de possibilidades para que os seres humanos criem naturezas mais construídas. Recriar a natureza é um dos sonhos da tecnologia na tradição ocidental."

Nessa perspectiva, as tecnologias estariam favorecendo a fabricação de um corpo que explora seus limites. O que descrevo aqui é como os medicamentos psicoativos colaboram para coordenar cursos de vida, manipular o corpo de acordo com as vivências de grupos populares, questionando como os limites do corpo são explorados. Desse modo, problematizo como e qual corpo que os medicamentos facilitam a fabricação, o que favorece críticas de como as tecnologias chegam nos diferentes grupos sociais e sua ligação com as relações de poder existentes na sociedade.

As partes, aqui vistas como bairros por fazerem parte de diferentes bairros, que fizeram parte da pesquisa, o das casas $\mathrm{COHAB}$, favela, bairro de casas luxuosas e o bairro antigo, são bairros que estão envoltos por situações conflituosas, sendo estas as principais justificativas de seus moradores para o consumo de medicamentos psicoativos (ansiolíticos e antidepressivos). São a estes conflitos que me detenho, conflitos que já havia verificado nas filas na farmácia, originados das diferenças socioculturais. Estes conflitos estão marcados pela busca de melhores condições de vida envolvendo os grupos populares. A observação participante percorreu essas diferenças partes, sendo a das casas COHAB não coberta pelo Núcleo de Saúde da Família, e em relação à parte do bairro das casas luxuosas não foram incluídas as entrevistas lá realizadas. 
Para melhor visualizar as divergências e contrastes entre as áreas pesquisadas, a imagem seguinte ilustra a relação entre estas áreas: a favela, o bairro das casas $\mathrm{COHAB}$, o bairro das casas luxuosas, e o bairro antigo. As regiões em cor cinza na imagem seguinte representam as ruas asfaltadas que dividem as áreas pesquisadas. Além disso, em seguida, são mostradas fotografias das áreas pesquisadas.

\section{Bairro das casas COHAB}

Bairro das casas luxuosas

Favela

Bairro antigo 
A rua entre a favela e o bairro antigo

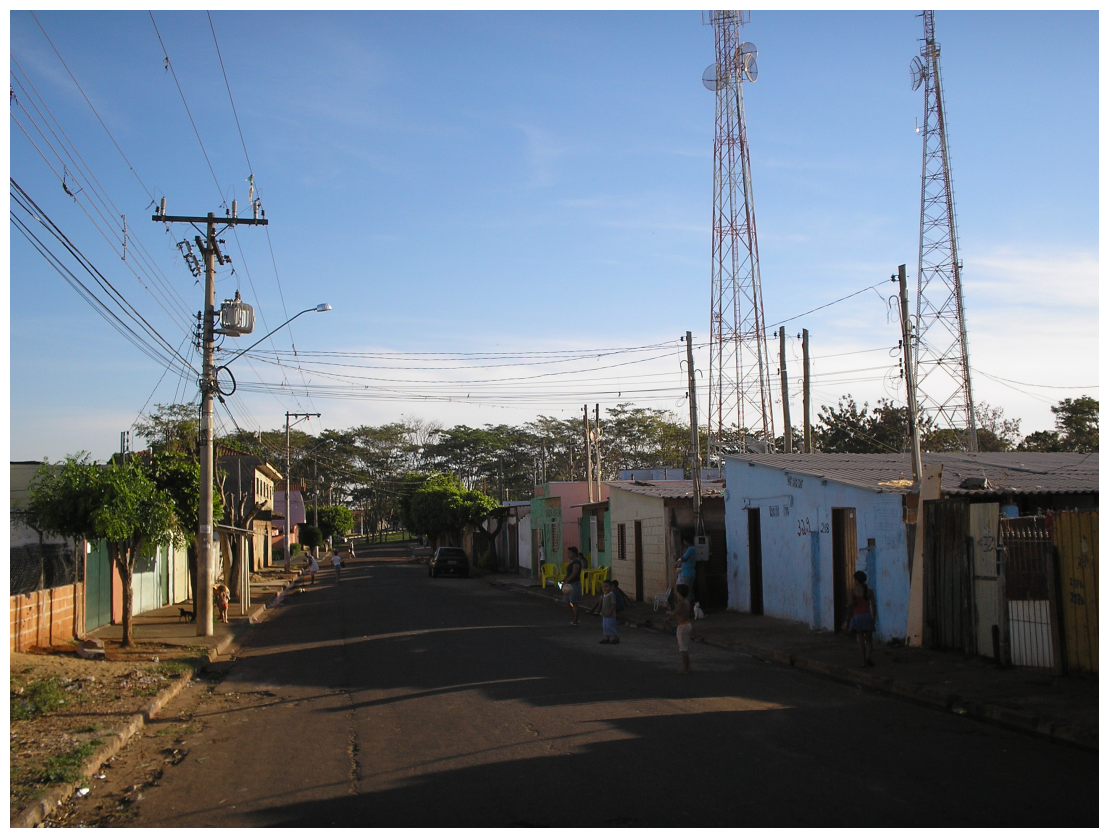

A rua entre a favela e o bairro de casas COHAB

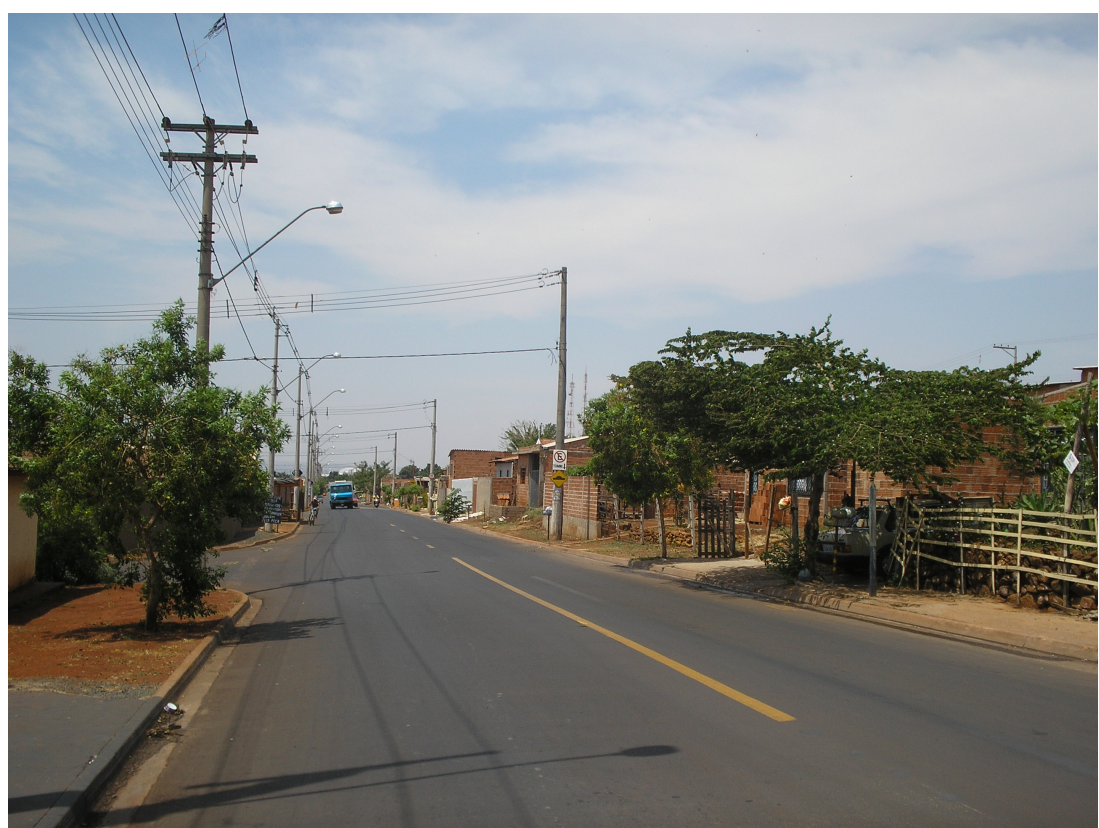


A avenida entre o bairro de casas luxuosas e as áreas do bairro antigo e da favela
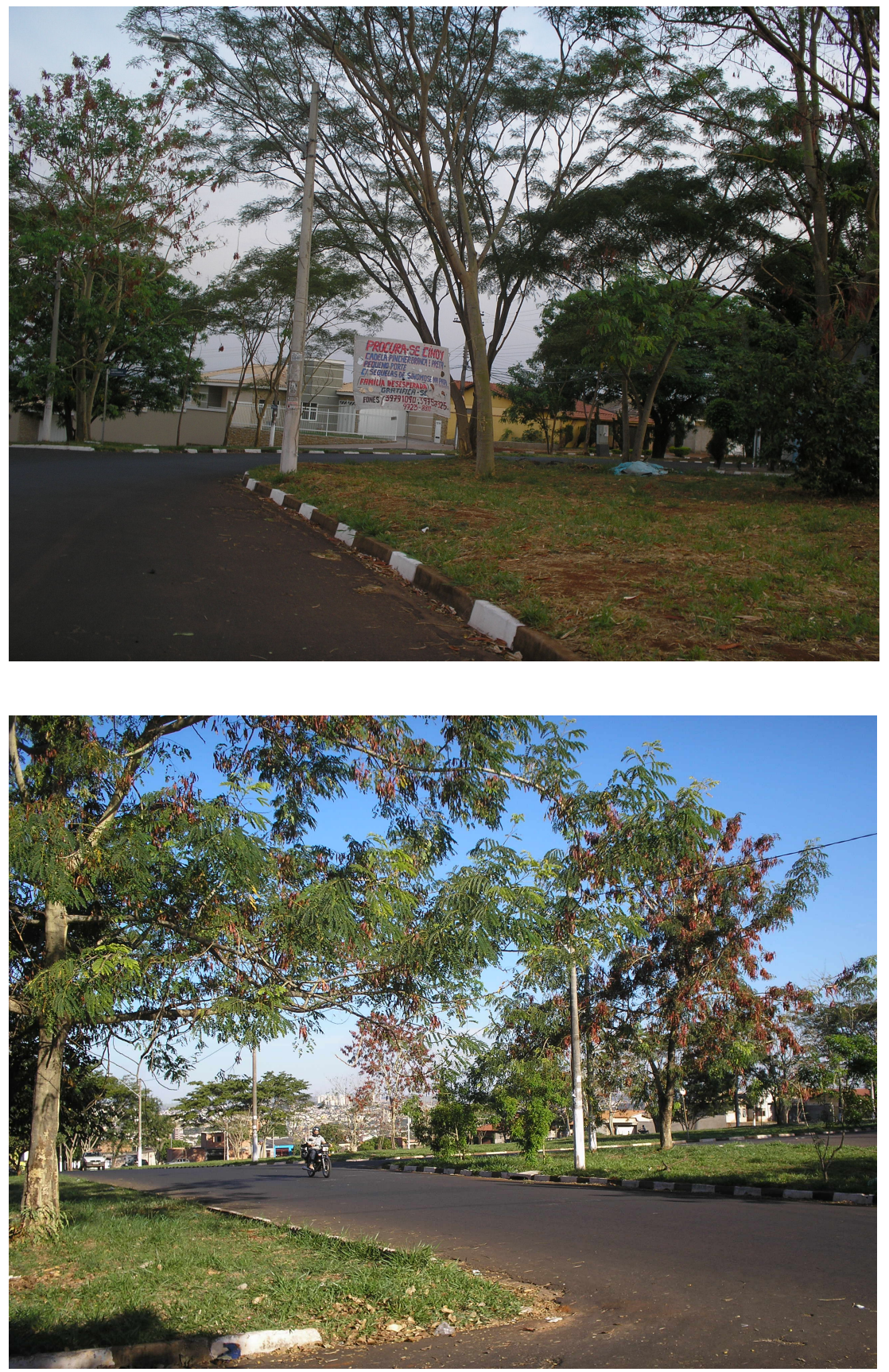


\section{A área da favela}
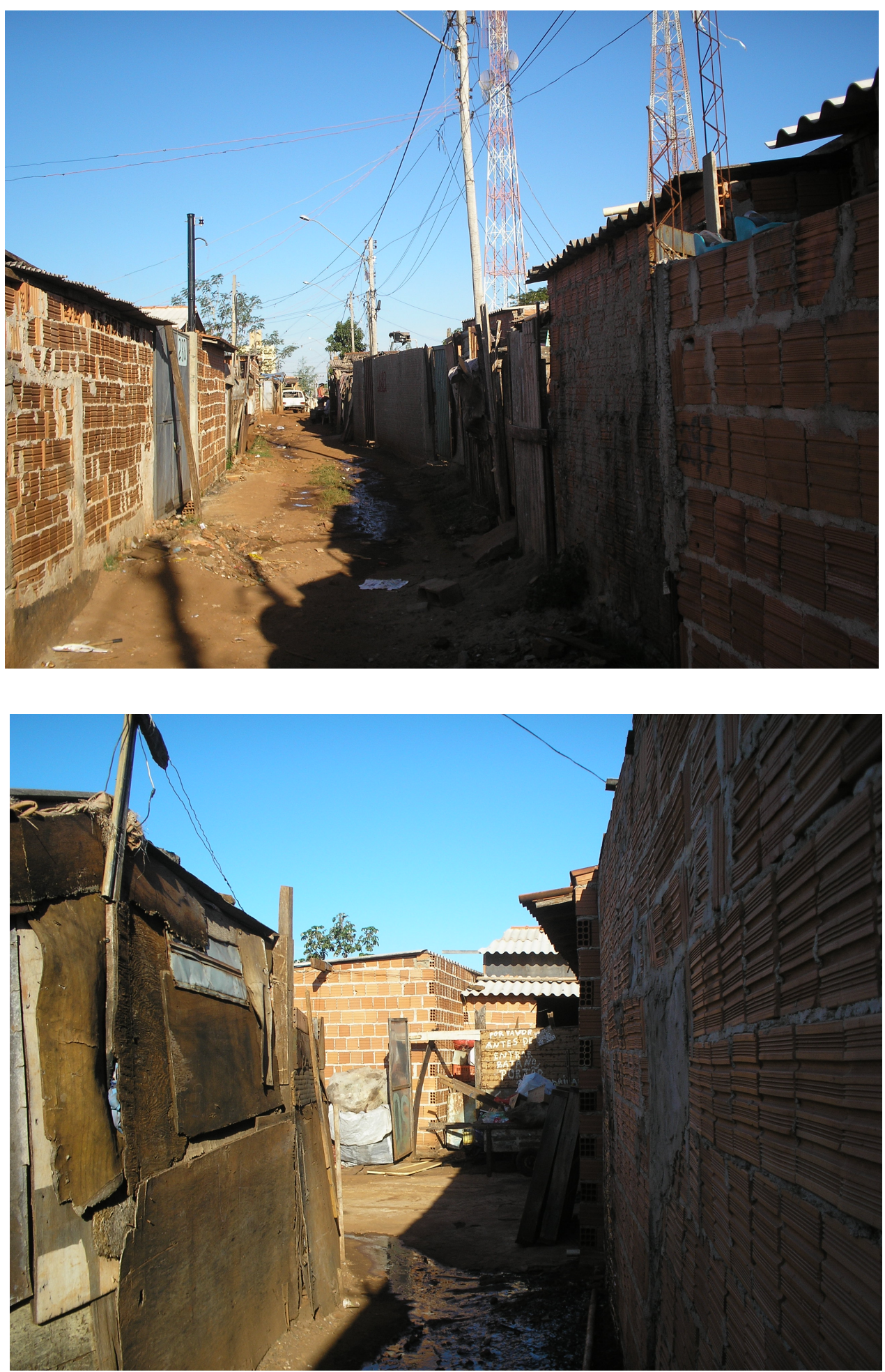

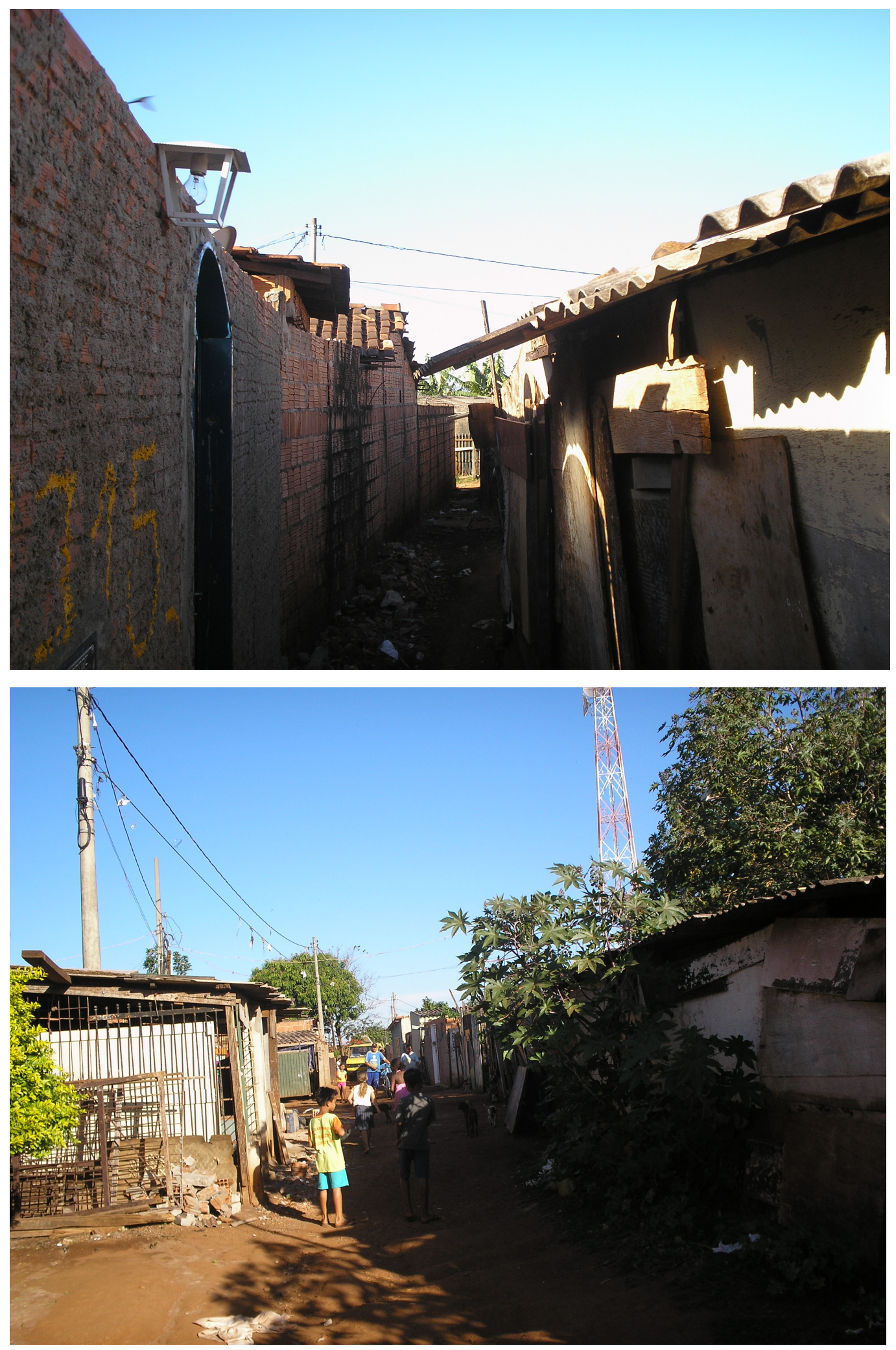

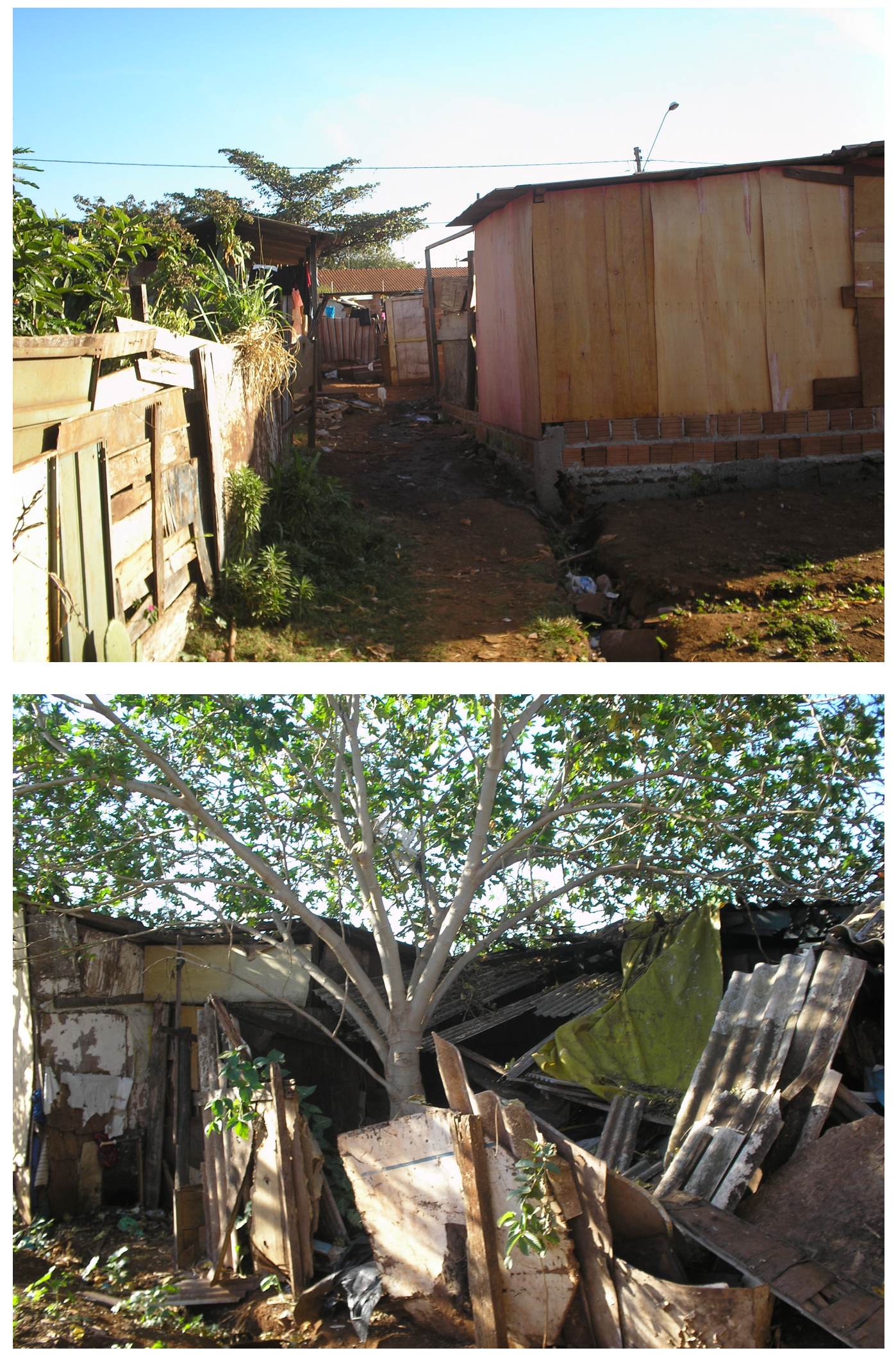

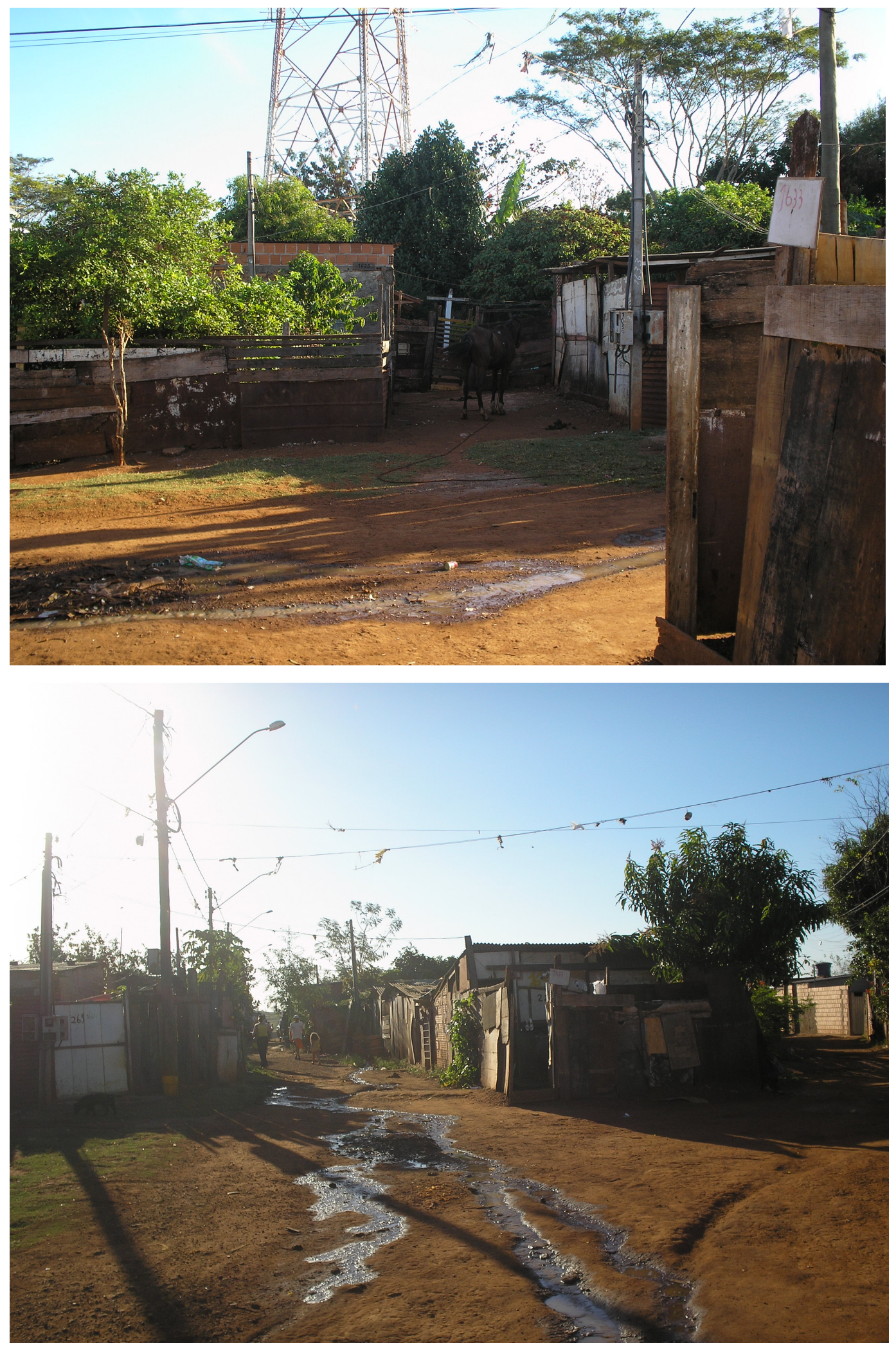


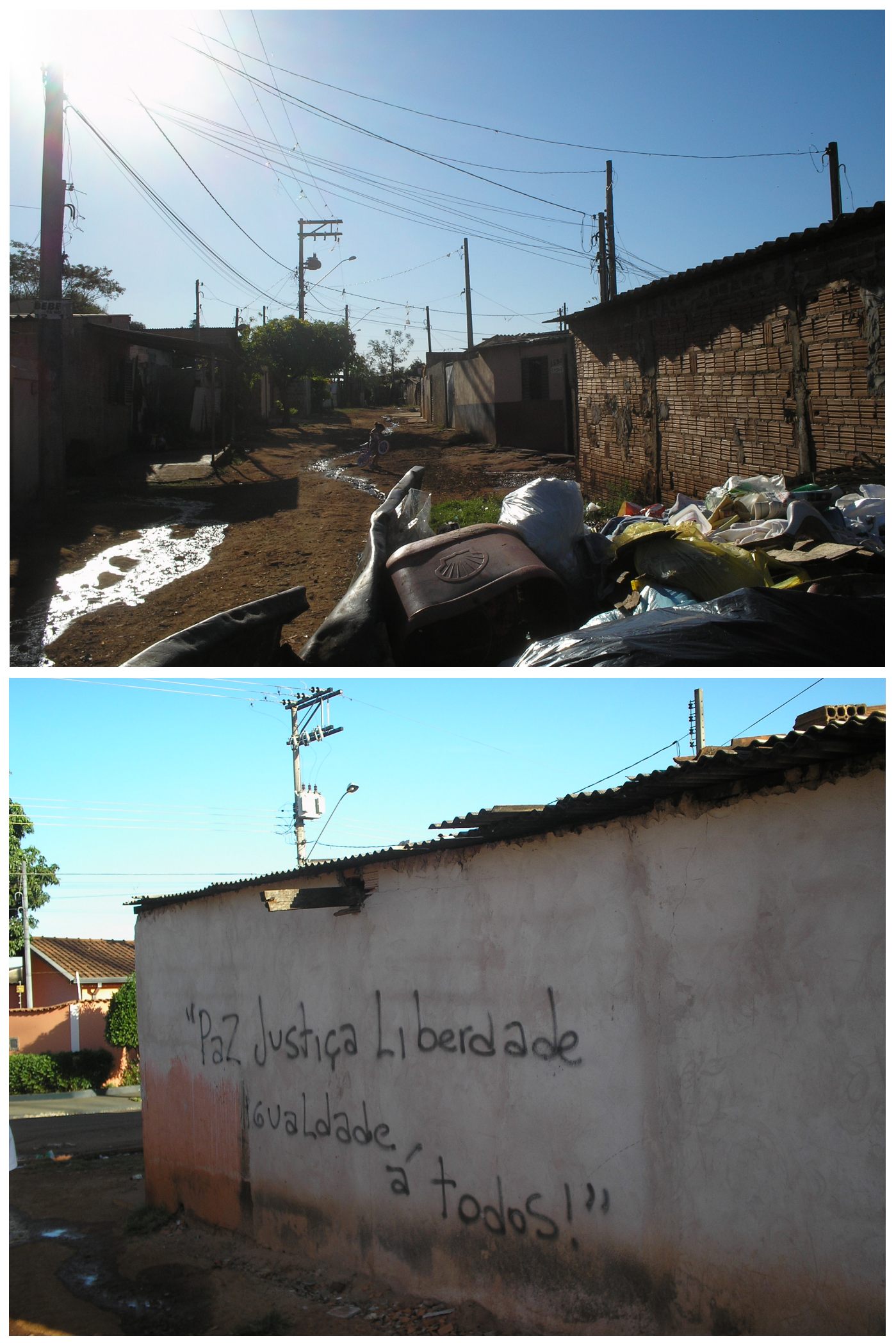



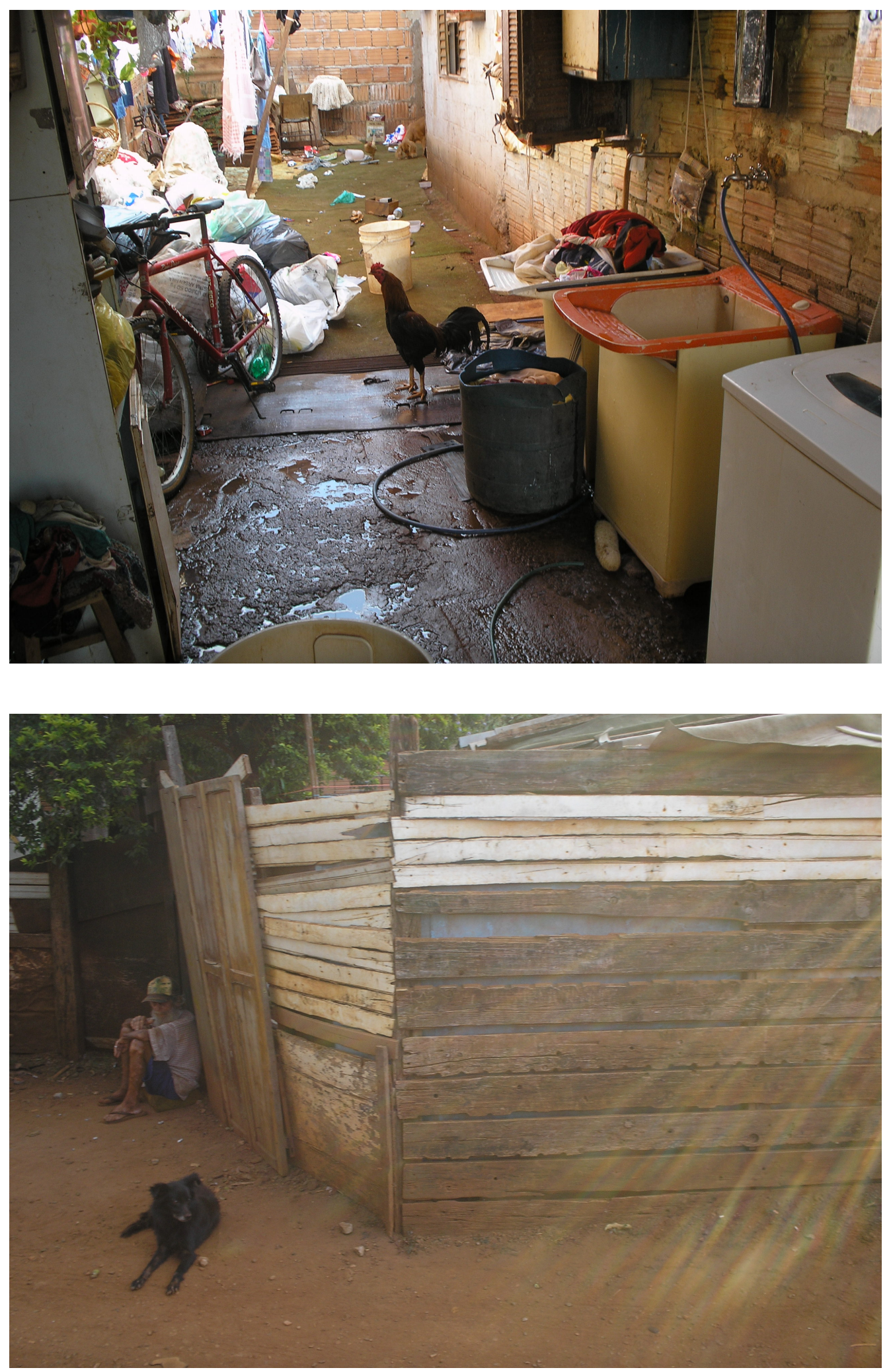


\section{A área do bairro antigo}
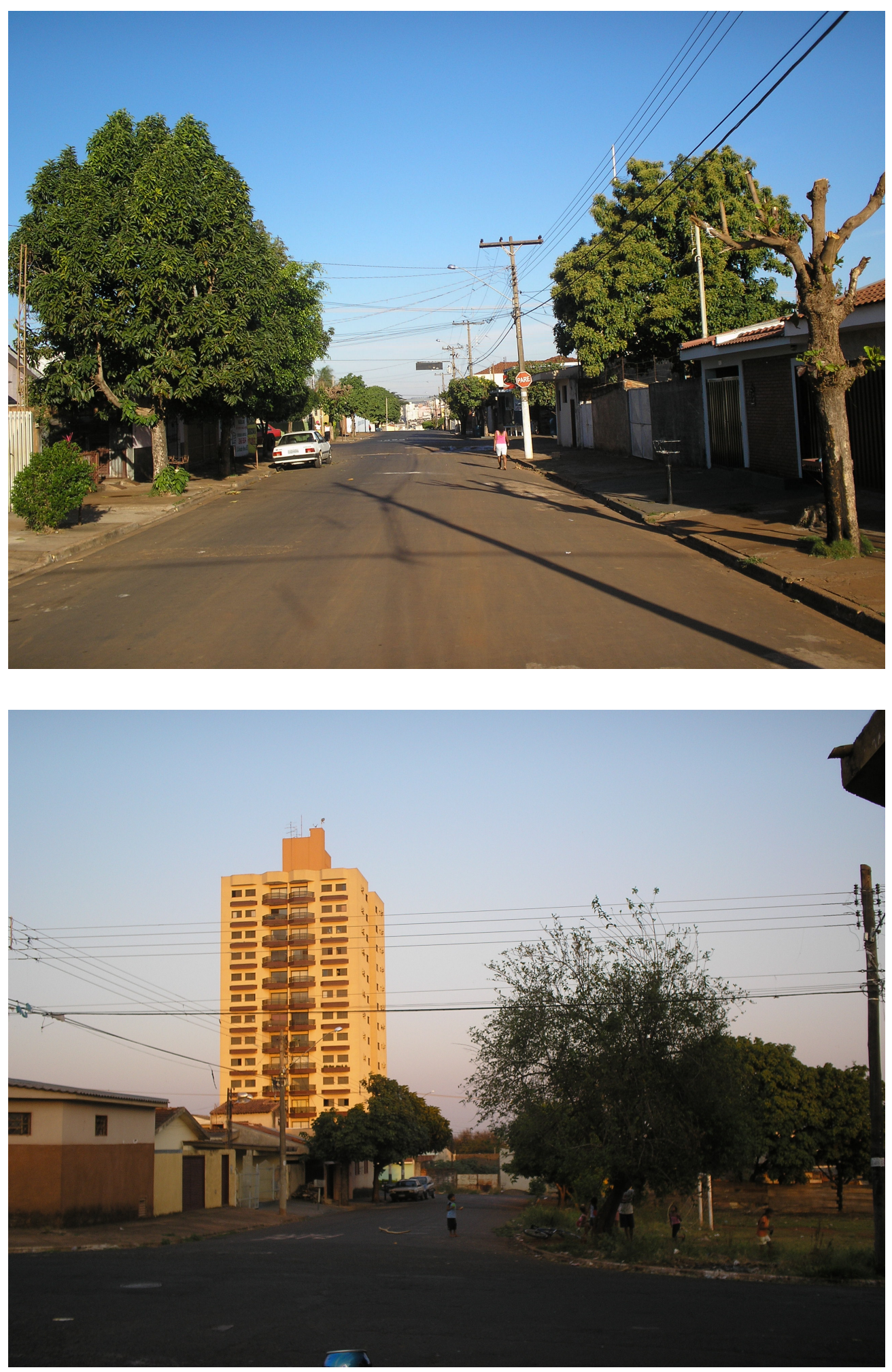

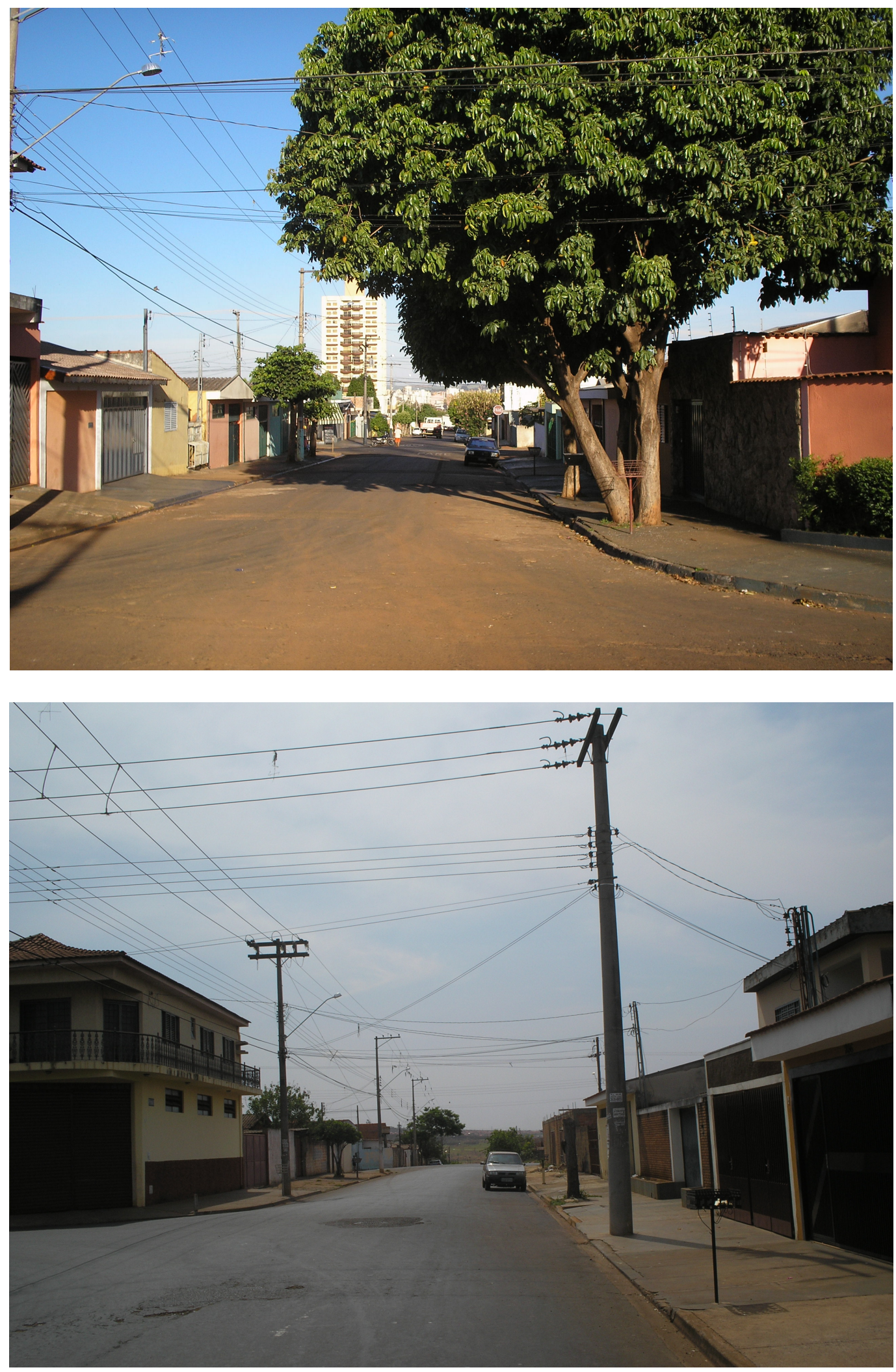
$A$ área do bairro de casas $C O H A B$
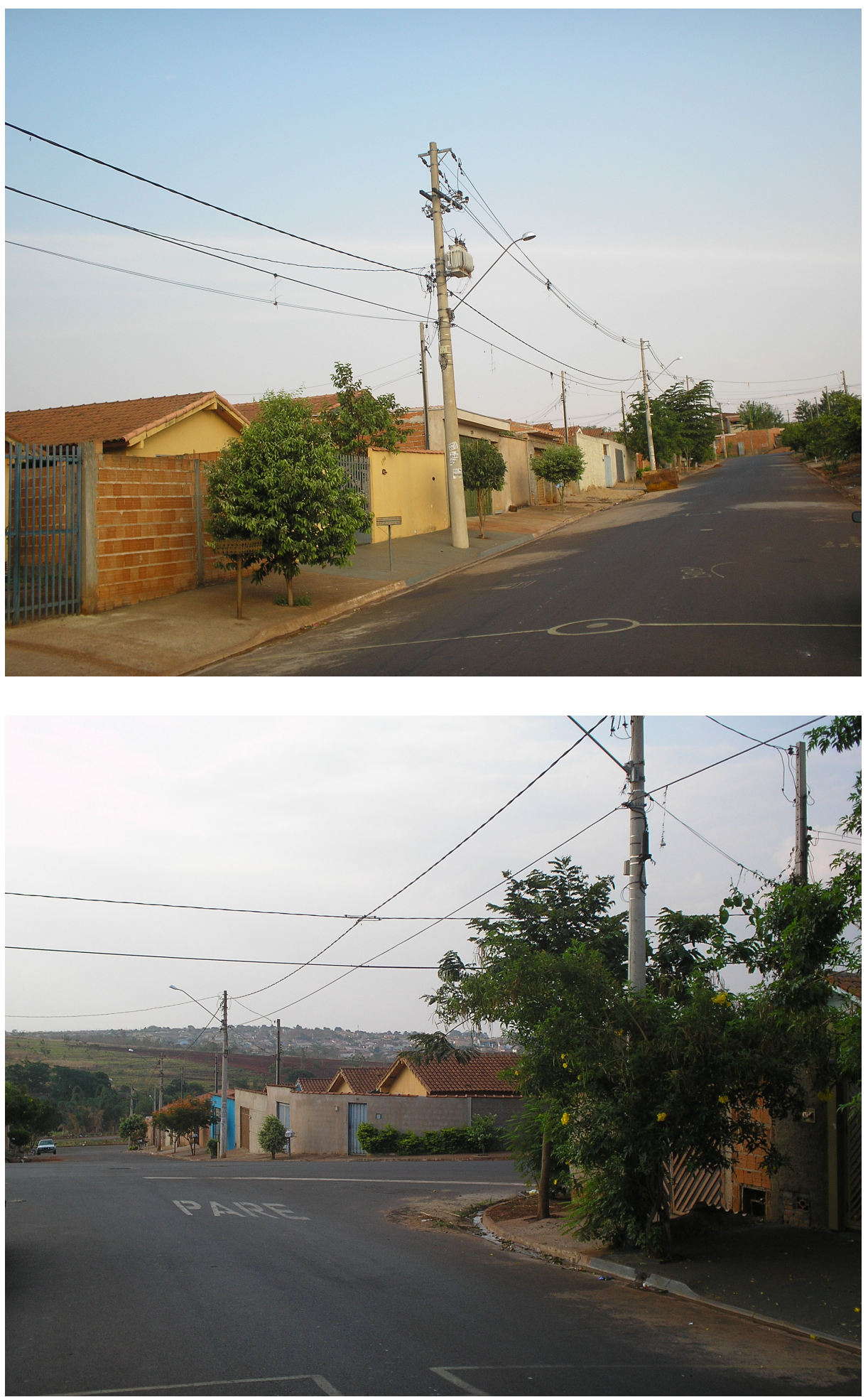

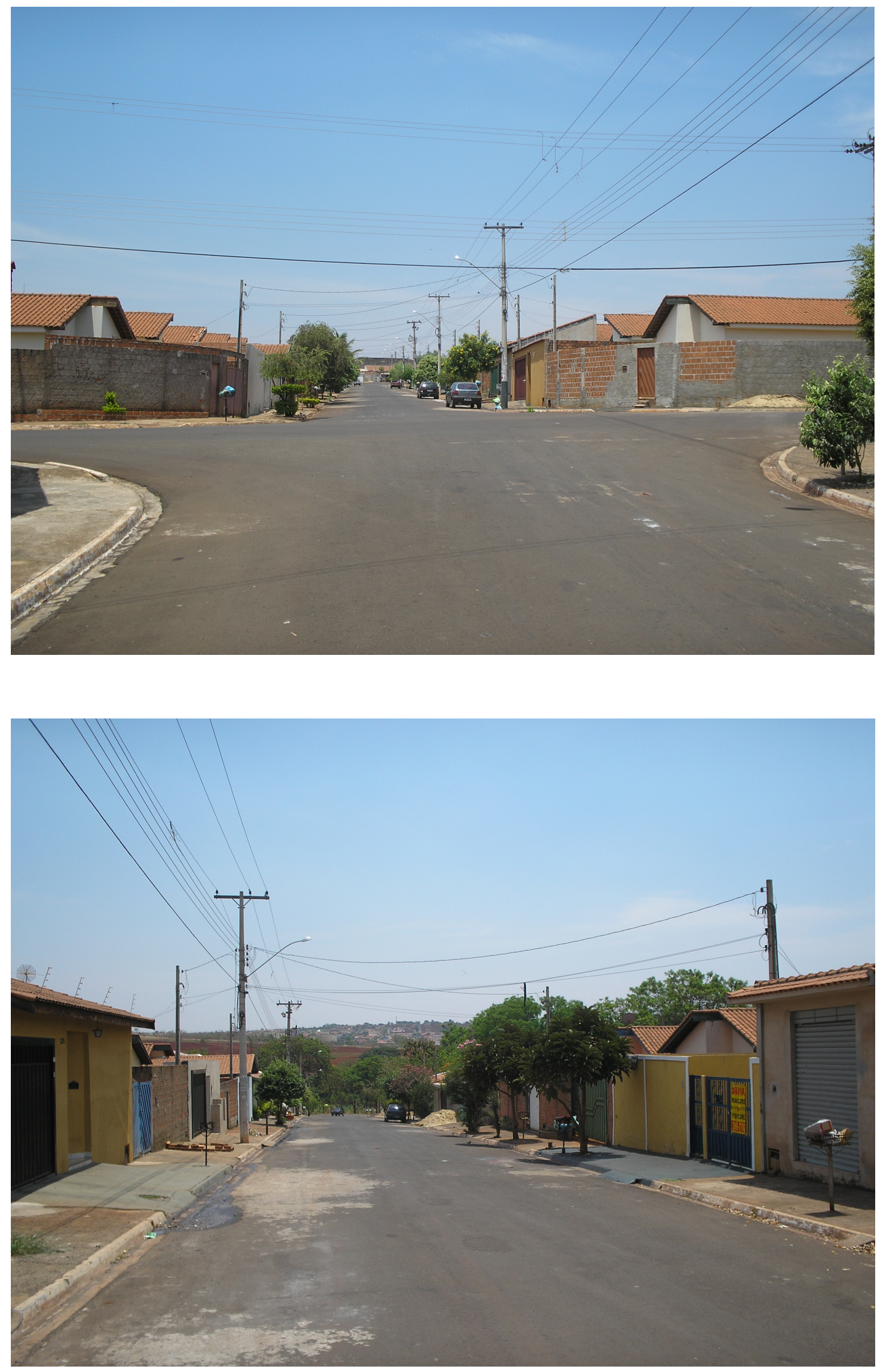

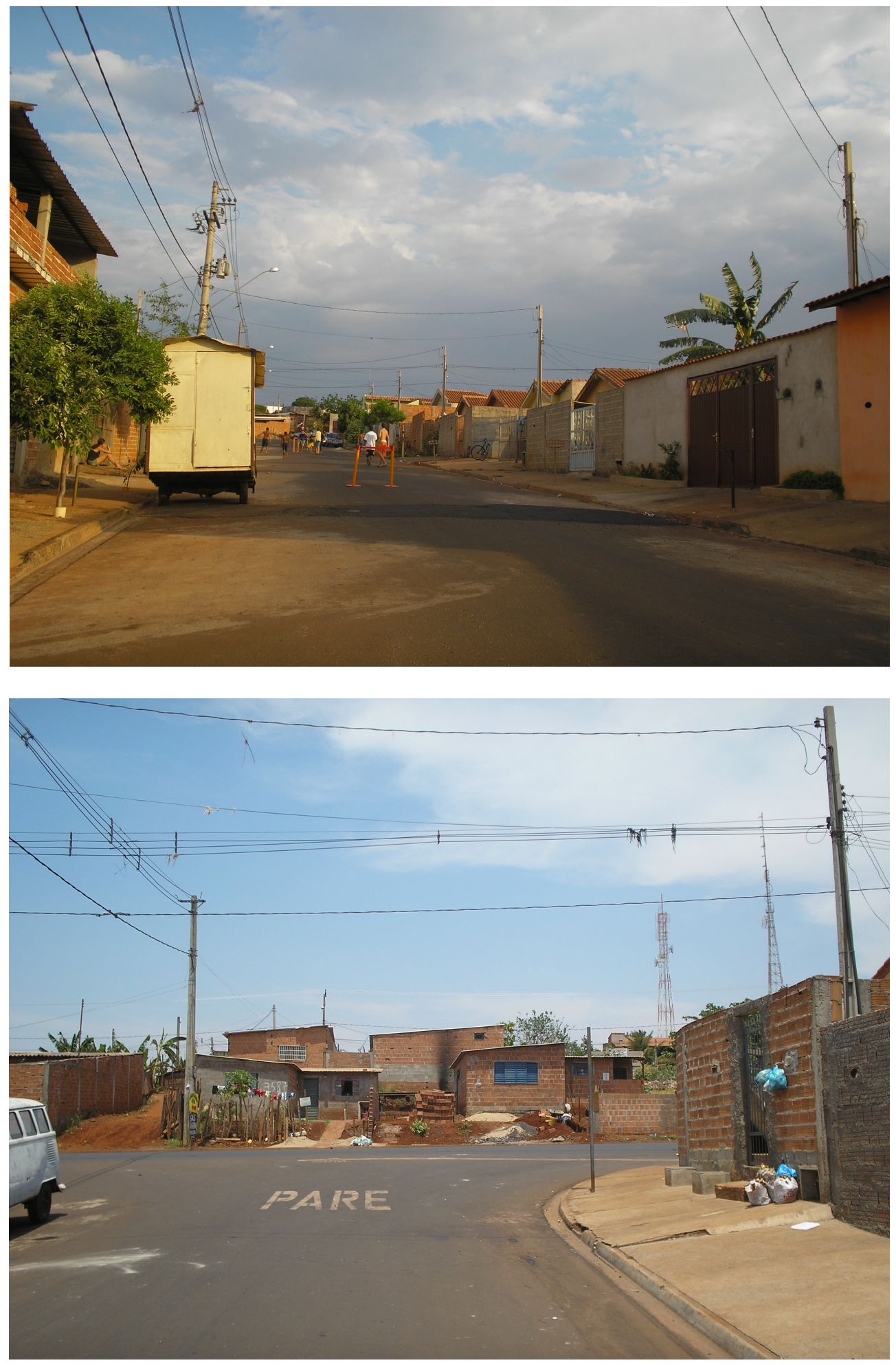
A área do bairro de casas luxosas
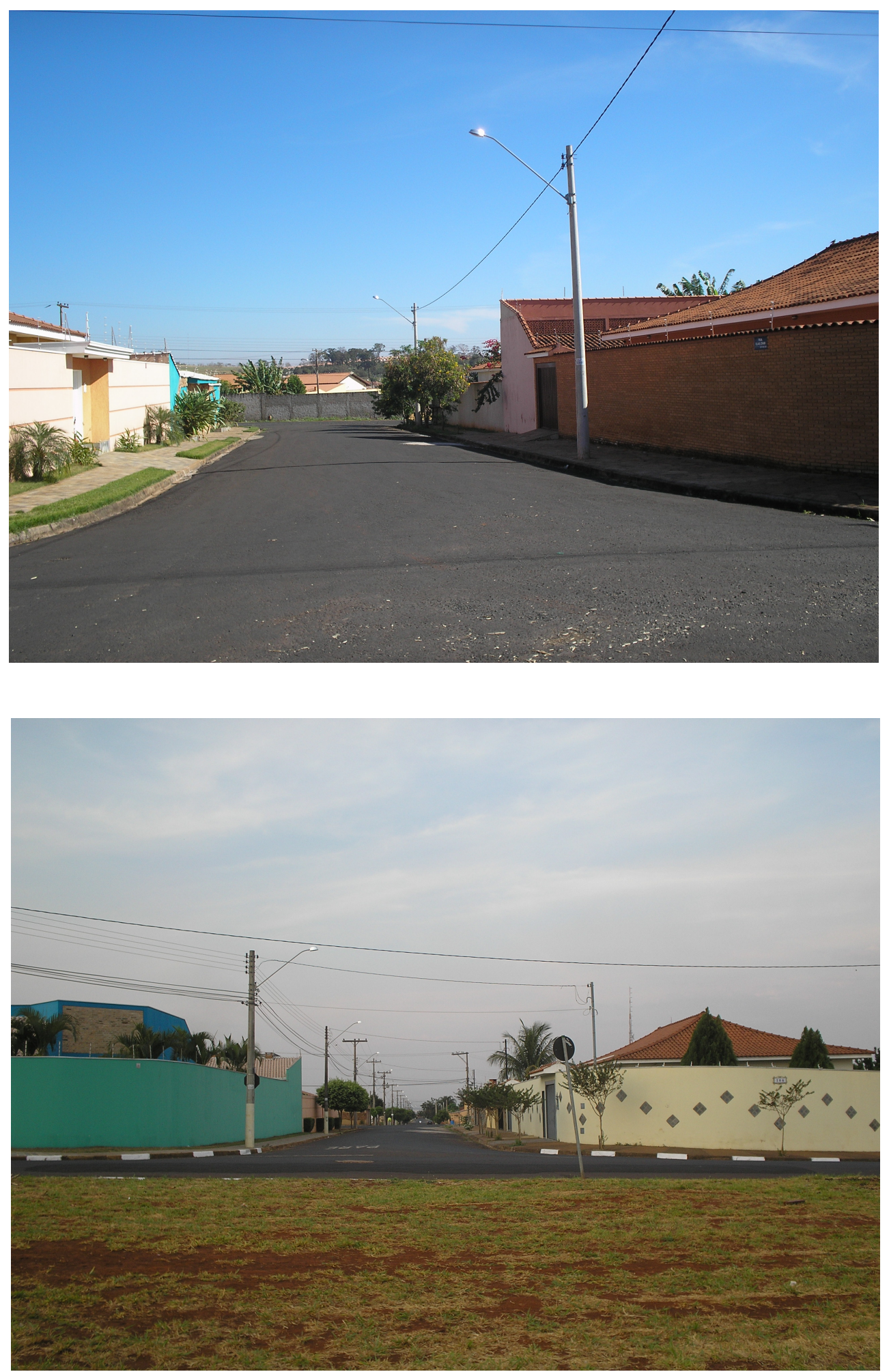

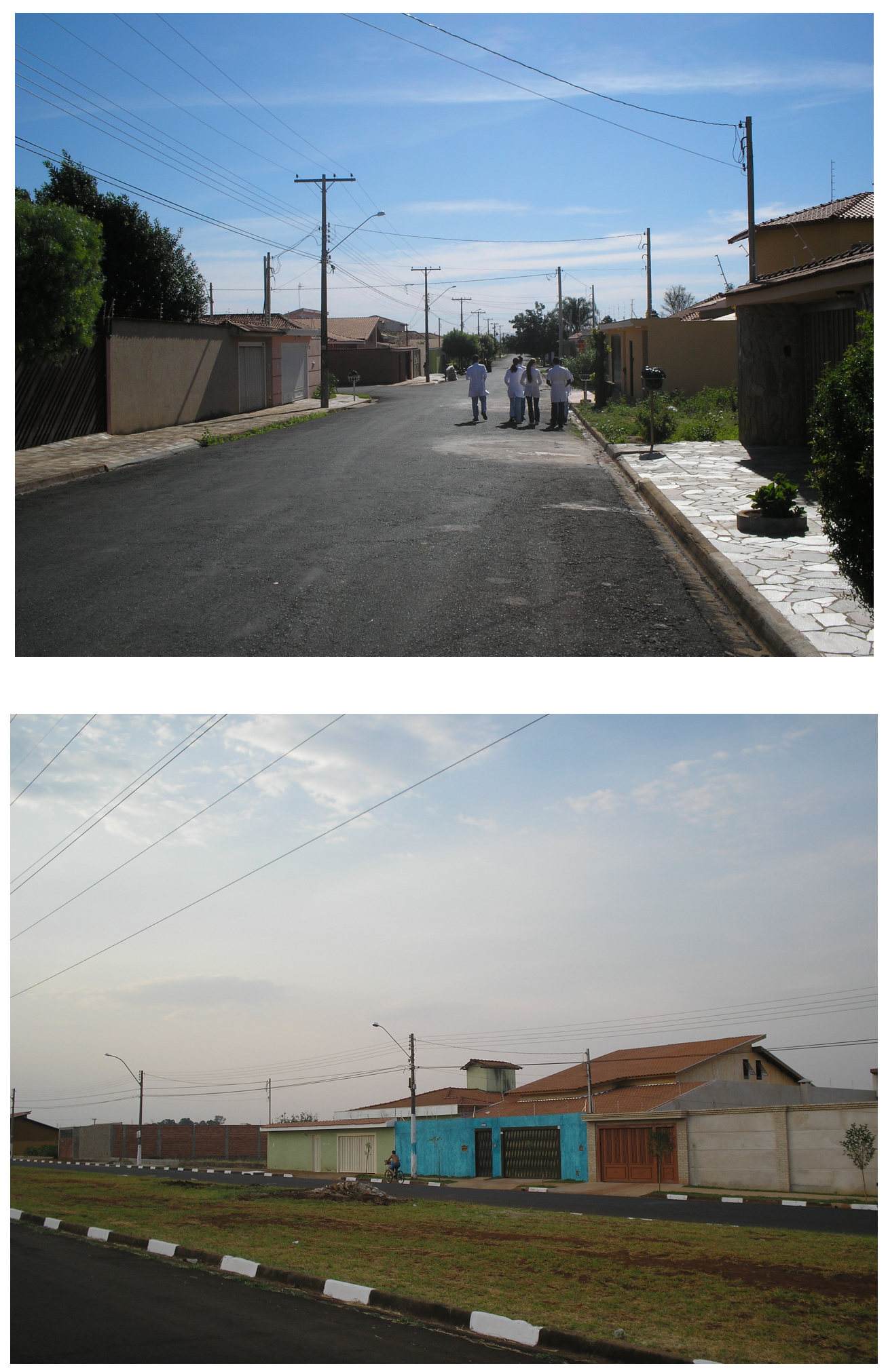


\subsubsection{Os espaços dos homens: das bordas ao centro do bairro antigo}

As divisas entre as partes que pesquisei nem sempre são divisas de bairros, são divisões simbólicas, destacando distinções. Neste contexto, começo como a rua que divide a favela do bairro antigo. Foi convivendo nesse pedaço conflituoso, neste lugar de fronteira, que pude encontrar alguns de meus entrevistados, como Marcos, um homem de 52 anos, casado, morador da parte da rua para o lado dos moradores mais antigos, dizendo-me inicialmente que não tomava remédios para os nervos e nem para depressão, utilizando somente os para o diabetes, e depois de me mostrar os medicamentos vi o ansiolítico diazepam e o antidepressivo amitriptilina. Marcos, um dos 14 filhos de uma mulher nascida em Minas Gerais de origem rural, tendo hoje vivos somente 6 irmãos, disse-me que sempre trabalhou muito, principalmente depois da separação do pai de sua mãe, que deixou ele e seus irmãos ainda novos: "meu primeiro serviço foi plantar grama, jardineiro, depois ferro velho, depois mecânico". O dar conta do trabalho foi a justificava central para consumir os medicamentos psicoativos, ora relacionada a seu passado mais longe: "Tem problema de saúde, família, tem muito coisa errada, sempre tem problema, família, tem coisa errada e a gente vai tentar ajuizar. A minha família, a gente vai ficando sozinho, o meu irmão queria só farra, a minha mãe era doente, o meu pai já tinha separado dela, eu tive de manter a casa (...). O meu pai judiava muito da minha mãe, batia na minha mãe, aquilo foi ficando na minha cabeça e ai a gente teve que trabalhar, trabalhar..."; ora de um passado mais recente: "Ah, trabalhar muito, muitos problema, pra começar a friagem, é friagem, pegar um motor quente, a profissão de mecânica é problema, você pega um pepino forte, tem que resolver, sabe? A gente vai esquentando a cabeça.". 
Os medicamentos são relacionados com a dor de cabeça: "o remédio se eu não tomar complica (...) dá muita dor de cabeça”, servindo para controlar o sono e não ficar deprimido à noite, não dormindo direito. A necessidade de trabalhar revelou significado dado à relação entre ficar em casa e no trabalho. Quando perguntei sobre os vizinhos da favela, disse: "me dou bem com os vizinhos da favela, eles gostam de mim, é tranqüilo, não me encrenquei com ninguém, mora aqui a mais de 20 anos (...) quando vim pra cá era cana (...) teve a guerra com o pessoal dali, uma guerra (...), se não ficasse dentro de casa, morria”. Acrescenta que tem "tem um pessoalzinho aí (na favela) (...) é uma confusão danada, mas tem muita família boa”, e reclama das pessoas que vendem drogas na favela, dizendo que são alguns que querem dinheiro fácil, não querem trabalhar, mas "é todo mundo nos seus cantinhos", não incomodando ninguém.

Marcos me disse que ter saúde é trabalhar, é promover os movimentos ordenados do corpo, que sua condição de afastado do trabalho lhe deixa nervoso, mas que deseja se aposentar logo. Os medicamentos psicoativos são avaliados nesse sentido, produzir efeitos para a sua nova ordenação, levando o ambiente que vive a ser um regulador dos efeitos dos medicamentos: "às vezes peço pra trocar o remédio, quando não tá fazendo efeito”. Marcos, morando com sua esposa, uma filha e neto, dizendo que o pai de seu neto era nordestino, "veio e deixou a bomba na minha mão".

Foram realizadas duas entrevistas com Marcos, a primeira, por não estar achando o endereço, o agente comunitário me levou a sua casa, ouvindo parte da entrevista. Não cheguei a entrar em sua casa, ficando somente na garagem. Em frente a sua casa tinha um bar que freqüentei algumas vezes, era um bar simples, com uma mesa de bilhar, e ao lado, algumas mulheres ficavam sentadas em suas cadeiras "vendo o movimento". Foi num desse dias que encontrei o Marcos bebendo uma cerveja, a hora que ele me viu olhou-me muito assustado, ficando desconcertado, percebi que minha presença o reprimia, demorou um bom tempo para ele retornar a pegar o seu copo e levá-lo a boca. Assim, pode-se refletir sobre o papel dos serviços de saúde como repressores, como vigilantes dos comportamentos, como 
controladores do lazer. Desse modo, os agentes comunitários de saúde, ao morarem na comunidade em que atuam, podem ter um papel de policiamento, coagindo os moradores a terem determinados comportamentos considerados ideais, como uma imposição do "mundo do asfalto" ao mundo "favelado", coagindo a população a seguirem determinados padrões aceitos, colaborando para o desenvolvimento de discriminações e ações autoritárias dos serviços de saúde, afastando de um diálogo em que ambos tenham voz ativa. Os serviços de saúde estariam, ao produzirem uma norma, colaborando para evitar questionamentos representados por uma anomia, o que socialmente não está correndo bem pelas imposições de determinados grupos sociais frente a outros, o que se torna visível como anormal para o grupo social que está relativamente em posição vantajosa (ELIAS, SCOTSON, 2000). As pessoas “de fora", dos outros Estados que ali se localizavam em busca de melhores condições de vida, como os moradores da favela, ao destacarem uma distância sociocultural em relação aos moradores antigos, estariam sendo vistos como anômicos. Além disso, pode-se acrescentar o fato de que esta relação de poder (norma) e resistência (anomia) pode contribuir para o consumo de medicamentos ansiolíticos e depressivos devido à desigualdade social gerada.

Nessa perspectiva, a condição de homem trabalhador é tão importante para Marcos, que ficar em casa estaria fugindo dos padrões estabelecidos. Morar nessa rua é estar numa posição de julgar o outro lado, o da favela, e ser julgado pelo lado dos moradores antigos. Nesse sentido, morar do lado da rua da parte antiga é muito importante para o Marcos, pois na outra parte está mais distante do que é considerado normal, é estar sujeito a ganhar o dinheiro fácil, sem trabalho, mesmo tendo algumas famílias que são consideradas "boas".

A (auto)exigência do cumprimento dos papéis sociais exigidos pode também ser analisada sob uma perspectiva de gênero. Discuto gênero a partir de BUTLER (2003, p. 29) ao dizer que gênero se apresenta como "fenômeno inconstante e contextual, o gênero não denota um ser substantivo, mas um ponto relativo de convergências entre conjuntos específicos de relações, cultural e historicamente 
convergentes". O conceito de gênero nem sempre é distinguido, pois é construído do, no, pelo e para o corpo. O gênero exige uma performance socialmente aceita.

Nessa perspectiva, BUTLER (2003) mostra como o conceito de gênero esteve marcado pela heterossexualidade compulsória, que coloca o pólo homem/mulher como único viável que procura descrever tipos ideais de homens e mulheres. Além disso, segundo a autora, a dicotomia entre homens e mulheres proposta através do conceito de heterossexualidade, ao ser falsa, os papéis podem ser invertidos, os sexos passam também a serem produtos de performances, isto é, homens e mulheres não possuem lugares fixos, podem assumir diferentes posições, isto é, um pode ocupar os lugares que são previamente definidos como do outro. Para BUTLER (2003), o fato de o sexo ser colocado como parte da natureza, parte pré-discursiva, em que não é construído também pela cultura, o coloca como divisor e promove interpretações que levam a conceber a matriz heterossexual como inquestionável e imutável. O gênero ideal, segundo BUTLER (2003), não deixa de ser uma ficção, projeto impossível de ser alcançado como condição natural e fixa, e sim como fabricação, performance, representando um ideal determinado sócio-historicamente imbricado por relações de poder (BUTLER, 2003; LOURO, 2004).

A predeterminação de um comportamento pode significar a formação de habitus, como explica BOURDIEU (1999) através de seu estudo sobre a sociedade Kabila ao observar a existência de naturalização de que o espaço doméstico é reservado à mulher e o público e dos negócios, aos homens, o que ele chamou de "dominação masculina" ao verificar que esta definição de papéis é formada como habitus, e que ocorre a (auto)exigência para sua permanência. Nesse sentido, as exigências de comportamentos estão interligadas por toda uma coletividade, definindo espaços em que homens e mulheres devem ocupar dentro da estrutura social. Assim, os medicamentos antidepressivos e ansiolíticos (psicoativos) irão colaborar para a manutenção de habitus, para fixar papéis e contribuir para definir socialmente gênero.

Do mesmo modo que Marcos, Ernani (casado, com 46 anos, mora com sua esposa e quatro filhos) me disse tomar os medicamentos psicoativos devido ao seu 
trabalho de vigilante e segurança, exclamando que um homem sem trabalho perde a moral, a vontade de sair de casa. Fazia dois anos que já usava os medicamentos psicoativos, sendo também afastado do trabalho, disse que não estava dormindo à noite, tendo muito preocupação com sua situação, que se sentia impotente frente aos filhos. No dia da entrevista fazia dois meses que sua mãe havia falecido: "pra mim eu sei que minha mãe faleceu, você tá vendo que é um pedaço seu e você não pode fazer nada”. Acreditava que sua condição de doente iria provocar sua demissão, colaborando para que também tivesse medo de ficar sadio, pois poderia deixá-lo desempregado. Como revelou Ernani, ele vive numa condição de ser julgado a qualquer momento, independente do que fizer:

"Eu tô afastado eu tô quase com 2 anos e a hora que eu voltar eu vou trabalhar, eu acho, 3 meses e vão mandar embora. Eles já me mandaram embora, só que eu não assinei. Eu não sei se foi por isso... ou se eles achou que eu tava doente... não sei... é difícil entender... a única coisa que eu sei é que o meu chefe não gosta de mim. Aconteceu um incidente, umas coisas que você não entende. Tem uma porta giratória, assim, se o cara chega e te aponta o revolver e você abre a porta você é culpado, eles te mandam embora, se você não abrir e o cara atira e mata alguém ou mata a gente próprio mesmo, também é culpado (...). Eu penso, assim, em acabar com minha vida, mas a minha mulher fala 'oh você tem que ser perseverante, perseverança, tem que seguir em frente'. Eu sinto que eu não tenho mais valor nenhum, entendeu, pra mim eu não valo nada, sabe, tá ou não tá pra mim tanto faz. Então eu falo assim: 'eu não posso trabalhar pra dar coisa pra eles (filhos)', né, então fica na cabeça da gente”.

A condição de Ernani de "sem-trabalho" possibilita uma redefinição de sua pessoa dentro da casa, de sua família. A casa de Ernani, que fica em frente à favela, é cercada por paredes, sua socialização parede ser abalada por sua condição de "semtrabalho", retendo-se em sua própria casa. Ter um emprego e uma casa significa definir um estilo de vida e capacidade para o consumo, porém, os grupos populares não conseguem produzir um consumo que ultrapasse as despesas da casa, da sobrevivência da família, gerando constante sentimento de insatisfação e insuficiência, marcada pelo medo do desemprego, do distanciamento do que é considerado normal e de situações que poderiam levar a um maior gasto financeiro como a ocorrência de doenças, como ocorreu com Ernani. 
Nessa perspectiva, em pesquisa realizada em subúrbios de uma cidade francesa, AVENEL (2000, p. 44) revela que as exigências para ampliar o consumo da família podem ser vistas através dos filhos adolescentes, contudo, quando o desemprego ocorre, levam a família a se isolar do restante do bairro e a vida se retrai no ambiente privado da casa, a "família fechada sobre si mesma passa a ser a causa e a conseqüência das escassas possibilidades de lidar com o mundo social: ela se torna ambígua (...). A infelicidade privada assinala então a infelicidade absoluta, o fracasso mais completo - um fracasso vivido como inteiramente pessoal". A casa como proteção e conforto se torna uma espécie de jaula para seus moradores em situações econômicas precárias, produzindo um ambiente envolto por desânimos, tristezas. A autonomia dos indivíduos e a sua posição como consumidor quando não conseguidas levam a condição de se culpar, responsabilizar-se, mostrando que as condições econômicas levam a julgar e a se julgar, definindo sua posição na estrutura social:

"Não há inimigos. No máximo, o próprio ator se torna seu próprio 'adversário' e o sentimento de estar prisioneiro das quatro paredes de uma habitação se transforma no sentimento de não mais ser ele mesmo, como se as 'grades' da prisão se instalasse no interior mesmo do indivíduo. O que é ainda mais importante: esses moradores se vêem pelos olhos dos outros, pelos olhos das classes médias, desses atores que se dizem integrados - ou seja, através das categorias do estigma e do fracasso, que eles acabam por interiorizar. A relação consigo mesmo é determinada pela imagem negativa enviada pelas classes médias" (AVENEL, 2000, p.46)

A construção de uma casa, que é aqui também vista como parte de um projeto histórico-social, está inserida na formação de uma sociedade individualista, levando a conflitos e a transformações na família, marcada pelas dificuldades econômicas e a exigência de autonomia e independência de seus componentes (SINGLY, 2000). Como exemplo, a pessoa antes socializada na favela vê-se diante de paredes e janelas, o perigo que fora freqüentemente representado por ele repentinamente se inverte, o mundo fora de sua casa agora é o perigo, distinto de seu passado. Os laços de solidariedade são transformados, antes preservados na família e na parentela, ou pelos moradores da favela, ao impedirem uma comunicação coletiva tête-à-tête são enfraquecidos. Na própria família ocorre a existência de um conflito entre um mundo individualista e o familiar, a casa representando divisões, e antes na favela a vida de 
cada indivíduo é pública dentro de suas casas, com cômodos pouco divididos. De acordo com AVENEL (2000, p. 34):

"As camadas populares do subúrbio vivem o conflito dessa experiência dual entre as condições de vida e as aspirações culturais. A família está, precisamente, no coração dessa situação paradoxal e carrega tais contradições. Ela se desenha, assim, de forma ambígua entre dois princípios de orientação propostos. De um lado, a esfera familiar privada é um ponto de apoio essencial que preserva uma imagem aceitável e o lugar no qual se pode ainda exercer algum poder. Mas, de outro, ela marca também uma linha de ruptura na qual se está o tempo todo ameaçado de fracassar. Desse modo, a família torna-se ambígua: ela não é somente 'desafiliação', mas também reafiliação, ponto de apoio e linha de ruptura, objeto de proteção e ainda o lugar de reclusão".

O processo de individualização que ocorre através da moradia é também marcado por heterogeneidade, revelando sua diferenciação de acordo com o contexto envolvido, desenvolvendo projetos e escolhas (VELHO 1997). Nesse contexto, este autor mostra como a ascensão à classe média no Rio de Janeiro está em constante comunicação e conflito com o passado dos indivíduos envolvidos, seja com a família ou com o bairro de origem, particularizando o individualismo por interagir estilos de vida tanto de sua origem sociocultural com dificuldades econômicas quanto à nova capacidade de consumo. A família é vista como lugar de felicidade, encontro de sonhos, de "ter sua casa", porém é também uma busca por concluir um processo de individualização, separar-se do outro, e ter um lar representa os primeiros passos para este encontro. Morar nas casas COHAB e na parte antiga do bairro pode significar começo de um novo caminho, na busca de melhores condições econômicas, gerando ansiedades, enquanto na favela a moradia significa um fracasso, tristeza. Com a casa, o mundo de lá de fora já não tão mais o do vizinho, é um mundo que chega via satélite, televisionado, os diálogos do dia-a-dia serão pautados nas imagens transmitidas pela televisão, durante a noite ao passar pelos bairros as vozes de seus moradores são silenciadas em função dos horários "nobres", das telenovelas.

As condições econômicas precárias, ao interferirem na estrutura da família, promovem conflitos, sendo estas a justificativa para o consumo de medicamentos 
psicoativos, o que pode estar mais agravante em pessoas que possuem maiores possibilidades de perder o emprego. Compreendendo que a falta de emprego e a licença médica podem reter as pessoas em seus ambientes domésticos, o ficar em casa pode sugerir que o consumo de medicamentos psicoativos seja propiciado no ambiente doméstico devido aos conflitos existentes nesse espaço.

O trabalho de vigilante dos homens foi destacado por outros entrevistados e algumas pessoas que encontrei que me disseram que a profissão "mexia com os nervos", alguns utilizando ou ansiolítico, ou antidepressivo. Que o trabalho era motivo de muita discussão em casa, revelando um ódio reprimido de seus empregadores. As dificuldades relacionadas a este trabalho e ao consumo de medicamentos psicoativos foram destacadas devido à falta de um horário fixo, envolvido em um processo de desgaste mental, como me disse um morador da rua que divide a favela dos moradores antigos: "a gente é tipo uma laranja, espreme até ficar o bagaço, depois joga fora”.

Adentrando um pouco a parte dos moradores antigos, entrevistei Dagoberto, uma rapaz de 30 anos, casado, segurança e vigilante, que me diz os motivos do consumo dos medicamentos psicoativos:

"problema emocional mesmo, entendeu, foi que devido ao trabalho, o excesso de trabalho, trabalho demais e dormia pouco, isso foi causando a dependência do remédio pra dormir, atacou o sistema nervoso (...) o médico falou em controle compulsivo, uma coisa mais ou menos assim, que eu devido ao fato de eu não dormir, trabalhava dia e noite, foi causando transtorno muito grande, entendeu, um estado nervoso, chegou o ponto que eu comecei a sentir medo de sair na rua, um pânico (...), ai foi onde entrou com o remédio pra mim dormir, ai depois entrou com a fluoxetina, né, isso me causou transtorno também, a pressão começou a subir, ai eu comecei a tomar pra pressão, ai foi indo, foi indo, comecei a dormir, comecei a descansar, sacrifiquei um serviço fiquei com um só, comecei a descansar, aí voltei ao normal. A causa de usar esse remédio forte, o diazepam e a fluoxetina, foi pra terminar um pouco o pânico, eu não tava podendo dirigir mais. Eu trabalhava como segurança e de dia eu vazia bico. É uma área de risco então a gente tem que enfrentar tudo quanto é tipo de pessoa, era uma área aberta, movimentada, então tinha que lidar com pessoa perigosa, não perigosa, então ficava trabalhando tenso demais, então chegou a forma que você não tinha horário fixo, então uma hora tava de noite, uma hora tava de dia, tinha que dobrar de dia, então atrapalhou tudo, alimentação, horário de dormir, o sistema nervoso porque você trabalha com a cabeça o dia todo, é 
recebendo ameaça, então aquilo causou um pânico (...). Foi em 2001 que foi a primeira vez que aconteceu, não foi por causa do excesso de trabalho, foi uma perca muito grande financeiramente que tive, que causou transtorno, preocupação, fiquei desempregado mais de um ano, então, preocupação, conta pra pagar, criança pequena pra cuidar, isso foi criando transtorno."

Dagoberto revelou que já havia interrompido o consumo dos medicamentos "por conta própria", por medo de ficar dependente e por sentir melhora dos sintomas porque já conseguia sair de sua casa "mais tranqüilo", por conseguir dirigir e ir visitar sua mãe. Os medicamentos são vistos como a solução escolhida para o tratamento, visto que a relação trabalho com a vida social não permite outros tipos de tratamentos: "o doutor marcou sessões pra mim no HC, só que eu não compareci nenhuma delas porque eu não achei viável, eu já tinha melhorado, não achei viável falar. Agora eu trabalho, peguei estrada".

A casa, ao ser vista como lugar de descanso para Dagoberto, lugar em que não mais precisa estar vigilante, deve permitir delimitação de comportamentos e ações diferentes que são definidos ou construídos no decorrer de sua vida, impondo normas.

Ficar doente mostra-se não somente como uma ameaça às desordens do corpo, significa uma desordem familiar, seria como se a família simbolicamente adoecesse. Além de o ficar doente estar relacionado a um sentido físico, do corpo que deve estar pronto para o trabalho, possui uma conotação moral (DUARTE, 1986). A relação com sua vida social pode ser levada para os consultórios médicos, que revelam um distanciamento das necessidades sociais do paciente, como as ameaças de perder o emprego, de sentir qualquer sintoma que leve o empregador a suspeitar de um futuro prejuízo financeiro, o corpo se estende a seus limites de produção, ficar doente não somente pode significar uma ameaça aos rendimentos quando se faz os "bicos", os trabalho precarizado, sem carteira assinada, as eventualidades de trabalho além do emprego considerado fixo:

"Na época eu fiquei 15 dias afastado, inclusive o segundo médico do trabalho achou que deveria afastar mais, até mais, e que quem podia me afastar mais seria o meu médico, dai eu vim no núcleo (saúde mental), eu não estava bem e na firma que eu estava trabalhando eu trabalhava sozinho trancado à noite, me dava uma tensão muito nervosa de ficar trancado lá 
dentro. O médico entrou em contato com outro médico, psiquiatra lá do HCe ele disse que não era necessário eu afastar e que seria até pior. Eu achei besteira do médico falar isso, porque a partir do momento que você tá com problema, o dever dele, do médico é te afastar, principalmente numa situação dessa, que o problema era o trabalho, inclusive ele não me afastou e eu acabei sendo mandado embora do serviço, na época, acabou que foi piorando a minha situação na época, dai eu fiquei quase um ano desempregado, e eles não tá nem aí, agora eu venho tratar com médico que sabia meu problema, me deu tarja preta pra beber, agora, chega na hora de me afastar do trabalho, ele não quis me afastar porque não era viável, então como é que um médico pode dar uma tarja preta pra você beber e dizer que não é necessário afastar, o médico do trabalhado já havia passado 15 dias, ai que aconteceu a firma ficou mediante os atestados que eles me deram e eu levei na firma, a firma me mandou embora e me acusaram que eu tava louco, entraram com recurso pedindo a minha demissão dizendo que eu tava louco e que eu era capaz de até matar uma pessoa lá. O local que eu trabalhava ficava pessoas lá depois que fechava, ficava pessoas sozinhas comigo lá dentro, até chegou a fazer a reunião com a diretoria e falar 'oh nós temos que mandar esse rapaz embora, que ele tá com problema mental e que a qualquer momento ele pode atacar algum de vocês e matar um de vocês' (...). Eu falei com o doutor, na época ele falou que não fez porque não achou viável, dizendo que eu ia piorar, eu falei que o meu problema é descansar, que 'eu sinto cansaço lá onde eu tô, cada dia eu tô cansando mais', aí perdi o trabalhado, ai vim e falei com o doutor, ai ele falou fazer o quê agora, você vai ter que arrumar outro serviço, foi essa resposta que ele me deu (...). Eu tava com uma semana que eu tava trabalhando na contabilidade (em outro trabalho), eles pediram informação lá (no emprego anterior), ai eles falaram que eu era louco, que tinha problema de cabeça, que era agressivo, que se precisassem de testemunha (...) ai o rapaz me dispensou e me disse que eu não era uma pessoa de confiança (...), então eu acabei apegando com Deus, (...), 'o remédio não vai adiantar só você que vai resolver essa situação' (...), sinceramente, depois eu até desanimei de ir ao médico, ali depois pelo fato depois disso do que aconteceu. Falei porque vir no médico, médico constata o seu problema e aí a hora que você precisa do médico, precisa do afastamento, ele diz que não pode te afastar, então porque eu vou, então você tem um problema, te dá um remédio pesado como foi no meu caso, te dei o remédio pra mim dormir, eu falei 'oh doutor como é que o senhor me dá um remédio pra dormir sendo que eu não tenho um horário certo lá, tem dia que eu tenho que dobrar, tem dia que eu vou noutro horário, tem dia que eu vou à noite, tem dia que eu tem que ir de dia, como é que eu vou tomar um remédio descontrolado desse jeito, então eu preciso de um afastamento pro senhor acompanhar o medicamento, fazer acompanhamento do medicamento, por isso do afastamento pra melhorar, dai não teve acordo não. É complicado... aquele senhor ali há muitos anos, em 2000 teve o mesmo problema que eu, ele tem fobia, sabe quantos anos faz que ele tá 
afastado, vai fazer 5 anos que tá afastado, então você veja bem, o médico achou por bem afastar ele. (...). Graças a Deus eu continuo na mesma profissão."

BRANT e MINAYO-GOMEZ (2008) observaram em uma empresa brasileira da região sudeste do Brasil que a relação entre insatisfações de trabalhadores sobre seus trabalhos, como intensificação das atividades, imposição de maiores rendimentos, falta de treinamento adequado ao uso de tecnologias e más condições para sua execução, ao levarem à condição de pessoa triste ocorria um processo de medicalização que desencadeava o diagnóstico médico de depressão, o qual é apoiado pela indústria farmacêutica ao banalizar o consumo de antidepressivos e a não demarcação em suas propagandas dos significados de tristezas e depressão. $O$ consumo de antidepressivos concentrou nas pessoas com menores salários. De acordo com os autores, o diagnóstico de depressão contribui aos trabalhadores como justificativa de seus comportamentos ao mesmo tempo em que exime as empresas de imposição de mudanças em sua estrutura e de promover melhores condições de trabalho. Desse modo, pode-se observar que os medicamentos, ao anularem conflitos entre empresa e trabalhadores, evitam mudanças e questionamentos, pois estes passam a ser medicalizados.

Essa busca para aproximar dos limites do corpo lembra as anotações de EHRENBERG (1995), as conseqüências por uma busca para alcançar os limites do corpo, a utopia de uma perfeição do corpo produtor. De acordo com EHRENBERG (1995), a sociedade disciplinar imposta numa condição de vigilância e punição deu lugar a um novo parâmetro: uma sociedade baseada no individualismo e na autoperfeição, não é mais o poder disciplinar que coage o individuo e sim este que se auto coage, auto-vigia para se tornar o mais perfeito possível, fazendo com que tenha uma alta e auto-exigência, esgotando-se até os seus limites. Desse modo, pode-se questionar o porquê de Dagoberto estar ainda trabalhando e estabelecendo seus limites. Sendo mais jovem do que Marcos e Ernani, Dagoberto resiste ao trabalho de vigilante e segurança. Além disso, deve-se lembrar que esses limites são também instituídos socialmente, sendo as pessoas que não adquirem um padrão aceito podem estar sujeitos a um afastamento do mercado de trabalho, seja como desempregado, 
seja devido a ser considerado doente. Como EHRENBERG (1995) diz, o individuo se mostra incerto, é um indivíduo de fronteira, que pede auxilio aos medicamentos para ampliar seus limites, extrair do corpo através da farmacologia os seus excessos, de uma responsabilidade de si. Assim, acrescento a questão relacionada ao gênero, a busca para proteger os limites do que se considera do homem, como mostrou os entrevistados homens acima, dar conta do trabalho, ir além do seu corpo, um culto à performance, ao desempenho máximo do corpo e, quando não alcançado, culpam-se, a doença ganha significado de culpa, efeito da sobrecarga não suportada. $O$ individuo, de acordo com EHRENBERG (1995) perde os parâmetros para se definir, seu olhar se volta para toda a sociedade, em um sentido de que os limites é que determinam as ações e não as ações que determinam os limites. Assim, o individuo se apresenta ansioso e deprimido nessa busca por superar, responsabilizando-se pelas imagens desejadas e não adquiridas, por se considerar insuficiente.

A esse respeito, CERTEAU (2005) diz sobre as possibilidades que o imaginar-fazer impõe-se ao poder-fazer à medida que o sonhar com outras realidades distantes do seu cotidiano impossibilita reações, ações, resistências: são estratégias de poder para manipular comportamentos. O que estou enfatizando é o papel dos medicamentos psicoativos na colaboração dessas estratégias, contribuindo para um conformismo, uma aceitação de posições na estrutura social, como as relativas à classe social e a gênero. Os medicamentos agem nas insatisfações, nos sonhos enganados, nas frustrações dos sonhos, ou mesmo na falta destes, ou quando não realizados, ou nas conseqüentes revoltas. Os medicamentos psicoativos aqui estudados reafirmam as imagens de um projeto não realizado, de uma vida não considerada plena em sua felicidade, em relação à aquisição da casa desejada, a um melhor emprego, aos filhos, maridos e esposas almejados. São imagens fantasiosas que correm a paisagem urbana, como o uso da publicidade, da propaganda, dos usos da mídia, favorecendo um desejo que está além das possibilidades reais, incentivando o consumo desmedido e com isso os limites do corpo, produzindo diferenças a partir do outro: diferenças entre bairros, entre classes sociais, entre modos de vestir, diferenças que produzem distinções, hierarquias. 
A felicidade pode ser aqui definida de acordo com o pensamento de COMTESPONVILLE (2001), uma aproximação à sabedoria, ao conhecimento, ao saber, o que está distante dos efeitos farmacológicos dos medicamentos psicoativos. De acordo com COMTE-SPONVILLE (2001), o que nos distancia da felicidade é a esperança, esta sendo marcada pela dúvida, pelo que não depende só de nós e pelos desejos daquilo que não conhecemos (e por isso a falta de esperança seria a sabedoria). Essa distância pode ser aqui ilustrada como alguns de meus exemplos encontrados no campo, algumas esperanças/esperar como: ser feliz em outra vida ou lugar, retorno do filho ou pais mortos, conhecer a mãe que já morreu, determinados comportamentos dos outros, não adoecer, melhores condições financeiras, os efeitos dos medicamentos psicoativos etc. Por isso, para COMTE-SPONVILLE (2001) a felicidade está no presente, pois a ela não se pode esperar, devendo para a sua ocorrência o querer, o agir sobre aquilo que podemos e sabemos e o que nos fazem alegres. A felicidade, ao ser vista como falta de esperança, pode desprender a pessoa daquilo que era esperado à medida que se adquire sabedoria, conhecimento sobre a condição de viver naquilo que faltava.

Compreendo que os medicamentos psicoativos agem na esperança não produzindo sabedoria, mas alienações, impossibilitando o querer e a vontade de agir em busca de conhecimento, promovendo enganações, falsas sabedorias ao encobrirem as esperanças, dúvidas. As esperanças resistem aos efeitos dos medicamentos, os tratamentos médicos confundem o que é felicidade ao supor que os medicamentos psicoativos irão suprir as faltas, o que não se tem na vida dos consumidores de medicamentos psicoativos. O movimentar e o juntar decorridos de acontecimentos passados se unem para formar um presente, uma projeção para a felicidade, para a realização de sonhos, de desejos. Os medicamentos psicoativos, ao evitarem esses dois verbos, não produzem felicidade, pois a esperança não foi anulada, o que se produziu foi a anulação do querer, as vontades. Produz-se conformismo, vazio sem saber, e não a falta de esperanças (sabedoria). Nesse sentido, os antidepressivos são erroneamente chamados de drogas da felicidade, simulando estados sem promover sabedoria. As pessoas entrevistadas relatam suas 
esperanças, seus desejos, mas muitos dizem que já não possuem vontades, forças, tornando-se insensíveis às esperanças. Acredito que os choros, os desabafos ocorridos nas consultas médicas são confundidos como sintomas de perturbações mentais, facilitando a prescrição de medicamentos psicoativos, confundindo estes estados como falta de felicidade. A felicidade se torna a partir do século XX uma norma enganadora através da massificação do consumo, uma felicidade industrializada, química e artificial (MORIN, 1967) que se impõe aos grupos populares de forma acrítica (incerteza devido à falta de previsão de melhoras aos consumidores de medicamentos psicoativos) e sem problematização, racionalizando o viver aos seus extremos e a homegeneização de um estilo único, numa única felicidade, como MORIN (1967, p.135-136, grifo do autor) diz: “A felicidade é, efetivamente, a religião do indivíduo moderno, tão ilusória quanto todas as religiões. Essa religião não tem padres, funciona industrialmente (...). Constituem o que, a vigor, podemos chamar de ideologia da cultura de massa, isto é, a ideologia da felicidade.".

Os grupos populares, ao não se encaixarem em modelos de felicidade, passam a ser medicados, o que sutilmente lhes diz para parar de querer, desejar, e por isso estes verbos são medicalizados. A esperança, ao estar relacionada com sintomas de doenças como depressão e ansiedade, torna-se uma via para o uso de medicamentos psicoativos. Pode-se aqui dizer que os sintomas são da esperança e não de doenças. Quanto mais distantes forem consideradas as realizações de suas esperanças, como o esperar serem felizes ou conhecer melhores condições de vida, mais susceptíveis se apresentarão ao consumo de medicamentos psicoativos.

Pode-se dizer que ocorre a produção de um caminho imaginário para uma felicidade idealizada, que só pode ser adquirida através da capacidade de consumir. Assim, um grupo social se torna modelo pelo que consome, levando a anulações de reações às condições desfavoráveis de um grupo social sobre o outro e o fortalecimento de subalternidade à medida que persiste uma busca por maior consumo, pela maior exigência de si, sendo freqüentemente ratificadas por frases 
como "eu também posso", isto é, subir os degraus de uma espécie de hierarquia de consumo.

A doença perde seu caráter biológico, do corpo que responde às agressões para vestir um novo parâmetro: ser insuficiente passa a significar doente e para permanecer aos limites do corpo sem que ocorra desgastes, o medicamento distancia da doença para aproximar das normas sociais impostas. Nesse sentido, a saúde está relacionada à performance, ao desempenho, aos movimentos contínuos do corpo. $\mathrm{E}$ cada minuto na vida cotidiana que é tido como não produtivo é reclamado, seja nas filas dos serviços de saúde, seja nos dias em que não encontrou um "bico" para realizar além de seu emprego diário. Desse modo, CANGUILHEM (2005) diz que os conceitos de saúde e doença não se restringem aos espaços científicos, são também conceitos populares, ao alcance de todos, sendo (re)significados de acordo com o ambiente envolvido:

“O corpo vivo é, então, este existente singular cuja saúde exprime a qualidade dos poderes que o constituem, visto que ele deve viver sob a imposição de tarefas, portanto em relação de exposição com um meio ambiente do qual, em primeiro lugar, ele não tem escolha. O corpo humano vivo é o conjunto dos poderes de um existente tendo capacidade de avaliar e de se representar a si mesmo esses poderes, seu exercício e seus limites." (CANGUILHEM, 2005, p. 41).

Como percebi, os homens que entrevistei já não se colocavam como uma simples máquina, com sua mecânica descrita com simplicidade como os primeiros motores de um carro. Uma máquina possui um limite pré-fixado, os homens aqui procuram constantemente ultrapassar seus limites, seus recordes. Agora, as comparações são mais tecnologizadas, são feitas em relação ao computar: "eu sou um computador, minha cabeça é um computador". O homem não é mais uma máquina predeterminada, é um orgânico manipulável, medicamentosamente moldado, performativo para buscar ideais passageiros, como os adquiridos através do uso dos medicamentos para modular a estética do corpo, tornando utopicamente o homem ou a mulher perfeita, o trabalhador mais produtivo de uma empresa, o dia mais rentável. CANGUILHEM (2005) diz que o corpo é modificado para singularizar suas capacidades e que a saúde não se deixa medir por meio de 
aparelhos, isto significando que a saúde se concretiza como produto social, levando um problema orgânico a representar mudanças no orçamento, um menor rendimento salarial, maiores chances de perder o emprego: “A saúde, como expressão do corpo produzido, é uma garantia vivida em duplo sentido: garantia contra o risco e audácia para corrê-lo. É o sentimento de uma capacidade de ultrapassar capacidades iniciais, capacidade de fazer com que o corpo faça o que ele parecia não prometer inicialmente" (CANGUILHEM, 2005, p. 43, grifo do autor). Nesse sentido, a experiência com os estados do corpo e com os efeitos dos medicamentos para produzir o corpo desejável corresponde aos parâmetros sociais e individuais. Ao sermos considerados insuficientes, nos apresentamos como doentes antes de vítimas dos excessos, levando a fazermos comparações com os momentos mais produtivos da vida, promovendo a busca para manter esse máximo. Ao corpo exige-se ritmo, constância, recordes, e quando não conseguidas as exigências, o corpo ganha caráter de doente, fazendo o envelhecimento ser tão temido quando este é acompanhado de perda de produtividade. Os estados do corpo, quando não representando um ideal, podem ser vistos como doença. Assim, a experiência com o corpo é importante para a auto-avaliação, o corpo improdutivo é visto como doente.

Este corpo não ideal, ao ser confundido como doente, para interpretá-lo encontro no conceito de experiência com a doença dado por RABELO e ALVES (2004) justificativa para interpretar a busca por sua (re)elaboração constante para aquisição de estados almejados. A experiência com o corpo não estaria somente produzindo uma ligação entre biológico e cultural, individual e social, objetividade e subjetividade (RABELO e ALVES, 2004), mas uma procura constante por aprendizado que somado ao passado reflete sobre o presente, buscando-se uma nova ordem para o corpo. De acordo com RABELO e ALVES (2004) a experiência com a doença é perpassada pela experiência do doente e das pessoas envolvidas:

"Isto significa dizer que a doença põe muitas vezes em xeque os pressupostos da vida cotidiana e, portanto, exige dos indivíduos medidas normalizadoras que lhes permitam enquadrar a experiência geradora de ruptura em esquemas interpretativos, possibilitando a sua reintegração a zonas não questionadas do mundo na vida cotidiana. A doença muitas vezes constitui uma situação que revela a insuficiência de um estoque de conhecimento para lidar com o nosso 
dia-a-dia e, por conseguinte, mobiliza os indivíduos a buscarem novas receitas práticas para explicar e lidar com o problema. Neste aspecto, não é de se estranhar que o conhecimento que as pessoas têm e relatam acerca da doença é algumas vezes marcado por contradições e vastas zonas de imprecisão: estas refletem o conjunto de experiências por meio do qual tal conhecimento foi e está sendo adquirido." (RABELO e ALVES, 2004 p. 198).

O que enfatizo é o desenvolvimento de um modelo de corpo produtor e quando não conseguido este ideal o corpo passa a ganhar conotação de doente. Seria como se estivéssemos sempre doentes, sempre buscando o corpo ideal que correspondesse à produção ideal de capital. $\mathrm{O}$ corpo pode ser tanto idealizado com o vigor da juventude como pelo acúmulo de conhecimentos com o passar dos anos.

O que se considera doença e saúde através de uma contextualização social pode se referir aos novos moldes exigidos pelo mercado de trabalho, as competições e qualificações exigidas. Como SENNET (2004) diz, a atual burocracia impõe ao trabalhador uma nova postura: ser flexível, isto é, romper laços tradicionais permanentes em oposição às novas configurações sociais restritas ao trabalho. Os laços com o lugar onde se nasce e cresce já não são suficientes, o trabalho já não é parte de uma localização fixa que une laços tradicionais, como os construídos pela família, e pela formação profissional, ocorrendo uma trajetória considerada conhecida, segura. $\mathrm{O}$ atual trabalhador desenvolve características pessoais restritas ao ambiente de trabalho, formando um caráter para o trabalho, para a manutenção dos ganhos financeiros, para o responsabilizar-se quando não se considera suficiente, individualizando culpa.

De acordo com SENNET (2004), já não é mais um administrador que coordena uma produção, é toda uma coletividade que passa a dizer sobre as insuficiências, em um medir constante a partir do outro, da concorrência de limites. Assim, pode-se notar em algumas das pessoas que entrevistei os deslocamentos impostos, trabalhando em lugares distantes de suas famílias, de um trabalho que anula rotinas, anula os horários de trabalho fixos, dos empregos fixos. Aqui, o trabalho em equipe é destacado como bom, vigiam a rua enquanto vigiam-se a si próprios ao mesmo tempo em que se vigiam coletivamente, não mais existindo um 
chefe que avalia, mas uma coletividade, tornando ainda mais difícil a localização de uma hierarquia nas relações de poder entre patrões e empregados, pois são os outros nas "mesmas" condições e as metas exigidas é que ditam o controle sobre o trabalhador, como diz Dagoberto:

"o segurança tem uma rotina que você tem que enxergar pros quatro lados, é pra frente, é pra trás, esquerda e direita, você tem que ficar ligado, trabalha muito com a cabeça, não é tanto com o corpo e chega o momento que você deita aí e o corpo relaxa, mas a cabeça você não consegue desligar, vive muita pressão, a pressão é muito grande, até na época o médico falou pra mim mudar de profissão, eu falei 'doutor, mudar de profissão que jeito, o que eu sei fazer é isso, sempre fiz isso'. Então, não tem como eu mudar de profissão pra ganhar salário de faxineiro, largar uma coisa da noite pro dia, de uma coisa que é certa pra ser faxineiro, limpador de banheiro, falei 'não tem como doutor', tá no sangue, a profissão é essa, então o que eu quero é sarar. Continuei na mesma coisa até hoje, só que mais tranqüilo, inclusive hoje eu já não trabalho no mercado. Agora a tensão é até maior porque eu trabalho na rua, nós somos uma equipe de quatro, de quatro pessoas, mas cada um fica num canto, trabalhamos com rádio e tudo. Então a tensão é ainda muito mais forte, qualquer veiculo que você vê na rua, qualquer pessoa transitando pra você já é suspeita, então a tensão é grande, né, então eu peço muito a Deus pra que isso não volte novamente. Trabalho a noite ainda, toda noite, o bairro é quieto, mas sempre acontece. O médico falou que 'só o remédio não vai te ajudar', então tá bem, estou alimentando bem pra não volte o descontrole do serviço."

Na parte antiga do bairro pude encontrar um bar, que ficava próximo a minha casa, que, ao passar em sua frente, notei todos os dias a existência de um mesmo público sentado a sua porta: todos homens, sendo em sua maioria senhores, e como disse um dia o dono do bar "aqui todo mundo é conhecido". Vi esse bar como lugar de lazer que aqueles homens sentavam ali no final de tarde, ficando até as nove da noite, horário em que era fechado, o dono fazia a distinção clara de seu bar sobre os outros próximos à favela, dizendo que ali tinha todo tipo de gente, e o dele as pessoas se conheciam e bar possuía horário para fechar. Observei que dois jogos eram realizados nesse bar: dominó e o truco, jogos que dizem muito sobre a associação entre os participantes daquele lazer, dado por juntar peças iguais, buscar o semelhante, até que todas as peças sejam ligadas entre si e a pessoa que consegue dispor de todas as suas peças será o vencedor. O truco, jogo que ocorre em dupla, os 
participantes combinam por sinais as jogadas e as intenções falsas para enganar os adversários, são sinais sutis, não notados. Os rostos dos jogadores devem enganar, promover ao outro idéias errôneas sobre as cartas dos adversários. Notei que numa etnografia existe muito desses jogos, muitas vezes me vi como uma peça que não pode ser juntada com outras pessoas dos bairros, não sendo a combinação correta, ao mesmo tempo em que muitos sinais enganaram-me, palavras, sorrisos e olhares não compreendidos.

São momentos em que o pesquisar encontra o imprevisível, o estranho para ele, enquanto para os entrevistados são acontecimentos rotineiros, sem expressão, que são muitas vezes produzidos para enganar, como ocorre no carteado (SILVA, 2000). Nesse bar, não foi somente ir e ficar lá, visto que é um lugar freqüentemente condenado pelos serviços de saúde, ser um profissional de saúde provavelmente não seria uma boa representação para que as pessoas ali falassem sobre suas vidas, foi com várias idas que o atendimento do dono tornou-se mais amigável, acredito que demorei a ser reconhecido como um freguês, nascendo os comentários de um ambiente masculino, não freqüentado por mulheres. Como SILVA (2000, p. 32) diz, a inserção ao campo de pesquisa e a aproximação com a população exige muita dedicação e paciência: “é preciso ter acesso ao grupo, familiarizar-se com ele, enfrentar conflitos, aprender regras a duras penas, até que se estabeleça um clima de confiança mútua e colaboração". Nesse sentido, a observação participante sobre assuntos considerados masculinos foram surgindo, a impotência sexual foi tida como uma ameaça à felicidade, sendo os medicamentos para impotência vistos simbolicamente como antidepressivos, revelando reflexos de uma sexualidade masculina medicalizada, reduzida ao desempenho sexual (GOMES, 2008).

De acordo com GOMES (2008), existe a necessidade de focalizar ações específicas à saúde do homem, desenvolvendo mecanismos que facilitem seu acesso aos serviços de saúde de atenção básica, contribuindo para que ocorra promoção de saúde, visto que os homens são acometidos de determinadas enfermidades devido a questões relacionadas a gênero. $\mathrm{O}$ autor enfatiza que os comportamentos masculinos relativos à saúde são somados ao fato de que nem sempre os serviços de saúde estão 
preparados para promover um atendimento voltado para o homem, destacando a distância dos serviços de saúde dos trabalhos dos homens, horários de atendimentos dos serviços de saúde, além de concepções de que os homens são fortes e por isso não adoecem, reforçando o medo de ficarem doentes e se mostrarem fracos, e de que a atenção básica possui um atendimento voltado somente a mulheres e crianças.

Acrescento o estudo de BOLTANSKI (1984) que observou que homens e mulheres possuem diferentes modos de cuidar do corpo de acordo com o seu habitus, envolvendo desde o nível educacional até condições financeiras, mostrando que os homens pertencentes às classes sociais mais abastadas possuíam um cuidado mais atento ao corpo do que os homens com menores condições financeiras, sendo aqueles criticados por estes devido aos "excessos" de cuidado, chamando-os de efeminados.

A masculinidade é perpassada por significados históricos envolvendo as relações de poder, levando a pensarmos qual seria sua localização na estrutura social, o que levaria a definir o ser masculino. Nesse sentido, OLIVEIRA (2004) nos diz que a masculinidade estava na Segunda Guerra Mundial voltada para a potência, para o vigor e a força, para as grandes batalhas, para a guerra, enquanto na atual sociedade volta-se para o autocontrole, para o mercado consumidor. A masculinidade está voltada para o desempenho, para as melhores performances do corpo, o masculino estaria mais próximo das exigências físicas do corpo e por isso mais próximo dos grupos populares e distante dos burgueses, a masculinidade se fixa como força produtiva. Desse modo, a masculinidade define territórios, lugares e atitudes, criamse ideais. Como foi observado, os medicamentos psicoativos colaboram na definição atual de modernidade, o estender os limites do corpo.

\subsubsection{Conflitos de gênero: a casa aberta à rua}


Não seria possível em uma análise envolvendo masculinidade, feminilidade separar homens e mulheres, assim como os conflitos de gênero. Contudo, homens e mulheres possuem perspectivas diferentes e que são relacionais. Quando entrevistei Ione, doméstica, nascida em uma pequena cidade do interior paulista e criada pela avó mineira, percebi que os medicamentos psicoativos utilizados estavam envoltos por conflitos de gênero, muitos representados pela violência social e familiar. Ione disse que começou a utilizar os medicamentos psicoativos (fluoxetina e diazepam) desde o ano anterior, inicialmente devido ao marido consumir muita bebida alcoólica, porém com o decorrer da entrevista relatou alguns acontecimentos de sua vida que colaboraram para o consumo dos medicamentos e que estavam ligados à relação entre favela e bairro antigo, não restrito ao ambiente familiar.

"Tomar esses remédios mesmo foi por caso do meu marido, que bebia (..) agora ele deu uma parada, só bebida (...). Eu sempre fui assim, mas de uns dois anos pra cá foi piorando, era muita tristeza e eu não conseguia me abrir com ninguém. A única pessoa foi a doutora daqui do núcleo, foi com ela que eu consegui abrir (...). Chorei muito. Foi numa consulta de rotina. Eu tomo do jeito que é prescrito, a fluoxetina de manhã, mas o diazepam eu já tomei mais, pra fazer efeito, mas já parei, foi por mim mesmo. (...) Se o meu marido continuasse do jeito que estava, eu acho que ia aumentar os remédios (...) Eu dei uma parada, fiquei 20 dias sem tomar ele, dai achei que precisa dele de volta."

As questões sociais nem sempre são ditas como justificativa para o consumo de medicamentos psicoativos, o ambiente familiar torna-se o primeiro culpado, o fato de sua mãe, falecida há 18 anos e abandonada pelo marido quando Ione nasceu, e que a queria envenená-la e pelo fato de Ione ter tentado suicídio com 12 anos com a ingestão de água sanitária não são tão destacadas como justificativas quanto o consumo de bebida alcoólica pelo marido. Ione diz que providenciou uma maneira para que o marido deixasse de beber: "foi um irmã dele que conseguiu o remédio pra para de beber numa farmácia. O marido da amiga dela toma, dai indicou, tá no segundo frasco já." Ao identificar pontos no ambiente doméstico geradores de conflitos, uma solução medicamentosa torna-se uma saída aceita, seja pelo "remédio para parar de beber", seja nos medicamentos para controlar o humor. Os conflitos internos ao lar passam por um processo de individualização, procurando esquecer as 
questões sociais, a violência no bairro tanto no presente como no passado, reduzindo a justificativa de todos os conflitos e do consumo de medicamentos psicoativos ao ambiente da casa, levando simbolicamente a casa a ser medicalizada, isto é, os conflitos envolvendo seus moradores: "Ele fica cutucando, viro bicho, eu sou muito nervosa também. Por que assim, eu tinha vontade realmente de me matar, sabe, chegava ao ponto, o que me impedia era meus filhos, porque eu tenho filhos, um de 3 e outra de 4 (..). Foi só uma vez, quando eu tinha 12 anos, tomei um copo de água sanitária. Queria morrer mesmo, eu nunca fui muita feliz”.

As questões relacionadas ao ambiente fora de sua casa, ao bairro são ditas como colaboradoras para o consumo de medicamentos psicoativos, mas em um segundo plano, sendo enfatizadas quando batem a sua porta. A casa de Ione estava localizada na rua que dividia favela e bairro antigo, ficando do lado da rua mais próxima à favela. Foi nesse ambiente de encontro entre casa e rua, entre o mundo público e o privado, entre o considerado mundo masculino e o mundo feminino (DAMATTA, 1997) que o consumo de medicamentos psicoativos pareceu perpetuar ao medicalizar os conflitos desse encontro. Ione relata que já gostou muito de morar ali, mas que agora, mesmo antes sendo considerado muito violento, que tinha perdido o primeiro marido, pai do primeiro filho, morto na "guerra das favelas", como foi chamado por muitos moradores os atritos entre a favela e um pequeno grupo de moradores também pertencentes à parte antiga do bairro, formado por uma família e pessoas próximas, vivendo em moradias semelhantes aos da favela (e chamada de favela por seus moradores), mas em meio ao bairro entre um prédio e casas, um lote de propriedade de uma senhora com várias casas interligadas, a mãe e avó da maioria de seus moradores.

Tive uma boa conversa com esta senhora, mãe de 12 filhos, disse que possuíam uma origem rural e quando chegou ali era tudo cana, não tinha casa, mas que seu lote era comprado e pago com dinheiro honesto, dinheiro de seu trabalho, e que fez muita faxina, lavou muita roupa, na capina e que gosta muito dos vizinhos, dizendo que ali ninguém tinha problema dos nervos e que não tomavam medicamentos psicoativos, que gostava de festas que não existiam mais, "não 
agüentava uma fogueira de são João" que estava lá festando e bebendo e depois trabalhando no outro dia. Disse que sua primeira casa não suportou a chuva, que a derrubou, a água era de cisterna, e com muita dificuldade criou os filhos, mas que "filho criado, trabalho dobrado". Relatou que não sabia o porquê da "guerra", que de repente começaram a brigar uns com os outros. O lote ainda preservava um ambiente rural, com galinhas, cachorros, árvores fazendo sombra.

A "guerra das favelas" foi descrito por Ione como um ambiente com normas e agressões, mortes violentas: "dava seis horas da tarde, ninguém sai mais pra rua, contava as pessoas". A "guerra das favelas" foi justificada não em decorrência do tráfico de drogas, mas ao roubo de um vidro de perfume e de um tênis na favela "pelos lá de baixo", que procurando vingança começaram a matar uns aos outros, tendo o envolvimento também de um de seus irmãos, não sendo morto porque ela era amiga também da favela debaixo. Em segundo plano, a "guerra" foi justificada pela venda de drogas, mas que existia uma diferença entre favela debaixo, a droga era somente mais um item que complementava a rivalidade, mas as pessoas que morreram estavam envolvidas na venda e consumo de drogas. E que antes da guerra, eram amigos, jogavam futebol juntos, que depois delimitaram o ambiente de cada um: "não podia passar pra lá do mercadinho, não podia nem andar. Quantos vezes saímos fugidos por causa desses... Mirava e mandava tiro. E se eles viessem aqui, também os daqui davam tiros. Ai depois que apaziguou tudo, eles vem aqui jogar bola na quadra, apaziguou tudo". Relata que a religião ajudou muito as pessoas da favela, que agora nem vendiam muita droga, que ali "deu o que tinha que dá".

A casa de Ione foi mostrada a mim como lugar de divisão, como separação pelos muros que antes não existiam. Ione agora estava dividida da favela, esta ficando nas costas de sua casa, levando a fixar-se no mundo privado do lar, cuidando de seus filhos, enquanto o seu marido, trabalhador da construção civil como pedreiro, pertencia ao mundo da rua, dos negócios. A violência ocorrida no percurso de sua vida na favela mostrava-se menos agressiva do que sua situação atual, dizendo que antes a vida era melhor ali. Ione me mostrava que as relações de poder envolviam tempo e espaço, a "guerra das favelas" era utilizada para falar de um outro tempo, 
definir sua vida e o resultado dessa "guerra" as conseqüências sobre sua vida, a fabricação de um novo tempo e de um novo espaço, mesmo morando a poucos metros de onde morava no tempo de "guerra". A "guerra das favelas" e as diferenças entre os bairros diz muito sobre a relação tempo/espaço, como DAMATTA (1997) mostra: tempo e espaço não são categorias homogêneas e evolucionistas, mas reveladoras de rotinas e modos de vida diferentes, entrelaçados pelas relações de poder na sociedade brasileira. São espaços e tempos criando um ambiente de fronteira, de conflito, revelador de diferenças. As diferenças entre os bairros revelam diferenças de tempo, são acontecimentos singulares norteando o dia-a-dia e orientações temporais e espaciais. Além disso, papéis definidos previamente são questionados, homens e mulheres transitam entre os diferentes papéis que ora são de um, ora são de outro, revelando mudanças no comportamento. São esses conflitos, essas fronteiras, que se transformaram em foco da medicalização, que se orienta também pelas relações de poder.

São os diferentes espaços que também ditarão o que se pode ser dito, são ambientes de julgamentos e aceitação, por isso, como DAMATTA (1997) diz, os discursos de uma mesma pessoa serão diferentes dependendo do local onde se encontra, como a rua e a casa. O discurso está perpassado por relações de poder e resistência que são orientadoras, acredito que caso o marido de Ione estivesse presente a entrevista seria outra entrevista, assim como se um agente comunitário de saúde estivesse acompanhando.

Esse ambiente de conflito, de fronteira, em que me encontrei mostrou-me o entrelaçamento entre ciência (medicamentos e modelo biomédico), espaço público (rua) e o da casa. A ciência colaborando para criar uma rotina, contribuindo para o estabelecimento de normas, de patrões impostos ou modelos de um grupo social sobre o outro. Ione e o seu marido estão agora medicados, sendo os medicamentos estabelecedores de comportamentos aceitos, ela restrita ao ambiente doméstico e ele ao da rua, do trabalho. Antes, as ações do Estado, mais distantes, possibilitavam a formação de um grupo unido, pronto para a "guerra" contra aqueles que os questionavam, mesmo vivendo em condições semelhantes. Agora, o Estado mais 
próximo, ao impor um modelo de comportamento e não conseguindo promover regulações, tem nos medicamentos psicoativos um colaborador, manipulando espaços e tempos. As casas da favela, formadas com pedaços de madeira e papelão com frestas, com lacunas entre uma pessoa e outra, são substituídas por tijolos, lugares fechados, impermeáveis aos olhares, cada cômodo ganhando uma utilidade, um significado. Os caminhos ou trilheiras tão próximos, quase unindo as frentes das casas, conhecidos somente pelos moradores, são agora ordenados pela rua, larga, asfaltada, os barulhos são contidos, as pessoas passam a se estranhar. O corpo deve ser (auto)controlado, o medicamento psicoativo passa a ser um fator importante para manipular a vida cotidiana. $\mathrm{O}$ ambiente caloroso de antes, do qual Ione gostava, dá lugar ao impessoal, uma impessoalidade que pode ser insuportável, os medicamentos psicoativos surgem como um auxílio. Nesse sentido, toda a violência passada por Ione não se transforma numa justificativa para o consumo dos medicamentos, mas a sua vida privada relacionada com o seu marido. A vida de Ione e de sua família irá se assemelhar com a dos moradores da $\mathrm{COHAB}$, como se verá adiante, a urbanização chega antecipada à casa de Ione.

Ione me levou a lembrar da descrição que DAMATTA (1997) fez do romance de Jorge Amado "Dona Flor e seus dois maridos". Dona Flor, viúva de Vadinho (que mesmo depois de morto continua a fazer visitas a Dona Flor), personagem boêmio, sensual, irresponsável, incerto, alegre, público, pessoal, enquanto o seu segundo marido, o farmacêutico Teodoro Sampaio, é o homem da ciência, da casa, impessoal, do trabalho fixo, é um homem com rotina previamente determinadas, das certezas, da previsibilidade: "o Dr. Teodoro traz a felicidade pela cura metódica, científica, disciplinada, pelas fórmulas e remédios, pelos livros, por sua prática honrada e regular, por sua farmácia" (DAMATTA, 1997, p. 124). Pode-se dizer que aqui existe uma batalha entre o Dr. Teodoro e o Vadinho, uma luta contra o que cada um representa. Dr. Teodoro impõe um novo modelo ao mundo popular, ele se metamorfoseia em modelo biomédico, em medicamento, seria como se o Dr. Teodoro passasse a ser não notado e a medicalizar Dona Flor, fazendo Vadinho desaparecer, e caso aparecesse, existia uma fórmula medicamentosa esperando-o, 
adaptando as novas normas sociais. A ciência perde a relação com o cuidar e o respeito às diferenças socioculturais e se coloca como normatizadora, Dr. Teodoro, vaidosa ciência, quer se fundir com Vadinho, fazer deste seu igual, quer de Dona Flor um único comportamento. Os medicamentos psicoativos padronizam comportamentos, impondo um poder definidor de sujeitos, do que se considera socialmente como normal. Hoje, Dona Flor estaria utilizando medicamentos psicoativos, possivelmente Vadinho seria visto muito pouco, outros iguais a Teodoro teriam um novo aliado, os medicamentos.

É a busca para se superar e se misturar às imposições que também se torna uma justificativa para o consumo de medicamentos psicoativos. O "normal" se impõe medicalizando, dizendo quem é considerado insuficiente, alcançando não só indivíduos isolados, mas toda uma família, reafirmando discriminações, como me disse a entrevistada Carla (25 anos, casada), revelando dificuldades para conseguir um emprego por ser moradora da favela, a poucos metros da rua limite de asfalto, mas que tinha apoio da família que moravam ali perto, vindos do Estado do Ceará. Carla me perguntou se eu sabia de alguém que estava precisando fazer faxina, que não estava conseguindo emprego. Os medicamentos psicoativos foram consumidos devido a relação entre sentimentos subjetivos, corpo biológico e imprevisibilidade do dia-a-dia: "tenho problema de insônia, tive depressão pós-parto, com muita crise nervosa, com muito choro, não podia conversar. Eu peguei aí (núcleo), ela me receitou o diazepam e fluoxetina também pela depressão, teve muito problema, tive o cunhado que foi preso (...) o diazepam me deixa calma, só que a gente não pode tomar muito porque fica dependente." ANDRADE e col. (2006) destacam que a depressão pós-parto resolve em sua maioria sem medicação em até seis meses, sendo de pouca prevalência (de $10 \%$ a 15\%). Entretanto, a depressão pós-parto deve ser problematizada, visto que os conflitos surgidos devido a sua ocorrência podem prolongar-se, produzindo um permanente julgamento e violência sobre $\mathrm{o}$ comportamento da mulher. A depressão pós-parto pode ser compreendida como questionamento dos papéis que a mulher deve desempenhar como mãe e cuidadora, o que pode não ser compreendido pela própria mulher, criando impasses entre os 
desejos de assumir seu papel predeterminado e a dificuldade em seu cumprimento, possibilitando que a mãe seja levada a uma espécie de autojulgamento, propiciando que a violência sofrida seja silenciada por se culpar.

RABASQUINHO e PEREIRA (2007) encontraram elevado consumo de antidepressivos $(40,2 \%)$ e ansiolíticos $(41,6)$ em população usuária do serviço de psicologia de um hospital na cidade de Castelo Branco, Portugal. Além disso, observaram que as mulheres são as maiores consumidoras, possuindo maior prevalência (aproximadamente o dobro dos homens) de transtornos relacionados ao consumo destes medicamentos como os de humor e de ansiedade, enquanto os homens tiveram maior prevalência de transtornos relacionados ao uso de álcool e comportamento anti-social. ANDRADE e col. (2006) destacam a maior vulnerabilidade das mulheres à depressão e à ansiedade, provocando mortes e incapacitação, enfatizando seus surgimentos em decorrência da violência contra a mulher e aos distúrbios hormonais devido a sua variação que ocorre durante a vida das mulheres, ocorrendo maiores chances de consumo de medicamentos psicoativos.

Outra entrevistada que relatou insatisfação com a favela foi Áurea, também moradora a poucos metros da rua asfaltada limite e com 37 anos, que me relatou a importância dos medicamentos na sua vida cotidiana, ampliando não só para os medicamentos psicoativos, mas para todos os medicamentos, principalmente os utilizados para dor, gastrite e "má digestão":

"Eu me medico bastante, eu tomo muito diclofenado, eu tomo pra dormir, pra dor, pra dor no dedão, pra dor na barriga, pra dor de cabeça, pra dor no joelho, um remédio que eu não fico sem. Agora eu tô tomando um outro remedinho azul que é pro estômago, agora eu tomo o remedinho azul e tomo o diclofenaco e tomo um remédio (...), um pra tirar dor no estômago, que dá no posto. Não vivo também agora sem o omeprazol, se como uma lasanha eu tomo omeprazol, se eu como um inhoque, eu tomo omeprazol, é omeprazol 24 horas também, quer dizer, eu tomava também muita novalgina, nossa, era um vidro de novalgina. Eu tenho uma dor de cabeça desde criança, é uma dor de cabeça infernal, parece que vai acabar o mundo, parece que eu vou morrer, parece que eu vou morrer, antes a gente ia e mandava diclofenaco. Vai fazer 10 anos que tomo diclofenaco, não tem outro remédio, muito diclofenaco, antes era muita amoxicilina, tomei bastante." 
Os serviços de atenção primária são criticados em relação aos serviços de atenção secundária e terciária, como o Hospital das Clínicas e o Centro de Saúde Escola. Os serviços de atenção primária, como o Núcleo de Saúde da Família são vistos como uma fila a mais, pois o que é dito como resolutivo são os serviços de alta complexidade e lugares que tenham dispensação de medicamentos: "lá no núcleo é uma enrolação, um vai e vem, nem fui, é uma enrolação, sempre falando pra gente voltar depois, que acabou as vagas da pro cê vim as 8horas, ai depois fala ah vai na CSE (...) O serviço não trás o remédio, não trás a cura, não trás a ajuda”. Os medicamentos são utilizados de acordo com a experiência aos efeitos no corpo, fazendo parte das relações de poder dentro do lar e ao trabalho fora, fazendo parte dessa relação os serviços de saúde e os medicamentos. Áurea trabalhava como cabeleleira, tendo que realizar tanto as tarefas domésticas como de seu trabalho, estabelecendo também, como os homens entrevistados, uma busca constante para superar-se, somando o trabalho doméstico com trabalho externo ao lar. As mulheres se desdobram em busca de uma liberdade de trabalho e autonomia fora do ambiente doméstico enquanto os homens se desdobram como produtores para reafirmar sua posição de provedor, levando a competição entre homens e mulheres ocorridas dentro do lar a ser um mecanismo de exploração capitalista. Desse modo, os medicamentos psicoativos consumidos fazem o diálogo entre esses dois mundos, o da casa e o do trabalho:

"O antidepressivo entra na minha vida assim, quando eu tô muito desanimada e não tenho vontade de fazer nada. As enfermeiras do núcleo dizem que não funciona assim, mas eu tomo de noite e no outro dia é aquele pique total, a enfermeira disse que demora pra fazer efeito, eu limpo, lavo, passo e começo a correr atrás de minhas clientes, entendeu? Elas (enfermeiras) dizem que assim não faz efeito, falam então pra tomar uma pirulinha de açúcar que vai fazer o mesmo efeito, eu falo que sei que uma pirulinha de açúcar eu não tem o mesmo efeito. Eu, pra mim, faz efeito. Se tá me fazendo bem pra mim, não tá prejudicando a minha saúde o quê que tem eu tomar, eu falo pra elas. Elas falam 'não Áurea não pode tomar assim', você tem que tomar direitinho. Eu falo eu vou tomar assim, tá bom pra você, dá pra mim, dá a receita, se não me der a receita do médico da manhã, eu vou no médico da tarde, se não me de a receita do médico da tarde, eu vou no outro médico de manhã cedo, até eu conseguir a receita, e consigo. (...) Tinha um médico daí que me dava três, dois (vidros) de 
omeprazol, o doutor fala 'oh, vai...', eu falo 'oh doutor, eu preciso de diclofenaco por causa da dor de cabeça, quando vem dói, quando acaba dói, e eu preciso da receita que é uso continuo', ai ele vai lá e faz. Igual eu tô te falando, eu tô cortando o remédio da minha vida, tô tirando, antes você ia na minha casa eu tinha estoque de amoxicilina, amoxicilina infantil, o menino já tossia, eu já chuchuva nele, remédio pra alergia de tudo quanto é jeito, pomada pra machucado de tudo quanto é jeito, então agora eu não tenho nada, que nem agora eu tô desesperada porque o meu diclofenaco acabou, mas oh, já vai um mês que eu não tô indo buscar, eu tô assim, eu tô com duas pílulas só em cima da geladeira, Eu falo 'deixa ficar doendo', mas ai eu acho que dá pra agüentar, deixa lá,(...) agora o omeprazol eu tô com um punhado em casa (...)."

O consumo de medicamentos psicoativos, ao colaborar para produzir um corpo disposto tanto para a execução de tarefas no ambiente doméstico quanto fora através do trabalho, combina questões relacionadas ao gênero e à classe social. Ao marido é imposta uma ordem através dos medicamentos, o uso de um antidepressivo não só significa um estado de quem toma e supõe necessitar dos medicamentos naquele momento, mas um chamariz para traduzir o não dito para o marido, os medicamentos passam a moldar o dia-a-dia do casal, dizendo para o marido o que se deve fazer. O consumo de medicamentos psicoativos faz com que as fronteiras entre a condição de vítima e acusado se confundam, podendo a resistência reverter-se em poder:

“Fluoxetina eu tenho uma caixa lá, eu pra mim assim 'vou largar agora' (do marido), vou entrar em depressão, eu vou largar do meu marido, porque toda a vez que eu largo dele eu entro em depressão. Eu falo pra ele, mando ele embora, dai eu não lavo, não cozinho, não faço nada pra ele, aí ele fica lá esperando eu passar o meu nervoso. Ele fala 'você é louca, você é doente', dai ele come no serviço dele, nos irmãos dele, fica sem comer, lava a roupa dele (ri)."

O consumo de medicamentos psicoativos é também orientado de acordo com a experiência de uso, e os ansiolíticos são vistos com desconfiança devido a dependência que este pode causar, e por isso evitam tomá-lo continuamente, promovendo intervalos para evitar a dependência medicamentosa (MENDONÇA, 2005). Contudo, o medicamento antidepressivo é disseminado como inofensivo, como "uma pirulinha de açúcar", levando a ser consumido com mais intensidade 
quando comparado aos ansiolíticos. Os medicamentos ansiolíticos possuem uma conotação simbólica por serem dispensados mediante receita azul e as caixas dos medicamentos são de tarja preta, sendo temidos e associados com transtornos mentais mais graves do que a sua própria, como também Dagoberto revelou. Os antidepressivos se assemelham a outros medicamentos, são adquiridos com receitas brancas e a tarja da caixa é vermelha como os medicamentos vendidos sob prescrição médica.

As entrevistas me fizeram refletir sobre um verbo "juntar", que foi muito utilizado formando expressões como "foi juntando tudo", "juntei com ela(e)" revelando um percurso de vida que soma trabalho fora do lar com o trabalhado no lar.

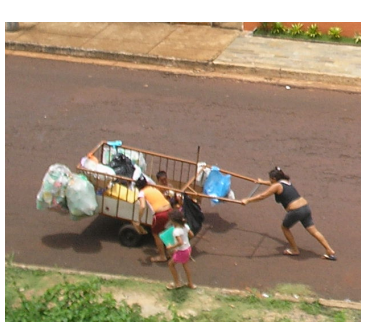

Como pude observar, haviam muitas pessoas que trabalhavam na reciclagem de materiais, "juntando coisas", garrafas, papelão, latinhas, sendo vistas várias pessoas com carroças e carrinhos de mão feitos pelos próprios catadores desses materiais, passando e colhendo os materiais dos lixos

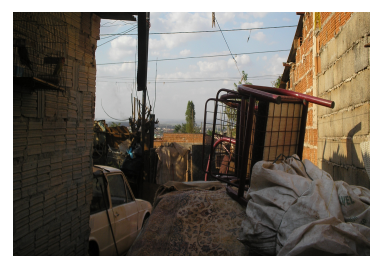
postos na frente das casas. Pude ver algumas famílias inteiras de catadores, filhos e pais, ou somente o casal. Algumas pessoas coletavam somente no final de tarde, tendo outros trabalhos durante o dia, como o de doméstica. Encontrei

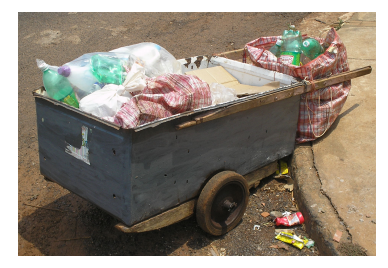
algumas casas com grande quantidade desses materiais, estocados para serem preparados para a venda. O trabalho das mulheres, além de catadoras de papel, também era muito destacado como de faxineiras, lavadeiras, passadeiras,

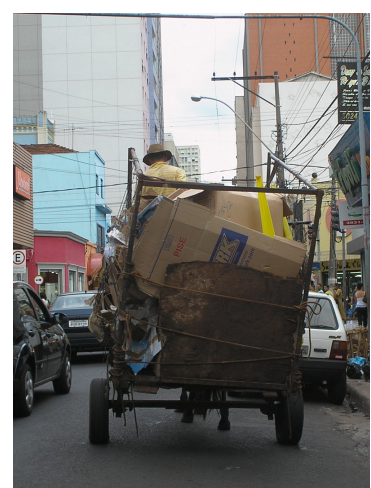
trabalhando tanto em suas casas como em outras, um trabalho pouco reconhecido.

A relação do trabalho com reciclagem e trabalho doméstico foi mais destacada dentro da favela. Entrevistei Mirla, casada, com 44 anos de idade, vivendo com seu marido, 3 filhos e um neto. Trabalhava ela e o marido na 
reciclagem e relatava com orgulho sobre seu trabalho, destacando que hoje estava concorrido, que tinha muita gente catando os materiais, e que o governo não a ajudava e, caso ajudasse, seria apenas uma troca: "não tenho nada de governo, eu não devo nada pro governo, devo assim, é só esses remédios aqui que eles me dá. Dinheiro daqui é eu trabalhando, meus filhos." Mirla me disse que já não estava tomando o ansiolítico, somente o antidepressivo e que era devido à morte de um neto de forma trágica, sendo sua cuidadora:

"A depressão foi uma perda de um neto que eu tive, ele tinha 6 meses (...) Ela (filha) largou o filho comigo, dai quando ele tava com seis meses, ela veio e levou ele pra casa dela pra passear e deixou ele cair, veio muito problema, porque ele já era uma criança especial, então ele não era um nenê normal. Eu tenho mágoa dela, não consigo perdoar, porque ela tirou o menino, ele tava tomando sol, quietinho no carrinho, ela me tirou o menino vivo pra mim trazer morto (...) Não somos amigas, ela vem aqui em casa... não foi somente do tombo, porque o rapaz que ela morava junto deu cocaína pra ele, dai o narizinho dele tava assim com aquela farinha. Ela falava que não era, que era pó pra espirrar."

Trabalhos não remunerados sobrecarregam um dia-a-dia conflituoso, seja para as moradoras da favela como Mirla e Nara (referida adiante) ou para as moradoras da parte antiga do bairro como Eula (25 anos, morava com o marido e uma filha). Eula também mostrou que o cuidar de doentes, quando somado a morte dos mesmos, provoca o consumo de medicamentos psicoativos devido a, além da condição de trabalho desgastante, se sentir insuficiente. Como foi verificado, as insuficiências dos homens são tidas como outras. Eula começou seu tratamento no Núcleo de Saúde Mental do Centro de Saúde Escola, porém passando depois a ser medicada pelo Núcleo de Saúde da Família. As mulheres aqui procuraram de acordo com seus ambientes unir várias funções, destacando um conflito de gênero e as imposições econômicas, conciliar trabalho remunerado e não-remunerado:

"Fiquei assim, eu perdi um filho com nove meses de gravidez, ele morreu, dai depois, depois minha filha nasceu, eu engravidei sete meses depois, foi indo, ai foi um monte de problema, ai junta, aí um belo dia explodiu, aí fui no CSE, ai me medicou, mas dai eu ficava dando crise assim uma atrás da outra, ai calmante, calmante, ai ficou assim, qualquer coisa que eu sentia, calmante, ai agora eu comecei a trabalhar e larguei (o calmante) (...). Eu pego a receita, tem dois meses que eu tô trabalhando, a minha irmã pega a 
receita pra mim. (...) O jeito que eu lidava com os problemas... aí você explica pro médico e vamos tomar remédio. Depois que eu descobrir o remédio eu tinha ação e sabia lidar, uma gravidez depressiva, eu não aceitava, depois que a minha filha nasceu (...). Eu tenho vontade de parar, eu fico um mês, mas me sinto mal, dai eu volto a tomar de novo (...) Fiz um outra pesquisa, mas era com resposta sim ou não, mas não deu, teve que liberar o medicamento, diz que tenho que continuar. Eu recuperei da morte do filho, mas vem outras coisas, falta de dinheiro, marido. Um tempo passado eu tava só tomando remédio e dormindo, eu tava assim, ai eu vi que tava muito paradona, eu tava tomando um, dai ele (médico) falou que vamos tomar dois mesmo (...) Eu não posso ficar em casa, se eu ficar a coisa piora."

Como se nota, o nascimento de um filho está muito associado aos estados depressivos de algumas entrevistadas, supõe-se que o nascer de um filho está relacionado a uma maior fixação de uma condição que intensifica conflito de gênero e dificuldades econômicas. Nara (35 anos, casada, mãe de 5 filhos, moradora da favela), também me relatou as dificuldades financeiras, quando o marido, vigilante, ficou desempregado, que o ex-patrão tinha ameaçado por medo que o levasse à Justiça, e que agora vendia “detergente caseiro". Relatou que o marido tinha saído do emprego porque apresentara transtorno mental, mas que agora estava melhor e vendendo "detergente caseiro": "passou o diazepam, eu melhorei bem, passou um mês pra frente, dai eu parei por conta (...) dai eu engravidei, ai teve que parar (...). Eu tava bem, de repente eu comecei a chorar, fiquei uns 5 meses... Na época eu tava desempregada, trabalhava de doméstica, os meninos ficavam com minha mãe”. A história deste casal representa muita outras de pessoas que vieram de outros Estados em busca de melhores condições de vida, trabalhadores rurais vindos de Estados do nordeste brasileiro e de outros Estados como Minas Gerais, Goiás, Paraná. Observei que muitos dos entrevistados, mesmo nascendo em Ribeirão Preto ou em outras cidades do interior paulista, faziam parte, através de suas famílias, de uma construção de um percurso sócio-geográfico em busca de melhores condições de vida, freqüentemente fruto de expropriação de suas terras nos lugares de origem de suas famílias, provocando distinções e permanência de sua subalternidade a outros grupos sociais locais, separando "os de fora", "os baianos", "os mineiros", procurando produzir esquecimentos, reduzindo a memória ao "progresso" adquirido, reafirmando 
sua posição de explorado com ares de vantagens ao reproduzirem o discurso de que suas origens sócio-geográficas são parte de um atraso nacional (SILVA, 1999). Além disso, a migração envolve uma condição de estresse, facilitando o desenvolvimento de transtornos mentais, em decorrência, dentre vários fatores, da separação de pessoas queridas como amigos e familiares e conflitos culturais, gerando sentimento de insegurança, dificuldade de adaptação devido às diferenças de estilos de vida e falta de receptividade do lugar a qual se destinou (HELMAN, 1994). A migração é adicionada a questões relacionadas a gênero e classe social, e como destaca LUDERMIR (2008) em estudo de revisão, as cidades, ao estarem caracterizadas como propiciadoras de transtornos mentais considerados mais comuns, como depressão e ansiedade, produzem diferenças quanto aos grupos de pessoas mais susceptíveis, sendo destacadas as mulheres, trabalhadores do mercado informal, pessoas com baixa renda e escolaridade. De acordo com esta autora, essas pessoas estariam vivendo em condições relativamente desfavoráveis aos demais grupos, marcados por dificuldades econômicas, excesso de trabalho, vivendo em situações de violência, com menos informação suficiente para conseguirem se locomover de situações desfavoráveis. LUDERMIR (2008, p. 461) conclui que as políticas públicas devem considerar em sua formulação as desigualdades quanto aos transtornos mentais:

“As desigualdades sociais envolvem os principais sentimentos relacionados à depressão e a outros transtornos mentais, como humilhação, inferioridade, percepção de falta de controle sobre o meio e impotência. Observa-se, entretanto, que na perspectiva de classe e gênero, as necessidades sociais não são reconhecidas nos serviços de saúde, não se expressam nos diagnósticos formulados e a maioria dos profissionais não presta acolhimento adequado aos portadores de sofrimento mental."

É importante destacar que as pessoas que entrevistei se incluem nas descrições de LUDERMIR (2008), pois eram em sua maioria mulheres pertencentes ao mercado informal, com baixa escolaridade e renda e, além disso, faziam parte de um processo de migração. Essas pessoas estariam relativamente fragilizadas tanto internamente em seu próprio grupo social quanto externamente, em relação aos outros grupos, pois sua condição estaria propiciando o desenvolvimento de conflitos 
mais contundentes quando comparados com o restante da população, favorecendo um processo de distinção.

A distinção se repete à medida que se tem deslocamentos de grupos sociais, reproduzindo as desigualdades econômicas e culturais. Como estratégia das relações de poder na formação de habitus, contribuídas também pela relação entre Estado e medicina ao promover o consumo de medicamentos psicoativos, modula e fixa comportamentos. Nesse processo de fixação de papéis, as divisões entre espaços tornam-se necessárias, como os relacionados ao gênero ou à classe social, fazendo parte de um projeto sócio-histórico.

Como exemplo, tem-se o projeto de urbanização brasileiro ocorrido no século XIX, fixando os homens nos espaços públicos, dos negócios, e que também tinha para a mulher de grupo popular estratégias que procuravam fixar seus papéis no espaço doméstico: mãe, dona-de-casa, submissa e produtora de corpos disciplinados e livres de doenças físicas e morais (RAGO, 1985). As mudanças estruturais das cidades, baseadas em padrões europeus levaram ao controle dos comportamentos nos grandes centros comerciais brasileiros, tendo como pauta o progresso científico e industrial localizado nas cidades, produzindo esquecimentos relacionados ao seu passado em outras regiões, inclusive as diferentes formas de cuidar do corpo, as terapias como as baseadas em plantas medicinais.

CHALHOUB (1986), citando como exemplo a cidade do Rio de Janeiro do século XIX, mostra como as pessoas pertencentes às classes populares foram coagidas, recebendo o adjetivo de "perigosas", revelando como os crimes ocorridos eram reduzidos aos dados objetivos dos acontecimentos, retirando o caráter social dos conflitos, como as competições para vencer o desemprego e o processo de segregação das pessoas mais pobres nas periferias fabricado através da política de saneamento. CHALHOUB (1986) expõe como conflitos violentos eram iniciados no ambiente fabril e prolongados às casas, aos bares. A casa é palco de atritos oriundos da relação entre vida pública e vida privada, da união entre diferentes trabalhos.

Assim, o consumo de medicamentos psicoativos colaborou com seus efeitos no corpo, perpetuando relações de dominação, evitando conflitos e colaborando para 
que as agressões fossem invisibilizadas, não sendo questionadas. A procura por sair das condições de dominação torna-se pessoal, individualizada, fazendo o corpo passar cada vez mais por um processo de exploração ao se estender seus limites à procura de autonomia. Nesse sentido, a violência, os conflitos como questionamentos passam a ser medicalizados, individualizando a culpa e considerando os grupos populares como insuficientes.

A violência social, no mundo público, soma-se à violência do mundo privado, da casa, sendo justificado o uso de medicamentos ansiolíticos e antidepressivos pela morte violenta de parentes e pelas dificuldades socioeconômicas. Os medicamentos psicoativos ora são utilizados para produzir esquecimento, não deixar rancores, ora para aceitar as condições impostas, enfraquecendo reações, resistências. CARVALHO e COELHO (2005), analisando a história de vida de nove mulheres adultas no ano de 2003 com baixa renda, moradoras de Brasília-DF e com diagnóstico psiquiátrico de depressão, observou que suas vidas eram marcadas por situações relacionadas aos conflitos tanto em suas infâncias quanto na vida adulta, como a perda ou abandono dos pais ainda na infância, humilhações e agressões, trabalho, dificuldades econômicas, violência conjugal e sentimento de incapacidade para ser esposa e mãe, culpabilizando-se.

No século XIX, as mulheres avaliadas como imprevisíveis, instáveis e questionadoras e "péssimas" dona-de-casa, mãe e esposa, ganharam a conotação de mulheres "nervosas", "histéricas", "antinaturais", "perigosas", sendo submetidas a tratamentos médicos (ENGEL, 2004), ou mesmo, chamadas de "vagabunda" por não ficarem retidas em seus lares e buscarem sobreviver nos espaços públicos (SOIHET, 2004). Pode-se supor que estas mulheres estariam submetidas a tratamentos disciplinadores, incluindo os medicamentosos, que controlariam seus comportamentos. Nesse contexto, construíram-se, através da relação entre medicina e Estado, estratégias de coerção ao comportamento dito irregular, fortalecendo domínios de grupos sociais privilegiados, e como exemplo pode-se citar o domínio masculino sobre a mulher e a criação de habitus, do rico sobre o pobre. A função dos medicamentos ansiolíticos e antidepressivos é, por um lado, a de reter e controlar a 
mulher nos lares, "regulando" o nervoso e fazendo honrar as obrigações determinadas, sustentando um corpo disciplinado com conotações morais e, por outro lado, colaborar para que o homem permaneça no espaço público, da rua. Quando estes espaços são alterados, a possibilidade de consumo de medicamentos torna-se maior, como o fato de o marido perder o emprego e se sentir humilhado ao mesmo tempo em que se transforma em um incômodo para a mulher dona-de-casa, aumentando os conflitos internos e qualquer tentativa de mudança exige do corpo um desdobramento, um maior dispêndio de energia através do trabalho.

Contudo, o modelo ainda prevalece com muita freqüência, a mulher restrita ao ambiente doméstico e o homem ao trabalho remunerado. A posição do homem como provedor financeiro é garantida pelo trabalho excessivo em busca de maiores ganhos. O modelo de homem trabalhando, mulher em casa, é transcorrido através da entrevista com Talita (45 anos, casada, 2 filhos), Quando cheguei em sua casa, tinha também a intenção de entrevistar sua mãe, mas isso não aconteceu devido a seu falecimento. Talita era dona-de-casa, teve depressão pós-parto e disse que desde então consumia medicamentos ansiolíticos e antidepressivos. $\mathrm{O}$ ansiolítico não era tomado todos os dias: "tomo somente quando eu tou muito nervosa, tomo um comprimido, caso contrário, não”.

Além de Talita e sua mãe, ela me disse que ter um irmão considerado alcoólatra que também fazia uso de antidepressivo. Talita controlava o consumo de acordo com sua experiência com os efeitos deste medicamento: "ele me prescreveu um comprimido, mas eu tomei meio e ainda fez mal (...). Eu não tomo remédio que não estou acostumada, porque me faz mal pro figado". A mãe, acamada, era cuidada por Talita, fazendo com que tivesse grande freqüência aos serviços de saúde, como o Hospital das Clínicas e o Núcleo de Saúde da Família. Os efeitos dos medicamentos eram avaliados por Talita, dizendo que o antidepressivo "deu uma reanimada" na mãe, fazendo com que se movimentasse mais, porém tinha provocado perda de peso, e que o ansiolítico diazepam "dava reação ao contrário." Algumas vezes a mãe ficou internada no hospital, sendo também visitada pelos médicos do Núcleo de Saúde da Família. Talita contou sobre todo o cuidado que teve com a mãe: "ela tava 
com lúpus, aí o medico perguntou quem disse que ela tava com lúpus, eu falei eu, é eu que trago ela aqui". Talita procurava nos tratamentos medicamentosos uma solução para a saúde de sua mãe, criando um grande vínculo com sua mãe:

"oh, um coisa eu vou te falar, eu gostaria dela aqui do jeito que ela tava, mais queria ela aqui, taria aqui junto comigo, eu não conformo com a perda, eu não me conformo com a perda da minha mãe, ela era minha amiga, dava força pra tudo. Eu tenho depressão desde 80, eu tive depressão pós-parto, passei por tratamento psiquiátrico, eu sempre tomei remédio fortíssimo, antidepressivo, só que de vez enquanto eles vão trocando, só que agora eu num faço, não vou no psiquiatra vou aqui no núcleo, eu tomei vários, tomei um monte."

Talita disse que no momento estava tomando menos medicamentos, não fazendo a distinção entre os medicamentos antidepressivos e os ansiolíticos. Além de cuidar de sua mãe até sua morte, também disse que havia cuidado de sua cunhada, que havia morrido de câncer e cuidava naquele momento de seu irmão considerado alcoólatra:

"pelo que eu passei eu acho que estou até bem de mais, eu tomo tryptanol, né (...). Pra você ver, eu cuidei da minha cunhada que teve câncer, foi 8 anos com câncer eu cuidando dela (...), depois o meu irmão que bebe, que mora comigo, ele dava cada trabalho, cansei de procurar a psiquiatria, ele também tomo antidepressivo (...) ele é daqui do núcleo também...o que eu venho passando o que eu venho correndo que eu acho que tenho de tomar antidepressivo mesmo, se não tomasse atrapalha e eu paro (...). Já faz uns seis anos que tomo amitriptilina, só que agora eu to tomando só um (...), doutora falou 'vamos tirando, uma semana cê toma 4, a outra 3, a outro 2 e depois um'. Eu falei que era a mesma coisa de tomar um só, estou tomando 1 há cinco dias, o que vai virar também eu não sei."

A condição de cuidadora exige aqui reconhecimento pelas pessoas que a nomeiam simbolicamente para essa função dentro do lar. Assumir este papel nem sempre é notado como trabalhoso, mas como a internalizarão de uma obrigação: "eu cuidei da minha cunhada, ela teve câncer de mama e depois foi pros ossos, ela fez cirurgia, ela tirou o seio todo. E eu tava ali na luta, eu cuidando dela, faz dois anos que ela faleceu, mas graças a Deus eu estou aqui, com a ajuda dos remedinhos mas estou em pé, com a ajuda do meu marido, ele é uma graça pra mim, que ele é muito bom, os meus dois filhos, ele me dá força total." 
Assim, o Núcleo de Saúde da Família é visto como uma espécie de presente e não como um direito. As ações do Núcleo de assistência ao cuidado de doentes foram apresentadas como mais próximas da população da parte antiga do bairro. O Núcleo, ao colaborar no cuidado cotidiano das pessoas de quem Talita cuidava, possibilitou maior segurança para Talita: "a doença dela (cunhada) também não foi fácil, né, sempre correndo com ela, nossa. Agora uma coisa eu vou te dizer, esse núcleo aqui é um Deus pra mim, a minha mãe tava ruim eu corria lá, eles vinham aqui, olhavam a minha e tudo, o núcleo tratou a minha mãe"

A função de cuidador exige muito empenho, pois a doença começa a fazer parte de uma pessoa que não tem materializada em seu corpo, mas faz parte de seu dia-a-dia, de sua rotina, o cuidador passa a ficar simbolicamente doente, isto é, não como uma somatização, mas como parte da relação doente-doença e pessoa-doença. $\mathrm{O}$ cuidador nem sempre se restringe à relação doente-doença como os serviços de saúde trabalham, o doente interage com o cuidador à medida que este participa dos tratamentos, ampliando para uma relação pessoa-doença, acrescentando a dinâmica destas relações, interferindo na rotina do cuidador e das pessoas envolvidas. Assim, a morte não somente se apresenta como uma perda da pessoa, mas também dos papéis relacionados ao cuidar. E, além disso, estes papéis fazem parte de relações de poder, de gênero, construídas no decorrer da vida do cuidador. O cuidar de um doente acamado em casa, envolve toda uma mudança de rotina, que pode sobrecarregar as pessoas que exercem essa função, seja com o mundo fora do lar, somando às vezes trabalho e cuidados internos no lar, ou como a soma para as donas-de-casa de mais um trabalho não remunerado e pouco reconhecido como tal. As relações de gênero colaboraram para que Talita assumisse essa posição de cuidadora, de acompanhar toda uma outra vida que precisava de apoio. $\mathrm{O}$ ato de cuidar de um doente na família não se restringe a uma pessoa, o cuidador adquire uma função que se expande aos possíveis doentes, não é o cuidador do doente, e sim, de doentes. O cuidador pode muitas vezes se sentir insuficiente, pois a morte pode levar a esta significação, o cuidador passa a se considerar um remédio insubstituível, a morte representa sua insuficiência, fazendo os cuidados sempre se estenderem até os limites. Desse modo, 
outros trabalhos além do de cuidador se somam, sendo às vezes deixados em função de seu papel de cuidador. Os comentários das pessoas que circunvizinham são caracterizados por julgamentos sobre a higiene do doente, seu vestuário, sua alimentação, sua aparência, o que coage o cuidador a buscar uma perfeição. Desse modo, Talita mostra-se preocupada com a aparência de sua mãe, seu peso, sua limpeza:

"Esse é o problema oh, esse que é o problema, tem hora que eu penso 'oh meu Deus, será que eu deixei de fazer alguma coisa pra minha mãe, eu tenho uma irmã e dois irmãos, mas quem cuidou da minha mãe e quem cuidou do meu pai até o final da vida deles, foi eu, eu fui à luta (...) Meu pai morreu do coração, eu penso 'será que deixei de fazer alguma coisa pro meu pai, será que ele merecia mais, será que com a minha mãe eu fiz alguma coisa que ela não gostasse', ai eu vivo me perguntando, né. Ai tá fazendo uns vinte dias, eu tava com uma depressão danada, chorava à noite, de noite, de madrugada eu acordava e chorava e foi muito dificil pra mim, pra mim o mundo tinha acabado, né, mas agora parece que tá entrando na minha cabeça a perca dela, mas não vou te falar que não choro, que choro muito ainda, nossa, a minha mãe esta na minha cabeça, eu entro lá no quarto onde ela dormia, nossa meu Deus do céu, isso pra mim é a morte, eu fico vendo ela deitadinha, quetinha, um montinho, ela era pequenininha, tava magrinha."

Talita continua sua posição de cuidadora, agora com o irmão alcoólatra, dizendo que ele vai ser internado. Os cuidados com o irmão se somaram no passado aos cuidados com a mãe, ela dando os medicamentos, procurando administrar o tratamento: "ele não tomava os remédios, dai pusemos o remédio no pão, ele come é mais lanche. Agora, o doutor falou que não era pra dar os remédios porque ele tava bebendo". O verbo "juntar" representa aqui não só o juntar dos anos, mas a construção de um destino através do gênero, somando-se a cada dia um novo afazer que repete uma norma imposta e internalizada, naturalizada: "é tanto problema, é tudo bem, acho que eu vim no mundo pra socorrer, ai tô até bem, tou passando (...) esses tempos atrás eu não tava em condições de ajudar ninguém, agora eu tou, tou levantando de novo, eu não nasci para cruzar os meus braços."

A função de cuidador também está envolta pelas relações de poder e afetividade. $\mathrm{O}$ cuidar da mãe por Talita não é simplesmente um ato humanitário, faz parte de aprovações sobre sua posição de mulher e dona-de-casa, que possivelmente 
deve ter sido muito abalada com a depressão pós-parto. Cuidar da mãe é também mostrar-se a filha mais qualificada, e ser "escolhida" para essa função torna-se um privilégio para Talita, respondendo às exigências dos pais, pois o cuidar representa um prêmio, mostrar-se qualificada, suficiente como mulher cuidadora. O consumo de medicamentos antidepressivos e ansiolíticos não são justificados por essa condição de cuidadora, mas para o que a questiona como mãe, a depressão é após o parto, mas o consumo de medicamentos se perpetua, levando a reafirmar seus papéis previamente definidos. A depressão pós-parto, ao envolver conflito de gênero, faz parte de toda a família, possibilitando que os julgamentos sejam ampliados.

"Na epoca era pra mim ficar internada no Esquirol, a minha mãe que não deixou, 'não vai internar', ela falou, a minha mãe mesmo que me trocou de medico, de psiquiatra (...) Eu sou magra, eu fiquei um palitinho, a minha mãe e meu marido disseram que não me internar não, ora disseram pro médico 'ela num tá louca', eu morava aqui já, eu sai de manhã cedo a hora que o meu marido ia pro trabalho, um filho meu ficou com a minha irmã, o mais velho, e o que eu tinha, tinha, é, esse caçula ficou com a minha cunhada, né, hoje ele tem 27 anos, o outro tem trinta anos (...). Ai meu marido me levava cedo pra casa da minha mãe, ai meu marido me trazia de noite pra casa, pegava ficava com a cabeça coberta de cobertor, eu só chorava, dai, esse meu filho ficou três meses com a minha cunhada, desde quando nasceu, mas eu fiquei três meses em cima de uma cama, só chorava, ai veio essas remediaiada que eu venho tomando, mas vou indo".

A relação de uso de medicamentos psicoativos nem sempre fica restrita a uma única pessoa, pois os conflitos se expandem por toda uma família ou entre gerações, um motivo é devido à família muitas vezes estar sujeita aos mesmos conflitos envolvendo o espaço interno da casa e o mundo fora desta, um mundo competitivo e racionalizador. Desse modo, pais e filhos e casais vão passar por um processo de medicalização. A união entre mundo do trabalho privado da casa e externo apresenta uma configuração de gênero que tanto para um como para o outro são impostos padrões de eficiência, fazendo comparações em busca de um ideal de mulher e de homem. Para Talita, restrita ao ambiente doméstico e a seus afazeres, é exigida que cumpra suas tarefas com perfeição, o pai muitas vezes se apresenta como um patrão avaliador, qualificador para a execução dos futuros trabalhos da filha, reafirmando o não reconhecimento do trabalho doméstico como trabalho: 
"O meu pai também tomava diazepam, a família inteira dos antidepressivos, a família inteira, mas a minha irmã e meu irmão não sabem o que é médico. A gente sofreu com meu pai. O meu pai era nervoso, era brabo, a gente sofreu com ele, a minha mãe passou uns bons bocados com ele, vige maria coitada, sofremo com ele na vida e na morte. O meu pai era demais, não podia ver uma colher cair no chão que já falava, não podia ver coisa no chão que já falava, fazer o quê, era o jeito dele (...). Aquela época, nossa, Deus me livre, nossa senhora, o que eu passei com meu pai, ele era exigente pra caramba. (...) Sempre trabalhei em casa, mas se eu tivesse, se trabalhasse pra fora talvez seria melhor para mim, eu preferia, mas desde que a gente começou a namorar ele falou que mulher dele nunca iria trabalhar. Falei 'bom, tudo bem', eu trabalhava, né, perdi o emprego, larguei o serviço por causa dele. Ele é aposentado, ele se aposentou, mas continua trabalhando na mesma firma, ele disse que se parar de trabalhar ele morre. Ele tomava diazepam, ele parou, ele é muito exigente com ele, ele disse que nunca ia tomar mais nada ai parou. O meu marido é exigente com os dois filhos dele, eu falo para parar de implicar com os meninos, ele fala que quer assim do jeito de que quer, na hora que ele quiser, tudo do jeito que ele quer. Oh, se não fazer, oh meu Deus. Ele é filho de português."

Os conflitos internos na casa não ficam restritos a um mundo material, social e familiar, se relaciona com o outro mundo imaterial, como DAMATTA (1997, p. 158) diz, num mundo em que "a morte mata, mas os mortos não morrem", continuando suas relações de poder mesmo depois da morte, fixando-se na memória daqueles que ficam, permanecendo as estruturas de suas relações de poder, destacando a cada dia os seus feitos, seu nome, seus “sacrifícios', seus desejos:

'Nisso é fundamental não perder de vista que o 'morto' é sempre o elemento que deixou o cenário abusiva e abruptamente, mas que ainda mantém um ele potente com os que ficaram (...). Ansiedades acumuladas num espaço podem ser aliviadas noutro e todas podem ser finalmente relativizadas diante do morto e do 'outro mundo', quando todas as esperanças e desejos podem se encontrar de forma perfeitamente equilibrada" (DAMATTA, 1997, p. 158).

O morto aqui não é como o Vadinho, é um morto racionalizador, que já não questiona o mundo burocrático, mas o reafirma, o intensifica. As exigências que se tem sobre seus papéis, sobre seu trabalho tornam-se também transcendentais, por isso as exigências sobre o corpo chegam aos limites de sua existência, de sua força, o sentido de normal é a capacidade de sempre estar nesse limite, nessa condição de 
esforço máximo para ganhar uma futura recompensa devido ao cumprimento dos papéis determinados pela família e socialmente:

"Já tomei mais, acho que nem faz mais efeitos, mas por enquanto estou precisando. Acho que minha aprovação já tá completa, feita (...) tenho lugar no céu, eu quero uma casa bem boa quando chegar lá no céu. (...) A minha mãe me falava, falava assim, nossa, eu brigava com ela por causa disso, ela falava 'oh minha filha se conforma porque eu tô indo embora, oh, se comporta que eu to indo embora', eu falava 'ah mãe o quê que é isso, a senhora está pensando que vai encontrar com o meu pai, não vai não', aí quando ela ficou mesmo doente, ela ficava só na cama, não andava mais sozinha ai eu falei 'ah mãe a senhora sabe que tá acontecendo, sabe mãe cê tá pensando que vai pra rua, o pai que falou que a senhora ficar aqui pra não sair pra rua, oce vai ficar aqui presa comigo', era muito divertido aqui com a minha mãe, o que eu fiz na vida dela, ela teve um final feliz."

A concorrência provocada pela mãe entre as irmãs é vista como parâmetro para avaliação, levando um irmão a se dizer melhor, ou que cuida melhor da mãe. A visita da mãe na casa de outra filha gera ciúme que reforçava atitudes de cuidado e atenção à mãe:

"A minha mãe gostava muito de ficar na minha casa, cê ver o meu marido e meus filhos, eles são um barato, não parece pai e filho, filho brinca com ele, beije ele, então quando a minha mãe ia passar uns dias lá com a minha irmã, ela ficava triste, juntava as coisas e ia embora e nem olhava pra mim, nem falava tchau pra mim, tava triste, mas quando ia buscar ela, ela vinha toda sorridente, falava tchau filha, desculpa (...), desculpa pelo trabalho que eu ti dei... abraçava e despedia. Eu falava ora mãe a senhora daqui quando vai embora abraça, despedi, ela ria."

Outra moradora da parte antiga do bairro, Ivanilda (43 anos, dois filhos), vivendo numa posição liminar, diferente da de Talita, a casa de Ivanilda ficava entre o bairro antigo e o das casas luxuosas, dizendo que quando chegou ali era tudo cana, era um buraco e que sua casa foi adquirida em decorrência das sobras de terrenos dos loteamentos. Ivanilda passa por um processo de consumo de medicamentos psicoativos relacionado também aos filhos e aos cuidados despendidos com os familiares doentes. As dificuldades financeiras e os conflitos com o marido se apresentaram mais intensos do que os relatadas por Talita. Antes de Ivanilda morar ali, disse que morava com os sem-teto, mas que já faziam 7 anos que residia ali. Enquanto a casa de Talita era toda construída, Ivanilda me perguntou se eu sabia de 
alguém que tivesse material de construção sobrando, para lhe dar, pois sua casa quando chovia molhava tudo dentro. Ivanilda mostrou uma relação entre religião e consumo de medicamentos psicoativos, dizendo-me que tomava comprimido branco e verde e havia parado de tomar os medicamentos graças à igreja:

"Não tomo mais, eu parei de tomar porque logo eu comecei a ir na igreja e a última vez que conversei com a psicóloga e ela falou que não resolvia, ele ajudava, que quando der vontade de chorar é pra você cantar, faz uma coisa assim. Ai logo eu comecei a ir na igreja também, aqui na Deus é Amor (...). Ai começou, eu colocava o remédio aqui em cima da geladeira, ou no armário, parecia assim uma coisa, eu não achava, então eu não tomo mais, eu fazia tratamento aqui no núcleo, agora não tomo nenhum mais. (...). Olha, assim oh, deixa eu ver se você entendi, a pessoa quando não conhece a palavra ele (medicamento) ajuda, mas depois que você começa a conhecer, assim, a palavra de Deus, se apega com a ele, aí você acha assim que aquele remédio lá não passava assim, como eu posso dizer, de uma droga, né, daí quanto mais você toma mais se quer, porque, assim, se toma parece que não sara e nem nada (...). Na verdade, eu tinha loucura pra ter um filho, dai eu engravidei, no dia 4 de dezembro vai fazer nove anos que ela faleceu. Aquilo ficou na minha cabeça, não saia, aí eu engravidei de novo, perdi, ai logo eu fiquei grávida dessa minha menina, da Manoela, foi uma maravilha. Aí quando eu fiz a ultra-som que deu menina, ai pronto, eu não aceitava de jeito nenhum. Ai logo o meu irmão ficou doente ai comecei a acompanhar ele no médico, né, então acho que.... Aí ele faleceu, aí logo este aqui nasceu (filho), logo que nasceu ele ficou internado com bronquite, acho que foi juntando tudo. (...). Ela nasceu morta... Eu comecei a usar depois que a minha menina tava com 2 pra 3 anos... era assim, eu tava aqui não tava bom, nada tava bom, nada ... Minha vizinha virou e falou assim pra minha mãe 'ela não tá boa, deve tá com depressão', eu já não ligava mais pra casa, não ligava mais pra ele (filho) (...), chorava 24 horas, então, aí o pai dele pegou e começou aí pegou... Falou 'oh cê só vai ficar com os meninos se você fizer um tratamento, ai pegou... Um dia a minha mãe foi levar eles pra pesar,... Parece que foi a Abadia (agente comunitário de saúde) (...) e uma outra com eles, parece que ela era psicóloga (...), ai fui no núcleo, ai a doutora falou assim 'que tem vários tipos de depressão, a que você tem é a mais agressiva de todas, porque essa é assim, mata uma pessoa brincando '”.

Ivanilda tinha parentes que eram moradores próximos a sua casa, como a sua mãe e uma irmã que havia falecido e era vizinha de casa. A morte de sua irmã e de sua vizinha ocorreram de forma inesperada. Ivanilda me relatou que o sobrinho tinha jogado pedra no carro do outro vizinho, que foi reclamar com a mãe dele, e ao receber o rapaz, a mãe desmaiou e faleceu devido a um aneurisma logo em seguida 
no hospital e que a irmã do menino e o pai não deixam de culpar o menino, e que a sobrinha também tomava medicamentos psicoativos. Disse que o médico havia explicado que ele, o sobrinho, não tinha culpa da morte da mãe, que ela poderia até morrer dormindo. De acordo com Ivanilda, os seus dois sobrinhos ficavam mais na rua, o pai ia para o bar e os dois meninos ficavam sós, e para Ivanilda eles ficaram órfãos de pai e mãe. A necessidade de se transformar na cuidadora do irmão devido a mãe não estar bem para exercer essa função foi relatada como relacionada ao consumo de medicamentos psicoativos, somando-se às dificuldades econômicas:

"O irmão faleceu, ele tinha câncer na garganta, ele teve que colocar um aparelho (...) éramos em cinco irmãos, agora ficou três. (...) O meu pai tinha essa doença, esse meu irmão deu nele também, só que ele também dava crise epilética. Aí eu falei que não ia dar para cuidar do Roberval (irmão que morreu) e da menina (sua filha pequena) ao mesmo tempo (...) Falaram que eu tinha que parar de trabalhar (...), ai comecei a acompanhar ele nos hospitais, nos médicos, daí a cabeça da minha mãe já não ajudava mais, a minha mãe tá com 67 anos, parece, uma coisa assim... Aí ela ficava com minha menina e eu ficava no hospital com meu irmão. Não chegou a um ano certo, porque teve um dia ele parou de comer, ele falava que a garganta doía. Eu falei 'vamos no CSE que você deve tá com a garganta inflamada, aí o médico disse que era apenas um resfriado, ai o médico da rua carioca disse que ele tava com problema de estômago, ai deu remédio pra úlcera, não tinha nada a ver, aí ele foi um dia cedo, eu fui lá conversar com o médico ai eu falei 'pelo amor de Deus interna ele que ele não tá bom, ai falou cadê ele, ai eu falei 'como é que eu vou trazer ele, se lá de casa aqui no ônibus, eu não agüento segurar ele, eu não agüento, e isso eu tava grávida dele (filho) e eu não sabia, aí vou dou um jeito... aí foi a minha mãe e minha irmã que levou ele, encaminharam ele pras clinicas, ai pego o médico ainda ficou brabo com elas, porque não tinha levado ele antes, ai minha mãe falou que o médico, o médico explicou pra ela, que 'oh, ele tá com câncer, aí parece que deu um nó na cabeça dela, a cabeça dela não ajudava nem a pau."

Além das mortes dos irmãos, Ivanilda disse sobre seu relacionamento com o marido, revelando a associação entre violência doméstica e consumo de medicamentos psicoativos. Ivanilda e o marido, mesmo separados, ficaram morando na mesma casa, e segundo ela, o marido só saiu da casa com a intervenção do juiz: “ele é uma pessoa que não respeita ninguém, tem a boca muito suja, não respeita ninguém, então é por isso que eu não dou certo, várias vezes ele me agrediu”. 
Olga (viúva, 67 anos, casa localizada no bairro antigo) também me relatou sobre as dificuldades sobre o cuidar dos entes familiares que adoeceram. O que se vai juntando como motivo para o consumo de medicamentos psicoativos é destacado também aqui, primeiro a morte do marido e depois de sua filha. Ao mesmo tempo em que valorizava o trabalho do Núcleo de Saúde da Família, reclamava dos médicos que não foram a sua casa quando chamaram, mostrando que o serviço passava por uma exigência aqui nessa parte do bairro e não de uma recusa. Os serviços de saúde mostraram através dessa entrevistada uma flexibilidade do uso dos medicamentos. Olga me disse que depois da morte do marido, que já faziam sete anos, também tomou os medicamentos. A prescrição admite uma relação direta com o cotidiano: "Foi que eu fiquei muito agitada com a falta da menina, daí passei com o médico do coração, lá do CSE e aí ele me receitou, ele viu que eu não tava dormindo, então ele falou então toma, o dia que você tá bem não toma, o dia que não, toma."

Olga, ao acompanhar o tratamento de sua filha, aprende sobre os efeitos dos medicamentos. Os cuidados com a filha se misturam com o cuidar de si, analisando o estado de seu próprio corpo para perceber as condições necessárias:

"dela eu pegava o neozine (...).Ela andava, falava, comia sozinha, normal, conversava normal (...) Nunca deixei ela sozinha, nem ir no portão (...). Ela ficou quase 20 anos na APAE de São Paulo (...). A fluoxetina eu larguei, comecei a tomar me deu dor no estômago, perdia a vontade de comer (...) com o diazepam eles não querem mais prescrever, mas aqui se eu pedir eles não dão mais, eu tem que pedir pro outro médico (...), eu tomo quando eu fico muito agitada, já faz um tempo que eu não tomo (...), agora eu tô voltando a não dormir de novo, eu evito."

O outro doente passa a servir de medidor de seu estado, o dar conta de cuidar do outro controlando o significado de competência e o de ser saudável. A filha, pessoa com deficiência mental, necessitou durante sua vida dos cuidados da mãe e outros acontecimentos envolvendo a função de cuidar foram se juntando, como o fato do marido adoecer com câncer e ficar seis meses em tratamento, como sua irmã que também havia falecido de câncer. A casa se transformava em lócus para o acompanhamento de doentes, vindo parentes de outras cidades para seguirem o tratamento em Ribeirão Preto por considerarem ali lugar privilegiado em relação à 
assistência médica-hospitalar. A família era moradora da cidade de São Paulo, mas originária de Ribeirão Preto, depois de o marido trabalhar e aposentar em São Paulo resolveram voltar para Ribeirão Preto, reafirmando o sentido de lar natal como referência para sua vida, do trabalhar e voltar em condições financeiras melhores do que a de quando partiu:

"aí a gente voltou, ele veio pra ver o serviço (...). Eu perguntei se ele gostou do serviço, ele falou que ia ficar, que ia vender o apartamento e comprar uma casa aqui (...). Quando ficou 6 meses, deu câncer na coluna dele e parou de trabalhar e dai morreu (...), parece que tava adivinhando, ele foi nascido e criado aqui (...). Lá (em São Paulo) se eu tivesse com a menina tinha sido pior pra mim, aqui eu tinha os médicos toda a hora foi mais calmo pra mim cuidar dela e tudo (...). Meu marido não tinha nada, a outra minha irmã que faleceu aqui, veio de São Paulo e faleceu aqui comigo, tratou seis anos aqui (...). 40 anos eu cuidei dela (filha), eu dava banho, cuidava, trocava, dava comida, ela ficava ruim eu corria pro médico, pro hospital, a vida, a dedicação com ela, né... Ela tava bem, no domingo ela passava bem, comeu, dormiu, brincou com o meu neto, ela gostava de brincar com ele, ouviu música. Tinha nada no domingo, nada, nada, nada, dai ela tomou banho e de tarde, pus lá na cama, fui tirar ela da cama (...), ela botava xixi, eu punha fralda, dai eu tirava ela da cama e ia dar banho, chamei ela, daí quando eu tirei ela da cama ela vomitou, aquele negócio, aquele negócio, chamei os médicos das clínicas, dei um banho depressa nela e aí ficou, por fim eles me falaram que era uma pneumonia seca, que eu não sei o que é isso (...), dai os médicos das clínicas começou, o pessoal das clínicas, fuça lá, corta aqui, aí cortaram aqui (mostrou o pescoço) e foi aquele negócio, ali começou, começou inchar as pernas dela, paralisou o rim, ai quiserem que ela fizesse hemodiálise, mas não conseguiram fazer, ai foi indo... Fez dois meses que ela faleceu."

Quando perguntei sobre o bairro e os vizinhos, ela me disse que eram todos bons, inclusive o pessoal da favela, mas se notava através da fala que carregava um estereótipo, servindo o termo "guerra das favelas" como referência para definir sobre os tempos violentos. A existência de uma moral predeterminada como modelo é imposta para todos, indo desde o vizinho até os trabalhadores dos serviços de saúde, afirmando um modelo, um estilo de vida concebido como correto:

"O pessoal da favela não atrapalha em nada, faz oito anos que moro aqui ele nunca mexeram em nada, pelo contrário, se eles percebem que tem alguém mexendo eles vão atrás (...) o começo que eu vim para cá, tinha a guerra, ai davam tiroteio, fumam mas não mexem aqui... Tem um rapaz que tinha tudo aqui e tava cheio de droga, uma casa de família (...) Eles (moradores da 
favela) são tranqüilos, não podem e mexer com eles (...) Eu tenho uma faxineira que mora lá ainda, nunca mexeu num lápis (...). Muita gente não parece médico, todos os médicos que tava atendendo era arrumadinho, um jaleco impecável, um médico sujo, um jaleco sujo, a calça jeans sujo, barra suja... olhava nele nele assim... quando for um médico assim, no posto de saúde deve ser limpo (...) tem muito gente da favela que vai bem arrumada. Tem casa da favela que você entra que tem aparelhagem de tudo quanto é jeito (...). Sabe a Juliana (agente comunitário de saúde), ela mora na favela e é uma graça, mora na favela e é um amor de pessoa, uma graça, nossa, limpíssima, o marido dela, a casa é limpinha e mora na favela."

Nessa parte antiga do bairro observam-se vários estudantes e residentes ali. Estes também não deixam de ser avaliados, como Olga me disse que tem uma vizinha que trabalha no campus da USP, sendo uma vizinha profissional da saúde que trabalhava também no Hospital das Clínicas e que a ajudava a cuidar da filha. Além disso, sua casa, por ficar perto dos serviços de saúde, era mais acessível a uma maior rapidez da presença dos profissionais de saúde: “depois que o meu marido faleceu, assim, ela não agüentava ficar sozinha, ela caia, igual a um ataque epilético, ai o primeiro lugar que eu chamava era eles (núcleo), dai eles vinham correndo, vinha o médico e a agente, me ajudavam, socorria tudo, quando eles achavam que tava demais ai eu ia embora pro hospital (...)”,

Contudo, Olga reclamou das demoras dos serviços de saúde e de um médico que não compareceu quando foi chamado. Olga se casou aos 19 anos com um metalúrgico que foi para São Paulo, deixando para lá uma filha e três netos. Uma outra filha, moradora da cidade de Ribeirão Preto que participou de parte da entrevista também tomava antidepressivos e durante a entrevista chegou uma outra vizinha que me disse que também tomava antidepressivo. Além disso, me relatou que ali naquela mesma rua existiam outras pessoas que consumiam antidepressivos.

Essa parte do bairro mostrou uma maior presença dos serviços de saúde, sendo observado que alguns fatores colaboram para esta maior proximidade, como uma equivalência relativa ao habitus. O habitus é visto como promotor de identificação e compatibilidade, evitando conflitos quando se tem mutuamente ideais semelhantes, colaborando para impor modelos de comportamentos, modelos de famílias que nem sempre correspondem à realidade, ignorando a diversidade de 
modos de vida e impondo os exemplos de famílias consideradas ideais (FONSECA, 2005). É bom lembrar que a imposição de um modelo pertencente a determinado grupo social aos outros grupos gera conflitos e insatisfações, conflitos estes que podem ser medicalizados.

As situações que são ditas comuns passam a ser facilitadoras do consumo de medicamentos psicoativos, associando sintoma e vida cotidiana. Quando o casal reconhece que vive seu dia-a-dia de forma estressante, pode surgir o empréstimo de medicamentos entre esposa e marido. Uma entrevistada do bairro antigo me disse que usou por um período muito curto o antidepressivo, não chegando a utilizar o ansiolítico, mas que ocorreu de o marido começar a consumir seus medicamentos. $\mathrm{O}$ casal se transforma em lócus de troca de experiência sobre os medicamentos, "auxiliando" o consumo de medicamentos:

"ah, eu tomei porque eu tava me sentindo assim... Eu conversei com o médico e ele disse 'oh a senhora deve estar com começo de depressão', mas o que é mais é a correria do dia-a-dia. Tirar férias porque eu trabalho de telefonista, é um serviço bem estressante. Oh pra te falar a verdade eu comecei tomando, aí eu não me sentia muito legal com ele não, sabe, eu comecei a ver que ele me dava muita fome, ai eu comecei usar um dia sim, um dia não, ai depois disso eu parei de vez, eu não usei nem um mês, parei por conta própria mesmo. Meu serviço é muito estressante eu passo muito nervoso, serviço me deixa muito agitada... Ah, eu sentia uma fome, um vazio no estômago, aí eu falei que não ia tomar isso não, parece que tava ficando mais ansiosa, mas ao mesmo tempo me tirava aquela agonia, aquele nervoso. Mas parece que às vezes ficava mais ansiosa, mas tirava a agonia, aquele nervoso... No fim das contas ele (esposo) começou a tomar. (...) Ele começou a tomar fluoxetina porque, dai ele falava 'pega no posto, não deixa de pegar no posto', sabe, dai eu pegava às vezes no posto, não deixava de pegar (...). Ele também parou de tomar... Eu, não chegou nem um mês, senti melhora, até um pouco menos estressada... Ele tomou o quanto tinha, acho que foi uns três meses, o quanto que teve (...). A gente vai tirar as férias e na hora resolve pegar o dinheiro e fica mais um ano sem férias, dai fica estressado, foi ai que precisei (...) Eu estava comentando com a minha vizinha e falei que não me adaptei com a fluoxetina". 
Diferente de Olga que casou e foi para a cidade de São Paulo, sendo dona-decasa, entrevistei outra moradora da parte antiga do bairro, uma senhora de 72 anos,

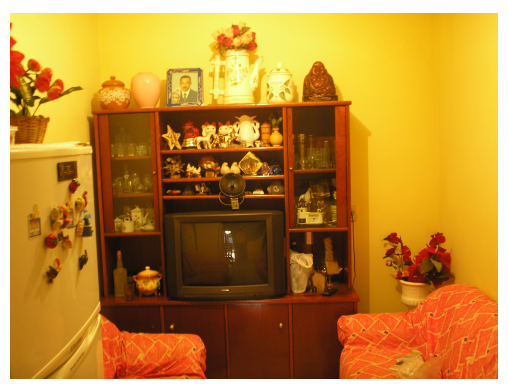
chamada aqui de Paula. Nascida no Estado de Minas Gerais, Paula morava nos fundos da casa de sua irmã, mas já tinha morado na cidade de São Paulo por 32 anos, voltando de lá havia apenas 3 anos. Paula falou sobre seu estado de saúde, a dificuldade de andar, de falar, enxergar. Em São Paulo trabalhou na área de esterilização. O passado em Paula parece que aflora a palavra "saudade", mesmo no que não se lembra, como de sua mãe que morreu quando Paula era muito pequena, sendo criada por seu pai e pela madrasta. Paula vê na velhice um mau presságio que deve ser evitado: "não quero dar trabalho pros

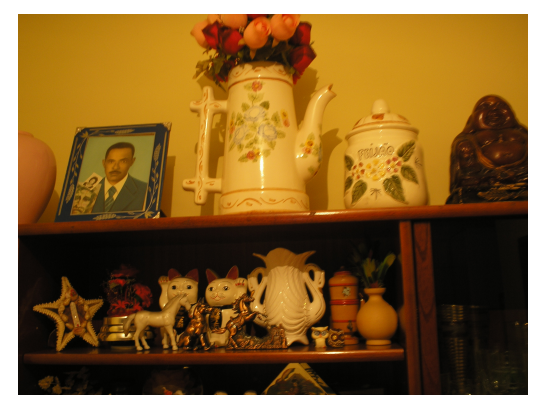
outros não". Paula me fala de morte, morte dos irmãos, morte dos pais, morte das amigas, do namorado:

"Tive vontade de trabalhar fora e meu pai nunca deixou, dai quando o meu pai faleceu eu fui pra São Paulo (...), foi uma moça que me levou, ela já faleceu, coitada (...). Meu pai era lavrador, morava na fazenda, fazenda do meu pai, morava com minha madrasta (...). Quando morrem (os pais) esparrama tudo, então, eu fui pra São Paulo (...). Naquele tempo não precisava de estudo pra trabalhar, agora precisa, antes era aprender o serviço e pronto, hoje precisa de estudo pra trabalhar, quem não é formado não consegui serviço (...). Os medicamentos fazem pouco tempo, não tomo todo dia não, é uma vez ou outro. Eles acharam que eu tava com depressão, é um calmante, eu sou depressiva (...), quando eu não tomo eu fico desanimada, com as pernas mole, dai eu não consigo andar direito (...). Trabalhava na roça, tudo na enxada, 6 homens e 7 mulheres, tem 4 mortos... Morreu 2 homens e duas mulheres (...). Nunca casei, mas namorar eu namorei muito (,,,) Eu acho que é sorte, lá (Minas Gerais) eu tinha namorada lá, tive paixão que ficou pra trás, o moço que eu namorava eu gostava muito dele morreu de Aids (...), quando ele morreu eu não namorava ele mais, tinha 22 anos. Ele vinha também pra São Paulo, eu não deixei. Foi na época que eu fui pra São Paulo, tinha uma mulher lá e disse que tinha 3 filhos e era dele (...) Ele foi um dos primeiros (a morrer com AIDS), foi no tempo que achava que pegava, ele ficou em uma casa separada, antigamente eles achava que até o câncer pegava. Ele disse que não podia casar, eu falei 
'não vou arrumar homem enrolado pra minha vida não, não’ (...). Naquela época só namorava, só namorava, não era igual hoje com sexo (...), naquele tempo os pais colocava a gente pra fora de casa, os pais ficavam muito brabo, nossa senhora."

Paula me relatou que teve vontade de casar, mas que era muito exigente e sempre gostou de ser livre, sendo que o casamento significaria uma prisão para sua vida. Paula disse que ainda namorava, mas casar seria uma condição ruim para as mulheres devido aos afazeres domésticos somarem-se com outros trabalhos:

"Lá em São Paulo arrumei namorado... eu fui muito... vacilava muito, sabe, eu era assim, arrumava namorado e se ele falava assim que vou em tal dia e em tal hora, se ele não viesse não precisa vir mais, fui por isso que eu não casei. O de Minas eu gostava muito dele, ele era o primeiro homem que eu gostava muito, né. Mas, o casamento é uma prisão ao mesmo tempo, casa e aí logo vem os filhos, né.... não tem condições... O homem quando chega do trabalho toma um banho, vai dormir ou sai, né, a mulher chega, tem que fazer tudo, tem que fazer janta, limpar casa, então a vida do homem é bem mais fácil, no casal.(...) Um moco feito, bem criado é dificil encontrar em São Paulo, lá tem muita coroa bonita, bem tratada... lá tinha os bailes, tinha um pessoal bonito. Aqui, eu fui num, só tinha bagaceira (...). Até aos 68 anos eu tinha namorado, namorei 2 anos, dai eu vim pra cá, e ele foi embora pra Bahia. Ele era mais novo que eu 12 anos... Eu gostava dele."

Paula me descreve que primeiro começou o tratamento no Núcleo, sendo depois encaminhada para a psiquiatria e que no momento fazia tratamento novamente no Núcleo de Saúde da Família. Acerca dos serviço de saúde, disse sobre a presença dos estudantes, do uso da população para aprender a profíssão. Além disso, Paulo nota que ocorre uma homogeneização dos pacientes e das prescrições dos medicamentos:

"Tem muita gente e aqui trabalha os estudantes das clinicas, os estudantes, acho que por isso parece que eles ficam sem saber o que faz, num formo ainda, ficam sem saber (...). Eles dão receita pra gente (...), parece que tá todo mundo tomando o mesmo remédio, todo mundo tomando o mesmo remédio. Será que todos têm a mesma doença? O povo tá tudo com a mesma doença? (...). Em São Paulo era melhor, aqui é só estudante, vai um dia é, vai outro é outro, então o médico nunca fica por dentro do que tá acontecendo com a gente. (...). Igual a minha irmã, 'eu falei que se for acompanhar esses médicos eu não vou comer mais, os remédios me enchem' (...), hoje tudo é com remédio, prescrevem o remédio mas não sabe o que tem, o que esta acontecendo. Ficam indecisos sem saber o que faz, se ficar 
doente, pode ir lá quatro ou cinco vez, eles dá o mesmo remédio, tem aquela filona, assim o povo vai chegando, chegando."

Devido a um passado tão presente na vida de Paula, os medicamentos psicoativos são vistos como ordenadores desse passado, de sua memória. Quando perguntei sobre o que ela supunha que tinha causado o consumo dos medicamentos, ela me disse que trabalho não era, pois este fazia bem e que os medicamentos "ajuda mais aos anos de vida que passou do que vai vir". De acordo com Paula, ela tomava de vez em quando o ansiolítico diazepam, mas o antidepressivo utilizava todo dia, relacionando os efeitos dos medicamentos com o cansaço: "Os remédios diminuem a canseira, a dor, né, até os 60 não tinha nada, depois dos 60 que a coisa despencou (...). Eles acharam que eu tava com depressão, me deu um negócio, não enxergava, não conseguia andar, ficava ansiosa, com muita ansiedade, daí me deram esse remédio pra mim tomar."

Paula mostra-me suas lembranças através das fotos colocadas em lugar visível de sua casa, fixando suas lembranças, ordenando suas origens com o presente. O curso de sua vida segue por algumas de suas lembranças, como foi a entrevista, alguns acontecimentos falados, outros escondidos, privados, outros esquecidos, e outros "esquecidos" somente por alguns instantes da vida. O fato de não ter casado justificava ali sua solidão, sua culpa por não ter sido mais flexível com seus namorados, criando uma velhice particular. Paula às vezes se aproxima de uma velhice triste e solitária ao mesmo tempo em que sua velhice resiste ao corpo, uma velhice que festeja os anos, festeja os fatos não ocorridos, sente-se livre, não está presa a outro, Paula se transforma no que MOTTA (1998) chamou de "velhice faceira", caracterizada pela presença em bailes, pelas vaidades com o corpo, pela jocosidade, pela sexualidade, pela alegria dos encontros com outros "velhos", revelando particularidades de sua geração, dos comportamentos não aceitos, pela vontade de voltar no tempo e viver novamente.

Diferente de Olga, que foi casada e teve filhos, formando um comportamento voltado para o cuidado com os filhos e o marido, Paula criou laços de amizade no local em que teve maior liberdade, São Paulo, tendo vários namorados no decorrer de 
sua vida, participando de bailes. Contudo, a "faceirice" de Paula foi transformada quando foi morar em Ribeirão Preto, mais perto dos familiares, deixando Paula com saudades das festas e dos laços de amizade de São Paulo. Tive dificuldade de encontrar Paula em sua casa, que ficava nos fundos da casa de uma irmã, estando na casa de sua irmã ou de uma amiga, enquanto Olga estava lá presente, ficando mais restrita a sua casa. Paula aproxima-se mais das "velhas faceiras" de MOTTA (1998), fazendo destacar-se por fugir a norma de uma velhice previamente determinada como frágil, restrita ao lar, sem vaidades para as festas, porém, os sintomas de sua fragilidade, de seu deslocamento de São Paulo, fazem-na perder sua "faceirice", iniciando o consumo de medicamentos psicoativos depois que fora para Ribeirão Preto. Enquanto que o verbo de Paula é "perder", perder os amigos, os namorados, as destrezas do corpo, o verbo de Olga é “juntar”, é a soma de acontecimentos internos ao lar que colaboram para o consumo de medicamentos psicoativos, da doença da filha, do marido, entre outras, fazendo da morte não uma perda, mas um acontecimento que se junta à vida de Olga. O marido de Olga não morre, permanece vivo na memória construída na família, no lar. Paula não tem casa, não teve também em São Paulo, vivia lá em um quarto de pensão, inicialmente com uma amiga que tinha ido com ela, depois que a perdeu devido a sua morte, Paula passou a viver sozinha e continuava vivendo só. Olga estava rodeada de parentes, fazendo os acontecimentos passados serem coletivamente lembrados, reafirmando-os constantemente pela família.

Para as mulheres aqui entrevistadas, o trabalho doméstico foi visto como determinante para o consumo de medicamentos psicoativos, sendo intensificado pelos acréscimos de serviços que ocorreram no decorrer da vida dessas mulheres, como o surgimento de um familiar doente para cuidar. Além disso, muitas mulheres possuíam outros trabalhos fora de suas casas, podendo ser uma extensão dos seus afazeres na sua própria casa, como lavar, passar, cozinhar, cuidar de doentes, crianças, etc. O verbo "juntar" aqui se alia ao "movimentar-se", juntar trabalhos não reconhecidos, não remunerados, exigindo maiores movimentos do corpo. É movimentar-se em busca de empregos, para acompanhar o marido, para fugir de 
normas impostas que fazem da mulher prisioneira de suas origens familiares. A saída de casa da cidade natal, como aconteceu com Olga e Paula, é permitida mediante autorização do pai, Olga através do casamento, Paula acontecendo somente após a morte do pai. Ambas foram para São Paulo e possuindo um curso de vida particular, origens socioculturais diferentes que possivelmente interferiram no consumo de medicamentos psicoativos, mas que seriam homogeneizadas pelos serviços de saúde. A casa passa a ser, além de um lugar de conforto que demanda trabalho, um lugar de referência sociocultural, representando gostos, desenvolvimento financeiro, higiene, vitória, uma prisão ou uma liberdade. Ter a casa própria é fundir o tempo ao espaço, é se fixar em um lugar através das relações com os outros, formando diálogos.

\subsubsection{Mudando de bairro, a casa dos sonhos}

No caminho em direção às casas $\mathrm{COHAB}$, passei pela rua que dividia a favela do bairro das casas luxuosas e entrevistei Silvia, uma mulher de 71 anos, vinda de Minas Gerais com seu marido, tendo um filho que morava com ela. Silvia foi entrevistada tendo no fundo o som de um culto religioso pelo rádio, estava fazendo o jantar mais cedo porque iria a sua igreja mais tarde. Silvia, viúva há 20 anos, morava com seu único filho, um rapaz que já tinha visto com um carrinho de mão juntando material para reciclagem, papel e garrafas de plásticos. Silvia nasceu em outra cidade do interior paulista, de origem rural, em uma cidade menor do que Ribeirão Preto, casou e mudou para Ribeirão Preto em busca de melhores condições de vida e ali ficou, contando os anos que passaram e justificando inicialmente que foram eles que a fizeram tomar os medicamentos. Mas o desenrolar do tempo foi revelando o que complementava esses anos que passaram, as mortes dos filhos, as tristezas, os sonhos não realizados, as dificuldades financeiras, a vontade de ter uma boa casa: 
"A saúde da gente enfraquece um pouco, né, ela muda um pouco, muda bastante, até os cinqüenta eu não sentia nada, eu sou assim, tinha uma disposição, sabe, pra trabalhar, disposição era ótima, mas depois dos 50 aí vem muita coisa, vem menopausa, menopausa é uma tristeza, ela acaba com a gente, se não tiver tratamento dai talvez vem até depressão, entendeu (...). Ai depois dos sessenta piorou mais ainda, ai eu fiquei com aquela depressão, eu não tinha ânimo pra fazer nada, não tinha vontade nem de deitar, cê entendeu (...), o sol não brilhava pra mim, parecia que tava no escuro, eu não tinha vontade de viver, a minha vida acabou. Eu tinha medo assim, não tinha medo de morrer mas tinha medo de deixar o meu filho, ele ia ficar na mão dos outros, porque eu pensava se eu morrer ficava, ele é doente, tem problema de bexiga, mora comigo (...), eles até operaram, mas não resolveu, em um mês voltou tudo de novo (...), ele urinava toda hora, ele não pode trabalhar em serviço registrado, porque nunca trabalhou (...), ele trabalhou uma vez só, ele tinha 13 anos, o pai dele era vivo ainda (...), tive mais, tive 3 filhos, quatro com ele, os outros morreram, um morreu com 15 dias, um morreu com 20 dias, o outro morreu com oito dias, foi assim, sabe."

Silvia mostrou que o passar dos anos se concentra no juntar acontecimentos, tentar um novo projeto não é cogitado, como casar novamente: “não vou casar de novo, às vezes não dá certo, caçar sarna pra coçar”. A escabiose, popularmente conhecida como sarna, é uma doença que provoca um prurido que incomoda muito, e no sentido dado por Silvia um mau marido se assemelharia a esta doença.

Silvia foi contando os fatos de sua vida, disse que já tinha tido antes um pouco de insônia:

"Às vezes era com qualquer coisinha, se eu passasse muito nervoso, se eu preocupasse com alguma coisa eu perdia o sono. Eu tive depressão quando eu tive esse menino, esse rapaizinho (filho de 40 anos), fiquei com depressão, eu tava de resguardo dele, sabe, foi dessa época pra cá que eu fiquei assim (...). Eu tava ouvindo o médico falar que as pessoas que tem depressão passa, ela fica até 5 anos, mas a depressão volta. Quando eu era nova eu achava que tinha, assim, era um começo. Eu não gostava assim, eu não sabia porque tinha aquilo."

A casa de Silvia ficava a poucos metros da avenida que dividia com o bairro luxuoso, fazendo cinco anos que morava ali, tendo duas sobrinhas que moravam perto, na favela. Silvia considerava ali um lugar estratégico, a proximidade com os serviços de saúde facilitava suas idas e vindas para as consultas médicas. Além disso, os serviços dali, por serem considerados de referência, possibilitavam a Silvia dizer 
que tinha os melhores tratamentos, quando comparados a outros lugares ou regiões.

Além disso, a relação com o rural e as menores cidades eram vistas como atraso científico em comparação com as grandes cidades, levando Silvia a se sentir privilegiada por morar em Ribeirão Preto:

"Casei com quinze anos, continuei morando na roça, aí surgiu aquela época que os fazendeiros, eles num quis mais os colonos, né, pra trabalhar, ai então viemo pra cidade, ficamos na cidade. Fui morar numa cidade pequena, numa cidadezinha (...). Já me deu vontade de voltar pra lá só que lá não é uma cidade que tem recurso igual aqui, igual Ribeirão (...) área de saúde é bem melhor, o hospital, vem gente de tão longe, né (...). Hoje eu tava pensando, nossa, fui lá, cheguei lá as 7 horas, sai daqui, fiquei lá até nove, nove horas eu fui atendida, é muita gente, né? Quando entrei lá tava assim, não tinha nem lugar pra sentar. É muita gente, nossa... tem gente de tudo quanto é jeito. (...). Eu gosto daqui, né, um lugarzinho bom assim porque é perto das clínicas. Hoje mesmo eu tive lá, nas clínicas, tirar sangue porque, fui colher sangue, o médico pediu para colher sangue 15 dias antes do retorno, eu tenho retorno agora, porque eu ver se tem anemia, porque eu não comi direito, né, num alimentava, porque tão achando que tenho anemia".

Fazendo uma comparação entre a igreja e os serviços de saúde, Silvia preferia ir à igreja do centro da cidade, mesmo existindo outras iguais perto de sua casa. A igreja se fundia aos medicamentos, a melhora dos sintomas muitas vezes se transformava numa conquista através da fé, levando a dois tipos de "acompanhamentos", um através da igreja, o outro através dos serviços de saúde, ambos interferindo nas ações de Silvia sobre o modo de usar os medicamentos:

"Eu acho que igreja ajuda, o remédio ajuda um pouquinho, né, ele ajuda, a gente dorme, descansa o cérebro, né, e a igreja, a igreja é bom porque a gente ta lá a gente vai pedi a Deus, né, ajuda muito sim (...) da outra vez (...) quando eu tive depressão eu tive que tomar remédio, cápsula pra relaxar, daqui do núcleo mesmo, porque aquilo que eu comecei a tomar e me deu diarréia e dor, entendeu, dai eu falei pra médica do núcleo, ela é muito boazinha, tadinha, ela até foi embora, ai eu parei o remédio, dai ela ficou braba comigo, falou que sem ordem do médico não pode parar não. Tava me fazendo mal, eu ia continuar a tomar? Me deu diarréia e muita dor, dor no intestino, parei de tomar, aí depois eu com aquilo comecei a ir na igreja, daí fui indo, fui indo daí sumiu, e agora esse ano comecei a usar outra vez. Faço a consulta no núcleo, eu tomo só a metade dele, eu tava tomando um inteiro, dai me deu muita moleza. (...). Eu continuo tomando porque os médicos pediram pra tomar até o dia do retorno, eu queria parar por minha conta, mas as médicas, as enfermeiras do núcleo disseram 'a senhora não pode 
parar não, senhora só pode parar com ordem do médico', eu falei que tava boa, ai elas falaram que 'sem ordem do médico a senhora não pode parar' (...), eu parei outras vezes".

O cérebro se impõe através da ciência as anulações da subjetividade humana, o corpo se biologiza e a relação biológica medicamento/corpo-cérebro tende a prevalecer frente às questões sociais. O cérebro para Silvia, ou a cabeça (como disse Dagoberto), são colocados como separados do corpo. O medicamento passa a cuidar da química do cérebro enquanto a igreja trata de sua espiritualidade. A relação entre química e subjetividade se torna assim alvo de propagandas sobre medicamentos antidepressivos e ansiolíticos, relacionando vida cotidiana e química do cérebro. De acordo com AZIZE (2008), o cérebro vem tendo destaque na mídia (programas de televisão, revistas populares e cientificas) em relação ao restante do corpo, levando à divulgação de propagandas de tecnologias relacionadas à sua atividade, enfatizando doenças como ansiedade e depressão. O autor relata a existência de grupos de pessoas como as comunidades virtuais discutindo sobre a depressão e ansiedade e a diversidade de revistas tanto no meio acadêmico como popular sobre o cérebro e sua química, mostrando que os medicamentos psicoativos como ansiolíticos e antidepressivos se distanciam como tratamentos para doenças e se aproximam de busca de estados, sensações. AZIZE (2008) ainda destaca as "sutilezas" prócomerciais nas propagandas de medicamentos psicoativos fornecidas pela indústria farmacêutica, uma mescla de paisagens ou ilustrações bucólicas, paradisíacas, conotando uma espécie de "liberdade e paz de espírito", autonomia e lazer, ao mesmo tempo em que relacionam os desajustes químicos do cérebro, levando a estabelecer um novo estatuto do que é considerado normal que, para isso, lá estão os medicamentos psicoativos.

A tênue divisão entre doença e estado do corpo considerado não-doente ou moralmente "doente" é também discutida por AGUIAR (2004), que demonstra que, ao serem proibidas as propagandas de medicamentos psicoativos pelos órgãos governamentais, as indústrias popularizam as doenças, induzindo a diagnósticos e à popularização de medicamentos antidepressivos e ansiolíticos, contribuindo para que doenças como a depressão sejam vistas na atualidade como uma epidemia. AGUIAR 
(2004) diz sobre a fragilidade médica frente à propaganda, comunicando que só basta que seja lançado um antidepressivo com propriedades ansiolíticas que a medicina passará a notar a ansiedade nos pacientes e a diagnosticá-la, levando os medicamentos psicoativos a se tornarem espécie de marcadores para as doenças, os efeitos dos medicamentos passam a definir os diagnósticos. AGUIAR (2004) conclui que a falta de definições precisas sobre as perturbações mentais por parte da medicina possibilita que os medicamentos psicoativos sejam vistos como um projeto de disseminação ilimitada, tornando a sua produção ascendentemente lucrativa. $\mathrm{O}$ mercado farmacêutico aproveita tanto da imprecisão médica como da subjetividade humana para objetivar seus lucros. PIGNARRE (2003) relata o aumento da venda de antidepressivos como parte de estratégias da indústria farmacêutica de divulgação da depressão e de propagação de uma imagem dos antidepressivos como inofensivos e sem muitos efeitos colaterais, contribuindo para que os diagnósticos de depressão aumentassem em sete vezes na França entre 1970 e 1996.

Os medicamentos psicoativos apresentam embalagens diferentes, sendo que os ansiolíticos se diferenciam por apresentarem tarja preta, diferentemente dos antidepressivos, que se confundem com a maioria dos medicamentos com tarja vermelha. Acredito que isso colabore para que os antidepressivos sejam vistos como medicamentos de poucos efeitos colaterais quando comparados aos ansiolíticos. Algumas das entrevistadas falaram sobre o medo dos efeitos dos medicamentos ansiolíticos, parando de tomá-los ou tomando-os esporadicamente, consumindo somente os antidepressivos. Estes foram utilizados com mais freqüência, sendo vistos como "leves", promotores de liberdades, enquanto os ansiolíticos, por causarem dependência, foram vistos como "drogas", "medicamento que dopa".

As propagandas de medicamentos psicoativos, ao unirem efeitos farmacológicos com sentimentos, permitem que o diagnóstico seja subjetivado. Os sentimentos das pessoas passam por um processo de tecnicização ou farmaceuticalização.

Os serviços de maior complexidade foram mais valorizados em decorrência de uma espécie de hierarquia de técnicas, tendo a prescrição de medicamentos como 
o objetivo para resolver os problemas de saúde de forma instantânea. Assim, os medicamentos são vistos como técnicas mágicas e os serviços de maior complexidade como produtores dessas técnicas e por isso mais resolutivos, provocando um menor destaque dos serviços da atenção primária ao serem vistos pela comunidade, nesse sentido, como de pouca utilidade, como mostrou Silvia:

"você sabe que pra mim... eu não tenho muito fé com isso não, sei lá, às vezes se for uma coisinha assim simples, né, mas se for uma coisa mais séria... (...). Surgiu uma afta na minha boca e aquilo tava me incomodando, dai tirei a dentadura, dai quando foi cedo molhei a boca e aí saiu sangue, aquilo me preocupou. Eu ia no CSE, mas como a gente mora aqui tem que passar lá (núcleo) primeiro. A dentista do núcleo olhou, me receitou um remédio e foi bom, sabe (...). O CSE resolve mais."

Além de trabalhar na zona rural, Silvia, naquele momento já aposentada, quando mudou para a cidade trabalhou como doméstica, "limpando chão, lanchonete, restaurante". O trabalho para Silvia estava vinculado a sua saúde, mas não como descrito por alguns dos homens que entrevistei. O trabalho para Silvia significa distração, é a falta de trabalho que faz a doença e não o contrário. A função do trabalho é imposta ao homem, ao seu marido, ao filho, é ele que é insuficiente, não conseguindo uma vida melhor para sua família, ela se vê como vítima da ineficiência do marido para ganhar dinheiro, pelo seu pouco desempenho. O casamento para Silvia, que poderia significar um conforto em busca de melhores condições de vida, da aquisição de uma boa casa, transforma-se em uma ideal, mas o marido, ao não conseguir cumprir esse ideal, passa a ter sua utilidade questionada, sendo representado como insuficiente devido às dificuldades econômicas sofridas:

"Mas a gente pára de trabalhar fica mais doente, com trabalho a gente distrai, esqueci (...). É melhor porque a gente distrai, se a gente fica em casa, só fica pensando naquilo, se a gente vai trabalhar, esqueci, vai melhorando (...). Eu acho que adoeci pelas dificuldades que a gente passou, já vem de quando a gente é mais nova, dai o que acontece na vida da gente, as coisas, aquilo forma uma tristeza na vida da gente, porque a gente passou muita raiva, falta das coisas, meu marido, sabe, ele era assim, ele não ligava muito pra paçoca não, assim ele não bebia, assim ele não tinha uma... faltava muita coisa, a gente não tinha uma casa, de ele dá uma vida melhor pra gente, de dá um conforto (...). Ai vem vindo, vem ficando pior porque na minha família não temo ninguém que tem (depressão), só eu, entendeu, só eu, Conforme o tempo vai passando, a gente vai passando mais coisas também, 
entendeu (...). Eu tinha vontade assim, quando o meu marido era vivo eu tinha vontade assim, de ter conforto, assim, não assim de gente rico, mas de pelo menos uma, um conforto, assim mais ou menos, é de ter uma casa, tivesse um móvel bão, então tudo isso (...), porque a gente assim, tudo isso eu pensava, assim, mas ele nunca pensou, nunca, nunca, então eu... Aquilo vinha me causando essas coisas, ficava preocupada com isso, dai ele faleceu, dai minha vida foi ficando mais dificil, dai eu fiquei doente, dai com 20 dias que ele foi sepultado, esse menino (filho), ele teve, fez, ele foi acidentado, foi acidentado, ai foi piorando, foi cada vez mais, dai eu fiquei doente, aí vem juntando isso tipo de coisa."

Silvia me disse que tinha duas casas, de uma outra casa ela recebia aluguel de cem reais para somar com a aposentadoria e a pensão, e que ficava muito longe, em um lugar muito ruim, mas que iria valorizar. A casa que morava era vista como boa, mostrando para mim sua feitura de tijolos, com área para ter suas plantas, justificando o porquê de morar ali:

"Porque aqui é por causa do recurso, por isso que a gente tem isso aqui, por causa disso, entendeu, tem o Hospital das Clínicas que é aqui pertinho, né, vou até de pé pra lá, tem farmácia aqui pertinho, tem supermercado por perto, na época que eu vinha prá cá com pedra na vesícula, e lá (na outra casa) não tinha condições, lá nem tinha luz elétrica... eu peguei o meu menino e vim pra cá, essa casa era um lixo... era triste, era terrivel, o chão era de chão (...), só que não é rebocada por dentro (paredes da casa), é uma casa bonitinha, tá murada, terreno é 5 de frente e 25 de cumprimento. A de lá eu nunca morei, agora tem luz, rede de esgoto, lá é um lugar longe, longe mesmo, se eu tiro um dia pra ir lá tem que ser um dia mesmo."

Quando perguntei para Silvia sobre o bairro ao lado com as casas luxuosas me disse que já quiseram fechar, murar o bairro e que algumas pessoas de lá são muito medrosas:

"Mas esses que tem a vida mais ou menos, esses que tem medo, tem um medo, nossa, eu tava fazendo caminhada e lá (...), ai ela (uma mulher) pegou a sacola e saiu depressa e saiu correndo, eu falei que não precisa correr de mim que eu não sou bicho, perguntei se ela tava achando que eu ia arrombar a sua casa, eu não vou invadir, que bobeira é essa. Ela disse que era pressa. Eles queriam murar o bairro luxuoso por causa da favela aqui, eles queriam murar (...), ai que ia chamar atenção mesmo (...), mas que bobeira. Eles queriam fazer um condomínio, mas não mexeram com isso não".

Entrevistei uma pessoa pertencente ao bairro das casas luxuosas que, apesar de dizer que poderia ser incluída sua entrevista na pesquisa, não quis assinar o termo 
de consentimento. Portanto, não utilizei esta entrevista, restringindo minha análise sobre esse bairro à observação participante. Nesse bairro as ruas eram mais largas, pouco movimentadas e as pessoas não ficavam sentadas na frente de suas casas como ocorreu em outros bairros. As casas, geralmente muradas com cercas elétricas, faziam parte de uma anatomia urbana significadora de medo e individualismo. Nesse bairro, o mundo era impessoal, ás vezes, acompanhado por um apito de um guarda privado em suas motos. Conversando com a senhora que entrevistei nesse bairro e explicando sobre a pesquisa que estava realizando, falei que em outras ocasiões até tiraria fotos, ocorreu-lhe um susto, dizendo-me que seria um absurdo se expor assim. Além disso, durante a entrevista ocorreram perguntas sobre o que eu iria colocar de sua fala na pesquisa. As casas pareciam ser completadas pelas tecnologias voltadas para a fiscalização e vigilância dos movimentos de pessoas suspeitas. Encontrei com um guarda e perguntei sobre o bairro, foi aí que me disse que nem sempre o que é protegido é honesto, que já uma casa tinha sido invadida pela polícia para "pegar bandidos". As fronteiras criadas entre este bairro e os outros não é somente uma demarcação do espaço físico, é também uma fronteira social, de habitus.

Antes de terminar a pesquisa de campo, estava fixada uma grande placa, dizendo sobre a urbanização da favela, nem sempre agradando a todos. A favela não só resiste à determinação de um tipo de espaço, resiste a um estilo de vida. Essa resistência é geradora de conflitos, conflitos que podem originar o consumo de medicamentos como os medicamentos psicoativos. Embaixo daquelas casas possui uma terra que conta história, revela um passado de lutas, tristezas e decepções, não é simplesmente o canavial de antes, é cortada pelos traços no chão de uma antiga estrada de ferro, que no passado serviu aos barões do café. Algumas casas apresentavam-se sobre esses trilhos, casas que são fixas, mas que possuem moradores que viajam ainda numa espécie de locomotiva do curso de vida, andando por vários lugares até chegarem ali, dando fim a uma longa caminhada, o cansaço provocado por este longo percurso simbólico e geográfico é somado pelas tristezas, pelo corpo que envelhece, pelas mortes, entre outros acontecimentos, servindo de reflexo para o consumo de medicamentos psicoativos. 
A pompa das casas luxuosas nem são tão notadas quanto o comportamento de seus moradores, a parte da favela geralmente nem comenta, a larga avenida que separa favela e bairro luxuoso distancia o olhar, fazendo com que um não enxergue o outro, mas o sinta, como percebi através do discurso de Silvia. Enquanto na favela a Universidade parece nem fazer parte do discurso de seus moradores, apresentando-se como se o campus da USP se restringisse aos serviços prestados pelo Hospital das Clínicas, pelo Centro de Saúde Escola (CSE) e pelos Núcleos de Saúde da Família (NSFs), a população pobre servindo como objeto de estudo, de espetáculo revelador de um sofrimento medicalizável, nos bairros das casas luxuosas e no bairro antigo podia-se notar a presença de alunos dos cursos fornecidos pela Universidade morando nesses bairros. O bairro luxuoso se transforma em reduto de um novo poder, silencioso, não participativo da vida dos moradores pobres financeiramente. Os moradores do bairro luxuoso se tornam ausentes, invisíveis, ninguém sabendo quem é quem e o que fazem, como se podiam localizar antes os coronéis, os grandes proprietários rurais, os doutores. No bairro luxuoso, as casas são reflexos de uma arquitetura que não lembra as casas dos antigos barões do café, como já mostrei a casa do Museu do Café localizada no campus da USP, mas faz lembrar as relações de poder, de dominado e dominante. A arquitetura desse bairro diz impessoalidade com seus muros altos e eletrificados, seus moradores, alguns possivelmente localizados em postos estratégicos na Universidade. Os antigos coronéis perdem espaço para uma impessoalidade que já não se localiza pelo patrimônio, pela localização de sua família na estrutura social, os nomes são impessoais, dando lugar às funções, muitas dessas representadas pela intelectualização do poder. O bairro luxuoso está longe da vida dos moradores da favela, das casas $\mathrm{COHAB}$, como também a participação da Universidade.

As relações de poder entre Silvia e seu filho são notadas pela imposição dos seus desejos, que vão desde o seu passado até o presente. São os conflitos relacionados com suas irmãs, pela disputa moral, de ser considerada a melhor filha, uma perfeição que se relaciona com os papéis determinados pela família, afirmando a existência de uma hierarquia de poder entre pais e filhos, devendo os filhos concorrer 
entre si para ascender à posição de filho predileto, e esta não sendo adquirida, tornase justificativa para um curso de vida considerado ruim:

"Outra coisa, quando eu era solteira, eu pensava assim, eu notei comigo que minha mãe gostava mais de uma irmã que de mim, entendeu, inclusive que quando eu casei eu notei que ela não fez muita conta não, então a gente vai guardando, a cabeça é um computador, né, não esquece. A gente vem notando, até depois de casada também, ai ela passava mais na casa das outras irmãs do que na minha, então vem... foi indo essas coisas, tudo isso vai juntando, dai quando a gente entra em depressão vem essas coisas também (...). Eu nunca falei nada, mas fica meio na cabeça da gente 'porque fulana é melhor do que eu, não tem nada melhor do que eu' (...). O meu pai era um jeito só, naquele tempo a gente tinha muito medo dos pais da gente, (...), a familia dele, avô dele que era do nordeste, a bisavô dele era índio."

Aparentemente preocupada com o filho, com os caminhos que o filho poderia trilhar, Silvia mostra-se exigente, dizendo que às vezes se sente só, que filho não faz companhia para os pais, reclamando das desordens ocorridas na atualidade relacionadas com as famílias quando comparadas com o passado, mostrando que os modelos educacionais aprendidos com os pais deveriam ser seguidos. O domínio sobre o filho é notado através da preocupação que teve com a sua ex-namorada: "eu senti ciúme da namorada dele, mas eu pensei que ele precisa, né, mas achei bom ter terminado". Além disso, o medo que o filho consuma bebida alcoólica e não trabalhe colabora para que o álcool seja visto como enfraquecendo o corpo e o vigor para o trabalho:

“O meu pai era bem escuro do cabelo liso (...). Naquele tempo não tinha lei igual agora (...), hoje um pai nem pode bater no filho, não pode, as coisas hoje em dia tá muito evoluída, muito adiantada, não tem respeito (...). Se tivesse conversando com um, não gostava de ficar perto, a minha mãe e meu pai, a mesma coisa. Agora hoje não, eles tratam a mãe como irmão. Tem mãe que sabe que os filhos tão fazendo coisa errada e apóia os filhos (...), depois gera desgosto pra família, o negócio, o importante é a igreja evangélica, ela ajuda, ajuda a acabar com o vício, vício de bebida, vício de droga, se os pais pega com deus, os filhos vai também. Tinha irmão, morreu de tanto beber, morreu novo. Pode notar que as pessoas que bebe é novo mas a aparência é de velho, é um bagaço, não aguenta trabalhar."

Fiz duas entrevistas com Silvia. A primeira entrevista foi interrompida por estar próximo do horário de ela ir à igreja evangélica, lugar que encontraria sua irmã 
e suas sobrinhas, mas ela solicitou que eu retornasse depois. Quando terminei a primeira entrevista o jantar já estava pronto, ela achou que a conversa tinha sido muito curta e me disse: "a gente tem que encontrar porque a gente não falou tudo, né, a vida da gente é curta mais é longa também, um pouquinho, porque de quando a gente nasceu e vem vivendo, né, ela é um pouquinho longa, né, vai contando tudo na vida da gente, é longa..." Silvia mostrou o quanto poucas horas, às vezes, minutos, em que se realiza uma entrevista são poucos para descobrir um pouco sobre o outro. Quando pedi para tirar fotos ela ficou muito preocupada com sua aparência. Algumas fotos que tirei foram entregues aos entrevistados, sendo guardadas como lembranças.

O envelhecimento de pessoas pertencentes aos grupos populares pode estar relacionado ao não encontro com as normas de modelos de vida que foram impostas no decorrer de suas vidas, gerando possivelmente sensações de fracasso, insuficiência frente às coerções sociais, podendo esta sensação ser aumentada com o aumento da idade ou o surgimento de doenças e mortes dos familiares. Desse modo, quando entrevistei Carmina (76 anos), moradora das casas $\mathrm{COHAB}$, fiquei sabendo que dois filhos seus haviam morrido de câncer. Na primeira visita ela não estava, viajava para outra cidade para encontrar sua outra filha. Carmina morava ali com uma neta e sua filha que também iria fazer a sua terceira cirurgia por ter também câncer. Os filhos haviam morrido devido a câncer no pulmão e na garganta. Foi depois da morte de um desses filhos, com o qual ela morava junto em outra cidade, que ela começou a utilizar os medicamentos psicoativos por ter ficado "muito abatida". A filha que morava junto com ela me disse que o médico referiu que estava muito avançada a doença de Carmina, num estágio muito profundo.

Os medicamentos psicoativos servem de parâmetro para dizer à filha que nada vai bem, fazenda da filha uma fiscalizadora, olhando se ela perde o sorriso, se Carmina reclama dos efeitos dos medicamentos, se os sofrimentos não são ocultados. Uma espécie de hierarquia da morte é questionada quando Carmina não aceita que os filhos morram primeiro do que ela, e mesmo que fiquem doentes, sendo cuidados por ela. A morte perde o significado de ausência e passa a exprimir presença de um 
sofrimento que não deveria ser de Carmina. É como se os filhos mortos pudessem estar roubando a memória que deveria ser de Carmina, que corre o risco de ser esquecida entre os familiares pela morte antecipada dos filhos, e a expressão de sofrimento de Carmina se impõe aos que ficam. A doença suplanta a morte, a velhice fixa-se como doença, vitimiza-se para impor desejos, olhares, regras, memórias. A morte pode ocorrer a qualquer momento, súbita, como ocorreu com a irmã de Ivanilda, mas estar doente, uma doença crônica é levar a morte viver, ficar presente na memória daquele que cuida, que acompanha o doente, acompanha a evolução da doença, como aconteceu com Talita. A doença faz lembrar perda a todo o momento, faz aquele que cuida sentir-se culpado por essa possível perda, a doença domina o outro que cuida, faz parte das relações de poder entre gerações, entre cuidador e cuidado, entre pais e filhos. Sofrer e vencer são espécie de armas para um discurso que quer convencer, ser aprovado, por isso o sofrimento quando está relacionado aos ganhos financeiros, aos cuidados com os filhos, entre outros, carece de ser ouvido por, às vezes, transformar-se em orgulho, vitória, o "sofri, mas consegui", “criei os filhos". Porém, quando a morte daqueles que deveriam escutar as dores que o seu percurso de vida teve chega antes de pronunciar estas falas, o sofrimento se cala, consome o "sofredor", passa a não ser justificável. O "juntar" em todo o "movimentar-se" que a vida proporciona, os acontecimentos que ocorrem no decorrer da vida passam por um silenciamento. A casa pode aqui representar toda uma vida de desgaste, de esforço que busca ir além dos limites suportáveis pelo corpo, comprar uma casa necessita não só de dinheiro, precisa de justificativas sociais, valorização daqueles que vão morar, reconhecimento do sofrimento daquele(a) que é considerado o seu comprador. A compra de uma casa significa também posicionar-se em uma hierarquia de poder interna. E depois da casa pronta, comprada, os gastos diários com sua manutenção e a subsistência de seus habitantes exigem muitas vezes liderança que é representada pelo(a) chefe de família. O trabalhar para sustentar a casa não se resume à liberdade fora do ambiente doméstico, é também dominar este, como se observou entre Antônia e Orlando (referidos adiante). 
Carmina foi relatando sua vida, trabalhadora rural que veio do Pernambuco com treze anos de idade, já era casada e partia para o Estado de São Paulo, deixando os parentes para trás. Com o primeiro marido, falecido, teve três filhos, tendo outro companheiro, mas que não achou que foi "um bom negócio", tendo mais dois filhos. Como Silvia, Carmina exige do marido uma postura que possibilite maior conforto:

"Tenho 3 irmãos no Pernambuco. De primeira eu tinha contato, agora não tenho.... Tinha um irmã que não ficava uma semana sem ligar pra mim, ela era muito apegada comigo... Quando fez um ano que minha mãe morreu o meu pai morreu... O meu pai morreu em minha mão, eu fiquei tudo com as crianças pequenas em casa. A minha irmã mais velha tinha ido pro baile, ai eu fiquei tudo com as crianças pequenas em casa. O meu irmão mais velho trabalhava, vinha no fim de semana. Deus ajudou que ele veio... Tudo morreu novo. O que eu já passei na minha vida, não era pra eu tá mais aqui (...). Eu trabalhava em casa de familia, lavava, passava (...). Tive que trabalhar, os meninos pequenos, eu trabalhava de bóia fria, qualquer coisa eu fazia (...). Eu fiquei, vim primeira pra..., tocando roça, o meu marido tocava roça (...). O primeiro (marido) morreu, agora esse que eu falei que mandei pra fora, só falei uma coisa e não voltou mais não, falei a porta é ali, some, dai não apareceu, se aparecesse, eu não abria a porta mais (...). Ele não me dava nada, cê acha que uma pessoa que fica..., a gente tem que ter uma pessoa pra ajudar (...), não bebia, só não me dava as coisas."

Carmina foi morar em Ribeirão Preto devido à morte de sua filha que morava em outra cidade do interior paulista, sendo que a filha com quem morava junto foi para Ribeirão Preto devido ao tratamento que fazia no Hospital das Clínicas. Carmina disse que os medicamentos psicoativos a ajudaram a andar melhor, ter mais ânimo. O tempo e o espaço fizeram Carmina se distanciar dos parentes, "faz tantos anos que vim que não sei de saudades", concentrando-se no trabalho: "o tanto que dava pra trabalhar eu trabalhei".

O bairro era visto como calmo, apesar de, segundo Carmina, ocorrerem alguns tiroteios, tráfico de drogas, principalmente aos finais de semana, relatando sobre as brigas que os traficantes tiveram com uma moradora que ficava a poucos metros de sua casa, e que observei logo em seguida e vi que seria uma das pessoas que iria entrevistar, porém se recusou a dar entrevista. Esta mulher foi relatada como fofoqueira, que ficava ligando para a polícia devido a ocorrer vendas de drogas nas proximidades de sua casa, e que por isso estava tendo "problemas". Os moradores 
das casas da COHAB relataram que o tráfico persistia, revelando uma maior divisão entre pessoas que vendem drogas e o restante da população, formando um processo de distinção, de conflito que colabora para o consumo de medicamentos psicoativos.

Carmina mostrou a imposição de um modelo ideal de família frente a diversidade de construções familiares existentes (FONSECA, 2005), cobrando-se por não corresponder ao modelo considerado ideal. Carmina vivia uma vida fora das normas, vivia conflitos, resistia, mas os anos podem somar, juntar, uma condição que a morte dos entes queridos pode sensibilizar, titubear a determinação, a rigidez muscular de um corpo trabalhador e as sensações de impotência frente à morte. A morte está aqui mais presente, é como Silvia disse sobre os seus três filhos que haviam morrido pouco tempo depois de terem nascido, são as mortes violentas na favela, as doenças oportunistas que ocupam um corpo cansado, deprimido pela condição excessiva de trabalho que utilizou o corpo em más condições de vida.

4.3.6 Aquisição da casa própria: $\mathrm{COHAB}$, a casa dos sonhos é igual a do vizinho

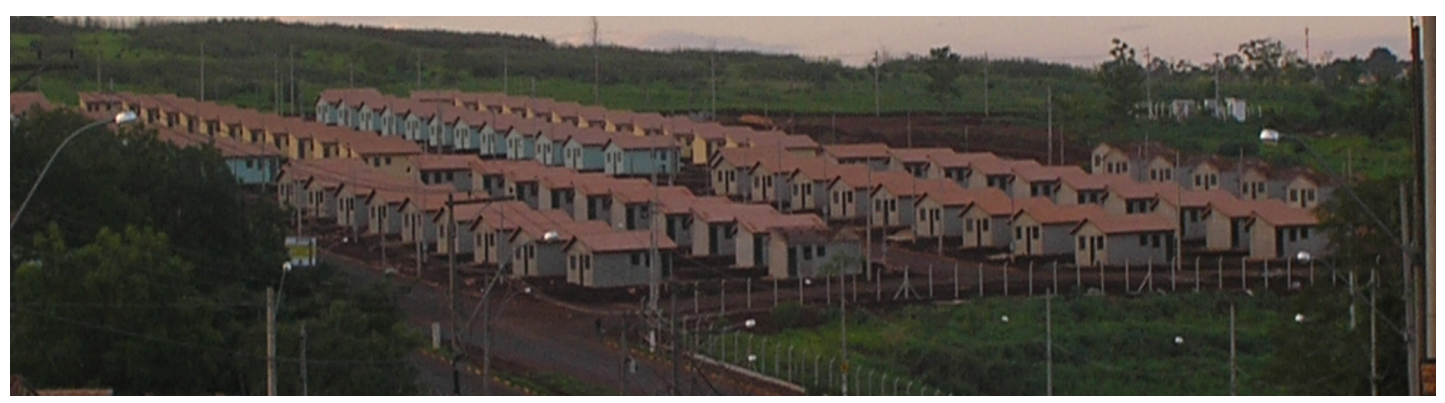

A parede de uma casa pode significar privacidade e valorização de espaços, desejos que não devem ser vistos, questionados. A casa na COHAB se transforma em um ambiente para os escolhidos entrarem, separando-se da rua por muros. Na favela 
algumas casas são separadas umas das outras por paredes construídas com materiais como pedaços de madeira, partes de geladeiras, papelão, havendo uma maior proximidade do espaço interno da casa com a rua. As casas do bairro COHAB são casas novas, muradas, construídas há pouco tempo, algumas inacabadas, sendo refeitas. As paredes representam barreiras não como um divisor de lados, não só como barreiras sociais, são barreiras individuais, o vizinho fica mais distante. $\mathrm{Na}$ favela as ruas quase se encontram, escutam o vizinho; no bairro antigo e na COHAB as paredes não fazem parte da rua. As imposições por segurança são notadas em todos os bairros, mas possuem conotações diferentes. Enquanto nas casas dos bairros antigos as garagens transformam-se em alpendres, muitos moradores sentados à porta nos finais de tarde, fazendo uma divisão de quem deve passar da porta da rua para a garagem e desta para a sala, da sala, adentrando as intimidades da casa; na favela a casa tem poucas divisões, entrar nesta casa pode significar invadir toda uma intimidade da casa, é ver ao mesmo tempo o lugar de dormir, do sexo, do tomar banho.

A favela esquenta, as casas com seus telhados baixos e inapropriados elevam a temperatura do ambiente da casa. Algumas mulheres que ficavam à porta de suas casas na favela me disseram que não ficavam em casa durante o dia porque lá era muito quente, por isso saíam e ficavam em lugares que tivessem sombra. Na favela a casa não aconchega, parece repelir os moradores, os eletrodomésticos e móveis parecem perder sua importância, as chuvas, a poeira e a insegurança podem a qualquer momento impedir seu funcionamento. No bairro luxuoso, com suas casas de paredes altas, com interfones, câmeras, guardas, cerca elétrica, e ruas quase sem transeuntes, a casa guarda segredos. No bairro COHAB as casas são muradas, assim como no bairro luxuoso e no bairro antigo, no entanto, geralmente apresentavam um buraco feito com cano no muro, para que a pessoa que coletava o medidor de eletricidade conseguisse olhar da calçada o relógio, não precisando entrar pelo portão. Esse buraco na parede também servia como uma espécie de interfone, algumas pessoas me atenderam por esse buraco, não pude ver seus rostos, somente uma boca que falou através de um cano que cortava a parede. Assim, tive uma 
mulher que me concedeu uma entrevista, e que foi realizada pelo cano, ela falou um pouco de sua vida pelo cano. Esses diferentes ambientes em que realizei as entrevistas me disseram bastante sobre minha posição de pesquisador e a do pesquisado, exigindo flexibilidade, posturas variáveis em decorrência dos diferentes encontros, revelando códigos, medos, diferenças e semelhanças sociais.

No bairro de casas COHAB, as pessoas, ao mesmo tempo em que ficavam na rua, alguns meninos jogando bola, de repente a rua parecia morrer, todo mundo parecia se esconder nas casas. A casa transforma-se em refúgio, todos ali de prontidão, fiscalizando os movimentos, os barulhos da rua. Quando entrei em uma casa pareceu-me que estava sendo vigiado, quando saí tinham várias pessoas ali perto, fora de suas casas, cochichando. A minha presença era notada e anotada, as paredes tinham não só bocas e ouvidos, tinham olhos. Fui a uma padaria, falei que estava fazendo uma pesquisa sobre o consumo de medicamentos ansiolíticos e antidepressivos e pude ouvir uma mulher me dizer que lá tinha muita gente com transtorno mental e enumerou algumas pessoas, e que ela mesma já tinha pedido para o médico prescrever os medicamentos para ela. Enquanto na favela a presença do Estado nem sempre era aceita, nas casas do bairro COHAB transparecia uma presença aceita, exigida, reafirmando um estado de higiene, de cuidado com o bairro. As ruas ali já estavam prontas, asfaltadas, enquanto a favela ainda esperava sua urbanização, construindo ruas que possibilitassem passar uma ambulância, como me disse uma moradora, simbolizando uma rua como espaço social medicalizado. No bairro não existia um Núcleo de Saúde da Família, tinha um posto de saúde construído, murado com arame farpado, mas que logo teria os agentes comunitários de saúde desejando adentrar aos lares de seus moradores (fotos seguintes). 

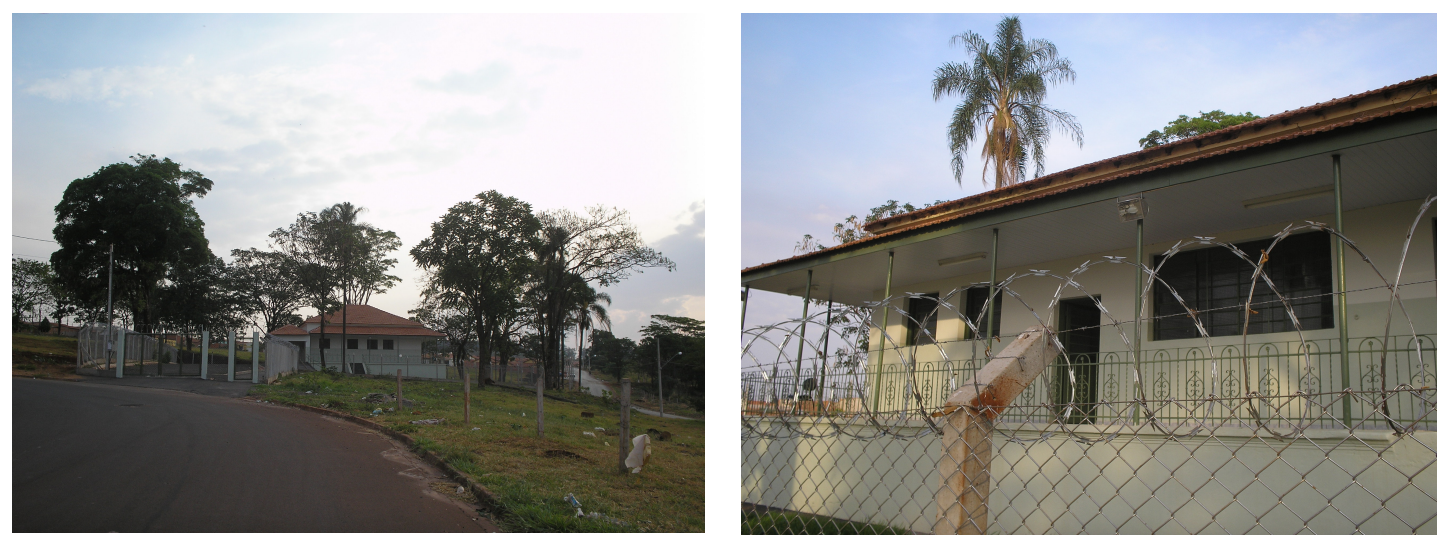

Desse modo, a medicalização através dos Núcleos de Saúde da Família acontecera por último no bairro da $\mathrm{COHAB}$ enquanto na favela as casas foram visitadas, fichadas para depois mencionar a urbanização. Os moradores da COHAB constroem um novo espaço que se afasta dos espaços liminares, entre bairro antigo e favela, e do interior destas áreas. São pessoas que se somam ali sem vínculo construído, e sim, a ser construído, essa condição gera tristeza, distanciamento da antiga casa, saudades, vontade de voltar. Uma senhora que havia entrevistado na favela me disse que não gostaria que sua filha, e esta concordando, fosse morar lá nas casas $\mathrm{COHAB}$, pois ficariam longe uma da outra, na favela uma morava em frente à outra. Os laços de amizade na favela são formados através de uma rede envolvendo familiares e amigos, as paredes quase não existindo como separação dessa rede, que amplia à medida que aumentam as dificuldades financeiras, o corpo adoece. Contudo, são redes silenciosas, difíceis de serem decifradas, achar um endereço precisa de uma iniciação no espaço da favela, precisa transmitir confiança, seriedade. Nas casas COHAB as pessoas parecem distantes umas das outras, mas dizendo o que uma é, o que faz e o que aconteceu em sua vida.

Quando digo liminar não me refiro exatamente a liminaridade, um rito de passagem como explica TURNER (1974), em que ocorre um estado de ausência, vazio, em que pessoas "saem" de suas posições na estrutura social e retornam para ocupar outros lugares na própria estrutura social ou das organizações sociais. A liminaridade formaria uma situação atípica em que pessoas se distanciam da estrutura 
social, criando um espaço de isolamento e passando por uma espécie de processo de reordenação de suas posições nessa estrutura. Nesse momento, ocorre o que TURNER (1974) chama de anti-estrutura, críticas à própria estrutura social vigente para sua remodelação. O que destaco não é uma passagem, uma transformação, e sim a construção histórico-social de um modelo e sua imposição aos grupos populares. Não diria aqui que ocorre um rito de passagem, mas a possibilidade de processo de aceitação social que se assemelha a condição narcísea deste modelo, o que implica relações de poder e resistência. A rua que divide a favela da parte antiga do bairro apresenta-se como espaço liminar, conflituoso na imposição deste modelo, pois implica não em um vazio que leva simplesmente a uma transição, um isolamento retornável, mas o confronto entre olhares diferentes a serem interpretados (GEERTZ, 1989). A rua não está na favela, ela é uma divisória com esta, estar nesta rua é aproximar-se da parte antiga, é ter suas casas com as costas para a favela, almejando estilos de vida alheios a esta, é ter a frente ou porta das casas orientadas para a parte antiga do bairro, com casas consideradas melhores. Nessa condição de busca para mover simbolicamente suas casas para o outro lado da rua é também um projeção sobre-humana, utilizando os limites do corpo e o apoio da religião. A religião e os medicamentos psicoativos são unidos para construir este processo de aceitação social.

Assim, os moradores, ao procurarem atravessar simbolicamente a rua, apenas a aquisição de dinheiro não é suficiente, deve-se mostrar moral, honra de acordo com os preceitos do outro lado da rua, levando a realização de provas, de comportamentos considerados aceitos pela outra parte. Nesse sentido, ocorrem conflitos, o morador da favela deve esquecer-se, anular-se, esvaziar-se com esquecimentos e preencher-se de um novo estilo de vida, possivelmente gerando angústias. São os sintomas desses conflitos que freqüentemente chegam aos serviços de saúde para serem tratados. Porém, o olhar médico não se aprofundará sobre a estrutura social como faz com as estruturas anatomopatógicas, os sintomas "sociais" serão confundidos com/reduzidos a sintomas de doenças. Contudo, o morador da favela não irá se transformar em um morador da parte antiga, suas casas não serão como as de lá, o que reafirma 
distinções e subalternidades, submissão através da urbanização da favela. Muitas vezes, uma casa não é conseguida através de um projeto que atravessa gerações. A aquisição de uma casa por grupos populares envolve também a configuração de seus moradores aos trabalhos a que se submetem para conseguirem a casa própria. Além disso, a mudança de local de morada envolve angústias de vida, os espaços também produzem uma relação sentimental, afetiva com os moradores, pois estes os constroem em conjunto com a sua vida, produzindo identificações (TAVARES e ALBERTINI, 2005).

$\mathrm{Na}$ favela, a aceitação não se restringe somente a uma pessoa, o pesquisador tem que circular por algumas casas. $\mathrm{O}$ diálogo tende a ser coletivo e os acontecimentos que devem ser silenciados não se restringem a quatro paredes a aqueles que deveriam saber. O diálogo é simbolicamente público e todos passam a saber o que não pode ser dito, como os acontecimentos relacionados ao que é considerado ilícito. O não dito, falado, é comunicado, é interpretado.

As fofocas depreciativas podem até se caracterizar como uma defesa, utilizando preconceitos formados pelas pessoas que não moram ali, são atos e posturas recriminadas por um grupo social sobre o outro, colaborando para a distinção, fazer saber quem é estabelecido e quem é outsider (ELIAS e SCOTSON, 2000). Aqui o morador da favela pode utilizar a fofoca também a seu favor, como resistência, dizendo não para a presença de leis, perpetuando posições vantajosas de alguns moradores sobre os demais, sendo favorecida pela condição de isolamento social.

Assim, a afirmação por alguns moradores de que a favela é violenta, que vende drogas, discriminando os outros moradores pode significar vantagens individuais. Desse modo, ouvi muitos acontecimentos que não eram verdades, como a de que "desovou esta noite o corpo de dois aqui", "aqui morre todo dia", "à noite aqui é terrivel'. A fofoca, ao contribuir para definir quem é quem não podia deixar de me incluir, a minha distância do Núcleo de Saúde da Família e a maior aproximação com os moradores da favela, levou uma moradora a me dizer que "oh, o pessoal do núcleo fica falando de você, falam que você vive ai nos botecos 
bebendo, que pesquisador é esse que fica nos bares" e que ela não deixaria ninguém deles entrar em sua casa, dizendo que são uns fofoqueiros, e que falam tudo que tem lá depois. Desse modo, as posturas relacionadas a uma ordem estabelecida, como correta, constitui-se através do discurso dos serviços de saúde, impondo este discurso para a população usuária do serviço. A necessidade de se distinguir dos considerados iguais por viverem numa condição socioeconômica semelhante e desfavorável quando comparados a outros grupos sociais pode contribuir para que os agentes comunitários de saúde percam sua referência social e passem a condenar atitudes e comportamentos de seu próprio grupo para se distinguirem dele, reafirmando preconceitos e o domínio de um grupo social sobre o outro. Os agentes comunitários com seus jalecos brancos de saúde, ao transitarem por estes dois espaços, dos serviços de saúde e da população usuária do serviço, passam a ser vistos como constantes vigilantes, disciplinadores através da fofoca, dos julgamentos, distanciando de uma relação dialógica entre serviços de saúde e população, apesar de vivendo em condições de afastamento social e econômico como os moradores da favela, mas provocando relações de domínio, de conflitos, fronteiras, como as que foram notadas na dispensação de medicamentos pela farmácia pública.

Nas casas da COHAB, a imposição de uma homogeneidade à estrutura das casas, não impede que os seus moradores possuam cursos de vida particularizados, sendo relatados por algumas horas algumas partes deste curso, desse movimentar-se e juntar. Essa parte em que entrevistei os consumidores de medicamentos psicoativos não fazia parte da área de abrangência do Núcleo de Saúde da Família, porém foi conveniente incluí-la por fazer fronteira com a favela e ser um novo tipo de estrutura de bairro, feitas por casas populares. A favela também passaria a ser transformada nesse modelo de bairro, visto que também passava por processo de urbanização através da COHAB.

Como já foi mostrada anteriormente, a compra de uma casa, o cuidado voltado para ela significa muito para os moradores de grupos populares, fixando-se e fundindo espaço e tempo, "criando raízes" no local. A mudança de um bairro para outro pode ser muito importante para uma família, podendo gerar vários conflitos 
tanto internamente no espaço da casa como fora. As relações estabelecidas anteriormente podem ser rompidas. O distanciamento de laços já fixados pode assim gerar desconforto e aflição, levando a destacar outros conflitos já antes negociados. Nesse contexto, fui fazer uma entrevista em uma casa que ficava próxima a favela, inicialmente a entrevista iria ser feita somente com um homem, Orlando (48 anos, nascido no interior mineiro), mas sua mulher, Antônia (56 anos, nascida em outra cidade do interior paulista), ao dizer que também tomava os medicamentos, eu a convidei a participar da entrevista. Esta entrevista ganhou uma particularidade inusitada, revelando como toda a pesquisa de campo na etnografia ao acompanhar os acontecimentos da vida diária dos moradores dos bairros convive com $\mathrm{o}$ imprevisível, o imediato e o acaso, possibilitando que o trabalho seja enriquecido e se aproxime da realidade dos moradores, levando a reflexão sobre as formalidades que o pesquisar exige. A entrevista revelou as existências faladas dos conflitos, Orlando e Antônia trocaram acusações, de repente, eu participava de um conflito envolvendo gênero, dificuldades econômicas, distinções entre grupos sociais vizinhos e consumo de medicamentos psicoativos. O homem disse que tomava os dois medicamentos, ansiolíticos e antidepressivos, enquanto a mulher dizia que praticamente só tomava o antidepressivo.

Inicialmente, apenas o homem estava falando, disse que moravam em outro bairro, em casa de aluguel e que estava muito satisfeito de estar morando ali, pois tinha adquirido aquela casa, dizendo que tomava os medicamentos para ficar mais calmo e dormir, pois tinha que acordar muito cedo para a realização de seu trabalho, que era muito difícil e que também tinha aquele estabelecimento de vender verduras e frutas. Este comércio era uma extensão da casa, sendo a cozinha o cômodo imediato, facilitando ver sua esposa nesta parte da casa, arrumando-a. Da cozinha era possível ver a rua, uma ligação, no entanto, interceptada pelo comércio.

A casa foi muito enfatizada pelo homem, falando dos quartos e do tamanho da garagem, apresentando com orgulho e dizendo que teve que trabalhar muito para comprá-la. Assim, os motivos de uso destes medicamentos se concentraram numa 
relação de trabalho para a aquisição de melhores condições de vida, que toda aquela vida de trabalho o fazia perder o controle, ficar nervoso, inclusive com a mulher.

A mulher, que não estava incluída na pesquisa, falou-me que também queria participar. Ela ficou aparentemente irritada com o marido, disse que ele dormia sempre à tarde, depois de chegar do trabalho, e ela tinha que cuidar do comércio e da casa e que tomava os medicamentos porque ele a maltratava, não a ajudava. Ele disse que não, que chegava muito cansado, pois só por isso ele tinha comprado a casa, e valia o sacrifício. Ele começou a discutir e me falou que se não tivesse feito o que fez, estaria do outro lado da rua (referindo-se à favela), sem destino, não tendo a casa para morar.

A mulher disse que não era sempre que tomava os medicamentos, intensificando-se nos dias em que o marido estava nervoso e também depois que ele comprou a casa e eles mudaram de bairro. A mulher disse que também trabalhava fora como passadeira e que não precisava do dinheiro dele para sobreviver. $O$ homem respondeu que era bom comprador e que a mulher não sabia comprar, e também por isso ele tinha a casa e o comércio. As relações entre domínio masculino e de uma classe social sobre a outra são destacadas no decorrer da entrevista.

Orlando e Antônia revelaram dois pólos: relativos ao gênero masculino e feminino e à condição socioeconômica. Referi a estes dois pólos como frutos das relações de poder. Sendo o trabalho do homem visto como de mais valor do que o realizado pela mulher e em casa, mesmo estando o estabelecimento comercial incluído nesta, foi utilizado para justificar seu comportamento impositor, chegando às vezes a ser agressivo, levando ao consumo dos medicamentos. A mulher, encontrando-se no lar, cuidava dos afazeres da casa e também atendia os clientes no comércio, dizendo que ficava muito nervosa pelo seu duplo trabalho na casa, não se referindo ao trabalho externo. Ele dizia procurar um futuro promissor e tranqüilo com a casa própria. O trabalho de Orlando fora do espaço doméstico era tido como mais importante do que o trabalho de sua mulher como passadeira, assim como todos os afazeres domésticos, aqui acrescido de um comércio de verduras e frutas anexado a casa. 
Os medicamentos ansiolíticos e antidepressivos contribuíram para definir espaços de poder do homem e da mulher, estando inseridos na polarização homem administrador e comerciante versus mulher ajudante e dona-de-casa. O comércio, quando realizado no ambiente doméstico, é colocado pela mulher como pertencente ao homem. Este, defendendo-se, pelo fato do comércio ficar no ambiente doméstico, o coloca como obrigação da mulher, mas sob o seu domínio administrativo.

Os conflitos entre funções e espaços de poder estariam contribuindo para o consumo dos medicamentos. Os ganhos financeiros foram vistos como externos à casa e do homem, servindo para justificar seu comportamento de domínio sobre o ambiente doméstico. A mulher corresponde com um trabalho doméstico disciplinado, mesmo quando acopla outros trabalhos. Nesse sentido, pode-se também verificar que o trabalho doméstico, mesmo quando remunerado, não é valorizado e se relaciona ao silenciamento imposto à mulher (PERROT, 2007).

$\mathrm{O}$ conceito de gênero não se restringe às aparências biológicas, faz parte do universo relacional, espaço de comunicação e compreensão de conflitos (BOURDIEU, 1999; BUTLER, 2003). Os conflitos entre Orlando e Antônia revelam as dificuldades de fixar lugares de poder considerados de um e de outro, assim como as condenações sobre o distanciamento das normas impostas como modelo, como as traições ao ter relações com outras mulheres, sendo de acordo com Orlando favorecidas pela relação de domínio masculino e condições financeiras. Desse modo, os desvios dessa polarização se tornam susceptíveis ao uso de medicamentos, manipulando comportamentos, desfazendo resistências (FOUCAULT, 1988) e procurando naturalizar relações de dominação de uma classe sobre outra e de um sexo sobre o outro (BOURDIEU, 1999), definindo espaços e comportamentos. Nesse sentido, pode-se dizer que o significado dado a esta polarização é coletivamente aceito, fazendo parte de um sistema de relações de poder, definindo papéis e sua normalização/normatização. Nessa perspectiva, LOURO (2004) diz:

"Para garantir a coerência e a permanência da norma, são realizados investimentos - continuados, reiterativos, repetitivos. Investimentos produzidos a partir de múltiplas instâncias sociais e culturais: postos em ação pelas famílias, pelas escolas, pelas igrejas, pelas leis, pela mídia ou pelos 
médicos, com o propósito de afirmar e reafirmar as normas que regulam os gêneros e as sexualidades" (LOURO, 2004, p. 82).

A polarização pobre/rico ocasionada pela condição de classe social produz um modelo idealizado de comportamento de homem administrador dos negócios e que "sustenta" a casa, que freqüentemente entra em confronto com a outra polarização homem/mulher. Assim, o trabalho faz intensificar esta polarização, aumentando sua imposição no ambiente doméstico, reafirmando o pólo homem/mulher. A mulher, para suportar esta imposição, faz uso dos medicamentos como um colaborador. Nesse sentido, a mulher chega a requerer sua vida passada, em que se considerava mais pobre, antes do marido dizer ter comprado a casa.

As nuances dessas polarizações, ao serem medicalizadas, transformam-se em sintomas, reafirmando conotação de desvio e de patologização. $\mathrm{O}$ trabalho exige dedicações para um produzir intensificado, para que o homem não perca prestígio social e seja contestado. Desse modo, para o homem, pobreza perde sua referência como problema social e se fixa individualmente, possuindo sentido de incapacidade, incompetência, falta de masculinidade. O pavor de ficar em condição considerada de pobreza justificaria o consumo dos medicamentos psicoativos. O trabalho de donade-casa foi defendido como domínio e orgulho da mulher (SARTI, 2003), mas é o homem que é mostrado como o dono (proprietário) da casa e, quando solicitada sua colaboração nos afazeres envolvendo a casa, sua resposta negativa é justificada pela posição de administrador da casa e dos negócios e pela valorização de seu trabalhado como cansativo.

Antônia não questionou todos os afazeres da casa, ela questionou um serviço não previsto, aquele que envolve a venda de verduras e frutas, é este trabalho que se confunde com a casa, sendo para Orlando também parte do trabalho de Antônia ao fazer parte da casa, porém a parte que envolvia negociações como a compra de mercadorias foi dita de sua exclusividade. O comércio que deveria ser função masculina, ao se fundir com a casa, entrou em conflito entre os espaços masculinos e femininos. O trabalho do comércio se confrontou com o cansaço de Orlando e Antônia com seus outros trabalhos fora do espaço doméstico, Orlando considerando 
o seu trabalho como cansativo e mais significativo do que o de Antônia, reafirmando a desvalorização do trabalho doméstico interno a sua própria casa. Antônia exigia de Orlando auxílio no trabalho da venda de verduras e frutas, e não nos outros afazeres domésticos, o comércio ao tirar de Antônia a dedicação exclusiva à casa e aos afazeres domésticos passa a ser questionado.

$\mathrm{O}$ conflito tenta responder uma pergunta que está relacionada à busca de melhores condições de vida: se o mundo dos negócios faz parte das atividades masculinas e do ambiente externo a casa, como definir os negócios quando estão anexados a casa, o que fazer quando rua e casa se confundem? É o conflito gerado por essa pergunta que é medicado. A mulher reclamou que queria somente uma casa e não uma casa-negócio e o homem dizia que tudo que tinha dentro da casa como afazeres era pertencente à mulher, com exceção daquilo que podia ser separado da casa por alguns momentos, a compra de mercadorias, que definia o homem como dono, colocando a mulher como auxiliar. A compra de mercadorias foi vista por Orlando como complexa, precisando de um saber, de traquejo, um saber-poder, precisando de masculinidade, a mulher é posta como inferior por ser colocada como ineficiente para comprar. Orlando se dizia fazer contas de cabeça, ter destreza para o negócio e por isso se dizia mais hábil para fazer as compras para o sacolão. Aqui, o negócio, o comércio, as negociações foram vistas como de Orlando, fazendo dele o dono, levando a venda carregar o seu nome pela população, é o "sacolão do seu Orlando". Porém, devido ao comércio ser anexado a casa, Orlando se impunha e dizia que era ela quem deveria cuidar da venda, da limpeza, deveria cuidar do "sacolão do Orlando", a casa como local de morada se confundia com o comércio. Antônio tentava se proteger do excesso de trabalho da casa, agora uma casa-sacolão do Orlando, dizendo que as atividades envolvendo o sacolão deviam ser de Orlando, mas ela não queria muito, ela queria mais ajuda, pedindo tempo para que os outros afazeres domésticos fossem executados com perfeição, valorizasse sua moral como mulher limpa e asseada. Os desdobramentos do corpo foram acumulados no ambiente doméstico, antes Antônia tendo o seu trabalho fora da casa como doméstica e os afazeres de sua própria casa somaram-se ao do sacolão, a casa ao virar casa- 
negócio faz Orlando ter um grau de dono ainda mais intenso do que quando era somente uma casa, uma morada.

A casa se apresenta como uma unidade administrativa de Orlando, incluindo os afazeres considerados exclusivos de Antônia. Os acontecimentos que levaram a acrescentar outro trabalho são agregados às tarefas de Antônia, passando estas por avaliação por parte de Orlando. Contribuindo para a desvalorização desses trabalhos, eles são vistos como trabalho de ajudante, Antônia diz que ajuda Orlando, mas que tudo ali é dele, confundindo relações sentimentais com força de trabalho não remunerada. Assim, o trabalho que o sacolão exige não foi visto como trabalho.

Sendo possivelmente retirada de um espaço em que tinha amizade com outras mulheres, estando isolada por ser uma moradora nova, sem ter ainda novas amizades para expor seu sofrimento, Antônia não pode se revelar "valente", como descrito por FONSECA (2000), fazendo uso da palavra, das condenações do comportamento do marido através de vizinhos e amigas. Além disso, a mudança de vizinhos nos deslocamentos de um bairro para o outro fez aflorarem diferenças, desigualdades e medos, buscando nos medicamentos alívio e conforto em um sentido individualista, funcionando como silenciadores de conflitos. Orlando coloca-se na condição de dominador masculino, sofrendo as conseqüências desse dominar, as exigências de dar conta dos "negócios", de ganhar dinheiro suficiente para manter seu modo de vida, relatando os desgastes que esta posição proporciona e me mostrando que, para defender esta condição como sua, contribui para que Antônia e as atividades desenvolvidas por ela sejam silenciadas. Orlando, apresentando receio de ser considerado desapercebido impõe que o trabalho exercido por Antônia seja despercebido, destacando uma realidade social quando as diferenças entre homens e mulheres mostrada pelos salários inferiores das mulheres quando comparado aos dos homens, a desvalorização do trabalho doméstico e os outros trabalhos que venham a se confundir com este.

Orlando fiscaliza os ganhos do sacolão, controla o dinheiro, este não representa somente a manutenção de um estilo de vida, significa também defender um lugar social, que vai desde a possibilidade de ter outras mulheres além de 
Antônia. Orlando sofre não apenas por dinheiro, trabalha continuamente para defender esse lugar, não ser questionado como fraco, sua honra está em jogo, quando o seu corpo já não suporta o excesso de trabalho, impõe a Antônia um trabalho que era definido como seu, mas aplicando um processo de invisibilidade ao trabalho de Antônia ao ser ele o negociante, preservando sua honra e masculinidade, não deixando possibilidade de domínio para Antônia. Antônia revida, questiona, o conflito aflora do encontro entre rua (representando negócios) e casa (mundo privado da mulher) (DAMATTA, 1997), revelando que este encontro não é tão harmônico o quanto já aparentou ser. As dificuldades econômicas e a insuficiência do salário de Orlando e o cansaço do corpo, não suportando outros trabalhos, faz com que Orlando garanta sua honra masculina ao impossibilitar que o trabalho de Antônia não seja visto como dela, confundido moradia com trabalho, por isso não a deixa comprar as mercadorias, a casa-negócio não pode se transformar na casa e no sacolão da dona Antônia.

A casa faz com que ocorra uma distinção com os moradores da favela, cada nova reforma revela diferenças, não é somente uma casa, é uma linha que demarca o vizinho morador da favela. Orlando se garante como bom, inteligente, "com a cabeça no lugar", é disciplinado por possuir uma casa. Antônia não quer essa casa, quer uma casa sua, quer suas amizades do outro bairro, ali está vulnerável a uma coerção social masculina. Mas Antônia luta, resiste, no poder há resistência. Encontrei Orlando quando fui entregar uma foto de uma igreja que ficava ali perto para uma senhora que havia me pedido, quando me viu tirando as fotos e fui ao sacolão comprar umas verduras, Orlando me disse que iria vender a casa e mudar. Antônia exigia que sua intimidade fosse preservada, pois dizia que ao entrar no sacolão outras pessoas poderiam ver partes internas da casa, assim, a casa fica pública, a casa vai para a rua e Antônia se vê exposta. O banheiro e o quarto mostram sua maior intimidade e por isso outras pessoas não podem circular por esses espaços da casa, lugares em que expõe o corpo, a sexualidade. Caso venha a ter uma empregada doméstica uma hierarquia é estabelecida, não usar o banheiro. As exigências que Silvia tinha de seu marido para lhe dar uma vida com maior conforto, com uma casa 
confortável, são aqui com a casa já adquirida e as conseqüências que a compra da casa gerou. Alguns desses conflitos que aqui relatei são mostrados em parte da entrevista abaixo:

"Antônia: ah, foi depois que nós mudamos pra cá que eu comecei, antes eu nunca tinha tomado isto não, viu, passo muito nervoso, nervoso demais, demais, demais. (...). É muito bom lá, adoro lá (o outro bairro).

Orlando: é bom assim, porque, quem gosta, quem tem propriedade própria, é bão né, mas isso aqui, depois que eu peguei aqui, então é...

Antônia: isso aqui que me faz passar muito nervoso, ele me deixa muito nervosa, é por causa disso aqui que eu passo muito nervoso. Acho que minha vida vale mais do que isso aqui. Eu acho.

Orlando: Não num vamos falar?

Antônia: mas ele quer saber, mas o que levou isso foi o estado emocional da gente,

Orlando: num fala pra ele esse negócio...

Antônia: Nossa! Pelo amor de Deus!

Orlando: vem com oito anos que eu peguei isso aqui, venho oito anos, então vem mutirão, pagava aluguel. Eu doido pagando aluguel...(...) O que eu fazia lá era pra pagar aluguel. Se eu não tivesse construído, hoje eu não tinha jeito, mas de pagar, eu mesmo ficando doente dos nervos, os meus nervos foram acabando, foi. Eu consegui uma coisa pra ficar melhor, melhorzinho, melhorar um pouco de situação. Então eu fui deixando tudo aqui. E tinha que ir pro meu serviço. E ela 'porque se vai cedo, cê tem outra lá'. Eu arrumei dinheiro no banco, prestação pra pagar, preocupado em pagar as dívidas, e ela ah porque ocê vai cedo. Ia Tudo isso aí. Então onde eu senti...

Antônia: mas ele, uma coisinha deste tamanho (mostra o dedo polegar com o indicador), ele faz uma deste tamanho (mostra os braços abertos). Sabe, num precisa disso.

Orlando: é só uma entrevista, num precisa...

Antônia: mas é isso que ele quer saber, da vida, do cotidiano. $O$ porquê que levou a gente tomar esses remédios. É tudo isso que levou a gente tomar esses remédios, é estado emocional, tudo.

Orlando: esses nervos aqui tá tudo dolorido (mostra os braços). Eu num consigo dormir sossegado. Esses nervos do pescoço, das costas. Eu que fico três quatro meses sem tomar uma cerveja e dai eu bebo e aí dói tudo, os nervos, os ossos, os dedos. Eu num consigo. Eu onde eu trabalho, faz 28 anos, trabalho lá dentro. (...). Eu piso lá dentro, pra mim é como solta uma bomba, eu já fico... eu num posso olhar ninguém, nem o meu patrão. De primeira, agora não, depois que eu comecei a tratar, a tomar esses remédios aí, que eu melhorei um pouquinho. Eu oiava assim, eu oiava o meu patrão assim e dava de vontade de chegar e rumar, de rumar... de rumar a cabeça dele no caminhão até explodir tudo. Eu chegava em casa, eu oiava ela assim 
e dava vontade, eu oiava ela assim e olhava a faca e dava tanta vontade de dá tanta facada e ai eu falava ocê some de perto de mim. Aí foi.(...).

Antônia: isso não é normal. Eu acho que não é normal. Eu posso falar que tô nervosa do jeito que for, mas falar em pegar uma faca, jamais. (...). Não é normal. Sabe, dessa vida a gente não leva nada, você só se prejudica. Quê que ocê leva dessa vida? Depois você morre. Amanhã depois ocê morre e dai fica aí. Faz uma tempestade toda, sabe.

Orlando: eu deveria ter... assim, que eu tava com uns 50 e 60 anos, chega aos 60 eu tá mais tranqüilo um pouquinho. Sair do serviço pesado, deixar de carregar os carrinhos pesados. Eu chego lá às três da manhã, saio as oito arrastando aqueles carrinhos pesados. Eu chego aqui ela fala 'o que cê tava fazendo, o que cê vai fazer'.

Antônia: Ele não admite que eu pergunto, eu sou mulher dele e eu que tenho que perguntar, cê chegou agora, por que, o que aconteceu, é isso, ele não admite, num é normal a mulher perguntar pro marido? Assim, às vezes eu chego e ele pergunta, eu trabalho na parte da manha, é a mesma coisa, igual ele pergunta, 'nossa, até agora'. Eu trabalho, é a mesma coisa. É normal perguntar (fala com indignação), quem tem que saber da minha vida e da vida dele sou eu, não é ? Eu, que não tem nada demais eu perguntar. Oh, por que ocê chegou agora, o que aconteceu, ele não admite, não admite que pergunta.

Orlando: eu falo pra não sai daqui da frente (fala da sacolão), que já roubaram. Ela fala que tá aqui no tanque, ela larga isso aqui a mesma coisa que tá largando uma...

Antônia: não é nada, eu num largo, eu preocupo com isso, porque eu preciso... ele acha que eu num ligo, sabe. Se chegar um cliente eu venho atender, nossa, eu passo muito nervoso, eu acho que não vale a pena. Nossa! Eu acho que não vale a pena, eu acho que minha vida vale mais do que isso aqui, do que qualquer coisa.(...).

Orlando: o que eu ganho não dá (...).

Antônia: ele não tem paciência, ele não tem um pingo de paciência. A minha discussão é por causa disso, ichi, qualquer coisinha, ichi, nossa, ele fala, nossa, eu não admito isso.

Orlando: o que eu ganho é pra pagar aluguel, é prestação, (...) é prestação, água, luz e desdobra. O governo não ajuda, isso aqui é casa do povo... vem muito coisa, é cetesp 280 reais, só água vai 300 reais, com mais... vai mais de quatrocentos reais. E eu fico preocupado, não pode atrasar, atrasou... Eu tenho que pagar o banco, eu tenho que correr e ir lá pagar, então o que eu ganho, se eu fosse pagar só com isso aqui (venda de verduras e frutas) num dava.

Antônia: cê paga pouquinho. (...). Eu acho que o dinheiro que ele ganha não precisava disso aqui.

Antônia: então eu não tenho tempo de fazer o meu serviço, eu fico aqui, ele chega e deita, o meu serviço vai ficando, eu tenho que lavar roupa, passar, é faxina, vai ficando muita coisa sem fazer, e eu não suporto ver 
coisa suja. (...). Cedo eu levanto pra arrumar o café pra ele, dai depois coloco o relógio despertar, eu nem cai no sono de novo eu vou ter que levantar, eu levando cinco e meia todo o dia, então, eu queria deitar também (...). Eu fico de noite cochilando (...). Eu também queria uma cama pra descansar. Ele deita e dorme.

Orlando: eu deito pra descansar o corpo. Mas na cama a minha cabeça tá assim, tá ...

Antônia: mas você deita... Eu também levanto cedo, e olha que mulher não para, eu lavo eu passo, dona de casa é muita coisa...

Orlando: eu falo eu vou embora amanhã, porque tudo ela me acoa de tal maneira que não tem jeito nem de viver mais nessa situação, mas a gente não tem criança pequena, graças a Deus... (ela tem de outro relacionamento uma filha que vai fazer 20 anos). Ela me acoa de tal maneira eu que não tem, acabou, esse negócio de sexo, e ela acha que estou saindo pra rua.

Antônia: você não sabe como é... o jeito dele, as atitudes dele, com ele não tem diálogo, nós vamos conversar daí a pouco não tem como, como eu falo, cê tem que ter diálogo, não tem, então eu vou conversar com ele não tem jeito, não tem como,...

Orlando: às vezes eu abro uma hora mais cedo (o sacolão)...ela não entende.

Antônia: pra ele é o dinheiro, o dinheiro é em primeiro lugar pra ele, é o dinheiro, pra ele é o dinheiro, já falei pra ele.

Orlando: não é em primeiro lugar, é pra manter o meu nome limpo.

Antônia: é todo mundo, eu também, tenho as minha contas pra pagar. E não é por isso que eu vou deixar de fazer certas coisas...

Orlando: se eu não importasse, poderia ter o meu nome sujo, podia mexer com qualquer coisa...

Antônia: ele não sai pra nada, ninguém da família dele vem pra ficar o final de semana, pra nada, pra nada, a vida não vira em torno de trabalhar, trabalhar, a gente tem que dar uma arejada.

Orlando: ela acha que eu vou vender isso aqui e vou ficar pra mim.

Antônia: olha, ele tá falando uma coisa que eu não penso. Não. (...). Eu vou morrer por causa disso aqui? Eu não preciso... Sabe a gente podia viver numa boa, olha, mas ele é cabeça dura, com ele não tem diálogo. Não tem diálogo, a gente vai conversar e ele vem com outras coisas, não dá mais... Sabe, dificil.

Orlando: olha, se eu fosse cabeça mole, igual muita gente por aí, essa casa não tinha muro, não tinha aumentado isso aqui, não tinha aumentado no fundo, não tinha cercado no fundo, não tinha nada, do mesmo jeito que o povo da favela morava, eu também tava, eu também tava, eu não mexo com droga, não mexo com isso, trabalho honesto com meu serviço, com minhas coisas, faço minhas coisas, então se eu fosse viver assim, amanhã ou depois se vai pra onde, então podia... Amanhã ou depois vão perguntar 'se vai pra onde'... Eu preocupo... Ter um lugar, porque amanhã ou depois eu tenho que ter um lugar pra ficar. Se eu vender isso aí, se Deus me livre guarde, eu der 
um derrame, o qualquer coisa, se for pra mim der um derrame ou alguma coisa, eu prefiro morrer, eu pedir perdão pra Deus aí dá um jeito na vida. (...). Eu morava em outro bairro, lá vivia de aluguel, ela tinha a familia dela pra conversar, não tinha construção para fazer (fala de sua casa atual que não está totalmente terminada), se um pedreiro deixa cair tinta ela fala, se cair um barro ela fala, deixa eu falar... Ela quer pintar, deixar tudo limpinho, deixar pra família dela... Ela quer varrer, limpar deixar pra família dela....

Antônia: a minha família me conhece, sabe que eu sou uma mulher limpa, eu não gosto de bagunça. Sabe, chegava aqui atrás era aquela bagunça. Sabe que nem cachorra. Isso eu não suporto.

Orlando: ela começa a falar, ela sai fora do ar. Ela não deixa... se a gente vai sair, ela não fica aqui, se eu saio ela puxa a porta e fecha a porta.

Antônia: eu fico aqui, lavando, às vezes tá vazio, eu fico lá dentro, igual entrou um cara aqui, eu tava passando pano, outra hora eu tava lá no tanque, como é que eu vou limpar. Não tem como, eu fico ... Como é que eu faço, as pessoas chamam, eu venho atender, sabe... Deus que me perdoei é um verdadeiro inferno.

Orlando: eu morava numa casa boa, sabe, a menina dela tinha as coleguinhas, ficavam lá (...). Tem dia que a filha dela fica a noite inteirinha.... (Antônia) não deixa eu dormir... Ela (filha) não chega e ela (Antônia) sai e fica aqui fora, entra no quarto. Ela não deixa eu dormir.

Antônia: cê fala muito, Deus me livre (...). Aqui, nada é meu, é tudo dele, não tem nada meu...o dinheiro é dele, não é meu, é dele, eu não pego um centavo, eu tenho o meu dinheiro porque eu trabalho, então eu tenho que chamar ele. Então se o dinheiro estivesse na minha mão não precisava dele, eu comprava e vendia, agora é ele, não tem como eu fazer, tenho que chamar ele.... Eu apenas te ajudo aqui, quem compra é ele. Tenho que chamar ele, não tenho?

Orlando: ela não sabe comprar...

Antônia: eu só te ajudo aqui, quem compra é você.

Orlando: eu tô ampliando a casa, arrumando, estou fazendo um monte de coisa, o dinheiro não é meu, é nosso, eu vou fazer um monte de coisa. Se fosse meu, o dinheiro, eu tinha outra mulher outra casa lá, eu ficava aqui e descansava na outra, coisa que eu não faço, ganhava e gastava lá fora. (...).

Antônia: olha, o dinheiro, ora eu penso, não vale a pena, a minha vida vale mais do que qualquer coisa.... é porque com você não tem diálogo, foi o que eu acabei de falar agora. É complicado quando não tem diálogo.... É ignorância, pra falar o português claro.

Orlando: tudo que você vai fazer, faz coisa errada... tudo.

Antônia: você é certinho, só eu (...). Ah, esqueci, isso é normal esquecer alguma coisa, isso é normal.

Orlando: você vai anotar alguma coisa, fala que eu não falei. Agora pra frente é assim (...), é uma doença que tá havendo entre a gente, é nervo... 
Antônia: doença que não vale à pena, eu que não vou... A gente vai conversar, ele vem com seis pedradas. Eu vejo minhas irmãs, elas têm diálogos, aqui não.

Orlando: com ela não tem jeito, ela tem razão... a razão é dela, a gente não tem razão.

Antônia: imagina, eu reconheço quando eu estou errada.

Orlando: e ela trabaia com essas mué, que é mué de advogado, tudo largada, ela enche a cabeça lá e vem...só besteira...

Antônia: tá vendo, elas tudo trabalham...

Orlando: trabalha, mas depois do trabalho delas...

Antônia: olha, eu tenho a cabeça feita, tenho personalidade, ninguém faz a minha cabeça...

Orlando: olha eu fiz tudo isso aqui, não vou jogar fora assim de mão beijada.... não vou mesmo.(...). É uma vida sem sono, não pode dormir... a vida pesada...ela fica resmungando...

Antônia: eu não fico resmungando não, olha, quando ele chega ele tem que ficar aqui, ele vai deitar, ficar aqui pra mim fazer alguma coisa, eu trabalho fora, eu lavo, cozinho, arrumo, ele vai deitar. Ele tem que ficar aqui pra mim poder cuidar das coisas aqui dentro. É isso que ele não entende. Olha, ele levantou agora que você chegou, ele fica a tarde inteira, ele tem que ficar aqui para eu lavar roupa. A hora que quer a roupa, quer limpa e passada. A hora que sai ele chama a atenção, fala 'ora, se já tá aí no tanque', sabe, é dificil. A hora que eu vou, é a roupa dele que eu lavo primeiro. Ele fala 'me dá a minha roupa aí', não quer saber. Eu tenho que... A hora que chega alguém, eu venho atendo e volto... Se ele fica aqui, me ajuda, eu vou cuidar das coisas... (...).

Orlando: empregada eu não posso por, tudo ela fala que não presta.

Antônia: olha, roupa suja a gente lava em casa, eu já vou te falando, eu tive uma menina aqui que a gente pôs pra trabalhar, eu cheguei, ela tava dentro do meu quarto, pegando moeda, eu pensei 'tá certo isso?' Entrar dentro do meu quarto, uma menina pra serviço. Nossa, eu fiquei possessa, aquele dia eu tinha que botar ela pra rua, eu não admito. Quando ele pôr alguém, eu já falei, isso aqui vai ser lacrado, ele vai ter que colocar um banheiro, porque usar o meu banheiro eu não admito, pode falar o que for de mim, eu não admito. É mentira que eu cheguei e a menina tava dentro do quarto? Ele deitado na cama e ela pegando moeda... Ele deitado na cama e ela... Eu falei 'não presta', nem você (Orlando) e nem ela porque se ela fosse uma menina direita jamais ela... Ela tinha só chegado na porta e perguntado 'ocê tem umas moedas ai pra mim'... Não entrava, eu penso assim... A minha mãe era uma mulher muito direita e eu também... muito certa, ichi, então não vem (...). Não presta, como é que eu vou confiar numa menina que eu encontro o meu marido deitado na cama e ela pegando moeda no quarto, não presta, ela lá, oh olha qual é que é, não, ichi comigo não... Então você ... Eu não admito pouca vergonha, não admito mesmo, qual que é, menina que não presta, ela provou que não prestava, aquela vagabunda... é vagabunda 
só, vai... Põe um trem que presta aqui... Eu não admito, não admito mesmo, vai ter que fazer banheiro, mas pra fora...Vagabunda, não presta mesmo... eu tô falando o que eu não podia falar, moço? (...).

Orlando: eu pra mim.... Eu de uns tempos pra cá o que ela tá falando eu deixei pra lá. Meu patrão, o meu serviço o motorista é falando mete o pau, é, mete o pau, descarrega logo, quero ir embora cedo, eu tô deixando tudo pra lá, tô ficando, a cabeça, mais normal e tô tomando os remédios (...). Assim, uma semana eu tomo um, uma semana eu tomo outro, vai assim. (...).

Antônia: a amitriptilina é melhor ainda pra cabeça, ah. Eu comecei a tomar e melhorei, sabe...

Orlando: eu pensei, eu vou muito na igreja, eu até pensei um dia em sumir, pensei em enviar de baixo de uma carreta e acabar com tudo de uma vez.

Antônia: eu não penso jamais isso, jamais, pode ser o que for, tudo a gente tem que resolver numa boa, jamais vou tirar a minha vida, jamais, posso passar o que for, sabe.

Orlando: quando chego em casa parece que explode dentro da cabeça da gente, começa a falar... (Orlando também tem uma filha).

Antônia: sabe por que ela veio atrás dele pra registrar, porque agora ele tem uma casa, porque até quando a gente morava de aluguel ela não preocupava em ter o nome dele...

Antônio: é lei.

Antônia: será porque só agora ela veio? (...).

Orlando: não via a hora de pegar isso aqui, e doze anos que eu venho lutando pra pegar isso aqui, isso aqui nós pegô há nove anos atrás, vai fazer 4 que a gente tá aqui, aí veio mutirão... Daí eu vinha do serviço pra ficar aqui, trabalhando carregando cimento na cabeça, nas costas.

Antônia: sabe, de onde eu vou eu gosto. Eu sou daquelas pessoas que de onde eu vou eu gosto, sabe eu sou daquelas pessoas. Cê acha que eu não gosto daqui porque eu não ... Todo lugar eu me dou bem, sabe...

Orlando: de um ano pra cá começou essas drogaiada aqui, mas a polícia acabou com tudo... Agora tá assim (...). Aqui roubaram três vezes, uma eu tava pondo a laje, a outra ela tava ali dentro....

Antônia: eu falei põe o dinheiro aí, aí eu falei num faz isso não. Ele falou me desculpa minha dona... Falou, mas levou... Minha filha não gostava daqui, hoje ela gosta (...).

Antônia: a gente tinha tudo pra viver bem, mas a gente tem que conversar, mas não tem como... Eu tenho 56 anos não sou uma criança mais, eu sei o que eu aprendi, a vida ensina a gente, a vida que ensina. A gente teve uma boa criação, nossa (...).

Orlando: sabe de uma coisa que acho ruim, o meu pai nunca deixou eu estudar, eu falo, ele já morreu mesmo, faz 20 anos, se eu tivesse grau de estudo, se eu soubesse, eu podia tá muito bem na vida, porque tem muita coisa que eu dependo de lê, eu não sou um cara burro, a minha cabeça é um computador... Eu assino, eu entendo de tudo quanto é negócio, de lei eu 
entendo, se for um advogado pra conversar comigo, eu sei, eu sei conversar, o meu patrão me dá uma lista dessa aqui, e fala assim pra mim e pergunta 'quanto deu isso, isso, mais isso', dá tanto, vai bater, aí vai ver deu certinho, dai hora que chega o caminhão só confere a relação e tudo, sai carregando tudo quanto é lugar, conta de cabeça eu faço tudo, eu não sei ler (...). Às vezes a gente tá aqui, mas a gente vê gente que tá pior que a gente..."

Os afazeres do dia-a-dia surgidos no ambiente doméstico se impõem através das relações de gênero que estão em comunicação com a estrutura social. O encontro entre diferentes perspectivas, tanto dentro como fora do mundo doméstico, ocorrido pela divulgação de panoramas além de padrões previamente definidos, faz destes afazeres elucidativos de conflitos criados pelo debate entre as pessoas que compõem o lar, problematizando a estática de representações de conceito de gênero e espelhando a dinâmica social. Ao ser instituído que todos os afazeres domésticos devem ser realizados pelas mulheres, o "simples" marido passa a ser marido-patrão, e por vezes não descartando a possibilidade de ser um pai-patrão, inclusive quando doente, exigindo os cuidados necessários. Uma suposta posição de vítima que choraminga por poder.

Filhos e esposas, na busca por melhores condições de vida (incluído aqui dinheiro e saúde), transformam-se em mercadorias, sendo avaliados por sua utilidade. THOMPSON (1998) diz sobre a venda de esposas na Grã-Bretanha do século XVII em grupos populares, sendo às vezes amarrada e puxada com uma corda ao pescoço e leiloada e passando a fita para o novo dono, simbolizando a posse da corda a mulher como sua propriedade. As vendas das esposas não ocorriam em locais fechados, eram vendas ocorridas no mercado público, a mulher desfilava como um animal puxado pela corda, porém quando vendida ocorria um consentimento público, vendedor, comprador e a mulher declaravam a negociação com ares de uma cerimônia de um novo casamento, mesmo quando a mulher era forçada a esse consentimento, com testemunhas e documentação, formando um ritual popular, não institucionalizado mas aceito:

"O simbolismo era obviamente derivado do mercado de animais, e aqui e ali inventavam-se formas mais elaboradas para confirmar a simulação de que a mulher era um animal. Seria talvez, sob uma antiga forma popular, a brincadeira de passar a perna no diabo (ou em Deus)? Os elementos 
adicionais mais freqüentes eram atar a mulher na cerca do mercado, prendê-la num cercado de ovelhas, fazê-la passar pelos portões do pedágio (de vez em quando, novamente as mágicas três vezes) e, muito freqüentemente, pagar aos funcionários do mercado a taxa pela venda de um animal." (THOMPSON, 1998, p. 317).

A vigilância sobre o comportamento das mulheres é uma norma em diferentes grupos sociais, indo desde sua sexualidade até a eficiência na realização dos afazeres domésticos e, quando se trata de grupos com condições financeiras dificultosas e que querem ascender na hierarquia social, um olhar econômico sobre a capacidade de economizar da mulher se transforma numa necessidade. Algumas falas que encontrei durante a observação participante: "a minha primeira mulher era boa, guardei dinheiro com ela, com essa da agora ela não sabe juntar dinheiro”, "a gente não deveria casar, deveria assinar carteira, quando cansasse era só fazer o acerto”. Contudo, não se devem descartar as imposições das mulheres aos maridos qualificados para corresponder aos seus desejos, como a capacidade de ter e ganhar dinheiro e de manter as condições almejadas, como a construção de uma casa, a compra dos móveis e, quando não ocorre, podem-se notar as insatisfações, como exemplo, lembro o relato de Silvia.

São comportamentos, como THOMPSON (1998) diz, que acontecem socialmente, mas que ganham aspecto de legalidade por serem aceitos e praticados pela coletividade. A venda de uma mulher, quando aceita por esta, também representava sua vontade de mudança, ir para outro lar, dentro da instituição moral da coletividade, sendo também vendidas para seus próprios amantes. Durante a venda, os papéis masculinos também passam a ser questionados, as vendas de mulheres por maridos violentos eram, segundo THOMPSON (1998) aplaudidas, simulando uma falsa liberdade da mulher. Desse modo, como foi possível observar através da pesquisa de campo, os grupos populares desenvolvem normas e mecanismos para o seu cumprimento, fora do âmbito institucional, da legalidade produzida pelo Estado. Na constituição e imposição de normas e mecanismos, ao gerarem conflitos, os medicamentos psicoativos tornam-se auxiliares ora como colaboradores para imposições ora como questionadores. 
ALMEIDA (2004), em seu estudo no início da década de 1990, na aldeia Pardais (com menos de seiscentos habitantes), localizada no sul de Portugal, revela a heterogeneidade contextualizada em que a masculinidade se estrutura, mesmo esta sendo organizada em um modelo hegemônico. As condições econômicas e a força física irão hierarquizar o masculino e promover conflitos entre diferentes concepções do que é considerado masculino. Tanto a masculinidade como a feminilidade estão permeados por relações de poder na busca de definições ideais frente a outras que as ameaçam, por isso se diz masculinidades assim como feminilidades, ambos no plural:

"Masculinidade e feminilidade não são sobreponíveis, respectivamente, a homens e mulheres: são metáforas de poder e de capacidade de acção, como tal acessíveis a homens e mulheres. Se assim não fosse, não se poderia falar nem de várias masculinidades nem de transformações nas relações de género. O carácter móvel e contingente da relação entre masculinidade, homens e poder torna-se claro quando analisamos etnografias que prestam atenção ao diálogo e conflito entre masculinidades hegemónicas e subordinadas, ou que prestam atenção quer à variabilidade individual das identidades masculinas, quer às alterações destas num só indivíduo ao longo do ciclo de vida ou consoante diferentes situações de interacção.” (ALMEIDA, 2004, p. 156).

De acordo com ALMEIDA (2004), a masculinidade está relacionada à força física e com o tipo de trabalho executado pelos homens, assim, o trabalhador braçal enfatiza o corpo considerado forte como modelo idealizado de masculinidade, enquanto os trabalhadores autônomos destacam as "espertezas", capacidade de ganhar dinheiro através do seu próprio negócio. Os trabalhadores braçais apresentam características que passam a definir o que seria a masculinidade, ora mostrando-se fortes e com as mãos calejadas, ora evitando que o corpo transpareça fragilidade frente ao trabalho, não se permitindo o jeito curvado de andar, não deixando o corpo transparecer cansaço e submissão. A hierarquia de gênero se apresenta através da relação capacidade econômica/força física. Estar em uma condição socioeconômica relativamente desfavorável implica em valorizá-la como uma vida dificultosa, revelando seus reflexos através de suas marcas deixadas no corpo como sinal de masculinidade, enquanto: "O poder (masculinizado) é associado àqueles que controlam recursos e que têm interesse em naturalizar e perpetuar esse controlo, 
incluindo esse poder a capacidade de feminizar os subordinados" (ALMEIDA, 2004, p.165). Aos subordinados ou subalternos são exigidos, através do questionamento de sua masculinidade pelos patrões, maior esforço para o trabalho, levando a perpetuar a relação explorado/explorador através da masculinidade. Orlando apresenta a confluência desses dois modelos de masculinidades, ora sendo um negociante, ora um trabalhador braçal, transparecendo o conflito entre estas masculinidades, destacando ao mesmo tempo o seu desempenho e força física e a destreza para os negócios frente aos dois trabalhos, o de fora e o de dentro da casa. Os "nervos" impõem nestes dois ambientes frisando sua masculinidade, que é transformada de acordo com as circunstâncias, funcionário e marido-patrão. Nesse sentido, Orlando une em casa duas partes que se somam para a masculinidade, o marido que cumpre o papel de provedor e do patrão que manda e exige constantes rendimentos de sua esposa-funcionária, exigindo desta uma submissão intensa. O silêncio provocado pela submissão é aqui questionado por sua intensidade, a união com Orlando que representava para Antônia a "autonomia" sobre sua própria casa estaria sendo protestada não pelo cumprimento de uma norma social, mas pela intensidade que é realizada. A mulher que seria possivelmente vista como "patroa do lar" passa a ser "funcionária do lar".

A definição de modelos está também susceptível de uma análise social sobre a biografia das pessoas, definindo como processo de individuação, separando-se de uma suposta homogeneidade social, contribuindo para a formação de estigma de anormais e a predeterminar um padrão de normalidade e representatividade (GOFFMAN, 1988), coagindo ou intimidando outros que distanciam de modelos idealizados. A masculinidade se refere a detalhes como o jeito de andar, vestir, sentar, falar e do que se fala, são maneiras que esclarecem sobre a existência de variáveis de masculinidade, sendo contextualizada através do tempo (gerações), lugares (rural, urbano, periferia, centro), condições econômicas, profissão, etc. Enfim, a masculinidade (como a feminilidade) possuem um habitus (BOURDIEU, 1999). Os grupos populares irão temer não somente um estigma, mas uma variedade, o "juntar tudo" aqui também inclui estigmas. 
Os medicamentos ansiolíticos, ao serem identificados como remédio para loucura, doença psiquiátrica, parecem ser temidos quando comparados aos antidepressivos, considerados mais inofensivos, fracos. A relação remédio forte e fraco se relaciona a especialidade médica, a doença forte exige um remédio forte prescrito pela psiquiatria. Para o pesquisador que tem que transitar pelos espaços de divergências sociais, conflitos marcados por nomeações que estereotipam grupos sociais deve ser vista com cautela, pois além do pesquisador ser confundido com determinado grupo e produzir dificuldades para interagir com outro, pode ser alvo de fofocas na reafirmação de críticas a outros grupos.

As situações conflituosas podem se tornar o objeto da pesquisa envolvido pela presença do pesquisador. Passar por estes conflitos é saber negociar com diferentes perspectivas, sendo necessário ratificar sua posição de neutralidade frente às opiniões divergentes dos diferentes grupos com o intuito de prevalecer a interação pesquisador-pesquisado em todo o campo pesquisado. Os conflitos são destacados em um processo que se revela paradoxal à medida que a sociedade não consegue conviver com as diferenças nas quais o pesquisador está também envolvido, devendo assim analisar a vida social inserida em processos, como diz VELHO (1997):

"Ao se perceber a vida social como um processo, contraditório e complexo, em que a realidade tem de ser permanentemente negociada por diferentes atores, a possibilidade do conflito e da disrupção perde o seu caráter catastrófico e anormal para ser encarada como mais um fenômeno a ser pesquisado. É dentro dessa perspectiva que se pode estudar um sistema de acusações como uma estratégia mais ou menos consciente de manipular poder e organizar emoções, delimitando fronteiras." (VELHO, 1997, p. 57, grifo do autor)

As tarefas oriundas dos moradores de uma casa são impostas às mulheres de grupos populares. O consumo de medicamentos psicoativos contribui para ordenar o trabalho doméstico e combinar este com outros trabalhos fora deste espaço. $\mathrm{O}$ trabalho doméstico pode fazer parte de duas esferas que se combinam para produzir conotação de trabalho desqualificado e de baixo custo, o trabalho gerado pela própria família que não é remunerado e o trabalho remunerado (e geralmente precarizado) quando se realiza em casa de outrem. São trabalhos destacados os de lavadeira, 
passadeira, dona-de-casa, faxineira, arrumadeira, babá, empregada doméstica, cozinheira, cuidadora de doentes, entre outros.

A naturalização dos afazeres domésticos como parte de uma rotina que inclui somente a mulher, que a exclui da vida pública e do trabalho remunerado, leva a sua desqualificação, reforçando uma estática de papéis predeterminados socialmente e facilitando a exploração da força de trabalho da mulher. Assim, o trabalho doméstico se mostra mais susceptível a conflitos indutores de consumo de medicamentos psicoativos por estar representado por esta proximidade com o outro.

O trabalho doméstico pode se organizar através da definição de papéis pelas famílias de grupos populares, centralizados em seus sentidos de reprodução, produção, rendimento e consumo (DURHAM, 2004). Por um lado, ocorre a relação entre Estado e medicina no cumprimento desses papéis, como a união entre norma disciplinar, higienização, urbanização e definições de comportamentos para os diferentes sexos (FOUCAULT, 1984). E, por outro lado, como nos diz DURHAM (2004), a família passou no modo de produção capitalista a ser definida por padrões de rendimentos e consumo somados individualmente entre seus componentes. A família, sendo reprodutora de força de trabalho, responsável pela sobrevivência dos novos e velhos trabalhadores, dita necessidades e modos de vida e, conseqüentemente, do que se irá consumir, unindo afazeres domésticos com o fornecimento de força de trabalho ao mercado. A família, além de se mostrar através de valores e representações, revela-se na produção das condições materiais de vida, definindo, de acordo com rendimentos, o que se consome e o modo de preparar-se para este consumo, implicando gastos com o bem-estar, vestuário, alimentação, habitação, móveis, eletrodomésticos, escola, assistência médica, profissionalização, entre outros: "Cozinhar, lavar, passar, remendar, cuidar das crianças são todas atividades que não produzem mercadorias, mas que permitem sua utilização enquanto valores de uso e são indispensáveis, a curto e a longo prazo, para a reposição da força de trabalho consumida no processo produtivo" (DURHAM, 2004, p.243). 
A família, encontrando-se na construção da vida, organiza valores, produz representações, (re)elabora interpretações sobre a vida, produzindo experiências, fazendo do cotidiano um mundo que correlaciona o presente imediato com o passado, com as memórias, reconhecendo o sentido dinâmico da vida (DURHAM, 2004). O (re)significado dado aos medicamentos psicoativos por nossas entrevistadas revelam como a interação de seu cotidiano e de suas condições socioculturais com os serviços de saúde é tênue. O medicamento também passa a ser preparado pela família para ser consumido, elaborando conhecimentos sobre os medicamentos e os modos de uso, promovendo a manipulação do corpo.

Além disso, como se observou, os medicamentos psicoativos são utilizados tanto para amortecer conflitos internos no lar (gênero, de classe social, geracional, etc), como os surgidos entre este e seu exterior, conflitos estes que produzem questionamentos e mudanças. Podem-se citar os oriundos das questões referentes ao trabalho da mulher fora de seu espaço doméstico e a queda do "conforto" dos maridos, de não encontrar, por exemplo, o jantar e o seu corpo disposto e sorridente a sua espera, e aos resultantes da sobrecarga de trabalho em que estas mulheres se encontram ao terem que realizar também os afazeres domésticos da família, exigindo delas mais disciplina, rapidez, eficiência. A relação entre consumo de medicamentos e cotidiano está assim orientada pela ocorrência de conflitos, colaborando no modo de consumo dos medicamentos e na aderência às prescrições médicas.

O uso dos medicamentos de acordo com as prescrições médicas envolve um contato de diferentes perspectivas, de um lado a do paciente e do outro a do médico, ambos revelando conhecimentos e saberes diferentes. Assim, o consumo de medicamentos envolve conhecimentos e experiências com doenças, com os medicamentos, gerando concepções sobre os tratamentos de acordo com a vida cotidiana. LEITE e VASCONCELLOS (2003), em estudo de revisão, destacam alguns fatores que levam a não adesão aos tratamentos prescritos pelo médico: como o custo dos medicamentos, número de medicamentos prescritos, tipo de esquema de tratamento ou modo de uso considerado complicado, incompatibilidade entre rotina dos usuários de medicamentos e o modo de uso como o horário, a relação quantidade 
dos medicamentos com qualidade, falta de confiança nos tratamentos prescritos e no profissional prescritor, quando o paciente não se aceita doente, consumo de acordo com a relação sintomas da doença/efeitos dos medicamentos e não de acordo com os horários prescritos, o tipo de doença para que o medicamento é prescrito, efeitos dos medicamentos, resultados esperados do tratamento e sua relação com o tempo de uso.

MALPASS e col. (2009), em estudo de meta-análise de pesquisas qualitativas sobre o consumo de antidepressivos, investigaram o porquê da não adesão aos tratamentos, fazendo uma diferenciação entre aceitação dos antidepressivos relacionados aos conhecimentos prévios dos pacientes e aos conhecimentos adquiridos após o início do tratamento e sua relação com estados do corpo considerado sadio e doente, o que, segundo os autores, leva o paciente a redefinir o medicamento de acordo com o tempo de tratamento devido à reformulação de seus conhecimentos sobre os medicamentos. A experiência com antidepressivos podem levar o usuário a desenvolver novas estratégias de uso, como mudar a dosagem diária, parar de tomar por um período de tempo, associar com outros tratamentos. Estes autores enfatizam a necessidade de um maior diálogo entre serviços de saúde e paciente, verificando os significados dados aos medicamentos, pois estes poderão interferir no modo de uso, levando a não aderência, alertando para um diálogo entre médicos e pacientes sobre estes conhecimentos com o intuito de evitar o abandono dos tratamentos ou o uso diferente do prescrito.

Assim, o caminho ou curso que o paciente faz leva a modificação sobre o tratamento. Os acontecimentos no dia e no decorrer da vida das pessoas que entrevistei, como a ocorrência de morte, dificuldades econômicas e a interferência da religião, colaboram para que os medicamentos adquiram um novo sentido. Somando às imprevisibilidades do dia-a-dia, os medicamentos são avaliados de acordo com a relação corpo/efeitos dos medicamentos. Os medicamentos são interpretados pelo usuário, não ocorre uso como uma ordem, como a prescrição médica tende a ser. $\mathrm{O}$ usuário de medicamentos psicoativos reavalia seus efeitos e os utiliza de acordo com os conflitos que circulam sua vida. 
Observa-se que o envelhecimento, somado às condições de classe popular e de gênero, é também um fixador da mulher no espaço doméstico, perpetuando e até intensificando o seu trabalho, reafirmando os afazeres domésticos como não trabalho, misturando uma relação familiar com exploração. O trabalho doméstico visto nessas condições pode ser alvo de acúmulo quando várias tarefas se somam, como o cuidar de doentes, cuidar dos filhos, cozinhar, passar, lavar, outros trabalhos fora de seu próprio ambiente doméstico. Estas situações nem sempre se apóiam em uma rede de solidariedade entre os membros de uma família, direcionando o papel de cuidador a uma única pessoa. Entretanto, não se pode descartar a possibilidade de existência de laços solidários como os na família ou entre vizinhos da casa do doente. Além disso, os afazeres domésticos, ao não serem vistos como trabalho, possibilita também uma exploração infantil silenciosa que se estende pela vida, contribuindo para uma menor preparação escolar e para o mercado de trabalho.

Segundo BRUSCHINI (2006), as donas de casa são apresentadas erroneamente pelos levantamentos estatísticos do PNAD (Pesquisa Nacional por Amostras de Domicílios) do IBGE (Instituto Brasileiro de Geografia e Estatística) como inativas economicamente e não como executoras de trabalhos nãoremunerados, desconhecendo o elevado número de horas na sua execução. De acordo com a autora, o PNAD define afazeres domésticos como a execução de tarefas relacionado ao lar e aos seus moradores, como arrumar, limpar, cozinhar, passar, cuidar de filhos ou menores moradores. Questiono este conceito pela falta de ênfase aos cuidados às pessoas doentes, que como foi observado encontra-se na mesma condição de exploração e invisibilidade, principalmente nos grupos populares.

Observa-se que cuidar de doentes envolve grande dedicação, como foi notado em algumas de nossas entrevistadas com filhos doentes, marido, pais, cunhados. Este cuidar não envolve somente uma dedicação quando o doente se encontra dentro do lar, ele está relacionado ao enfrentamento de longas filas dos serviços públicos de saúde na procura de atendimento médico, na aquisição de medicamentos. O ser cuidador envolve também uma relação de gênero na qual são as mulheres que geralmente exercem essa função, escolhendo e aconselhando tratamentos (itinerário 
terapêutico), orientando o horário e as situações em que devem fornecer os medicamentos ao doente, aplicando sua experiência de cuidadora do lar, em um sentido higiênico, como os relacionados à limpeza da casa, das roupas, dos filhos e da preparação dos alimentos, a união com saberes adquiridos nas suas idas e vindas aos serviços de saúde. É bom lembrar que a função de cuidador envolve desgaste físico e emocional, precisando de força física para dar banhos, carregar o doente, segurar, entre outras, e envolvendo também desgaste emocional devido ao sofrimento de quem é cuidado, a morte, as noites mal dormidas, etc.

Os dados do PNAD/2002 mostraram, de acordo com BRUSCHINI (2006), que a média de horas por semana dedicada com o trabalho doméstico foi em média de 10,6 horas para os homens e de 27,2 horas para mulheres, ocorrendo, para estas, um aumento com a idade, principalmente depois dos 25 anos (28,7 horas), chegando a 32,9 horas entre 50 e 59, e 36,6 horas depois dos 60 anos de idade, enquanto para os homens foram de 14 horas depois dos 60 anos. Apesar de os homens, quando ficam mais velhos, aumentarem proporcionalmente as horas de dedicação aos afazeres domésticos, eles ficam muito longe de chegarem a uma proximidade de dedicação das mulheres. Outro fator encontrado: o número de horas diminui à medida que aumenta a escolaridade. As mulheres acima de 12 anos de estudo ou com curso superior trabalham em média 9 horas a menos com afazeres domésticos do que as que estudaram de 1 a 4 anos (29 horas). Observou-se persistência de diferenças de gênero: apenas $38 \%$ dos filhos declararam realizar afazeres domésticos em comparação aos $80 \%$ das filhas, dedicando uma média de 17 horas, quase o dobro dos homens. O fato de ter filhos também mostrou elevar o número de horas de dedicação, 31,9 horas semanais contra 18,2 de mulheres sem filhos. Além de outros fatores discutidos, as mulheres pertencentes aos grupos populares, quando com primeiro grau incompleto e maior número de filhos, tornam-se mais susceptíveis à alto número de horas de dedicação aos afazeres domésticos (BRUSCHINI, 2006). 

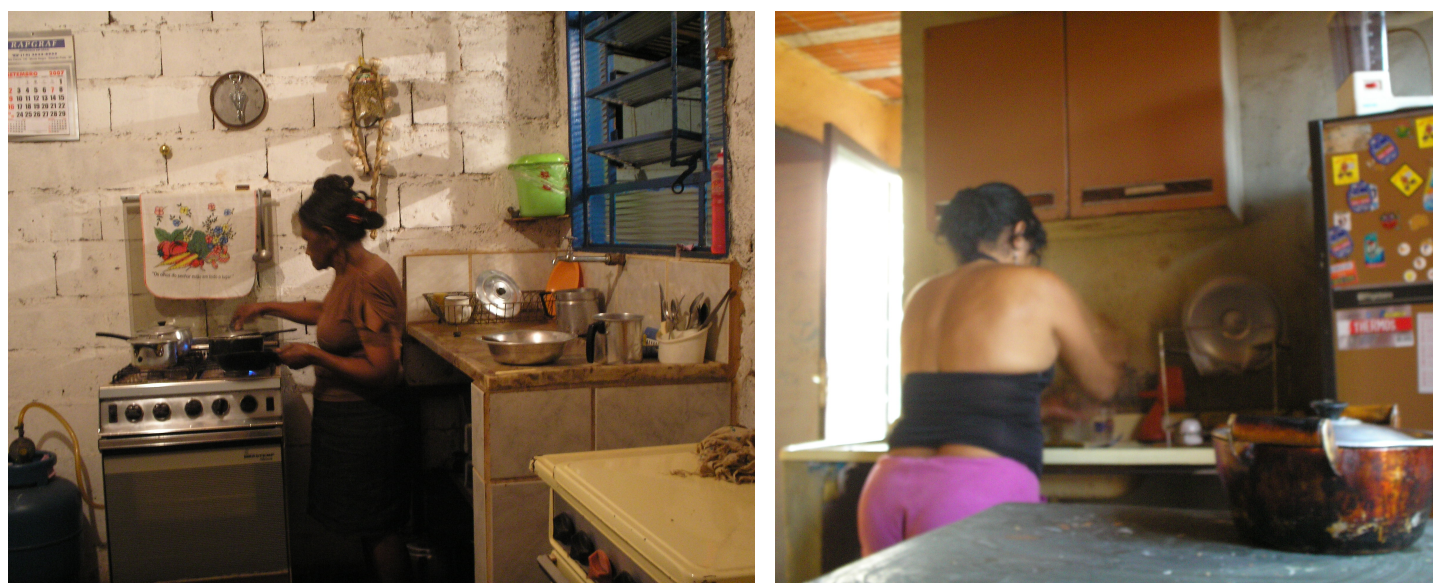

De acordo com BRUSCHINI (2006), reconhecer os afazeres domésticos como trabalho proporcionaria seu distanciamento do sentido de favor, de cortesia. Podem-se citar as inúmeras mulheres, às vezes crianças, de grupos populares que são "acolhidas" por famílias para serem empregadas domésticas e exploradas em nome de uma suposta ajuda, recebendo seus salários como favor ou por vezes não o recebendo em troca de moradia e alimentação.

Para KOFES (2001), em pesquisa realizada com empregadas domésticas e patroas na cidade de Campinas, no final da década de 1970, a condição de empregada doméstica expõe um encontro entre diferentes e (des)iguais em um espaço privativo - o doméstico -, marcado por disputas, confrontos, proximidades e distâncias, lugar definidor de identidades de patroas e empregadas, visto a partir de uma perspectiva que passa por conotações de termos, envolvendo relação com família e afazeres domésticos. O doméstico, segundo KOFES (2001, p.92), está caracterizado por: "um conjunto de atividades; a casa, enquanto espaço compartilhado, para a 'vida familiar', as atividades cotidianas da reprodução; a relação política de 'domesticar' (trazer para certos termos culturais o que deles difere); a trabalhadora, e até designa as atividades daquelas que as executam sem assalariamento ('prendas domésticas')"”.

Em sua pesquisa, KOFES (2001), observou que as patroas denominam empregadas de máquinas, robôs, quase da família, auxiliar do lar, enquanto as 
empregadas, reafirmando-se como pessoa, trabalhadora e, com ares de negação de sua condição e do termo que diz, pronunciam-se como escravas e máquinas. A autora mostra como as empregadas domésticas passam por um processo de disciplinarização (tanto por parte das patroas como através de cursos oferecidos por instituições religiosas ou pelo Estado), em um sentido que coloca a definição do próprio termo "doméstico" como real, o sentido de amansar, civilizar, domesticar, colocando a empregada submissa aos padrões elegidos pelas elites. Um ambiente definido como feminino passa a definir diferenças e desigualdades entre as mulheres, destacando patroas e empregadas. A autora mostrou um lado excludente dentro da própria casa onde trabalham. Quando dormem no trabalho, notou-se que os quartos não passam de dispensas, sem ventilação e espaço apropriados. Nos cursos e agências de empregos, são exigidas das empregadas atitudes relacionadas à servidão frente aos comandos das patroas, obediência, higiene, vestuário, cuidados com o corpo, "com boa aparência", calma, afável e alegre, "comportada", experiente, educada, competente, pontual e "de caráter".

É através dos afazeres domésticos que se podem aprofundar as questões simbólicas relacionadas à exploração de uns sobre os outros, questões que passam como invisíveis. Assim, os afazeres domésticos são ignorados pelas teorias econômicas e não são contabilizados no Produto Interno Bruto (PIB) dos países. É sobre esta perspectiva que MELO e col. (2007), aconselhando a inclusão dos afazeres domésticos no PIB, constataram através de dados fornecidos pela PNAD, que entre os anos 2001 e 2005 o tempo gasto nas tarefas domésticas e sua relação com o salário em média recebido quando executado de forma remunerada, no Brasil, correspondiam anualmente a cerca de $11,2 \%$ do PIB nesse período. Os serviços domésticos, executados quase em sua totalidade por mulheres pertencentes às camadas populares, quando realizados dentro de suas próprias casas, não são considerados como força de trabalho, somente quando realizados por terceiros. Para os autores, uma das formas de diminuir a discriminação sobre as mulheres é o reconhecimento dos afazeres como parte do PIB, tornando o trabalho visível e revelando sua contribuição ao bem-estar familiar e do país. 
Acrescento que existe um mercado consumidor com grande dispêndio de capital na compra de equipamentos e eletrodomésticos para execução das tarefas domésticas. São nesses afazeres que hábitos culturais se mostram através do modo de cuidar do filho, de doentes, de preparar os alimentos, entre outros. A própria relação entre consumidor e vendedor desses produtos confirma a dissimulação desses afazeres como trabalho, como dispêndio que evita a cada momento outros inumeráveis afazeres fora desse contexto. Esses produtos são comprados como presentes, sendo alvos mercantis em dadas comemorativas específicas das mulheres, como os anúncios de promoções nas lojas de eletrodomésticos no dia das mães. Essas condições apóiam rotineiramente propagandas de equipamentos utilizados na cozinha com o intuito de facilitar a vida dessas donas-de-casa, indo desde os alimentos, que são preparados mais facilmente ou em tempo reduzido, até o vestuário e eletrodomésticos agregados de tecnologias inovadoras. Ironicamente, são tantos presentes em uma sociedade capitalista e excludente para pessoas consideradas inativas.

ARAÚJO e SCALON (2006), trabalhando os dados de uma pesquisa realizada no Brasil através de survey realizado pelo International Social Science Program no ano de 2003, procurando compreender a dinâmica social entre vida familiar e trabalho pago, verificaram que as tarefas domésticas são concebidas por ambos os sexos como parte da vida das mulheres. A existência de modificações decorridas do aumento de inserção das mulheres no mercado de trabalho não retirou da mulher o papel de principal cuidadora, sendo a mulher quem quase sempre cuida das crianças (vestuário, dar banho, dar comida, acompanhamento nas atividades escolares, levar ao médico, brincar).

Segundo a pesquisa de ARAÚJO e SCALON (2006), são as mulheres quem em sua maioria lavam, passam, cuidam de doentes, cuidam da comida, limpam a casa e vão ao banco pagar as contas. Além disso, a maioria considera que a intensa participação nos afazeres domésticos não é injusta, e que mais da metade dos homens e pouco menos da metade das mulheres concordam com divisão que coloca o homem como provedor financeiro e a mulher como cuidadora do espaço doméstico, 
mostrando a permanência de um modelo dual acoplado de um significado do trabalho remunerado da mulher como auxiliar. Contudo, de acordo com os autores, os dados supõem mudanças significativas, mas que ainda se apresentam arraigadas a uma estrutura social machista, mesmo com a presença do trabalho remunerado das mulheres.

A própria relação "amorosa" do casamento procura aliar afazeres domésticos com sexualidade, incluindo-os nos "dotes", servindo como parâmetro para avaliar as "boas" mulheres, afirmando uma aproximação considerada ideal de gênero. Este comportamento não é homogêneo, sendo diferente nos grupos sociais, variando entre o mandar fazer e a execução dos afazeres, buscando um padrão de perfeição. Ocorre uma constante avaliação como estratégia de poder colaborada, além de por familiares na manipulação de comportamentos, pelos receituários médicos, livros e revistas de etiquetas. Soa como contraditório a imposição de todos esses afazeres domésticos ser construída em conjunto com uma noção de mulheres como frágeis em oposição à "fortaleza" dos homens, fazendo reafirmar que os afazeres domésticos são fáceis comparados ao que os homens "sofrem" em seus trabalhos. O casamento poderia representar um favor, principalmente àquelas que fugiam das normas impostas de comportamentos, de sexualidade e de idade para o casamento. As coerções na fuga dessas normas iam desde uma expulsão dos lares até o enclausuramento em instituições religiosas e psiquiátricas.

Nesse sentido, algumas mulheres, ao revelarem a honra como construção social, procuram expor com orgulho suas casas organizadas e limpas, as roupas bem passadas, o arroz com feijão maravilhoso: os elogios, nas reuniões familiares e de amigos, no domingo na hora do almoço, em festas comemorativas como aniversários, dia das mães, natal. Além disso, as reuniões de amigos como as deliciosas feijoadas, nas peixadas, nas galinhadas. Ocorre assim uma busca por aperfeiçoamento constante, disciplina sutil e internalizada não só com lágrimas, mas com sorrisos simpatizantes e, às vezes, recheados de sugestões culinárias. Não se pode esquecer as possíveis avaliações, o bastante para alguns questionarem a eficácia feminina é o olhar sobre filhos considerados indisciplinados, a comida ruim, a roupa 
suja e mal passada, os doentes com aparência de mal cuidados, tristes. Somando a estes afazeres, pode-se observar a aliança que se tem com a higiene, os cuidados fornecidos pelos manuais sanitários, incluídas numa gama de conhecimentos interdisciplinares, envolvendo saberes sobre nutrição, medicina, enfermagem, psicologia, farmácia, etc.

É bom lembrar que as explorações são muito bem eficientes quando trabalho não é percebido como trabalho, é visto como favor ou uma obrigação naturalizada, e o salário é transformado em ajuda, em preço simbólico. O mercado de trabalho fora do ambiente doméstico não ignora as qualificações adquiridas no ambiente doméstico pelas mulheres, em uma situação atual onde as relações de poder se organizam para uma produção de mercadorias, podendo negar ou reafirmar ou criar novos preconceitos e discriminações, quando conveniente, desde que haja colaboração para o consumo e a produção. Assim, as mulheres são chamadas, dependendo da ocasião, de incapazes e frágeis para o trabalho ao mesmo tempo em que são vistas como ótimas trabalhadoras, detalhistas, pacientes, precisas, resistentes à monotonia de alguns trabalhos, ocorrendo um aproveitamento do que chamam de inato e natural e excluindo de uma lógica de qualificação e competência.

Apesar de todas as mudanças ocorridas no mundo do trabalho, como a crescente inserção das mulheres no mercado de trabalho, segundo BRUSCHINI (2007), ao comparar dados dos anos de 1993 e 2005, verificou elevado número de desemprego de mulheres e predomínio em atividades precárias e informais. Além disso, a autora relata o predomínio de modelos tradicionais como a alta concentração das mulheres em serviços domésticos (mais de 90\% destes serviços são executados por mulheres), sendo pouco alterados nesse período, até aumentando quando comparados aos homens, passando de 16,6\% de todas as mulheres ocupadas em 1993 para $16,93 \%$ em 2005, contra, respectivamente, $0,7 \%$ e $0,9 \%$ dos homens. A maioria das mulheres (96\%) recebiam até 2 salários mínimos e somente $25 \%$ possuíam carteira assinada. Além disso, a autora mostra que o perfil da mulher com carteira assinada se concentra nas mais velhas, casadas e com filhos, ocorrendo sobrecarga ao centrar tanto no trabalho quanto na família. 
Prevalece situação em que as mulheres de grupos populares são susceptíveis de serem vistas como auxiliares gratuitas. Pode-se ver no dia-a-dia a extensão do trabalho ou agregação de outros afazeres além do seu quando estas executam trabalhos remunerados: não é incomum trabalhadoras domésticas ficarem mais tempo no trabalho, serem "emprestadas" para outros, fazerem, além de suas funções, outras como a limpeza de outras salas, de equipamentos, um "passar ali pra mim quando for embora", um “aproveite e faça isso pra mim".

O trabalho doméstico pode ser visto como produto final de um processo de alienação iniciado na formação familiar, coagido a exercer comportamentos e normas que afirmam trabalho excedente, não pago e disciplinado na própria formação, e explorado nessa condição de gênero. E esta condição pode ser expandida pelos diversos setores de trabalho em que se encontram as mulheres. Exigindo assim uma qualificação pela via cultural, via familiar, via de habitus, uma qualificação sóciohistórica construída. Além disso, quando estes afazeres são remunerados, ganham conotações pejorativas, má remuneração e aumento do tempo de trabalho. Ligado a estes trabalhos, pode-se citar uma rede de serviços disponíveis nas cidades, que partem das experiências dos afazeres domésticos, como as creches, os restaurantes, lavanderias, padarias, asilos, cabeleireira, abrigo para idosos, etc, e que fazem parte também da institucionalização de profissões universitárias como os cursos de economia doméstica, gastronomia, nutrição, entre outras.

Pode-se ilustrar esta situação com a profissão médica. Em pesquisa realizada por MACHADO (1997), encontrou-se que as especialidades médicas mais escolhidas pelas mulheres são as relacionadas ao espaço doméstico como pediatria, nutrologia, dermatologia, clínica geral, as quais apresentam menores rendimentos financeiros do que as outras especialidades mais "masculinizadas". A esse respeito, MACHADO (1997) nos diz que, além do gênero influenciar na escolha de sua especialidade médica, elas procuram especialidades que tenham horários mais flexíveis devido à necessidade de maior permanência em casa, com filhos, e de administrar sua casa, fazendo, assim, não entrarem em esquema de plantão, tendo então salários reduzidos se comparados aos dos homens. O espaço interno da casa estaria assim contribuindo 
para perpetuar explorações e domínios, principalmente quando o trabalho doméstico não é visto como complemento de outros trabalhos.

Os medicamentos psicoativos aqui são utilizados tanto como apoio aos serviços domésticos quanto manipuladores de uma condição de subalternidade das mulheres. Além disso, não se poderia restringir os efeitos de outros medicamentos, pois são uma grande variedade de substâncias farmacológicas que colaboram na busca de ultrapassar limites do corpo através de um parâmetro de produção, da hierarquia crescente de cotas a cumprir. Como exemplo, pode-se citar o uso de antiinflamatórios comprados em farmácias, fortificantes, medicamentos para conter o sono, fazendo doenças e problemas sociais se tornarem invisíveis e perderem tonalidade relacionada ao trabalho e a questões sociais. São medicamentos de uso imediato, que silenciam o corpo frente às explorações de classe, construindo socialmente performances e limites insuportáveis, buscando constante recorde de produção. Nesse sentido, o medo de ser julgado como fracassado devido à perda do emprego se impõe como norma que questiona o sentido de utilidade da pessoa. Este medo foi encontrado nos entrevistados, esclarecendo que esta condição de exploração da mão-de-obra é também vista internamente nos lares, possivelmente antes mesmo de surgirem discussões sobre trabalho numa esfera global.

Os afazeres domésticos estão em nossa perspectiva interligados com o mercado consumidor, na preparação de novos consumidores e da idealização do que irão consumir. A estrutura familiar está assim condizendo com este mercado, sendo variável nas suas inúmeras formas de apresentar e de se definir, pois não se buscou homogeneizar a família, são famílias diferentes como cada uma a que pertenciam as entrevistadas.

Muitas vezes, os filhos se tornam ajudantes desde muito pequenos. Os afazeres domésticos se relacionam continuamente com outros trabalhos, ditando não somente o tempo que as pessoas ficam longe dos lares, mas também definindo o que irão levar para sua casa, muitos levando inclusive outros trabalhos e fazendo os afazeres domésticos ganharam uma nova conotação e extensão. São aqui os exemplos em que trabalhadores terminam de fazer seus "afazeres" do trabalho em 
suas casas, ou quando serviços terceirizados são executados na própria residência, ou quando autônomos, fazendo toda a família participar das atividades.

Procuro não definir as pessoas que entrevistei como pertencentes a um modelo ideal e homogêneo de família, visto que eleger qualquer modelo frente a este universo tão variável e mutável estaria favorecendo um tipo considerado ideal frente às relações de poder, incorporando coerções. Mas pode-se interrogar como surgem padrões de família, que propagam seu modelo organizado em detalhes considerados perfeitos pelo grupo e apresentado como se suas uniões fossem possíveis e reais, fazendo uma utopia dinâmica, em que sempre soma algo desse padrão aceito pelo grupo. Padrão que se mistura com conceitos de qualificação e disciplina.

É na composição desses afazeres domésticos que o sentido de utilidade se destaca, apresentando como cooperação entre as pessoas que compõem o lar e fazendo transparecer as relações de poder e exploração. Ficar doente estaria aqui abalando estas relações e posições pré-orientadas, a família estaria em risco. Algumas das pessoas entrevistadas se mostraram ser sempre fortes, úteis, além de preocupadas de ficarem desempregadas e não conseguirem cumprir os papéis definidos tradicionalmente e no provimento de sua família.

BOLTANSKI (1984) mostra que tanto as mulheres como os homens dos segmentos populares são mais resistentes para procurarem serviços de saúde do que as classes com melhores condições financeiras. A este respeito o autor levanta dois pontos, um relacionado às coerções cotidianas e econômicas que torna o abandono das tarefas e trabalhos mais difíceis, outro relacionado a uma construção social, a um habitus (BOLTANSKI, 1984; BOURDIEU, 1999).

O trabalho doméstico se distancia assim como norma natural e se revela como construção histórica e social relacionada ao gênero. Como se vê, as estatísticas demonstram a determinação desse trabalho sobre a mulher, o qual se revela como ordem social imposta. Nesse sentido, a mulher é vista como corpo naturalizado para os afazeres domésticos, relacionando sexualidade e maternidade ao domínio masculino e ao espaço doméstico. A construção de comportamentos, modos de vida, posturas, gestos, linguagens, receios e culpas, compactuados com esta construção 
histórica e social, ao se mostrarem como habitus, são internalizados no corpo e autoexigidos (BOURDIEU, 1999). De acordo com este autor, seria a mulher pedra angular na harmonia da família, a sua integração, cuidar dos filhos e educá-los. Uma suposta separação entre espaços considerados de negócios para os homens e espaço doméstico, do lar, para as mulheres fizeram estas se distanciarem do que se remunera, levando seus trabalhos, quando encaixam nesse ambiente, a serem vistos como naturais, e as mulheres que se situam no espaço público como desviantes, transgressoras de normas e dignas de punição. Algumas entrevistadas relataram a associação entre fixação no trabalho doméstico e as imposições familiares somadas às dificuldades econômicas e de qualificação profissional, contribuindo para formar um habitus que as identificavam como donas-de-casa. Os medicamentos psicoativos estariam aqui colaborando para a persistência desta situação subalterna da mulher de grupos populares.

Numa relação com o ambiente doméstico, o corpo é também comparado. Os cuidados com a higiene da casa são muitas vezes vistos como aprendizado, sendo utilizados nos cuidados aos doentes. Nesse sentido, cada cômodo da casa representa uma sessão de limpeza, de cuidados, de higiene que são refletidos nos cuidados prestados aos doentes, aos filhos. São noções que passam por conhecimentos médicos e de experiência diária.

A dominação masculina implica não só privilégios, mas também deveres, obrigações socialmente consideradas masculinas, o que pode gerar sofrimentos (NARDI, 1998; BOURDIEU, 1999). A doença passa a ser vista como fracasso, insuficiência, como já foi mostrado através dos homens entrevistados, por isso ficar em casa produz sentimento de culpa devido à doença ser definida como insuficiência (EHRENBERG, 1995).

Para os grupos populares, muitos de origem rural ou de pequenas cidades, que chegam às grandes cidades em busca de melhor qualidade de vida, porém os ganhos financeiros não são suficientes para possuírem uma casa, às vezes por gerações, podendo os filhos julgar os pais, principalmente o pai, por não terem conseguido comprar uma casa e dar uma vida considerada melhor. Os pais podem se dizer 
insuficientes, não disciplinados, a mãe culpa o marido, o homem carrega historicamente a culpa por não ter realizados os sonhos de irem para um lugar e alinhar aos projetos de progresso econômico. Assim, a entrevistada Silvia condena o marido por não ter realizado este sonho, enquanto Antônia sente o peso de sua realização e questiona os desgastes que grupos populares sofrem para adquirir uma casa popular. Antônia descobre que toda uma qualidade de vida é subtraída, regrando persistentemente os gastos com a vida diária, com alimentação, moradia, lazer.

A casa simboliza uma conquista de gerações, decorre daí um ponto primordial para ser tão valorizada, tão cheia de poder, tão cheia de conflitos. Os esforços de Orlando para comprar a casa não ficam restritos ao ambiente familiar, possui uma conotação social em um ambiente onde poucos possuem uma casa, possuir uma casa revela um processo de distinção e coerção daqueles que a possuem sobre o morador da favela, "sem casa". É a servidão de Antônia que Orlando quer ter como prêmio ao se considerar detentor da compra da casa, do dinheiro, dos negócios. Porém, Antônia resiste e diz que a vida não pode se resumir ao dinheiro e à casa. A casa para Antônia deve ser posta em um lugar que possui raízes, ser pessoal, a casa deve participar de uma condição sociocultural de sua vida, não deve ser uma casa que a tire de suas relações familiares passadas, a casa deve carregar um passado. Antônia não quer se reduzir ao presente, carrega sua história, enquanto Orlando quer o futuro, o progresso contínuo e se consumir através do tempo à medida que economiza dinheiro e termina de construir a sua casa. Passado, presente e futuro interligam-se ao mesmo tempo em que revelam seus conflitos, o progresso econômico desejado por gerações se debate com a dinâmica social, o progresso relacionado a toda a uma estrutura social, totalidade da cidade e do meio ambiente, com o uso de tecnologias que procura a todo instante destruir o que é considerado velho e construir o novo (BERMAN, 1986) parece não permitir aos grupos populares o construir individual, pessoal.

A relação construir-destruir em que grupos populares estão envoltos manifesta-se sobre toda a sociedade, que beneficia o consumo imediato e não a construção de sonhos ou desejos geracionais. O corpo aqui se transforma em objeto 
de consumo pela estrutura social, a vida se mercantiliza. Os esquecimentos nem sempre são possíveis, o passado questiona o presente, gera angústias, tristezas, decepções. São corpos que juntam marcas de um passado não realizado, que se movimentam entre diferentes regiões em busca de seus sonhos. Por isso, a cidade, quando vista como progresso, é desejada. Ribeirão Preto, ao ser destacada como próxima desse progresso com suas pesquisas científicas, com os tratamentos médicos, sua agricultura mecanizada, entre outros, faz uma emboscada para aqueles que sonham com uma vida melhor, pois são estes que levarão o corpo a desempenhar o máximo de sua produtividade, levando a conciliação entre exploração capitalista e produção de força de trabalho. O corpo não suporta, alguns poucos são considerados vencedores, pois conseguiram suas casas. A família se desespera, fica ansiosa, deprimida e se desgasta como trabalhadora e conflitos são desenvolvidos, procuram o culpado e ocorrem condenações.

As uniões, estando cheias de conflitos, são às vezes mais valorizadas do que os desencontros, quando o casal se separa ou um dos cônjuges morre. Telma (34 anos e com seis filhos) se refere a uma série de conflitos e desgastes devido a morte de seu marido. Telma se vê como a única pessoa que poderia ser considerada culpada pelos conflitos envolvendo sua família, por não considerar que exerceu o papel de mãe. A morte de cônjuge pode significar um deslocamento da relação masculino/feminino e unir papéis que Telma supunha não ser seus, por isso diz ser mãe e pai:

"Eu tenho um quadro de depressão, é estresse no trabalho, tenho problema com filho, porque eu sou mãe e pai ao mesmo tempo, então, junta tudo essas coisas. Sou operadora de maquina (...), lá eu trabalhava muito 12 horas, então foi acumulando estresse com problema de família... problema com filho adolescente, indo pro caminho errado,... pelo caminho de crime, então aí... junto tudo essas coisas na cabeça da gente.... então... a gente fica louca (...) Graças a Deus agora eu tô ótima, depois de tanto antidepressivo (...). Tem um (filho) que tá enjaulado, mas graças a Deus a cabeçinha dele já mudou completamente, em nome de Jesus que ele vai pegar um caminho certo, o caminho que eu ensinei, que ele foi educado. Eu me sentia muito culpada pelos erros dele, porque a minha vida inteira foi trabalhar, só trabalhei, trabalhava em dois serviços e eles foram criados assim, sempre trancado, devido eu ter que trabalhar à noite, sempre trabalhei à noite e de dia um olhava o outro, então foram criados praticamente trancado, isolado 
do mundo, a hora que eles pegaram uma idade eles já foram pro caminho errado. Fiquei depressiva, só chorando (..), devido a consulta com o psiquiatra, com o psicólogo eles foram me alertando, eu me sentia tudo culpada, porque eu sou viúva há 10 anos, o pai deles faleceu (...).

\subsubsection{Quando a casa “cai”: o conflito vira violência}

Nas condições envolvendo agressões contra mulheres, os medicamentos psicoativos podem funcionar também como simuladores de harmonia ao esconder os conflitos envolvendo gênero: inibe resistências através de uma espécie de véu químico, que a deixa invisível e a esconde, despolitiza, silencia. Os conflitos sociais envolvendo grupos populares e toda a sociedade são silenciados com o consumo de medicamentos psicoativos, contudo, os conflitos existentes no espaço interno das casas passam por processo semelhante, envolvendo relações de poder e resistência. Todavia, os conflitos precedem de uma situação liminar, levando às vezes à violência, tanto no meio social, muitas vezes exercida pelo próprio Estado, como no espaço doméstico. É uma violência que afirma ou resiste ao poder imposto aos grupos populares. Os medicamentos psicoativos podem funcionar como aparato "passivador", que induz a aceitação das imposições ao se dizer pacificador. Os medicamentos psicoativos e a religião se unem para impor normas, se mostrando como competidores para imporem um mesmo desejo, a aceitação de sua condição social e de gênero, como foi possível verificar através da entrevista de Isaura (42 anos, 3 filhos), revelando uma disputa entre religião e ciência. O uso dos medicamentos psicoativos se restringe às situações de ocorrência de agressões pelo marido, quando estas não ocorrem, a religião é considerada por Isaura suficiente para não consumir os medicamentos:

"Tomo o fluoxetina. Não o diazepam a doutora me prescreveu dez dias, mas mesmo assim eu não tomei os 10 dias, não, não, não tomo isso não, Deus me livre... Eu tenho um outro que tô tomando, uma amiga minha me deu tem 
uma semana (...). Tomo 4 comprimidos 'oh faz tempo'(...) Assim, dá reação, não posso tomar não, o antidepressivo não me dá reação, oh, esse que minha amiga me deu nem não é diazepam, é um outro, ela me deu porque eu não tava legal, tomei uns dois ou três (mostra duas caixas de antidepressivos diferentes, um a amiga tinha dado). Esse aqui dá sono... tomo dois (fluoxetina) todo dia dois, se toma um não faz efeito. Há com o tempo eu fui melhorando (...) eu parei, né, eu dei uma parada por causa da pressão alta, dei uma parada de 4 mês e ai não sei porque deu esses problemas aí, que eu comecei a tomar de novo. Ai peguei no clínico porque eu tinha parado de ir na consulta com o psiquiatra (...). Foi problema de separação, num sei, faz dois meses que separei. A gente tá bem, assim longe, a gente tá junto, agora morar junto não... Nosso problema mais é bebida, ele e eu bebe, bebe cerveja só, mas tem dia que eu não bebo, aí ele bebe todo dia que ele sai do serviço, e já vai pro bar, aí ele chega bêbado atacando, ele ataca, ele não ataca o filho, ataca eu, quebrando as coisas, ai é díficil, quando eu bebo eu não brigo, eu saio pra rua, pra rua não quero, fico pra rua, quero dançar, mas ele briga, ele briga. (...). Minha depressão, vai fazer 27 anos que começou isso, ...não sei se é hormônio... Porque eu entrei na menopausa com 35 anos, começou a menopausa e já... (...). O meu marido falava que era frescura minha, diz ele que é coisa de gente que não tem o que fazer (...), aí quando nós largamo, pouco agora, aí deu depressão nele, 'um monte de vez aí', ele falou pra mim, 'achei que era bobeira, mas não é não'(...). Domingo ele tava... eu liguei pra ele e ele falou, dai eu falei pra ele, liguei pro núcleo, eu falei pra ele 'vai lá' (...), ai toda hora eu ficava ligando pra ele. (...). Ele não gosta do meu remédio, não toma, não quer. Domingo ele falou que não queria tomar nem água, ele falou pra mim que achava que não gostava mais de mim, agora ele falou que sabe que me ama, sabe, então ele achava que não gostava mais... Essa convivência, realmente ele me ofendia demais (...), gosto também, menos, claro, isso também me afetava, então ele fazia que eu bebesse, saísse pra rua, então no outro dia eu não tava legal, tava com depressão, então foi desse jeito (...).Você sabe que depressão é coisa do diabo, é certo mesmo, quando eu tava na igreja não tinha essas coisas não, agora que eu tô desviada eu tenho, tô tentando voltar, tá difícil voltar. Eu tinha parado com tudo, não tomava cerveja, não tomava remédio, eu ia pra igreja todo domingo, era crente mesmo (,,,). Tenho mas é dificil voltar, você pensa que é fácil, o demônio impede, você não tem esse conhecimento, você pode pegar a biblia e ler, eu pego a bíblia e leio (...). Eu desviei porque ele me deu um monte de murro, apesar que nem doeu, às vezes as pessoas me perguntam, eu falo isso, não acredita, é coisa do espirito santo mesmo, não doeu os murros, sabe, é coisa de Deus, só que me abalou, falei 'eu tô na igreja', eu tô tentando levar ele, né, dai de repente ele vem e faz isso, aí eu desviei, começei a beber de novo, só pra irritar ele mesmo (...). O psiquiatra nem pergunta direito pra gente, vamos supor, a gente vai lá e ele só troca da receita, entendeu, só troca de receita, é só o remédio (...). Oh, ele (o companheiro) não acreditava de forma alguma, agora que ele acredita." 
Como já foi discutido, Isaura também mostra que os sonhos de ter seu próprio trabalho, sair da condição de doméstica para possuir uma lanchonete anexada a sua casa, ao não serem realizados, a fazem se sentir insuficiente, levando o envelhecimento a não ser acrescentado de mudança social, levando ao sentimento de derrota: "Pode ser um objetivo que eu quero alcançar e nunca consigo, sabe, como é essa lanchonete que eu fiz, aí eu não consigo terminar, não consigo o meu objetivo, dai aí você vai pondo aquilo na cabeça, vai pondo, pondo 'nossa eu preciso fazer alguma coisa', aí vai ficando doente, vai dando aquela falta de vontade de fazer as coisas.(...)."

Para as pessoas de grupos populares alcançarem as performances impostas e desejadas, fazem dos medicamentos psicoativos acessórios para seu êxito, porém quando não ocorre sucesso, um bom resultado, os mesmos medicamentos psicoativos são administrados para manipular as insatisfações, silenciando revoltas.

Portanto, a formação de habitus que define a mulher como submissa nem sempre é efetivo, precisando muitas vezes do apoio da medicina. Segundo CHALHOUB (1986), no Rio de Janeiro, século XIX, devido às mulheres serem em maior número e terem maiores facilidades de trabalho por sua relação às atividades domésticas (cozinheiras, costureiras, empregadas domésticas, lavadeiras, vendedoras de comida), isto facilita a imposição de seus desejos frente aos dos homens, negandoos: recusar submissão e se separar dos maridos indesejados, como os agressivos, infiéis. Porém, o assassinato e as agressões dos homens às mulheres não deixavam de ocorrer, revelando a impotência masculina em impor sua dominação e seu favorecimento policial ao justificarem seus crimes em defesa da honra.

A honra é aqui usada tanto para orientar o comportamento feminino como o masculino, fortalecendo o conceito de gênero e levando a mulher e o homem a se sentirem orgulhosos de realizar com eficiência seus papéis socialmente determinados (SARTI, 2003). Além disso, FONSECA (2000), em seu estudo com moradores de vilas de grupos populares nas décadas de 80 e 90, de Porto Alegre-RS, mostrou que o uso da honra como referência de sua auto-imagem organiza as relações de poder entre homem e mulher nos grupos sociais. E a humilhação sofrida pelas pessoas 
pobres nos espaços públicos (hospitais, escolas, etc) e pelos patrões levaram o trabalho autônomo a ter maior valorização e a ser visto com orgulho. Na honra está imbricada a força física tanto dos homens quanto das mulheres, usada para prevenir fofocas, acusações. Através da fofoca, humilhações em forma de piadas e acusações, as mulheres coordenam e manipulam comportamentos dos homens, promovendo sanções e demonstrando sua autonomia e seu poder com as palavras. Além disso, FONSECA (2000) descreve as traições como forma de questionar a autoridade masculina pela humilhação e a "mulher valente" que, através de atitudes, de força, da imposição de seus desejos, marca, defende e condena o que é considerado seu, incluindo o marido.

Então, o parâmetro histórico serve para contextualizar o consumo de medicamentos na atualidade, utilizados para o controle dos comportamentos, da aceitação das dificuldades financeiras e de relacionamentos intrafamiliares: controle disseminado e incorporado socialmente como um habitus. A necessidade de uso de medicamentos pode ser organizada como Isaura mostra, através da percepção das pessoas que circunvizinham os consumidores de medicamentos, fornecendo os medicamentos quando supõem que o outro precisa.

Isaura mostra que não é suficiente somente uma parte do cônjuge se enquadrar nas normas, ambas devem desempenhar comportamentos que homogeneiza dois corpos simbolicamente assimétricos. A imposição social para a ocorrência desta suposta homogeneidade manifesta a existência de coerções, pois à medida que ela não se torna possível, busca-se o culpado, ocorrendo a explicitação das hipóteses que não possibilitaram o projeto harmônico de um casal voltado para o trabalho e o consumo. O casal, ao ser visto como uma unidade em que uma parte desta coage a outra para impor comportamentos considerados normais, representando um constante julgamento e autocontrole, facilita coerções sociais. O casal internaliza um padrão a ser cumprido e se culpa quando isso não ocorre. O estar normal não é somente para si, é para o outro, é dar conta de uma relação de poder que envolve avaliação e cumprimento dos papéis sociais. As situações vivenciadas pelas mulheres entrevistadas são marcadas por relações de poder formadoras de habitus, 
determinando e exigindo comportamentos considerados aceitáveis, que ao serem transgredidos ocorre a sugestão do uso de medicamentos. A concepção do que é um estado normal da sociedade possibilita a simulação de diagnósticos. A definição dos papéis sociais relativos à mulher e ao homem através de manipulação do comportamento conduzida pela rede familiar em condição coercitiva é necessária para formar este habitus. E quando estes papéis não são cumpridos, impõe-se um caráter punitivo, sendo as transgressões vistas como patológicas e os transgressores desacreditados (BUTLER, 2003, LOURO, 2004). Pode-se dizer que a formação de um casal envolve uma falsa harmonia produzida pelas relações de poder entre homem e mulher, que é buscada com o auxílio de medicamentos psicoativos, envolvendo submissão e resistências.

Vitória (44 anos) revela os desencontros com seu marido ao descobrir que ele tinha uma amante, em um ambiente, como ela diz, que "não tinha o que colocar na panela”, e o marido a deixou com filho pequeno. O marido retornou para casa, continuaram suas vidas, com o tempo Vitória não só adquiriu experiência com o seu cotidiano, com sua vida diária cheia de insatisfações, mas também com os medicamentos psicoativos, possivelmente contribuindo para um processo de conformação, alienação, de se dizer predestinada ao seu sofrer:

"Eu não sei, eu acho que aprendi a controlar mais a ansiedade, acho que a gente vai ficando mais velha, vai aprendendo, então tem dia que eu não tomo não, tem dia que tomo só os dois à noite, tem dia que tomo só de manhã, eu tava tomando os quatro à noite, dai como eu tava ficando ruim pra dormir passei a tomar dois de manhã e dois à noite (...). Quando eu mudei pra cá eu ficava triste, não tinha vontade de nada... Às vezes nem de tomar banho,... A hora que manhecia já acordava irritada por que já amanhecia... Não queria ver gente... (...). Agora que eu aprendi a controlar mais eu fico pensando, se eu tô passando por isso, tem gente passando pior do que isto, então não adianta, o que é pra gente, é a gente mesmo que vai passar, não tem jeito."

O marido de Vitória ter tido uma amante contribuiu para que o desejo de uma realização de um ideal de casamento fosse destruído. Diferentemente de Vitória, Orlina (34 anos) me disse que por ser considerada uma pessoa muito nervosa, por já ter tentado suicídio, não sabia como o marido não havia arrumado outra mulher, mas 
que agora os filhos e o marido já sabiam quando ela estava mal e lhe davam os medicamentos.

Se considerar que o consumo de medicamentos psicoativos tem a função de controlar comportamentos, pode-se afirmar que é de também anular essas resistências à condição de gênero e classe social. O retirar a autonomia de grupos populares, não lhe permitindo resistir contra as imposições sociais, pode ser aqui notado como um dos papéis destes medicamentos, silenciando insatisfações e respostas, ora produzindo uma "felicidade" através dos antidepressivos, ora produzindo passividade através dos ansiolíticos.

PERROT (1988) diz sobre a relação entre domínio e silêncio sobre as mulheres e que a maioria dos estudos exclui as mulheres dos assuntos históricos e dos movimentos sociais, proporcionando uma visão despolitizada e não pública da mulher. E que a mulher demonstra poderes que vão desde o público ao ambiente doméstico, indo além do dualismo proposto entre a mulher maternal aceita e a diabólica recusada socialmente.

As respostas das mulheres contra uma ordem social imposta, sua procura por mudanças, é também refletida nas atitudes agressivas das mulheres. ALMEIDA (2001), em estudo realizado com mulheres presidiárias na cidade de Fortaleza no final da década de 1990, procurando analisar os assassinatos por mulheres, verificou a implementação de um projeto de conquista política, de aquisição de autonomia e liberdade. Para a autora, os crimes analisados funcionaram como forma de romper bruscamente com os mundos domésticos, inaugurando uma outra mulher que faz de seu crime meio de participar do espaço público, de revelar sua força física e contradizer o estereótipo de frágil, dócil e submissa, passando de vítima a autora, numa busca de mudanças sociais.

Não se pode rejeitar olhares críticos sobre o uso das condições de vítima e de doente nas relações de poder envolvendo gênero. Acredito que a procura dos serviços de saúde pode ser utilizada para intensificar a condição de vítima da mulher nos conflitos domésticos, o que seria intensificado pela popularização da medicina oficial, levando à maior consumo de medicamentos ansiolíticos e antidepressivos. As 
mulheres entrevistadas, em situações envolvendo agressões ou conflitos, também são medicadas, promovendo permanência da estrutura social. Como observei, as reações das mulheres contra a violência nem sempre são em um sentido de luta contra o outro que a agride, mas uma busca por mudança através do suicídio, dizendo que perdeu a cabeça frente ao descontrole. A esse respeito, para MACHADO e MAGALHÃES (1999), a "perda da cabeça" coloca a mulher, questionadora do "contrato conjugal", sob olhar clínico de doente mental, contribuindo para que somente os homens sejam vistos como certos, pois a reação frente às ações ou agressões de seus parceiros é freqüentemente vista como anormalidade. $\mathrm{O}$ uso desses medicamentos ao serem vistos como busca de controle de si provoca o controle de outrem. De acordo com MACHADO e MAGALHÃES (1999), nos contratos conjugais existe uma cláusula escondida referente à submissão das mulheres, estabelecendo que sua sexualidade fique sob domínio masculino, e fazendo as mudanças tornarem-se motivos de pesares de um passado não resolvido.

Paradoxalmente, os medicamentos ansiolíticos e antidepressivos funcionam para aliviar conflitos e divergências, dissimulando "desvios", contribuindo para que a violência simbólica seja efetivada e as mudanças sociais não ocorram.

Por um lado, as transformações sociais envolvendo gênero podem levar a conflitos conjugais quando as imagens esperadas das mulheres e dos homens não acontecem (MACHADO; MAGALHÃES, 1999), por outro lado, pode fixar determinados perfis na mulher, como a de vítima, abstendo-a de cumplicidade. Assim, surgem contextos violentos e conflituosos à medida que padrões incompatíveis com as condições socioeconômicas são exigidos. Acrescento que estes conflitos estão envoltos por mudanças psíquicas e por usos de medicamentos psicoativos em relação às mulheres, pois lhes são exigidas tanto uma imagem maternal e de trabalhadora doméstica, como de autonomia, rentabilidade financeira e beleza corporal, e em relação aos homens, exigindo que cumpra o seu papel de provedor financeiro e homem de negócios.

Não se deve homogeneizar a relação de dominação masculina no contexto brasileiro, nos grupos populares analisados por FONSECA (2000), as mulheres de 
classes populares se apresentam como mais questionadoras de sua condição frente as imposições masculinas quando comparadas com os comportamentos das mulheres de classe alta. Desse modo, a não submissão de mulheres, que colabora para o surgimento de conflitos, em grupos populares estaria favorecendo a elevação do consumo de medicamentos psicoativos.

A partir dos séculos XVII e XVIII, as mulheres e os grupos populares sofreram intervenções da união entre Estado, medicina ocidental ou oficial e valores sociais burgueses e europeus, ao procurarem controlar seus corpos (adestrando-os, disciplinando-os, docilizando-os), através de uma política que unia o biológico ao social, medicando e "normalizando" o corpo por controles de natalidade, fecundidade, morte, doença, longevidade (FOUCAULT, 1988).

Desse modo, analisei, através das concepções dadas aos medicamentos antidepressivos e ansiolíticos, como a violência colabora no consumo desses medicamentos nos grupos populares, focalizando a violência intrafamiliar e o processo de medicalização desta violência pelos serviços de saúde. De acordo com CARAVANTES (2000), o conceito de violência intrafamiliar (por exemplo, a violência conjugal, abuso sexual) é variável e depende das concepções de quem está envolvido. A violência intrafamiliar possui uma espécie de hierarquia de poder, sendo mais intensa contra as mulheres, idosos, crianças e pessoas com deficiência.

Os conflitos familiares podem se constituir por repetitivas agressões em uma relação de poder que, ao silenciar e obrigar a obedecer sem consenso, iguala-se à sua forma extrema: a violência. A violência surge quando o discurso como ação política é impossibilitado ao indivíduo, é também o último recurso do Poder aos que recusam o consenso legitimado da maioria (ARENDT, 1985). De acordo com esta autora, violência é a manifestação objetiva e clara do Poder, de obediência, mas lhe é destrutiva ao se revelar através de manifestações individuais, enquanto o Poder se apresenta como desejo de uma coletividade ou ação harmônica de um grupo. Pode-se assim supor que a violência contra a mulher, quando aceitada pela coletividade, não se apresenta como tal, funcionando como habitus, invisível, podendo chegar ao que BOURDIEU (1999) chama de violência simbólica: quando a violência passa a ser 
vista de forma naturalizada e mesmo as pessoas que a sofrem passam a requisitá-la em nome de uma norma social. Acrescento que nessas condições o Poder se mostra tão violento quanto a própria violência individualizada, o que se pode chamar de "Violência de Poder", principalmente ao se utilizar dos medicamentos psicoativos para aumentar seu limiar. Além disso, a violência, pelo lado dos atores sociais envolvidos, nem sempre é compreendida como violência, recebendo diversos significados (CARAVANTES, 2000).

Violências doméstica ou intrafamiliar, sua relação com gênero e consumo de medicamentos psicoativos, nos fazem relacionar ao papel dos serviços de saúde para contê-las. A este respeito, como MACHADO e MAGALHÃES (1999, p. 234) dizem: a violência de gênero possui tamanha especificidade entre os conflitos interpessoais que podemos chamá-la de "violência interpessoal de gênero, pois ela tem como centralidade de significados os conflitos de identidade de gênero" (grifo das autoras). Como nos alerta SCHRAIBER (2001), os serviços de saúde, restritos aos tratamentos orgânicos, ao terem dificuldade de lidar com problemas sociais ou subjetivos, não estão preparados para atenderem mulheres vítimas de violência doméstica, não conseguindo um diálogo efetivo para ajudar estas pacientes, que sofrem repetitivas agressões dos maridos e tentam por diversas vezes a procura de ajuda. E conseqüentemente, recebem diversidade de diagnósticos, sendo estereotipadas como "difíceis", “indesejáveis", "problemáticas", muitas vezes, devido à incapacidade ou frustração dos serviços de saúde em terem uma solução eficaz.

A violência envolvendo gênero se soma às dificuldades socioeconômicas vivenciadas por grupos populares. Nos bairros populares é comum imaginar, equivocadamente, uma união entre seus moradores e a não ocorrência de assaltos entre eles (FONSECA, 2000). Como mostrei, os bairros pesquisados estão envoltos também por insegurança, assaltos, às vezes dos próprios moradores ou de bairros vizinhos, sendo os medicamentos psicoativos como justificativa tanto dos conflitos gerados pelos assaltos e pela violência como ocorreu na chamada "guerra das favelas". Nesse sentido, as próprias coerções para implantação de um modelo de 
comportamento, ao afirmar discriminações, podem colaborar para que a violência ocorrida nos lares dos grupos populares seja dissimulada, fazendo assim destacar a importância do encontro dialógico entre serviços de saúde e grupos populares.

Para SCHRAIBER (2001), a própria indefinição do conceito de violência leva os profissionais de saúde a vê-la como natural, não evitando que ocorram transtornos mentais devido a prolongados conflitos entre membros das famílias. Segundo a autora, tanto para pacientes quanto para os profissionais de saúde, a violência doméstica, por ocorrer no espaço privado, muitas vezes não é considerada violência em si, e por isso é tratada como problema individual e não social. Conseqüentemente, SCHRAIBER e OLIVEIRA (1999) e SCHRAIBER (2001) propõem que a busca de solução para a mulher vivendo em situação de violência doméstica deve fazer parte de uma relação envolvendo serviços de saúde e vários setores, como Segurança Pública, Justiça, Assistência Social, prestando uma assistência a estas pacientes de maneira compartilhada, vendo-as como sujeito de direitos, capazes de avaliar e optar por decisões e caminhos. Esta assistência interdisciplinar e intersetorial às pessoas em situação de violência deve ser valorizada e construída com cautela e ética, não posicionando a mulher como culpada.

Os serviços de saúde devem estar sempre atentos às relações de poder envolvendo a mulher. Ao mesmo tempo, vitimizá-las levaria a analisá-las com nuances de preconceito, reafirmando fragilidade, falta de autonomia nas situações envolvendo violência. É bom lembrar que a busca de solução da violência doméstica por parte das mulheres não é fato incomum, no entanto, é dificultada por falta de apoio da família, má condição econômica, medo, culpa, amor, idéia de que violência faz parte apenas de seu mundo privado, de que já é naturalizada e de que não tem jeito, por manipulação do agressor e dificuldade de acesso a serviços de saúde (SCHRAIBER, 2001). Como diz MACHADO e MAGALHÃES (1999), em relação à violência conjugal, não basta entender as mulheres somente como vítimas, é preciso compreender suas reações, interações e como a violência é construída na vida conjugal. A violência conjugal, além das relações de poder, possui também aspectos subjetivos como afetividade, sexualidade, amor, paixão, ódio, vingança, desejos e 
vontades. Mas não se pode restringir a uma relação subjetiva envolvendo somente os cônjuges, estes conflitos estão também moldados pelas relações envolvendo toda a família.

\section{CONSIDERAÇÕES FINAIS}

Os estudos sobre medicamentos prescritos geralmente se reduzem ao biológico e sua relação com o meio social é esquecida. No entanto, os medicamentos estão também inseridos em uma problemática que deve ser contextualizada, abarcando diferentes interpretações sobre seus efeitos, envolvendo classe social, sexo, gênero, idade, curso de vida e história social da doença e do medicamento.

Estudar o consumo de medicamentos a partir da realidade de seus consumidores é formular contribuições para uma relação dialógica entre serviços de saúde e população. Nesse sentido, o cotidiano colabora na construção do consumo de medicamentos. Os medicamentos psicoativos estão assim organizados através desse cotidiano, e não necessariamente pela exclusiva relação serviços de saúde/população usuária.

Ao fazer o percurso que vai desde a dispensação dos medicamentos até o seu consumo, pude observar que o medicamento adquire diferentes significados e usos. O caminho que os medicamentos percorrem é particularizado pelas questões socioculturais envolvendo seus efeitos farmacológicos. Os serviços de saúde, ao prescreverem e distribuírem os medicamentos, são produtores de concepções sobre os medicamentos não somente pela mensagem relacionada aos mesmos, mas pelo modo que se efetiva uma comunicação entre serviço e população.

Os medicamentos antidepressivos e ansiolíticos foram compreendidos como elo entre pesquisador e pesquisados, o encontro de diferentes cursos de vida, de 
diferentes histórias. Estes medicamentos psicoativos foram aqui observados através do cotidiano de seus consumidores, interligando resistência e poder, entre alegrias e decepções, entre desejos e frustrações.

Os medicamentos psicoativos, ao serem concebidos como medicamentos para conflitos, incluíram também os conflitos existentes entre serviços de saúde e população. Os conflitos se mostraram emblemáticos tanto pela localização das residências nos bairros investigados como pelos atritos envolvendo os diferentes bairros. Desse modo, pode-se interrogar quais as relações entre local de moradia e o consumo de medicamentos psicoativos, assim como o tipo de moradia e as posições simbólicas nas relações de gênero e classe social em cursos de vida individualizados.

O curso de vida está marcado por desgastes físicos e emocionais, seja pela morte de entes queridos, pelo sofrimento com doenças de familiares, pelas dificuldades econômicas, entre outras. A família, como trajetória sócio-histórica, é muito exaltada no curso de vida como causadora do consumo de medicamentos psicoativos, como disse uma senhora na rua: "família é o demônio, meu sangue é venenoso, o que está no meu sangue é só desgraça, a família faz doença na cabeça”.

Caminhar pelos diferentes bairros me possibilitou analisar os conflitos das diferenças e desigualdades sociais, levando-me a presenciar/participar de conflitos e suas relações com justificativas para o consumo de medicamentos psicoativos, revelando o quão distante os serviços de saúde estão de um lógica baseada na promoção da saúde. Os serviços de saúde de atenção básica, como o Núcleo de Saúde da Família, mostraram-se como uma etapa do modelo curativo vigente, não se destacando com autonomia para colaborar na produção de saúde.

O trabalho doméstico realizado pelas mulheres entrevistadas se mostrou relacionado com o uso de medicamentos psicoativos ao dizerem que estes as auxiliavam nestes afazeres ao proporcionarem uma disciplina e extensão dos limites do corpo, na anulação de conflitos entre os membros de suas famílias, ajudando a conservar uma estrutura social de domínio relacionado ao sexo masculino e de subalternidade dos grupos populares. O dia-a-dia marcado pelo excesso de trabalho e o modo de sua execução são ditos como uma problemática relacionada ao consumo 
de medicamentos psicoativos. O trabalho realizado no espaço doméstico pelas donasde-casa soma-se aos outros trabalhos, como os realizados em outras casas e o de reciclagem de materiais como garrafas, latas de bebidas e papelão. O homem, buscando reafirmar sua masculinidade, procura por maiores ganhos por meio de uma extensão de sua "força de trabalho", através de seu próprio corpo ou através do domínio do trabalho de suas companheiras.

As diferenças analisadas nos bairros favoreceram também análises de diferentes modos e justificativas de uso dos medicamentos psicoativos. Ansiolíticos e antidepressivos revelaram usos desiguais, concentrando-se os entrevistados no consumo de antidepressivos, considerando o consumo de ansiolíticos como para situações eventuais e consideradas mais graves. Estas concepções podem estar sendo favorecidas por um trivializar do consumo de antidepressivos pelos serviços de saúde. Os ansiolíticos passam a ser enfatizados como para um problema de saúde voltado para a psiquiatria, deixando os entrevistados de usá-los ou apenas os consumindo nos momentos considerados mais problemáticos.

A experiência com o uso dos medicamentos não se resumem aos efeitos dos mesmos, ocorre a ampliação para os eventos acontecidos no curso de vida dos entrevistados, a memória se torna presente. O sentido de lugar geográfico e social teve uma representação significativa sobre o consumo dos medicamentos, ora justificado por um percurso de sofrimento relacionado às dificuldades socioeconômicas, ora pelo medo entre/pelos moradores, ora pelos deslocamentos de posições consideradas socialmente definidas. Assim, o curso de vida do consumidor se confronta com o que se considera um outro desconhecido, devendo este passar por aprovações, orientadas por relações de poder, levando ao silêncio de conflitos, dissimulando olhares e preconceitos marcados anteriormente por discriminações explicitas e faladas, pré-dizendo posições consideradas ideais de mulheres, homens, pobres, ricos. O outro, quando visto como incômodo, é sentido pelo corpo através de sintomas de depressão e ansiedade, que ao serem medicalizados, são silenciados, esquecidos, levando os conflitos entre os moradores dos bairros a possuírem uma nova configuração, sentido de afastamento, de insignificância sobre o outro. 
Os conflitos sociais e de gênero devem ser questionados por perspectivas que produzam diálogos, evitando a sua medicalização. Do mesmo modo, as diferenças socioculturais, ao produzirem um processo de distinção, podem levar ao surgimento de preconceitos e conseqüentemente ao uso de medicamentos psicoativos tanto no sentir como no ter preconceitos, devido aos conflitos inerentes. Assim, pude observar a justificativa do uso dos medicamentos devido a esse outro que incomoda e traz o medo de se tornar um dele, medo de "passar para o outro lado da rua". Os bairros foram diferenciados pelos entrevistados de acordo com o estilo de vida e o tipo de moradia, estes simbolizando a favela como lugar de atraso científico e econômico, sendo representada como perigo devido a seus moradores serem considerados não seguidores dos preceitos dos serviços de saúde e por não terem o mesmo êxito de outros grupos sociais, provocando o consumo de medicamentos psicoativos.

Os entrevistados da parte antiga do bairro e da parte de casas COHAB, na busca por melhores condições de saúde e para um êxito econômico, passam a utilizar os medicamentos psicoativos como seus auxiliares. A distinção é ao mesmo tempo provocadora e justificadora do consumo de medicamentos psicoativos. Assim, os atos considerados erros foram sempre exaltados para proclamar a diferença, a distinção com o outro considerado "um favelado pobre", lugar em que "lá tem tráfico", "lá tem prostituição", "são uns vagabundos", "uma bebedeira", "não são daqui", "vem lá do fim do mundo", o que se contrasta com "eu sou um trabalhador", “aqui tomo mundo é gente boa", "lá também tem gente boa, é gente como a gente". E por outro lado, como disse um vigilante noturno do bairro das casas luxuosas: "olha, aqui que tem tráfico, um dia uma daquelas casas tava cheia de traficante, a polícia foi lá".

As divisões espaciais esclarecem diferentes perspectivas, fazendo um bairro ganhar novas divisões de acordo com os moradores e transeuntes. Não uma simples demarcação imposta pela administração pública, mas as definições como as conotações dadas pela população relativas à classe, às relações de gênero e aos lugares em que viveram anteriormente como zona rural, outros Estados, levando a serem identificados pelo tipo de moradia, modos de se vestirem, de comerem, etc. 
Os afazeres do dia-a-dia surgidos no ambiente doméstico se impõem através das relações de gênero que estão em comunicação com a estrutura social. O encontro do privado com o público faz do trabalho doméstico elucidativo de conflitos criados pelo debate entre as pessoas que compõem o lar, problematizando a estática de representações de conceito de gênero e espelhando a dinâmica social.

$\mathrm{O}$ uso de medicamentos psicoativos é requerido para padronizar um comportamento aceito, o corpo dócil e disciplinado, suficiente para as exigências sociais ilimitadas. A medicalização se amplia tanto para mulheres como para homens na produção deste corpo considerado ideal. Assim, os medicamentos psicoativos são utilizados para sustentar um conceito de gênero baseado na diferença estática entre homens e mulheres.

Olhar os consumidores de medicamentos ansiolíticos e antidepressivos como “portadores" de sintomas compatíveis com a utilização destes medicamentos não é suficiente, pois poderia estar medicalizando suas atitudes frente ao sofrimento social imposto a elas, provocando um benefício orgânico às avessas, fazendo o corpo suportar ainda mais dor e sofrimento. O fornecimento de prescrições de medicamentos pelos serviços de saúde deve ser reflexivo ao contexto social em que os atores estão envolvidos.

Como existe uma projeção de se impor o modelo de modo de vida das classes mais abastadas aos grupos populares, apoiadas pelas tecnologias, pelos meios de comunicação de massa, pregando uma sociedade em que cada corpo é responsabilizado por seu próprio desenvolvimento, em uma condição individualista, autônoma e consumista, pode estar correndo o risco de medicalizar os grupos populares ao invés de promover ações políticas com alteridade que diminuam as desigualdades sociais. Portanto, os grupos populares, ao serem impostos a uma condição de afastamento social, estariam mais susceptíveis ao consumo de medicamentos psicoativos, pois se revelam em uma situação limiar, envolvendo mudanças sociais em que se une o dar conta do espaço público (autonomia e individualismo) e do privado (relações familiares). 
O consumo de medicamentos antidepressivos e ansiolíticos deve ser analisado com cautela pelos serviços de saúde, pois seu uso indevido, não analisando questões sociais, pode estar contribuindo também para a perpetuação de situações de violência intrafamiliar. Assim, programas de saúde que integrem interdisciplinarmente serviços de saúde, subjetividade e questões sociais podem proporcionar caminhos que contribuam para a diminuição da violência na sociedade e do uso indevido de medicamentos.

O consumo de medicamentos perpassa pela relação entre os diversos profissionais de saúde e a população usuária, muitas vezes as informações são desencontradas, confrontando a prescrição médica com a dispensação. Portanto, a relação do serviço de saúde com a população pode ser estendida através de ações dialógicas entre Estratégia de Saúde da Família e a dispensação de medicamentos pela farmácia. Nesse sentido, estes profissionais devem estar preparados para colaborar no uso dos medicamentos de forma que não promovam malefícios à saúde da população.

Os medicamentos nem sempre têm uma atenção devida por parte dos profissionais, como pelos agentes comunitários de saúde, que ao estabelecerem também uma relação de poder com a população, ampliam um saber-poder que não condiz com a literatura científica sobre os medicamentos prescritos. NUNES e col. (2008) observaram que os agentes comunitários de saúde (pesquisa realizada em uma Unidade Básica de Saúde da cidade de Porto Alegre-RS) sentiam necessidade de melhores informações sobre os medicamentos por não se considerarem preparados para contribuírem com o seu melhor uso, destacando o medicamento como função preventiva e o seu desperdício.

Como observei, muitos medicamentos psicoativos foram adquiridos na farmácia e não foram consumidos ou foram emprestados ou doados para familiares ou pessoas conhecidas. Uma melhor proximidade dos agentes comunitários de saúde com a população e uma comunicação com a farmácia pode colaborar para que se evitem desperdícios de medicamentos, levando à economia de gastos públicos com medicamentos. 
Assim, sugiro que se tenha um melhor diálogo ou interação entre o Núcleo de Saúde da Família, farmácia e prescritores de medicamentos. Estas três esferas devem promover a aproximação com o paciente e não o desenvolvimento de imposições autoritárias dos serviços de saúde que distanciam a compreensão dos medicamentos fora dos parâmetros científicos. A ciência deve assim colaborar para um diálogo e não para uma imposição autoritária. O medicamento deve ser elo de ligação e diálogo, evitando que a população distancie da ciência, não uma ciência autoritária que se impõe, mas uma ciência dialógica que respeita opiniões divergentes e que produz educação em saúde e promova melhores condições de vida, facilitando que os problemas sociais sejam questionados, não favorecendo a sua dissimulação através dos efeitos farmacológicos dos medicamentos.

Através da Estratégia de Saúde da Família pode se ampliar um diálogo com a população sobre o consumo de medicamentos, analisando os modos de uso prescritos pelos serviços e também seus variáveis modos aplicados pela população com os efeitos indesejados dos medicamentos e o desenvolvimento de autocríticas dos serviços de saúde, colaborando para rever os procedimentos e formando um diálogo circular entre serviços e população. Acredito que a preparação do profissional farmacêutico para a inserção na Estratégia de Saúde da Família pode colaborar para a problematização do consumo de medicamentos, colaborando para que a ciência faça parte de um encontro e não de desencontros e confrontos. 


\section{REFERÊNCIAS}

ADORNO, Rubens de Camargo Ferreira. Sociologia: um ensaio de introdução ao seu campo e a algumas de suas vertentes. In: BOTAZZO, Carlos; FREITAS, Sérgio Fernando Torres de (Org.). Ciências sociais e saúde bucal: questões e perspectivas. Bauru, SP: EDUSC/ São Paulo: Fundação Editora da UNESP, 1998. p. 105-126.

ADORNO, Rubens de Camargo Ferreira. A cidade como construção moderna: um ensaio a respeito de sua relação com a saúde a as "qualidades de vida". Saúde e Sociedade, São Paulo, v. 8, n. 1, p.17-30, jan./mar. 1999.

ADORNO, Rubens de Camargo Ferreira; CASTRO, Ana Lúcia de. O exercício da sensibilidade: pesquisa qualitativa e a saúde como qualidade. Saúde e Sociedade, São Paulo, v. 3, n. 2, p.172-185, maio/ago. 1994.

AGUIAR, Adriano Amaral de. A psiquiatria no divã: entre as ciências da vida e a medicalização da existência. Rio de Janeiro: Relume Dumará, 2004.

ALMEIDA, Rosemary de Oliveira. Mulheres que matam: universo imaginário do crime no feminino. Rio de Janeiro: Relume Dumará/UFRJ, 2001.

ALMEIDA, Miguel Vale. Gênero, masculinidade e poder. Revendo um caso do Sul de Portugal. In: ALMEIDA, Miguel Vale. Outros destinos: ensaios de antropologia e cidadania. Porto: Campo das Letras, 2004. p. 155-182.

ALVES, Paulo César B.; SOUZA, Iara Maria A. Escolha e Avaliação de Tratamento para Problemas de Saúde: considerações sobre o itinerário terapêutico. In: RABELO, Míriam Cristina M.; ALVES, Paulo César B.; SOUZA, Iara Maria A. Experiência de Doença e Narrativa. Rio de Janeiro: Editora Fiocruz, 1999. p. 125-138.

ANDRADE, Rosane. Fotografia e antropologia: olhares fora-dentro. São Paulo: Estação Liberdade/EDUC, 2002.

ANDRADE, Laura Helena S. G. de; VIANA, Maria Carmen; SILVEIRA, Camila Magalhães. Epidemiologia dos transtornos psiquiátricos na mulher. Revista de Psiquiatria Clínica, São Paulo, v. 33, n. 2, p. 43-54, 2006. 
ARAÙJO, Clara; SCALON, Celi. Gênero e a distância entre a intenção e o gesto. Revista Brasileira de Ciências Sociais, São Paulo, v. 21, n. 62, p.45-68, out. 2006.

ARENDT, Hannah. Da violência. Tradução de M. C. D. Trindade. Brasília: Editora Universidade de Brasília, 1985.

ATKINSON, Paul; HAMMERSLEY, Martyn. Ethnography and participant observation. In: DENZIN, Norman K.; LINCOLN, Yvonna (Org.). Handbook of qualitative research. New Delhi: Sage Publications, 1994. p.248-261.

AVENEL, Cyprien. A família ambígua. O caso dos moradores dos subúrbios populares de Bordeaux. Tradução de A. X. de Brito. In: PEIXOTO, Clarice Ehlers; SINGLY, François de; CICCHELLI, Vincenzo (Org.). Família e individualização. Rio de Janeiro: FGV, 2000. p. 33-48.

AUGÉ, Marc. Não-lugares: introdução a uma antropoloiga da supermodernidade. Tradução de M. L. Pereira. Campinas: 1994.

AZIZE, Rogerio Lopes. Uma neuro-weltanschanuung? Fisicalismo e subjetividade na divulgação de doenças e medicamentos do cérebro. Mana: Estudos de Antropologia Social, Rio de Janeiro, v. 14, n. 1, p. 7-30, 2008.

BACHELARD, Gaston. A formação do espírito científico: contribuição para uma psicanálise do conhecimento. Tradução de E. S. Abreu. Rio de Janeiro: Contraponto, 1996.

BARETA, Gracce Maria Scott. Atenção Farmacêutica em Farmácias Comunitárias. In: RASIA, José Miguel; GIORDANI, Rubia C. Formighieri (Org.). Olhares e questões sobre a saúde, a doença e a morte. Curitiba: Ed. UFPR, 2007. p. 41-71.

BARROS, José Augusto C. Estratégia mercadológica da indústria farmacêutica e o consumo de medicamentos. Revista de Saúde Pública, São Paulo, v.14, n. 5, p. 377 386, out. 1983.

BASSIT, Ana Zahira. O curso de vida como perspectiva de análise do envelhecimento. In: DEBERT, Guita Grin; GOLDSTEIN, Donna M. (Org.). Políticas do corpo e o curso da vida. São Paulo: Sumaré, 2000. p.217-234.

BERMAN, Marshall. O Fausto de Goethe: A tragédia do Desenvolvimento. In: BERMAN, Marshall. Tudo que é sólido desmancha no ar: aventura da modernidade. Tradução de C. F. Moisés e A. M. L. Ioriatti. São Paulo: Companhia das Letras, 1986. p. 37-84.

BITTENCOURT, Luciana Aguiar. Algumas considerações sobre o uso da imagem fotográfica na pesquisa antropológica. In: FELDMAN-BIANCO, Bela; LEITE, 
Míriam L. Moreira. Desafios da imagem: fotografia, iconografia e vídeo nas ciências sociais. Campinas: Papirus Editora, 1998. p. 197-212.

BOLTANSKI, Luc. As Classes sociais e o corpo. Tradução de R. A. Machado. 3. ed. Rio de Janeiro: Graal, 1984.

BOURDIEU, Pierre. A ilusão biográfica. In: BOURDIEU, Pierre. Razões práticas: sobre a teoria da ação. Tradução de Mariza Corrêa. Campinas: Papirus, 1996. p. 7482 .

BOURDIEU, Pierre. Campo do poder, campo intelectual e Habitus de Classe. In: BOURDIEU, Pierre. A economia das trocas simbólicas. São Paulo: Perspectiva, 1998. p. 183-202.

BOURDIEU, Pierre. A dominação masculina. Tradução de M. H. Kühner. Rio de Janeiro: Bertrand Brasil, 1999.

BOURDIEU, Pierre. A Distinção: crítica social do julgamento. Tradução de D. Kern e G. J. F. Teixeira. São Paulo: Edusp/ Porto Alegre: Zouk, 2007.

BRANT, Luiz Carlos; MINAYO-GOMEZ, Carlos. Da tristeza à depressão: a transformação de um mal-estar em adoecimento no trabalho. Interface Comunicação, Saúde, Educação, v.12, n.26, p. 667-676, jul./set. 2008.

BRASIL. Lei $\mathrm{n}^{\mathrm{o}}$ 5.991, de 17 de dezembro de 1973. Dispõe sobre o controle sanitário do comércio de drogas, medicamentos, insumos farmacêuticos e correlatos, e dá outras providências. Diário Oficial da União, Brasília, DF, 19 dez. 1973.

BRASIL. Lei n. ${ }^{\circ}$ 9787, de 10 de fevereiro de 1999. Altera a lei n. ${ }^{\circ} 6360$, de 23 de setembro de 1976, que dispõe sobre a vigilância sanitária, estabelece o medicamento genérico, dispõe sobre a utilização de nomes genéricos em produtos farmacêuticos e dá outras providências. Diário Oficial da República Federativa do Brasil, Brasília, DF, 11 fev. 1999. Seção 1, 4 p.

BRASIL. Ministério da Saúde. Secretaria de Políticas de Saúde. Departamento de Atenção Básica. Política nacional de medicamentos. Brasília: Ministério da Saúde, 2001 .

BRASIL. Ministério da Saúde. Secretaria de Ciência, Tecnologia e Insumos Estratégicos. Departamento de Assistência Farmacêutica e Insumos Estratégicos. Assistência Farmacêutica na Atenção Básica: instruções técnicas para sua organização. 2. ed. Brasília: Ministério da Saúde, 2006. 
BRASIL. Resolução RDC no 39, de 05 de junho de 2008. Aprova o Regulamento para a realização de pesquisa clínica e dá outras providências. Diário Oficial da União, Brasília, DF, 06 jun. 2008.

BRIOSCHI, Lucila Reis; TRIGO, Maria Helena Bueno. Relatos de vida em ciências sociais: considerações metodológicas. Ciência e Cultura, São Paulo, v.39, n.7, p.631-637, jul. 1987.

BRUSCHINI, Cristina. Trabalho doméstico: inatividade econômica ou trabalho nãoremunerado? Revista Brasileira de Estudos de População, São Paulo, v. 23, n. 2, p. 331-353, jul./dez. 2006.

BRUSCHINI, Cristina. Trabalho e Gênero no Brasil nos últimos dez anos. Cadernos de Pesquisa, São Paulo, v.37, n.132, p.538-572, set/dez, 2007.

BUTLER, Judith. P. Problemas de gênero: feminismo e subversão da identidade. Tradução de R. Aguiar. Rio de Janeiro: Civilização Brasileira, 2003.

CACCIA-BAVA, Maria do Carmo G.G. Relatório do Convênio Núcleos de Saúde da Família Centro de Saúde Escola da Faculdade de Medicina de Ribeirão Preto Universidade de São Paulo. Ribeirão Preto, 2004.

CALIL JÚNIOR, Ozório. O centro de Ribeirão Preto: os processos de expansão e setorização. 2003. 209 p. Dissertação (Mestrado) - Escola de Engenharia de São Carlos, Universidade de São Paulo, São Paulo.

CANGUILHEM, Georges. Escritos sobre a medicina. Tradução de V. A. Ribeiro. Rio de Janeiro: Forense Universitária, 2005.

CARAVANTES, Lily. Violencia intra-familiar en la reforma del sector salud de Centroamérica. In: COSTA, Ana Maria; MERCHÁN-HAMANN, Edgar; TAJER, Débora (Org.). Saúde, equidade e gênero: um desafio para as políticas públicas. Brasília: Editora UnB, 2000. p. 227-239.

CAROSO, Carlos. A imagem e a ética na encruzilhada das ciências. In: VÍCTORA, Ceres et al. (Org.). Antropologia e Ética: o debate atual no Brasil. Niterói: EDUFF/ABA, 2004. p. 137-150.

CARVALHO, Isalena Santos; COELHO, Vera Lúcia Decnop. Mulheres na maturidade: histórias de vida e queixa depressiva. Estudos de Psicologia, Natal, v. 10, n. 2, p. 231-238, maio/ago. 2005.

CERTEAU, Michel de. A invenção do Cotidiano: 1. Artes de fazer. Tradução de E. F. Alves. 11. ed. Petrópolis: Vozes, 2005. 
CHALHOUB, Sidney. Trabalho, bar e botequim: O cotidiano dos trabalhadores no Rio de Janeiro da belle époque. São Paulo: Brasiliense, 1986.

CHALHOUB, Sidney. Cidade febril: cortiços e epidemias na Corte imperial. São Paulo: Companhia das Letras, 1996.

CLASTRES, Pierre. A sociedade contra o Estado: pesquisas de antropologia política. São Paulo: Cosac \& Naify, 2003.

COHN, Amélia. O estudo das políticas de saúde: implicações e fatos. In: CAMPOS, Gastão Wagner de Souza, et al. (Org.). Tratado de Saúde Coletiva. São Paulo: Hucitec/Rio de Janeiro: Editora Fiocruz, 2006. p.231-258.

COMTE-SPONVILlE, André. A felicidade, desesperadamente. Tradução de E. Brandão. São Paulo: Martins Fontes, 2001.

CONRAD, Peter. The Medicalization of Society: on the transformation of human conditions into treatable disorders. Baltimore: The Johns Hopkins University Press, 2007.

CZERESNIA, Dina; RIBEIRO, Adriana Maria. O Conceito de Espaço em Epidemiologia: uma interpretação histórica e epistemológica. Cadernos de Saúde Pública, Rio de Janeiro, v. 16, n. 3, p. 671-693, jul./set. 2000.

DAMATTA, Roberto. A casa \& a rua : espaço, cidadania, mulher e morte no Brasil. 6. ed. Rio de Janeiro: Rocco, 1997.

DEBERT, Guita. Grin. Gênero e envelhecimento. Estudos Feministas, Rio de Janeiro, v. 2, n. 1, p. 33-51, $1^{\circ}$ sem., 1994.

DIEHL, Eliana; RECH, Norberto. Subsídios para uma assistência farmacêutica no contexto da atenção à saúde indígena: contribuições da antropologia. In: LANGDON, Ester Jean; GARNELO, Luiza (Org.). Saúde dos povos indígenas: reflexões sobre antropologia participativa. Rio de Janeiro: Contra Capa Livraria/Associação Brasileira de Antropologia (ABA), 2004, p. 149-169.

DIWAN, Pietra. Raça pura: uma história da eugenia no Brasil e no mundo. São Paulo: Contexto, 2007.

DUARTE, Luiz Fernando Dias. Da vida nervosa nas classes trabalhadoras urbanas. Rio de Janeiro: Jorge Zahar/ Brasília: CNPq, 1986.

DUPUY, Jean-Pierre; KARSENTY, Serge. A invasão farmacêutica. Tradução de C. R. Oliveira. Rio de Janeiro: Edições Graal, 1979. 
DURHAM, Eunice Ribeiro. A família operária: consciência e ideologia. In: DURHAM, Eunice Ribeiro. A dinâmica cultural: ensaios de antropologia. São Paulo: Cosac Naify, 2004. p. 237-253.

EHRENBERG, Alain. L’individu incertain. Paris: Calmann-Lévy, 1995.

ELIAS, Denise. Globalização e Agricultura: a região de Ribeirão Preto - SP. São Paulo: Edusp, 2003.

ELIAS, Norbert; SCOTSON, John L. Os Estabelecidos e os Outsiders: sociologia das relações de poder a partir de uma pequena comunidade. Tradução de V. Ribeiro. Rio de Janeiro: Jorge Zahar Ed., 2000.

ENGEL, Magali. Psiquiatria e feminilidade. In: PRIORE, Mary Del (Org.); BASSANEZI, Carla (Coord.). História das mulheres no Brasil. 7. ed. São Paulo: Contexto/Unesp, 2004. p.322-361.

FAINZANG, Sylvie. Les médicaments dans l'espace privé: festion individuelle ou collective. Anthropologie et sociétés, Québec, v. 27, n.2, p. 139-154, sept. 2003.

FEATHERTONE, Mike; HEPWORTH, Mike. Envelhecimento, tecnologia e o curso da vida incorporado. In: DEBERT, Guita Grin; GOLDSTEIN, Donna M. (Org.). Políticas do corpo e o curso da vida. São Paulo: Sumaré, 2000. p.109-132.

FERREIRA, Jaqueline. Cuidados do corpo em vilas de classes populares. In: DUARTE, Luiz Fernando Dias; LEAL, Ondina Fachel (Org.). Doença, sofrimento, perturbação: perspectivas etnográficas. Rio de Janeiro: Fiocruz, 1998. p. 49-56.

FONSECA, Claudia. Família, fofoca e honra: etnografia de relações de gênero e violência em grupos populares. Porto Alegre: Editora Universidade/UFRGS, 2000.

FONSECA, Claudia. Concepções de família e práticas de intervenção: uma contribuição antropológica. Saúde e Sociedade, São Paulo, v. 14, n. 2, p. 50-59, maio-ago., 2005.

FOUCAULT, Michel. Microfísica do poder. 4. ed. Rio de Janeiro: Graal, 1984.

FOUCAULT, Michel. O Nascimento da clínica. Tradução de R. Machado. 3. ed. Rio de Janeiro: Forense-Universitária, 1987.

FOUCAULT, Michel. História da sexualidade I: a vontade de saber. São Paulo: Editora Graal, 1988. 
GEERTZ, Clifford. Uma descrição densa: teoria interpretativa da Cultura. In: GEERTZ, Clifford. A interpretação das culturas. Rio de Janeiro: editora LTC, 1989. p. 3-21.

GIOVANNI, Geraldo. A questão dos remédios no Brasil: produção e consumo. São Paulo: Livraria e Editora Polis, 1980.

GOFFMAN, Erving. Estigma: notas sobre a manipulação da identidade deteriorada. Tradução de M. B. M. L. Nunes. Rio de Janeiro: LTC, 1988.

GOMES, Romeu. Sexualidade masculina, genero e saúde. Rio de Janeiro: Fiocruz, 2008 .

GROULX, Lionel-Henri. Contribuição da pesquisa qualitativa à pesquisa social. In: POUPART, Jean, et al. A pesquisa qualitativa: enfoques epistemológicos e metodológicos. Tradução de A. C. Nasser. Petrópolis: Vozes, 2008. p. 95-124.

HELMAN, Cecil G. Cultura, saúde e doença. Tradução de E. Mussmich. 2. ed. Porto alegre: Artes Médicas, 1994.

HOCHMAN, Gilberto. A era do saneamento: as bases da política de Saúde Pública no Brasil. São Paulo: Hucitec, 1998.

HOLANDA, Sérgio Buarque de. Raízes do Brasil. $3^{\text {a }}$ ed. São Paulo: Companhia das Letras, 1997.

HOUAISS, Antonio. Dicionário eletrônico Houaiss da língua portuguesa. $2^{\mathrm{a}}$ ed. Rio de Janeiro: Objetiva, 2007.

ILLICH, Ivan. A expropriação da saúde: nêmesis da medicina. 4 ed. Tradução de J. K. Cavalcanti. Rio de Janeiro: Editora Nova Fronteira, 1975.

KLEINMAN, Arthur. The meaning of symptoms and disorders. In: KLEINMAN, Arthur. The illness narratives: suffering, healing, and the human condition. New York: BasicBooks, 1988. p. 3-30.

KOFES, Suely. Mulher, mulheres: identidade, diferença e desigualdade na relação entre patroas e empregadas domésticas. Campinas: Ed. Unicamp, 2001.

LANGDON, Esther Jean. A doença como experiência: a construção da doença e seu desafio para a prática médica. Florianópolis: UFSC, 1996. p.1-8. Disponível em: $<$ http://www.cfh.ufsc.br/ nessi/A\%20Doenca\%20como\%20Experiencia.htm $>$. Acesso em: 12 jul. 2005. 
LAPLANTINE, François. Antropologia da doença. Tradução de V. L. Siqueira. 3. ed. São Paulo: Martins fontes, 2004.

LEITE, Silvana Nair; VASCONCELLOS, Maria da Penha. Adesão à terapêutica medicamentosa: elementos para a discussão de conceitos e pressupostos adotados na literatura. Ciência \& Saúde Coletiva, Rio de Janeiro, v. 8, n. 3, p. 775-782, 2003.

LOURO, Guacira Lopes. Um corpo estranho: ensaios sobre sexualidade e teoria queer. Belo Horizonte: Autêntica, 2004.

LOYOLA, Andréa Maria. Médicos e Curandeiros: conflito social e saúde. São Paulo: DIFEL, 1984.

LUDERMIR, Ana Bernarda. Desigualdades de classe e gênero e saúde mental nas cidades. Physis: Revista de Saúde Coletiva, Rio de Janeiro, v. 18, n. 3, p. 451-467, set. 2008.

LUZ, Madel Therezinha. Natural, racional, social: razão médica e racionalidade científica moderno. 2. ed. São Paulo: Hucitec, 2004.

MACHADO, Maria Helena (Coord.). Os médicos no Brasil: um retrato da realidade. Rio de Janeiro: Fiocruz, 1997.

MACHADO, Lia Zanotta; MAGALHÃES, Maria Tereza Bossi de. Violência conjugal: os espelhos e as marcas. In: SUÁREZ, Mireya; BANDEIRA, Lourdes (Org.). Violência, gênero e crime no Distrito Federal. Brasília: Editora UnB, 1999. p. 173-237.

MAGNANI, José Guilherme Cantor. A rua e a evolução da sociabilidade. Cadernos de História de São Paulo, São Paulo, n. 2, p. 45-54, jan.-dez. 1993.

MAGNANI, José Guilherme Cantor. De perto e de dentro: notas para uma etnografia urbana. Revista Brasileira de Ciências Sociais, São Paulo, v. 17, n. 49, p. 11-29, jun. 2002.

MALPASS, Alice, et al. "Medication career" or "Moral career"? The two sides of managing antidepressants: a meta-ethnography of patients' experience of antidepressants. Social Science \& Medicine, v. 68, p. 154-168, 2009.

MARQUESE, Rafael de Bivar. Feitores do corpo, missionários da mente: Senhores, letrados e o controle dos escravos nas Américas, 1660-1860. São Paulo: Companhia das Letras, 2004.

MARTINS, José de Souza. Capitalismo e tradicionalismo. São Paulo: Livraria Pioneira Editora, 1975. v. 1. 
MARTINS, José de Souza. Fronteira: a degradação do Outro nos confins do humano. São Paulo: Hucitec, 1997.

MELO, Hildete Pereira; CONSIDERA, Claudio Monteiro; SABBATTO, Alberto Di. Os afazeres domésticos contam. Economia e Sociedade, Campinas, v. 16. n.3, p. 435-454, dez. 2007.

MENDONÇA, Reginaldo Teixeira. Representações de mulheres idosas usuárias de um serviço de saúde: relações entre consumo de calmantes, gênero e envelhecimento. 2005. 174 p. Dissertação (Mestrado em Saúde na Comunidade) Departamento de Medicina Social, Faculdade de Medicina de Ribeirão Preto, Universidade de São Paulo, Ribeirão Preto.

MIZUTANI, Augusto Takachi. Cafeicultores de Ribeirão Preto: 1904 a 1935. 2002. 72 p. Monografia (Graduação) - Departamento de Economia, Faculdade de Economia, Administração e Contabilidade, Universidade de São Paulo, Ribeirão Preto.

MORIN, Edgar. A Felicidade. In: MORIN, Edgar. Cultura de massas no século vinte (o espírito do tempo). Tradução de Maura Ribeiro Sardinha. Rio de Janeiro: Forense, 1967, p. 131-136.

MORIN, Edgar. O método 6: ética. Tradução de J. M. da Silva. 2. ed. Porto Alegre: Sulina, 2005.

MOTTA, Flávia de Mattos. Velha é a vovozinha: identidade feminina na velhice. Santa Cruz do Sul: Edunisc, 1998.

NARDI, Henrique Caetano. O Ethos Masculino e o Adoecimento Relacionado ao Trabalho. In: DUARTE, Luiz Fernando Dias; LEAL, Ondina Fachel (Org.). Doença, sofrimento, perturbação: perspectivas etnográficas. Rio de Janeiro: Fiocruz, 1998. p. $95-104$.

NUNES, Carla Cafarate; AMADOR, Tânia Alves; HEINECK, Isabela. O medicamento na rotina de trabalho dos agentes comunitários de saúde da Unidade Básica de Saúde Santa Cecília, em Porto Alegre, RS, Brasil. Saúde e Sociedade, São Paulo, v. 17, n. 1, p.85-94, jan./mar. 2008.

OLIVEIRA, Elda Rizzo de. Representações sociais sobre doenças: os magos da ciência e os cientistas da magia. In: BOTAZZO, Carlos; FREITAS, Sérgio Fernando Torres de (Org.). Ciências sociais e saúde bucal: questões e perspectivas. Bauru, SP: EDUSC/ São Paulo: Fundação Editora da UNESP, 1998a. p. 43-85. 
OLIVEIRA, Roberto Cardoso de. O trabalho do antropólogo. São Paulo: Unesp/ Brasília: Paralelo 15, 1998b. p. 17-35.

OLIVEIRA, Pedro Paulo. A construção social da masculinidade. Belo Horizonte: UFMG/ Rio de Janeiro: IUPERJ, 2004.

PECHMAN, Robet Moses. A Invenção do urbano: a construção da ordem na cidade. In: PIQUET, Roselia; RIBEIRO, Ana Clara Torres (Org.). Brasil Território da desigualdade. Rio de Janeiro: Jorge Zahar/FUJB, 1991. p. 123-131.

PEIRANO, Mariza. A favor da etnografia. In: PEIRANO, Mariza. A favor da etnografia. Rio de Janeiro: Relume Dumará, 1995. p.31-57.

PERROT, Michelle. As mulheres, o poder, a história. In: PERROT, Michelle. Os excluídos da história: operários, mulheres e prisioneiros. Rio de Janeiro: Paz e terra, 1988. p. 165-231.

PERROT, Michelle. Minha história das mulheres. São Paulo: Contexto, 2007.

PICCOLO, Fernanda Delvalhas. A gramática nativa: reflexões sobre as categorias morro, rua, comunidade e favela. In: FRÚGOLI JÚNIOR, Heitor, ANDRADE, Luciana Teixeira de; PEIXOTO, Fernanda Arêas (Org.). As cidades e seus agentes: práticas e representações. Belo Horizonte: PUC Minas/ São Paulo: Edusp, 2006. p.330-352.

PIGNARRE, Philippe. O que é medicamento?: um objeto estranho entre ciência, mercado e sociedade. Tradução de P. Neves. São Paulo: Ed. 34, 1999.

PIGNARRE, Philipe. La depresión: una epidemia de nuestro tiempo. Traducción de R. P. Moré. Barcelona: DEBATE, 2003.

PIRES, Julio Manuel. O Desenvolvimento econômico de Ribeirão Preto: 19302000. Associação Comercial e Industrial de Ribeirão Preto: Um espelho de 100 anos. Ribeirão Preto: Gráfica São Francisco, 2004. p.179-191.

PORTER, Roy. História do corpo. In: BURKE, Peter (Org.). A escrita da história: novas perspectivas. Tradução de M. Lopes. São Paulo: Unesp, 1992. p. 291-326.

POURCHET-CAMPOS, Maria Aparecida. Perfil do ensino farmacêutico no Brasil. Rio de Janeiro: Ministério da Educação e Cultura, 1966.

QUARTAROLI, Carlos Fernando; MIRANDA, Evaristo Eduardo de; VALLADARES, Gustavo de Souza; HOTT, Marcos Cicarini; CRISCUOLO, Cristina; GUIMARÃES, Marcelo. Avaliação da adequação do uso de terras 
agrícolas no Nordeste do Estado de São Paulo em 1988 e 2003. Documento N. 57. Campinas: Embrapa Monitoramento por Satélite, 2006. 36p.

QUEIROZ, Marcos S. Farmacêuticos e médicos: um enfoque antropológico sobre o campo de prestação de serviços de saúde em Paulínea. In: ALVES, Paulo César; MINAYO, Maria Cecilia de Souza. Saúde e doença: um olhar antropológico. Rio de Janeiro: Fiocruz, 1994. p. 153-166.

QUEIROZ, Maria Isaura Pereira de. Variações sobre a técnica de gravador no registro da informação viva. $2^{a}$ ed. São Paulo: CERU/FFLCH-USP, 1983.

RABASQUINHO, Cidália; PEREIRA, Henrique. Género e saúde mental: uma abordagem epidemiológica. Análise Psicológica, Lisboa, v. 25, n. 3, p. 439-454, 2007.

RABELO, Miriam Cristina; ALVES, Paulo César. Corpo, experiência e cultura. In: LEIBING, Annette (Org.). Tecnologias do corpo: uma antropologia das medicinas no Brasil. Rio de Janeiro: NAU Editora, 2004. p. 175-200.

RAGO, Margareth. Do cabaré ao lar: a utopia da cidade disciplinar: Brasil 18901930. Rio de Janeiro: Paz e Terra, 1985.

REY, Fernando González. Pesquisa qualitativa e subjetividade: os processos de construção da informação. Tradução de M. A. F. Silva. São Paulo: Pioneira Thomson Learning, 2005.

ROMANELLI, Geraldo. A entrevista antropológica: troca e alteridade. In: ROMANELLI, Geraldo; ALVES, Zélia Maria Mendes Biasoli (Org.). Diálogos metodológicos sobre prática de pesquisa. Ribeirão Preto: Legis Summa, 1998. p. 119-133.

SANTOS, Milton. O espaço dividido: os dois circuítos da economia urbana dos paiíses subdesenvolvidos. Tradução de M. T. R. Viana. 2. ed. São Paulo: Edusp, 2004.

SARTI, Cynthia Andersen. A família como espelho: estudo sobre a moral dos pobres. 2. ed. São Paulo: Cortez, 2003.

SCHRAIBER, Lilia B. Violência contra as mulheres e políticas de saúde no Brasil: o que podem fazer os serviços de saúde? Revista USP, v. 51, p. 104-113, 2001.

SCHRAIBER, Lilia B.; OLIVEIRA, Ana Flávia Pires de. Violência contra mulheres: interfaces com a saúde. Interface - Comunicação, Saúde, Educação, v.3, n. 5, p.11-25, 1999. 
SENNET, Richard. Corrosão do caráter: consequências pessoais do trabalho no novo capitalismo. Tradução de M. Santarrita. Rio de Janeiro: Record, 2004.

SEVALHO, Gil. O medicamento percebido como objeto híbrido: uma visão crítica do uso racional. In: ACURCIO, Francisco de Assis (Org.). Medicamentos e Assistência Farmacêutica. Belo Horizonte: COOPMED, 2003. p. 1-9.

SIBILIA, Paula. O homem pós-orgânico: corpo, subjetividade e tecnologias digitais. 2. ed. Rio de Janeiro: Relume Dumará, 2003.

SILVA, Maria Aparecida de Moraes. Errantes do fim do século. São Paulo: Unesp, 1999.

SILVA, Vagner Gonçalves da. O antropólogo e sua magia: trabalho de campo e texto etnográfico nas pesquisas antropológicas sobre religiões agro-brasileiras. 1. ed. 1. reimpressão. São Paulo: Edusp, 2000.

SILVA, Adriana Capretz Borges da. Campos Elíseos e Ipiranga: memórias do antigo Barração. Ribeirão Preto: Editora COC, 2006.

SIMMEL, Georg. A metrópole e a vida mental. Tradução de S. M. dos Reis. In: VELHO, Otávio Guilherme (Org.). O fenômeno urbano. Rio de Janeiro: Zahar Editores, 1976. p. 11-25.

SINGLY, François de. O nascimento do "indivíduo individualizado" e seus efeitos na vida conjugal e familiar. Tradução de C. E. Peixoto. In: PEIXOTO, Clarice Ehlers; SINGLY, François de; CICCHELLI, Vincenzo (Org.). Família e individualização. Rio de Janeiro: FGV, 2000, p. 13-19.

SOARES, Jussara Calmon Reis de Souza. Abordagens sócio-antropológicas na compreensão do uso dos medicamentos. Cadernos de Saúde Coletiva, Rio de Janeiro, v.5, n. 1, p.5-12, 1997.

SOIHET, Rachel. Mulheres pobres e violência no Brasil urbano. In: PRIORE, Mary Del (Org.); BASSANEZI, Carla (Coord.). História das mulheres no Brasil. 7. ed. São Paulo: Contexto/Unesp, 2004. p. 362-400.

SONTAG, Susan. Diante da dor dos outros. Tradução de Rubens Figueiredo. São Paulo: Companhia das Letras, 2003.

TAVARES, Sandra Maria Greger; ALBERTINI, Paulo. Moradia e corporeidade em espaços liminares: um estudo sobre formas de subjetividade na favela. Paidéia (Ribeirão Preto), v. 15, n. 31, p. 299-308, 2005. 
TESSER, Charles Dalcanale. A verdade na biomedicina, reações adversas e efeitos colaterais: uma reflexão introdutória. Physis: Revista de Saúde Coletiva, Rio de Janeiro, v.17, n. 3, p.465-484, 2007.

THIOLLENT, Michel J. M. A falsa neutralidade das enquetes sociológicas. In: THIOLLENT, Michel J. M. A. Crítica metodológica, investigação social e enquete operária. 2. ed. São Paulo: editora Polis, 1981. p. 41-77.

THOMPSON, Edward Palmer. A venda de esposas. In: THOMPSON, Edward Palmer. Costumes em comum. Tradução de R. Eichemberg. São Paulo: Companhia das Letras, 1998. p. 305-352.

TURNER, Victor W. Liminaridade e "Communitas". In: TURNER, Victor W. O processo ritual: estrutura e anti-estrutura. Tradução de N. C. de Castro. Petrópolis: Vozes, 1974. p. 116-159.

VELHO, Gilberto. O estudo do comportamento desviante: a contribuição da Antropologia Social. In: VELHO, Gilberto. Desvio e divergência. Uma crítica da patologia social. Rio de Janeiro: Zahar Editores, 1974. p. 11-28.

VELHO, Gilberto. Individualismo e cultura: notas para uma antropologia da sociedade contemporânea. $4^{\mathrm{a}}$ ed. Rio de Janeiro: Jorge Zahar Editor, 1997.

VIANA, Larissa. O idioma da mestiçagem: as irmandades de pardos na América Portuguesa. Campinas: Unicamp, 2007.

VÍCTORA, Ceres Gomes; KNAUTH, Daniela Riva; HASSEN, Maria de Nazareth. Pesquisa qualitativa em saúde: uma introdução ao tema. Porto Alegre: Tomo Editorial, 2000.

VUCKVOVI, Nancy; NICHTER, Mark. Agenda for an anthropology of pharmaceutical practice. Social Science and Medicine. v. 39, n. 11, p. 1509-1525, 1994.

VAND DER GEEST, Sjaak; WHYTE, Susan Reynolds; HARDON, Anita. The anthropology of pharmaceuticals: a biographical approach. Annual Review of Anthropology, v. 25, p. 153-158, oct. 1996.

VAN DER GEEST, Sjaak; WHYTE, Susan Reynolds. Popularité et scepticisme: opinions contrastées sur les médicaments. Anthropologie et sociétés, Québec, v. 27, n.2, p. 97-117, sept. 2003.

WACQUANT, Loïc. Que é gueto? Construindo um conceito sociológico. Revista de Sociologia e Política, Curitiba, n. 23, p.155-164, nov. 2004. 


\section{Anexo 1 - Termo de Consentimento Livre e Esclarecido²}

O (a) senhor(a) está sendo convidada a participar de uma pesquisa que tem como título "Concepções sobre medicamentos psicoativos: relacionando gênero, curso de vida e itinerário terapêutico", tendo como objetivo interpretar os significados do uso de calmantes e antidepressivos alopáticos no decorrer de sua vida, na história de sua vida, nos acontecimentos da sua vida cotidiana, no dia-a-dia, desde o seu nascimento. Convidamos-lhe a nos conceder entrevista(s) onde a (o) senhor(a) relatará os acontecimentos de sua vida, envolvendo calmantes ou antidepressivos alopáticos ou que a (o) senhor(a) suponha que seria necessário o seu consumo. E caso seja seu desejo interromper a entrevista, podemos agendar outro encontro para que possamos dar continuidade a entrevista para colher sua história de vida, sendo o horário o mais conveniente. Suas respostas, junto com a dos outros participantes do estudo, poderão ajudar profisssionais a desempenhar melhor sua função, a compreender o atual consumo desses medicamentos. Solicitamos também permissão para analisar e utilizar dados de seus prontuários médicos na pesquisa, assim como para estudar os tratamentos medicamentosos e o contexto em que é consumido (por exemplo, sua casa, os serviços de saúde, o bairro), e para obter imagens fotográficas destes ambientes e do (a) senhor(a), sempre preservando sigilo com relação a sua identidade e sua privacidade.

Se a (o) senhora(o) concordar com essas condições, por favor assine este termo de consentimento e receberá uma cópia do mesmo. Declaro também que:

\footnotetext{
${ }^{2}$ Termo entregue e lido pelo entrevistador ao possível participante antes do início da entrevista, sendo uma cópia concedida à mesma.
} 
1) Estou aceitando voluntariamente a participação nesse projeto, não tendo sofrido nenhuma forma de pressão para isso.

2) Posso deixar de participar do projeto, a qualquer momento, caso eu desejar.

3) Fui assegurada de que minhas informações e os registros das entrevistas serão utilizados somente para estudo do referido projeto e de forma a não me identificar, mantendo sigilo, confidencialidade, assim como minha privacidade.

4) Fui informada de que não correrei nenhum risco decorrente da pesquisa por não se aplicar procedimentos invasivos.

5) Se desejar, posso ter acesso às informações desse estudo.

6) Fui informada de que não terei nenhum beneficio decorrente da participação na pesquisa.

7) Declaro que, após convenientemente esclarecido pelo pesquisador e ter entendido o que me foi explicado, consinto em participar desta Pesquisa.

Minha aceitação significa que estou ciente de que estarei respondendo à entrevista com história de vida a ser conduzida pelo pesquisador do referido projeto, e tenho ciência de que as entrevistas serão gravadas.

$\mathrm{Eu}$ ,RG ,aceito participar do projeto: “Concepções sobre medicamentos psicoativos: relacionando gênero, curso de vida e itinerário terapêutico" a ser desenvolvido por Reginaldo Teixeira Mendonça, doutorando em Saúde Pública pela Faculdade de Saúde Pública da Universidade de São Paulo (FSP - USP) no Programa de Pós-Graduação em Saúde Materno-Infantil.

Ribeirão Preto, , de de 
$\mathrm{Eu}$, Reginaldo Teixeira Mendonça, RG 3281202 SSPGO, como pesquisador responsável, declaro que estarei respeitando todos os termos supra-mencionados na realização do projeto de pesquisa em questão, objeto de estudo de doutorado com duração de 4 anos, por verdade firmo.

Ribeirão Preto, , de de

Dados para contato em caso de quaisquer esclarecimentos.

Pesquisador Reginaldo Teixeira Mendonça

Orientador: Prof. Dr. Rubens de Camargo Ferreira Adorno

Telefones: Ribeirão Preto (16) 30112551; São Paulo: (11) 3066-7703

Faculdade de Saúde Pública USP

Av. Dr. Arnaldo, 715 - Cerqueira César

CEP: 01246-904 São Paulo/ SP

E-mail: $\underline{\text { rtm@usp.br }}$ 


\section{Anexo 2 - Ofício de aprovação do projeto de pesquisa pelo Comitê de Ética em Pequisa da FSP/USP}

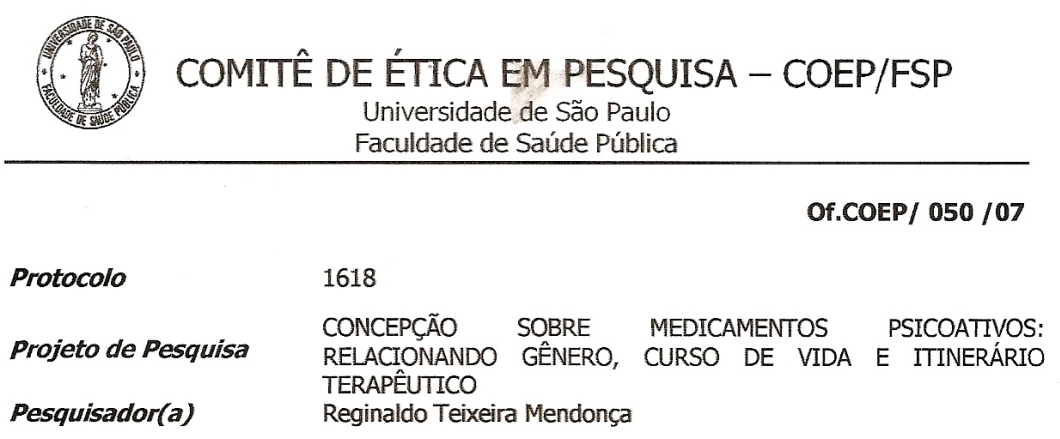

20 de ABRIL de 2007.

Prezado(a) Orientador(a),

O Comitê de Ética em Pesquisa da Faculdade de Saúde Pública da Universidade de São Paulo - COEP analisou, em sua 2. a/07 Sessão Ordinária, realizada em 13.04.07, de acordo com os requisitos da Resolução CNS/196/96 e suas complementares, o protocolo de pesquisa acima intitulado, e o considerou APROVADO.

Lembramos, ainda, que conforme Resolução CNS/196/96 são deveres do(a) pesquisador(a):

1. Comunicar, de imediato, qualquer alteração no projeto e aguardar manifestação deste CEP (Comitê de Ética em Pesquisa), para dar continuidade à pesquisa;

2. Manter sob sua guarda e em local seguro, pelo prazo de 5 (cinco) anos; os dados da pesquisa, contendo fichas individuais e todos os demais documentos recomendados pelo CEP, no caso eventual auditoria;

3. Comunicar, formalmente a este Comitê, quando do encerramento deste projeto;

4. Elaborar e apresentar relatórios parciais e finais;

5. Justificar, perante 0 CEP, interrupção do projeto ou a não publicação dos resultados.

Atenciosamente,

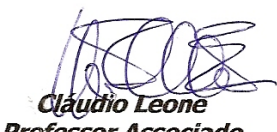

Professor Associado

Coordenador do Comitê de Ética em Pesquisa - FSP/COEP

Ilm. Sr.

Prof. Dr. Rubens de Camargo Ferreira Adorno

Departamento de Saúde Materno-Infantil

Av. Dr. Arnaldo, 715 - Assessoria Acadêmica - CEP: 01246-904 - São Paulo - SP Telefones: (55-11) 3061-7779/7742 e-mail: coep@ísD.usp.br site www.fsp.usp.b 


\section{Anexo 3 - Ofício de aprovação do projeto de pesquisa pelo Comitê de Ética em Pequisa do CSE-FMRP-USP}

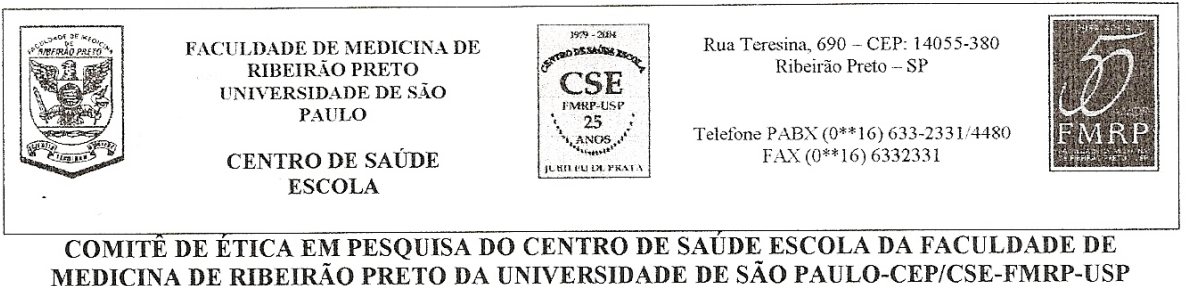

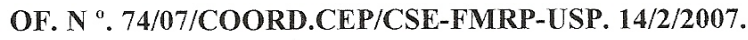

Senhor Professor,

Vimos na presente oportunidade comunicar que o Comitê de Ética em Pesquisa do Centro de Saúde Escola da Faculdade de Medicina de Ribeirão Preto da Universidade de São Paulo, em sua 56ª reunião ordinária, realizada em 13 de fevereiro de 2007, analisou e apreciou o parecer do Senhor Relator, referente ao Projeto de Pesquisa: "Concepção sobre medicamentos psicoativos: relacionando gênero, curso de vida e itinerário terapêutico". Protocolo:0213/CEP/CSE-FMRP-USP, que tem como pesquisador principal o

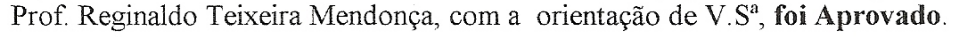

Lembramos que em atendimento à Resolução 196/96, deverá ser encaminhado a este CEP o relatório final da pesquisa e a publicação de seus resultados.

No ensejo, renovamos os votos de elevada estima e consideração.

Despedimo-nos

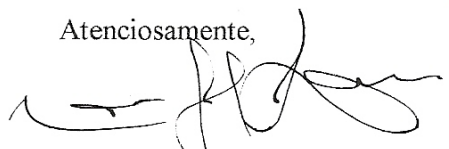

Prof. Dr. Laércio Yoel Franco

Coordenador do CEP/CSE-FMRP-USP

Ilmo. Sr.

Prof. Dr. Rubens de Camargo Ferreira Adorno

Faculdade de Saúde Pública da USP. 


\section{CURRÍCULO LATTES - Doutorando}

Currículo do Sistema de Currículos Lattes (Reginaldo Teixeira Mendonça)

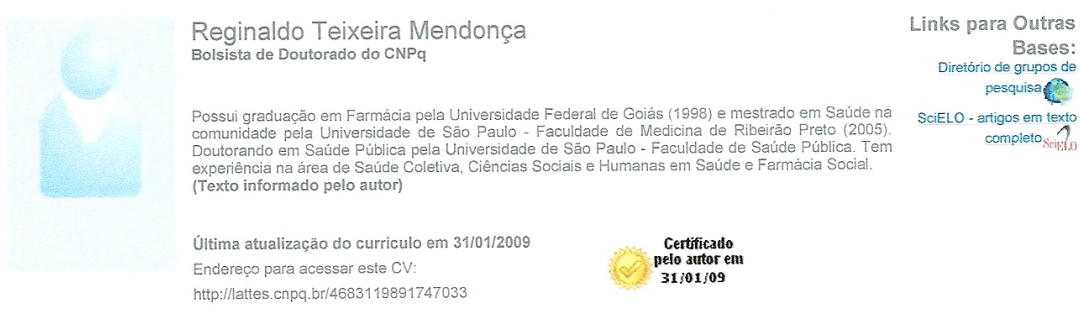

Dados pessoais

Nome Reginaldo Teixeira Mendonça

Nome em citaçäes MENDONÇA, R. T.Mendonça, Reginaldo Teixeir

bibliográficas

Sexo Masculino

Formaçăo acadêmicalTitulação

2006 Doutorado em Saúde Pública.

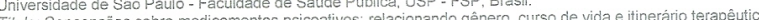

Titulo: Concepcós sobror: Rubens de Carmargo Ferreira Adorno.

Bolsista do(a): Conselho Nacional de Desenvolvimento Cientifico e Tecnolágico,

Grande érea: Ciências da Saudce / Area: Saúde Coletiva.

2003 - 2005 Mestrado em Saude na comunicade.

Universidade de Säo Paulo - Faculdade de Medicina de Ribeirăo Preto.

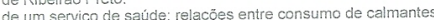

fio, Ano de Obtençäo: 2005

(4) Antorio Carios Duarie de Carvalho

Grande área: Ciências da Saúde / Area: Saúde Coletiva.
Grande ârea: Clências da Saúde / Area: Farmácia / Subárea: Farmácia Socia.

1999 - 1999 Especializacãa em Saúde Pública. (Carga Horária: 820h)

1995 - 1999 Graduaçăo em Farmácia. Universidade Federal de Goiás, UFG, Brasi

Formaçăo complementa

2006 - 2006 Extensão universitária em A cidade como fonte de pesquisa lll. (Carga horária: 18h)

2006 - 2006 Métodos de Pesquisa e Problemas de Saúde. (Carga horária: 40h)

2006 - 2006 Resolucão RDC n. 306: Gerenciamento de Resíduos.
Conselho Regional de Farmácia do Estado de Goiès.

2005 - 2005 Introduçăo à Arteterapia.

2005 - 2005 O sujeilo do discurso nas malhas do digital. (Carga horária: 120h).

Atuaçäo profilssiona

Universidade de São Paulo, USP, Brasil.

Vinculo institucional

2006 - Atual Vínculo: Doutorando, Enquadramento Funcional: Doutorando, Regime: Dedicaçăo exclusiva

Atividades

03/2006 - Atual Atividades de Participaçăo em Projeto, Faculdade de Saúde Publica, .

Projetos de pesquisa
Concepcóes sobre medicamentos psicoativos: relacionando gênero, curso de vida e itinerário terapêutico

02/2006 - Atual Pesquisa e desenvolvimento, Faculdade de Saúde Publica

Linhas de pes

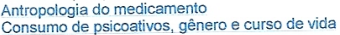

$11 / 2006$ - 11/2006 Outras atividades técnico-cientificas, $14^{\circ}$ SIICUSP - Simpósio Internacional de Iniciaçăo Científica

http://buscatextual.cnpq.br/buscatextual/visualizacv.jsp?id=E8351631

$8 / 4 / 2009$ 


\section{CURRÍCULO LATTES - Orientador}

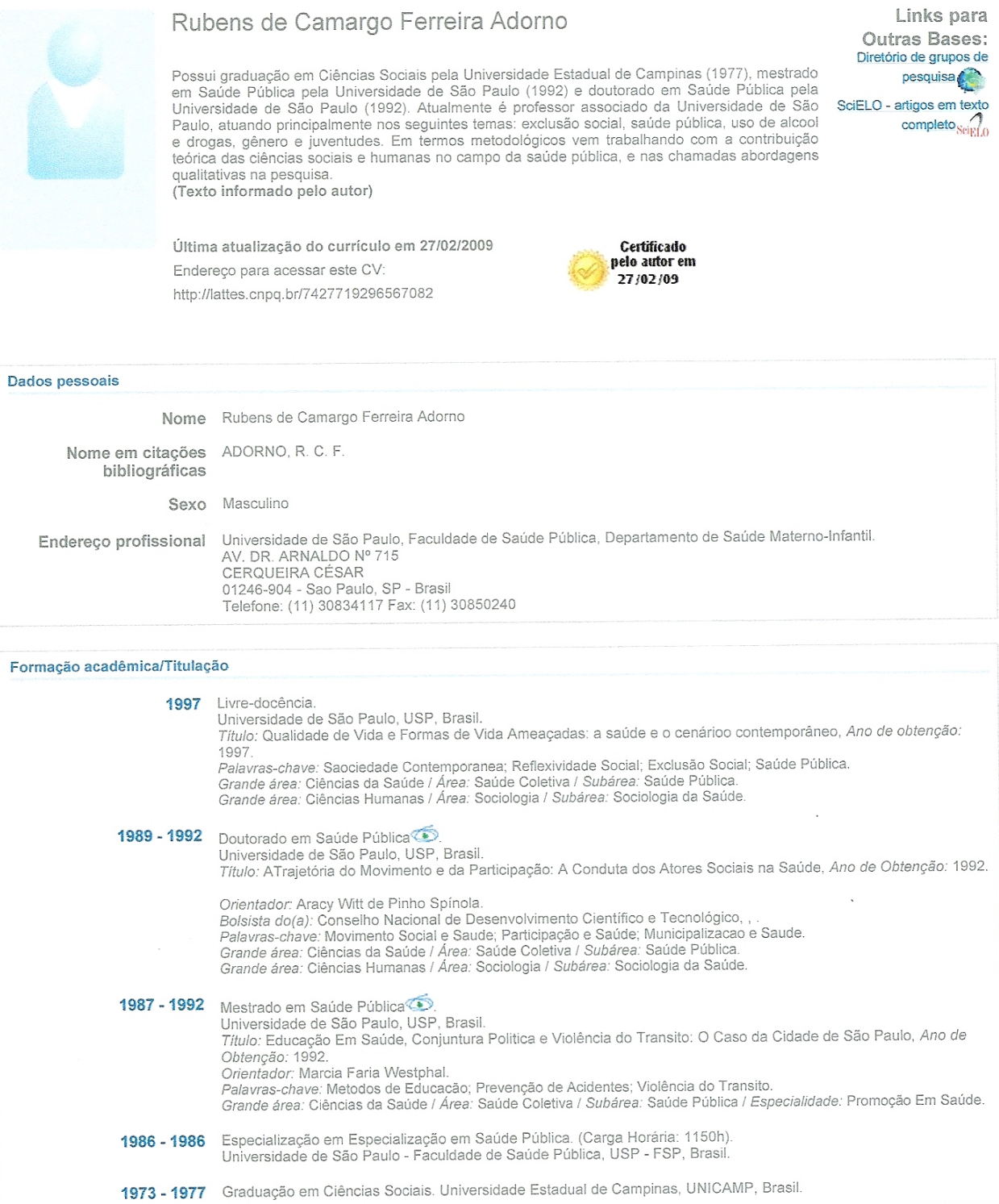

Dados pessoais

Nome Rubens de Camargo Ferreira Adorno

Nome em citaçöes ADORNO, R. C.F.

bibliográficas

Sexo Masculino

Endereço profissional Universidade de São Paulo, Faculdade de Saúde Pública, Departamento de Saúde Materno-Infanti.

AV. DR. ARNALDO No 71

CERQUEIRA CESAR

01246-904 - Sao Paulo, SP - Brasil
Telefone: (11) 30834117 Fax: (11) 30850240

Formação acadêmica/Titulação

1997 Livre-docência.

Universidade de Säo Paulo, USP, Brasil

Thlo Oulidade do Vido formas de Vida Ameaçadas a saúde e o cenárioo contemporâneo, Ano de obtenção: 1997.

Palavras-chave: Saociedade Contemporanea: Reflexividade Social; Exclusão Social; Saúde Pública Grande área: Ciências da Saúde / Área: Saúde Coletiva / Subárea: Saúde Pública.

1989 - 1992 Doutorado em Saúde Pública tos

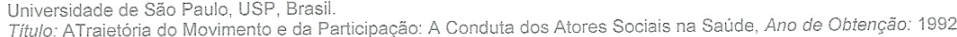

Miovimento e da Pari

Orientador: Aracy Witt de Pinho Spinola.

Bolsista do(a): Conselho Nacional de Desenvolvimento Científico e Tecnológico, , .

Grande área Ciências da Saúde / Área: Saúde Coletiva / Subárea Saúde Pública

Grande área: Ciências Humanas / Area: Sociologia / Subárea: Sociologia da Saúde.

1987 - 1992 Mestrado em Saúde Pública 6 .

Universidade de São Paulo, USP, Brasil.

Obtenção: 1992.

Orientador: Marcia Faria Westphal.

Palavras-chave: Metodos de Educacäo; Prevençăo de Acidentes, Violência do Transito.

1986 - 1986 Especializaçăo em Especialização em Saúde Pública. (Carga Horária: 1150h).

1973 -1977 Graduação em Ciências Sociais. Universidade Estadual de Campinas, UNICAMP, Brasil.

\section{Atuaçäo profissional}

Universidade de São Paulo, USP, Brasil.

Vinculo institucional

1985 - Atual Vinculo: Servidor Público, Enquadramento Funcional: PROFESSOR ASSOCIADO, Carga horária: 40, Regime: Dedicação exclusiva.

Atividades

$11 / 2007$ - Atual Atividades de Participação em Projeto, Faculdade de Saúde Pública

Projetos de pesquisa

Desenvolvimento de açöes de emponderamento de lideranças das populações em situaçăo de rua na cidade de São Paulo. 